$\Delta i x \eta$

A MÁRKus DEZső

ÖSSZEHASONLÍTÓ JOGTÖRTÉNETI KUTATÓCSOPORT FOLYÓIRATA

\section{A TARTALOMBÓL}

Az európai jogi kultúra közös értékei

Az európai jogi kultúra zsidó-keresztény gyökerei

Szakrális kontra szekuláris értékek a polgári modernizáció korában

„Újabb időkben sok magyar utazik a mívelt külföldön”. Politikai-társadalmi útirajzok a 19. század első feléből

Kulturális diverzitás és/vagy közösségi integritás?

Zsidó és dunai-sváb házassági szerződések a dualizmus-kori Magyarországon

Aki megment egy életet: Az örökbefogadás az osztrák és magyar magánjog rendszerében

A pedagógia egyetemi tudománnyá válása Ausztriában és Magyarországon

Az 1868. évi népoktatási törvény egyházi iskolákkal kapcsolatos rendelkezéseinek végrehajtása

Baranyában

A Jászkun szabadság
Az európai jogi kultúra közös értékei Tudományos ülés

Pécs, 2017. április 27.

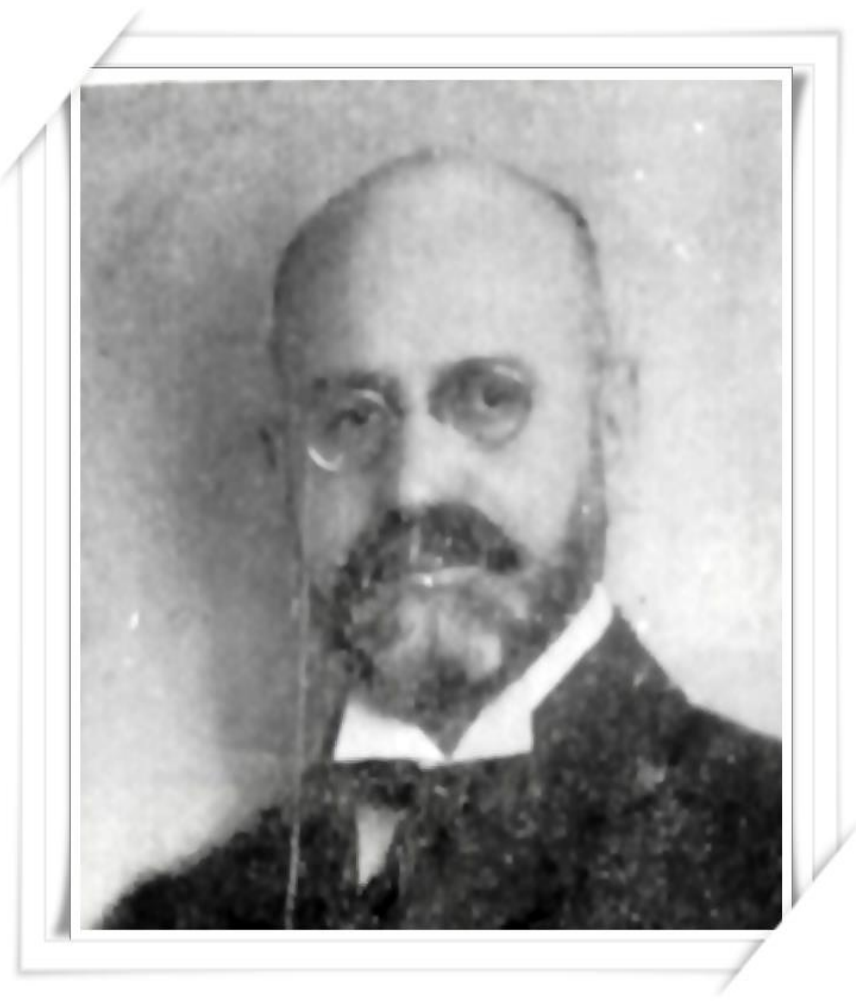




\title{
TARTALOM
}

\section{BEVEZETŐ}

Herger Csabáné: Az európai jogi kultúra közös értékei. A Márkus Dezső Összehasonlító Jogtörténeti Kutatócsoport tudományos ülésének megnyitójára (Pécs, 2017. április 27.)

\section{TANULMÁNYOK}

HACK Márta: Az európai jogi kultúra zsidó-keresztény gyökerei

HERGER Csabáné: Szakrális kontra szekuláris értékek a polgári modernizáció korában

SCHWEITZER Gábor: „Újabb időkben sok magyar utazik a mívelt külföldön”.

Politikai-társadalmi útirajzok a 19. század első feléből

NAGY Janka Teodóra: Kulturális diverzitás és/vagy közösségi integritás?

Nemzetiségek, népcsoportok és jogi kultúrák egymás mellett élése Bonyhádon

(18. század vége - 20. század közepe)

VIHART Ágnes: Zsidó és dunai-sváb házassági szerződések a dualizmus-kori Magyarországon

RÉKASINÉ ADAMKÓ Adrienn: Aki megment egy életet: Az örökbefogadás az osztrák és magyar magánjog rendszerében

DÁviD Gabriella: A pedagógia egyetemi tudománnyá válása Ausztriában és Magyarországon

NikLAi Patrícia Dominika: Az 1868. évi népoktatási törvény egyházi iskolákkal kapcsolatos rendelkezéseinek végrehajtása Baranyában

\section{ISMERTETÉS}

VINCZE Fanny Rose: A Jászkun szabadság. A törvényesség helyi sajátosságai a Jászkun kerület népi kultúrájában $(1682-1876)$

\section{$\Delta i x \eta$ \\ A MÁrKus DEZső \\ ÖsSZEHASONLÍTÓ JOGTÖRTÉNETI KUTATÓCSOPORT FOLYÓIRATA}

\author{
SZERKESZTŐ: HERGER Csabáné - SCHWEITZER Gábor \\ SZERKESZTŐBIZOTTSÁG: ÁdÁM Antal (Pécs) - KAjTÁr István (Pécs) - STEPPAN, Markus \\ (Graz) - STIPTA István (Budapest - Szeged) \\ A SZERKESZTŐSÉG CÍME: 7622 Pécs 48-as tér 1.
}

Kiadó: Pécsi Tudományegyetem Állam- és Jogtudományi Kar

Felelős kiadó: KECSKÉS László dékán

ISSN 2631-1232

DOI: 10.15170/DIKE.2017.01.01

A mú szerzői jogilag védett.

Minden jog, így különösen a sokszorosítás, terjesztés és fordítás joga fenntartva. 
Herger Csabáné

DOI: 10.15170/DIKE.2017.01.01.01

habilitált egyetemi docens

PTE ÁJK

\title{
Az európai jogi kultúra közös értékei
}

\author{
A Márkus Dezső Összehasonlító Jogtörténeti Kutatócsoport \\ tudományos ülésének megnyitójára (Pécs, 2017. április 27.)
}

\section{A kutatócsoport alapításáról}

A Márkus Dezső Összehasonlító Jogtörténeti Kutatócsoport ${ }^{1}$ alapításának terve 2016 nyarán abból a felismerésből következően vetődött fel, hogy a történeti jogösszehasonlításra a hazai jogtörténettudományban számottevően kevesebb figyelem irányult, mint a nemzeti jogfejlődésre. Az elmúlt több mint két évtizedben a közép-európai térségből számos olyan jogtörténésszel kerültem munkakapcsolatba, akik a kutatási korszak és a vizsgált jogterületek illetve jogintézmények tekintetében közel állnak egymáshoz. A közös projektek és a rendszeres párbeszéd során bebizonyosodott, hogy a hazai alkotmány- és jogfejlődés számos elemét lehetséges és érdemes azokkal az eredményekkel összehasonlítani, melyekre a régió jogtörténészei saját hazájuk alkotmány- és jogfejlődése vizsgálatakor jutottak.

A közös kutatócsoport alapítására irányuló kezdeményezést Markus Steppan, a grazi Karl Franzens Egyetem Jogtudományi Alapok Intézete Jogtörténeti és Európai Összehasonlító Jogi Tanszéke egyetemi tanára, Thomas Olechowski, a Bécsi Egyetem Jog- és Alkotmánytörténeti Intézete Osztrák Egyházjog-történeti Tanszéke egyetemi tanára, Andrzej Driadzৃio, a krakkói Jagello Egyetem Állam- és Jogtörténeti Tanszékének egyetemi tanára valamint Jaromír Tauchen, a brnoi Masaryk Egyetem Jog- és Államtörténeti Tanszékének egyetemi docense örömmel fogadta. Miután Markus Steppan közremúködésével elkészült a tervbe vett kutatócsoport magyar és német nyelvű alapító okirata, majd a Pécsi Tudományegyetem Állam- és Jogtudományi Kara Kari Tanácsa 2017 szeptemberében azt elfogadta, a Márkus Dezső Összehasonlító Jogtörténeti Kutatócsoport megalapítása a kar szervezeti egységeként, magyar tagokkal és külföldi együttműködő partnerekkel megtörtént.

A kutatócsoport célkitǔzése az, hogy nemzetközi kutatói együttmúködés keretében az európai jogfejlődés közös gyökereit és értékeit összehasonlító jogtörténeti módszerrel feltárja, valamint bemutassa, hogy mi az a közös alap, amelyre az európai jog alapulhat. A kutatócsoport figyelme különösen az európai jogi kultúra vallási és szekuláris értékeire, az állami jogérvényesítésre, az állam és az egyház közötti kapcsolatrendszer részterületeire, a jogátvétel - modellkövetés európai szellemú jogalkotás kérdéskörére valamint az európai családjog egyes intézményeire irányul.

\footnotetext{
${ }^{1}$ A kutatócsoport honlapját lásd md.ajk.pte.hu
} 
A 2017. április 27-i tudományos ülést, amely a kutatócsoport alapítása óta eltelt időszakban az idegen nyelvű, jogösszehasonlító tudományos rendezvények mellett az első magyar nyelvű szakmai fórum volt, ennek a célkitűzésnek a jegyében, az európai jogi kultúra közös értékei vizsgálatára hívtuk életre.

\section{A hangyaszorgalmú tudós mester}

Kutatócsoportunk névadója, Márkus Dęső́(Paks, 1862 - Budapest, 1912), a dualizmus-kori magyar jogtudomány neves képviselője, akinek tanulmányai, kézikönyvei és a szerkesztésében megjelent művek egyaránt nagy haszonnal forgathatók a polgári modernizáció korszakára vonatkozó összehasonlító jogtörténeti kutatásokhoz. Márkus mintegy ötvenévnyi, ijesztően rövid élete és huszonöt évnyi tudományos pályafutása egyben a korszak hû lenyomatát is adta. A hangyaszorgalmú tudós mestert, ahogy tanítványa Meszlény Artur nevezte², visszafogott, szerény emberként ismerték, és ezt tükrözi minden hivalkodást nélkülöző fekete márvány síroszlopa is a budapesti Kozmai utcai izraelita temetőben. Ha az oral history a 19. század második felének tudományos műfajai közé tartozott volna, egy Márkus Dęsốvel készített interjú méltán szerepelhetett volna a korszak főbb társadalomtörténeti jelenségeivel foglalkozó kötetben is.

Születésének évében a - neoabszolutizmus korának erőszakos osztrák jogexportját követően - már megtörtént a (részleges) visszatérés a magyar joghoz, de ugyanakkor megmutatkozott az a hiány is, ami a magyar büntetőjog és magánjog kodifikálatlan voltából, a jogegység és a kellő mértékű jogi modernizáció hiányából fakadt. Márkus, aki a Budapesti Tudományegyetemen 1885-ben szerzett jogi doktorátust, ezekre a kihívásokra a maga eszközeivel reagált ügyvédként, az ún. Ügyvédvizsgáló Bizottság tagjaként, a X. Magyar Jogászgyúlés jegyzőjeként (1889), előbb a Budapesti Ügyvédi Kör, majd az Országos Bírói és Ügyészi Egyesület tikáraként és ez utóbbi hivatalos lapjának szerkesztőjeként, majd 1894-től beosztott bíróként az Igazságügyminisztérium Törvényelőkészítő Osztályán, 1911-től pedig curiai bíróiként is. ${ }^{3}$

A maga korában is a legtermékenyebb és legérdemesebb magyar jogi szakírók egyikeként tartották számon. Munkássága, ahogy ez a 19. század második felében még rendszerint előfordult, több jogágra, sőt kifejezetten jogtörténeti kutatásokra és a jogi enciklopédia ügyére is kiterjedt. Élénken foglalkoztatta a gyöngék és az elnyomottak jogi védelmének kérdése, ezért rendszeresen adott elő és publikált szociális témákban (a törvénytelen gyermek jogállása, nőkérdés, munkáskérdés) illetve az előítéletek leküzdéséről is írt. Érdeklődése az élet valódi szükségletei iránt, biztos ítélőképessége és meleg szíve fogékonnyá tette a szükségek irányába, ezért a haladás és a művelődés érdekében gyakran vállalt társadalmi feladatokat is. Különösen foglalkoztatták a bírói és ügyvédi szervezeti kérdések, a polgári törvénykezési eljárás és a végrehajtás, a magánjog és a hiteljog, valamint a házassági jog kérdései, sôt a női jogegyenlőség biztosítása iráni küzdelem egyik élharcosa volt hazánkban. Ez utóbbi téma tekintetében említhető meg az is, hogy részt vett a polgári házasságról szóló 1894. évi XXXI. tc. általános indokolásának szerkesztésében, és számos előadást tartott a női jogokról illetve a törvénytelen származású gyermekek jogállásáról 1901-ben és 1909-

\footnotetext{
2 MESZLÉNY, Magyar magánjog I.

${ }^{3}$ SZINNYEI, Magyar írók VIII. köt. http://mek.oszk.hu/03600/03630/html/m/m15247.htm
} 
ben a Magyar Jogászegyletben valamint 1899-ben a gyermekvédő egyesület nemzetközi jogi konferenciáján. Ezeket a fellépéseit életrajzírója különösen nagyhatású reformakcióknak nevezte. ${ }^{4}$ Korai halála hírétől lesújtva a Jogtudományi Közlöny hasábjain 1912. december 6-án két megemlékezés jelent meg Márkus Dęsoôról. Barátja és közeli munkatársa, Fodor Ármin az eszmék kiváló harcosának, a kemény munka emberének nevezte: „Alig birom el a gondolatot, hogy ez az agy, amely a munkában oly lázasan müködött, hogy ez a kéz, amely pihenést nem ismerve egyik dolgozatot a másik után, egyik müvet a másik után vetette papirra, most élettelenül nyugszik. Jogász volt, akinek szük volt a jogtudomány területe. (...) Ismerte a magyar törvénytár minden zugát, mint senki más. És áttekintette a külföldi jogtudományt is, melynek nem egy eszuméjét ültette át hozzánk. (...) Tekintete túlhaladt a jogtudomány határain át az élet tág mezejére. Nagy, általános müveltsége és melegen érző" sqive vezérelték öt ebben. (...)Az emberiesség nevében hadat üzent a nézete szerint elavult eszméknek és jogszabályoknak."

A második megemlékező, Justus és a harmadik, név nélküli szerző Márkus tudományos műveiről adott áttekintést. Márkus kezdte meg a döntvényjog rendszeres feldolgozását a magyar jogirodalomban, de talán „még nagyobb érdeme a (bat kötetes) Jogi Lexikon, amelyben óriási munka árán sikerült a magyar jog minden terének alapvetö fogalmait összegyüjteni. Legnagyobb müve a Magyar Törvénytár. Minden jogirodalom biányos addig, amig a törvénytár a törvényhelyek egymásra való vonatkozása tekintetében nincs feldolgozva. A magyar jogirodalomban ily mü nem volt, mig Márkus nem fogott hozzá. (...) A törvényanyag egészén és emellett a legapróbb részleteken is uralkodnia kell annak, aki az ily munkát akarja jól végezni. Hogy maga ily munkát elópó forrásmunkák nélkül egymaga elvégezhessen, ahboz. a kivételes univerzális jogi tudáson kivül oly kivételes munkaerövel is kell rendelkęnie, ami kevésnek adatott. (...) Mint bírónak - folytatja a méltatást Justus - a azélettel való kapcsolat és a gyakorlati szüleségletek méltánylása volt az alapelve. A törvényt össz̧hangba hozni avval, amit az ember igazságnake érez, ezt vallotta az itélkezés fö créljának. És megvolt benne az, mai a biróban a legbecsesebb: meleg szív az igazságosság iránt és bátorság az initiativára és a sablontól való eltérésre."

Márkus Dęsố rövid életének a jogi doktorátus megszerzésétôl (1885) haláláig (1912) tartó szakaszában több mint negyven önálló írása és több mint száz kötete jelent meg. Cikkeit és tanulmányait 1886-tól a Jogtudományi Közlönyben, a Fôvárosi Lapokban, a Debreczeni királyi táblai Értesítőben, az Ügyvédek Lapjában, a Jogban, az Egyenlőségben s az általa 1889 és 1893 között szerkesztett Jogi Szemlében valamint a Budapesti Szemlében publikálta, de gyakran írt napilapokban is. Bár legnagyobb műveként a Magyar Törvénytár - Corpus Juris Hungarici millenniumi emlékkiadását tartják számon, melyet 1896-ban indított és haláláig egyedül szerkesztett illetve látott el magyarázatokkal és utalásokkal, a történeti jogösszehasonlítás szempontjából talán legértékesebbnek a „Magyar magánjog mai érvényében: törvények, rendeletek, szokásjog, joggyakorlat I-III” (Budapest: Grill, 1906) c. mûve valamint „Az osztrák Általános Polgári Törvénykönyv mai érvényében" (Budapest: Grill, 1907) c. műve tekinthető. Imling Konrád a Jogtudományi Közlöny hasábjain mégsem elsősorban ezekért, hanem polihisztori, társadalmi kérdések egész sorára kiterjedő szakírói tevékenységéért nevezte a haladás és a humanizmus előharczosának. ${ }^{7}$

\footnotetext{
${ }^{4}$ Justus, Márkus Dezső II. 424.

${ }^{5}$ Fodor, Márkus Dezső I. 423.

${ }^{6}$ Justus, Márkus Dezső II. 424.

${ }^{7}$ N. n., Márkus Dezső III., 424-425.
} 


\section{Hol kell keresnünk az európai jogi kultúra közös értékeit?}

Az európai jogi kultúra közös gyökereinek feltárása és bemutatása történeti jogösszehasonlítással valósítható meg. A történeti kutatás a 18-19. század fordulója óta elfogadott, sőt szükségesnek tekintett feltétele volt a jogtudomány filozófiai megalapozásának és a szerves jogfejlesztésnek. Bár a jogtudomány művelésének munkamódszereként - a vizsgálat konkrét tárgyától függetlenül elsőként a német történeti jogi iskola (Historische Rechtsschule) képviselői alkalmazták, a német jogtörténet atyjaként mégsem az iskolaalapítókat, így a romanista Carl Friedrich von Savignyt (17791861), a germanista Karl Friedrich Eichhornt (1781-1854) vagy társaik egyikét, hanem egy korai elődjüket, a humanista helmstedti polihisztort, Hermann Conringot tartják számon.

A 19. század korai évtizedeiben ugyanakkor már fontos szerephez jutott a jogösszehasonlítás is, többek között a kanti tanokat követő Paul Johann Anselm von Feuerbach (17751833) munkásságában, aki - az egyetemes, történeti szemléletétől eltávolodva - a hatályos jogok intézményeinek összevetésére helyezett hangsúlyt. Az előzmények a jogösszehasonlítás vonatkozásában sem hagyhatók figyelmen kívül. Ahogy az első, késő-antik jogösszehasonlító műnek tekintett „Collatio legum Mosaicarum et Romanarum” praktikus céloknak köszönhette megszületését az 5. század fordulóján, gyakorlati szempontokkal magyarázható az is, hogy egyes germán törzsi jogfeljegyzéseket a 9. századi Frank Birodalomban kisméretú kézikönyvekbe másolták be, hogy a ius personalis elvét alkalmazó bíró számára a szükséges joganyag mindig kéznél legyen. Ahogy később a glosszátorok és a kommentátorok a római jog, a germán jog és a kánonjog egyes tételeit összevetették, a gyakorlatiasság motiválta Feuerbachot is. A jogösszehasonlítás - az előzmények ellenére - mégis a romantika korának szülötte, és ez a program igen közel állt a nyugati bölcselet általános törekvéséhez, történeti világfelfogásunk formálódásának vizsgálatához. ${ }^{8}$

A történeti és az összehasonlító jogi vizsgálat együttes alkalmazására a 18. század utolsó évtizedeitôl már volt példa, a századforduló után pedig a jogi partikularizmus (római jogi és germán jogi, továbbá hűbéri jogi és egyházjogi intézmények és elvek egymás mellett élése illetve összefonódása) szükségszerû következményeként rendszeresen előforduló kutatási módszerré vált a német térségben, Franciaországban és az angolszász jog területén is.

Azt, hogy a 21. század második évtizedében is fontos szerepe lehet a történeti jogösszehasonlító kutatásoknak, könnyen igazolhatjuk a közelmúlt politikai eseményeivel is. Az Európai Gazdasági Közösség létrehozásáról szóló, 1957. március 25-én aláírt Római Szerződés hatvanadik évfordulójára számos ünnepséget szerveztek. A jubileumi rendezvényekhez kapcsolódik az Európai Unió 27 tagállama, az Európai Tanács, az Európai Parlament és az Európai Bizottság vezetőinek nyilatkozata, amelyet 2017. március 25-én írtak alá: a Római Nyilatkozat 4. bekezdésében az aláírók kijelentették, hogy „Együtt van a legjobb esélyünk arra, hogy (...) megvédjüle közös érdekeinket és értékeinket” a globális folyamatokkal szemben, melyek „egyenként báttérbe szorítanák országainkat'. A Nyilatkozatban megfogalmazott programpontok ${ }^{10}$ közvetett módon kifejeznek egy közös értékirányultságot, ahogy ezt tükrözi az 1. bekezdés utolsó mondata is: „Az Európai Unió

\footnotetext{
8 A téma kifejtését lásd HeRGER, A modern magyar házassági vagyonjog 19-34.

9 file:///rome_declaration_2017_hu.pdf

10 1. biztonságos és védett Európa; 2. virágzó és fenntartható Európa; 3. szociális Európa; 4. a nemzetközi porondon erőteljesebben fellépő Európa. Lásd file:///rome_declaration_2017_hu.pdf
} 
a békee, a szabadság, a demokrácia, az emberi jogok és a jogállamiság elvén alapuló közösség, valamint gazdasági nagyhatalom, amely a világon egyedülálló mértékü szociális védelmet és jólétet biżtosit." A Nyilatkozat azonban nem határoz meg konkrét értékeket és nem szól arról sem, hogy ezek a „szilárd értékeek” (lásd: 1. bekezdés 4. mondat) honnan származnak, miből vezethetők le.

Különösen annak fényében szembetűnő ez a hiányt, hogy - míg Európa egy nemzetek fölötti intézményrendszer fölépítésén fáradozik - állandósulni látszik a társadalmi vita: létezik-e egy az európaiakat meghatározó közös identitás vagy a nemzetek (jogi) kultúrája úgy illeszkedik csak egymáshoz, mint agyag a vashoz? Vannak-e az európai kultúrának közös gyökerei, és ha igen, akkor melyek ezek a közös gyökerek?

Rezsốbázy Rudolf, akinek az európai értékek eredetéről 2012 megjelent könyve a nagyobb belga könyvkereskedések közös kimutatása szerint ez év ôszén sokáig az eladási listák élén helyezkedett $\mathrm{el}^{11}$, egy interjú során kifejtette, hogy ez a vita azért vezet sok esetben éles konfliktushoz, mert a résztvevők ideológiáktól eltorzított nézeteket vallanak. Egyesek úgy vélekednek, hogy az európai értékek lényegét tekintve a felvilágosodás századában születtek meg, míg mások a bibliai alapú, zsidó-keresztény kultúra döntő szerepét húzzák alá. Mindeközben a nevesített értékek - legyen szó a kettő eszmerendszer bármelyikéről - rendszerint csupán egy kitűzött ideálra utalnak, melyeket a konkrét cselekvések gyakran cáfolnak, sőt az európaiak, ha objektíve léteznek is európai értékek, szubjektíve sok esetben nem vallják meg őket. ${ }^{12}$

Kutatócsoportunk 2017. április 27-i tudományos ülésén természetesen nem vállalkozhattunk arra, hogy az európai jogi kultúra közös gyökereit teljességében feltárjuk. Arra azonban kísérletet tettünk, hogy áttekintsük a zsidó-keresztény jogi kultúra értékszemléletét és az ebből fakadó alapelveket valamint a polgári modernizáció korában a modernizációs modellként szolgáló európai államok alkotmányos dokumentumainak értékeit. Foglalkoztunk - a magyar jogi kultúrára koncentrálva - az államalkotó nemzet valamint a nemzeti és etnikai kisebbségek egymás mellett élésének néhány elemével, melyek a polgári modernizáció korában és napjainkban is megkérdőjelezhetővé tették illetve teszik az ún. kulturális nemzetállam-felfogás érvényesülését, majd az „európai hatások - magyar reakciók” témakörben - a sok közül ezúttal csak párat nevesítve - olyan jogintézmények fejlődését vizsgáltuk, melyek esetében az európai hatások közvetlenül kimutathatók. Kutatócsoportunk folyóiratának 2017. évi 1. száma a tudományos ülésen elhangzott előadások írott változatát tartalmazza.

\section{Felhasznált irodalom}

FODOR Ármin: Márkus Dezső I. Jogtudományi Közlöny 1912/49. sz. 423-424.

HERGER Csabáné: A megélt kor. Egy 20. századi oral history Ádám Antal és Rezsőházy Rudolf életútja alapján. Pécs 2012

HERGER Csabáné: A modern magyar házassági vagyonjog kialakulása és rendszere az európai jogfejlődés tükrében. Passau 2017

Justus: Márkus Dezső II. Jogtudományi Közlöny 1912/49. sz. 424.

MESZLÉNY Artur: Magyar magánjog I. Személyi és családi jog. Budapest 1931

${ }^{11}$ Vö. REZSŐHÁZY, Émergence des valeurs 2-5.

${ }^{12}$ Herger, A megélt kor 93-109. 
N. N.: Márkus Dezső III. Jogtudományi Közlöny 1912/49. sz. 424-425.

REZSŐHÁZY Rudolf: Émergence des valeurs communes aux Européens á travers le temps. Paris 2012 SZINNYEI József: Magyar írók élete és munkái VIII. Budapest 1902

http://mek.oszk.hu/03600/03630/html/m/m15247.htm (letöltve: 2017. 12. 14.) 
HACK Márta

DOI: 10.15170/DiKE.2017.01.01.02

főiskolai docens, tanszékvezető

Szent Pál Akadémia Ókori nyelvek Tanszék

\section{Az európai jogi kultúra zsidó-keresztény gyökerei}

\section{Judeo-Christian Roots of the European Legal Culture}

This article deals with the Judeo-Christian roots of the European legal culture. The Torah or mosaic Law contains the basic principles of individual human rights, equality before the Law, rule of Law. The Ten Commandments as universal ethical norm is not only a catalogue of moral obligations, but it is a source of human liberties. The analysis of the Decalogue shows the toraic regulation that shaped our conceptions of the value of human life, family, education, property, dignity, privacy, judiciary system and good governance. This study makes an attempt to connect the Old Testament legislation and the western society through the reception of the New Testament in the European culture, to show how relevant are the toraic values still today.

Keywords: biblical anthropology, biblical principles of jurisdiction, inalienable buman rights, public good, rule of law, Ten Commandments, universal ethical norm

\section{Bevezetés}

Jelen írás arra keresi a választ, milyen bibliai elvek alakították az európai jogi kultúrát. Az európai kultúra három fő forrása a görög bölcselet, a római jog és a zsidó-keresztény vallásetika. A Biblia kétségkívül az európai kultúra egyik alappillére, melynek egyetemes erkölcsi elvei kimutathatóan beépültek a jogról és igazságosságról alkotott felfogásunkba. Elsőként a legalapvetőbb jogokat szeretném kimutatni a Tórában, majd a Tízparancsolatot vizsgálom abból a szempontból, miként hatnak annak máig érvényes alapelvei a törvényességrôl alkotott képünkre, végül kitérek az újszövetségi törvényértelmezésre és államfelfogásra. A Tóra Mózes törvényét és tágabb értelemben Mózes öt könyvét jelöli, amelyben a jogi korpusz helyet foglal, a történeti, elbeszélő részeken belül. Szűkebb értelemben a Tórán csak a törvényszövegeket értjük. A Tóra szó törvényt és tanítást jelent. Mózes öt könyve azonban nemcsak törvénykönyv, hanem történelemkönyv is. Mózes első könyve a világ teremtésétől kezdődő, az emberiség őstörténetét is felölelő narratívába ágyazza Izrael néppé válásának folyamatát, és leírja ennek központi eseményét, Isten és Izrael szövetségkötését, amelynek során a törvény kinyilatkoztatására került sor. A tórai alapértékek alatt egyfelől az ember teremtésétől fogva adott ősi, elidegeníthetetlen jogokat, másfelől a törvényadáskor kijelentett parancsolatok által védett értékeket értjük. A tórai alapértékeket a szövegforrások bemutatásával és magyarázatával kívánom feltárni. 


\section{A Biblia emberképe}

Az európai jogi gondolkozást nagymértékben meghatározza a Szentírás emberképe. „A Biblia szerint az. ember alapvetó jogai egyidösek az emberiséggel, mivel azok eleve hozzátapadnak az emberhez, tehát nem történelmileg keletkętek. Legalapvetöbb jogaink Istentöl származnak, azok ösi, elidegenithetetlen örökeségünket képezilk. (...) Ha szemügyre vesszük öket, rögtön szembeötlik, bogy a történelem folyamán sz̨inte mindegyiküuk állami törvényekkeel is megerösitést nyert." ${ }^{1}$ A Bibliából kitúnik, hogy az ember kivételes helyet foglal el az Isten által teremtett világmindenségben. Létezésének értelmes célja van. Az ember eredetét tekintve Isten elhatározásából és saját képmására teremtett lény, aki értelemmel, szabadsággal és kormányzati tekintéllyel van felruházva. ${ }^{2}$ Származásából és uralomra feljogosított mivoltából fakadóan tisztességre és megbecsülésre méltó. Az emberi méltóság legtömörebb megfogalmazása a 8. Zsoltárban olvasható, amely a bibliai humanizmus manifesztuma. „Micsoda az ember mondom hogy megemlékezel róla? És az embernek fia, hogy gondod van reá? Hiszen kevéssel tetted öt kisebbé az. Istennél, és dicsöséggel és tisz̨tességgel megkoronáżtad öt! Úrrá tetted öt kęzeid munkáin, mindent lábai alá vetettél.”3

Az ember eredendő, elidegeníthetetlen méltósága teremtésének módjából és céljából fakad. Az embert minden más élőlénytől megkülönbözteti teremtésének módja. Az Istennel való hasonlóság hordozója és letéteményese az emberbe belélehelt szellem (az „élet lehellete”), amit a Teremtő közvetlenül lehelt az ember orrába, és amitől az ember élő és gondolkodó lény lett. „És formálta vala az Úr Isten az embert a földnek porából, és lehellett vala az ô orrába életnek. lehelletét. Így lön az. ember élo lélekkeé."4 Az individuum értékére mutat az a tény, hogy Isten először egy egyént teremtett, és miután látta, hogy „nem jó az embernek egyedül’, társául megalkotta a nőt, mint „segitótársat, bozఇá illót." "5 Ennek fényében az ember jóléte érdekében cselekvő Teremtönek köszönhető az első emberi közösség, a házasság létrejötte. E kötelék kifejeződése, hogy az ember „ragaszkodik feleségéhez: és lesznek egy testte'. ${ }^{6}$

A házasság ezen egyszerű definíciója szerint az a nemek különbözőségén és a felek hűségén alapul. A házasság intézménye, mint férfi és nő egymás iránti elkötelezettsége „régebbi a társadalmaknál, államoknál, hiszen az elsô emberpárra vezethetō vissza." 7 Amennyiben a természet rendjéből jogi következtetést lehet levonni, a nemek különbözőségén alapuló házasság jogi védelme nem társadalmi konstrukción, hanem természeti törvény felismerésén nyugszik. Ahol a bibliai szöveg két nemről, a férfiról és a nőről tesz említést, ugyanott hangsúlyozza, hogy az ember Isten képmására lett teremtve, következésképpen mindkét nem tagjai egyenrangúak: egyformán8 rendelkeznek mind az istenképűség belső tartalmával, mind az abból fakadó méltósággal. „Teremté tehát az. Isten az embert az ő képére, Isten képére teremté öt: férfiúvá és asszonnyá teremté öket." "Teremtésének

\footnotetext{
${ }^{1}$ MÉSZÁros, Bibliai államelmélet 19.

2 CONNER, Foundations 123-130.

${ }^{3}$ Zsoltárok 8:5-7

41 Mózes 2:7

51 Mózes 2:18

61 Mózes 2:24b

${ }^{7}$ MÉSZÁROS, Bibliai államelmélet 20.

${ }^{8}$ Apostolok cselekedetei 17:26

91 Mózes 1:27
} 
céljait tekintve minden más élőlény közül kiemeli az embert, hogy a Föld benépesítésére, és a természet fölötti uralomra kapott felhatalmazást. „És megáldá Isten ökeet, és monda nékik Isten: Szaporodjatok és sokasodjatok, és töltsétek be a földet és hajtsátok birodalmatok alá; és uralkodjatok a tenger halain, az ég madarain, és a földön csús zó-mászó mindenféle állatokon. És monda Isten: Imé néktek adok minden magho ớ füvet az egész föld sæínén, és minden fát, amelyen maghozó gyümölcs van; az legyen néktetek eledelül."10 Az első emberpár a házasság és a család intézményének szentesítésével együtt tulajdonjogot kapott mind lakóhelyét illetően, mind pedig a természet adta javak birtokba vételét illetően. Az ember javára cselekvő Teremtő tulajdont és felelősséget bízott az emberre. „És vevé az Úr Isten az, embert, és belyezteté ôt az. Éden kertjébe, hogy mivelje és örizze azt." "A tulajdon intézménye az isteni jog szerint egyértelmüen magántulajdon: az egyénekhez, családokhoz, kötódik, az ö boldogulásukat szolgálja."12 Az édeni viszonyokból levezethető a családalapításhoz, a magántulajdonhoz, sőt az egészséges környezethez való jog is. ${ }^{13}$

\section{A törvény, a bün és az ítélet összefüggése}

A Biblia olyan emberképet tár elénk, ami szerint az emberi nemet az állatvilágtól megkülönbözteti, hogy Isten képmására teremtett, értelemmel és széleskörű cselekvési szabadsággal felruházott lény, aki szabad akarattal rendelkezik, épp ezért erkölcsi lény is. ${ }^{14}$ Szabadsága korlátait az a törvény határozta meg, aminek forrása maga Isten, ezért tetteiért neki tartozik felelősséggel. Az embernek adott első törvény egyetlen negatív parancsot tartalmazott, aminek megszegéséhez szankció kapcsolódott. Már az őstörténetben egyértelmű az összefüggés a törvény, a bűn és a bűnhődés között. A törvény áthágása a bűn, a bűn következménye a halál. A kert minden fájára és azok gyümölcseire vonatkozó széleskörű engedély mellett egyetlen tilalom figyelmeztetett a szabad cselekvés korlátjára. „De a jó és gonosz. tudásának fájáról, arról ne egyél; mert amely napon ejéndel arról, bizony meghalsæ:" 15

A törvény volt hivatott arra, hogy felszínre hozza az ember döntési felelősségének súlyát, az egyén morális mivoltát. A törvény megszegésével együtt járó a fenyegetés az élet elveszítésére egyúttal rávilágít a törvény céljára: megtartása az ember számára jó. A történetben az a mély gondolat sejlik fel, hogy az élet fája mindaddig hozzáférhetô, ameddig az emberiség a törvényt megtartja. A büntetési tétel az elvesztett élet értékét hozza felszínre. A jó törvények mindenkori kritériuma, hogy végső fokon az életet pártolja-e, az ember földi boldogulását célozza-e vagy sem, a büntetés arányos-e az okozott kár mértékével.

\footnotetext{
101 Mózes 1:28-29

111 Mózes 2:15

12 MÉSZÁros, Bibliai államelmélet 20.

13 MÉSZÁros, Bibliai államelmélet 20.

${ }^{14}$ CONNER, Foundations 124.

151 Mózes 2:17
} 


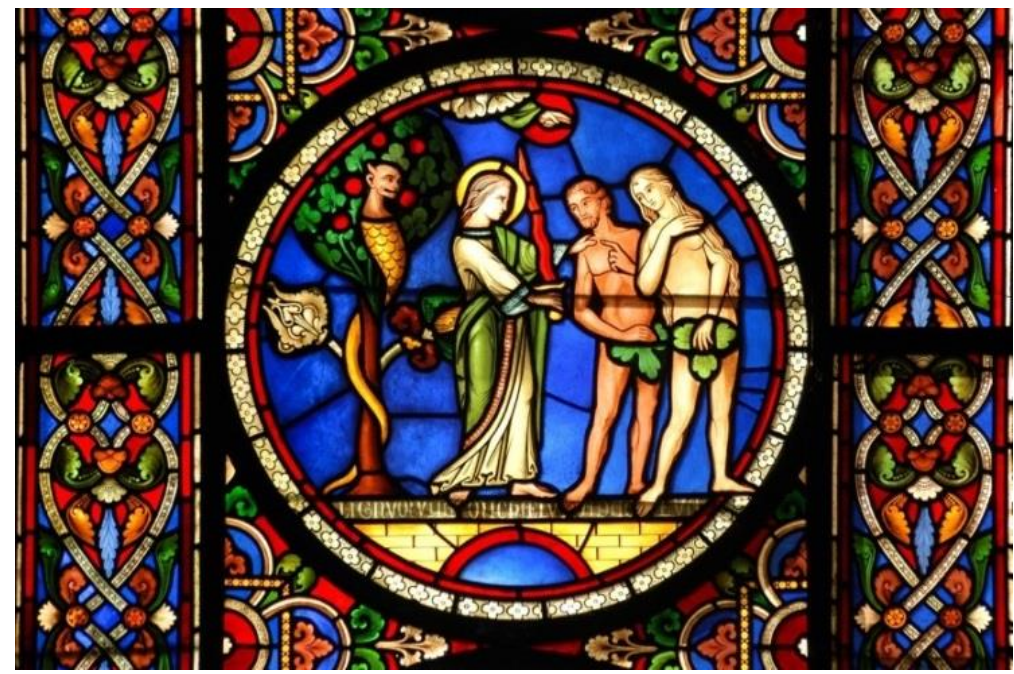

Ádám és leszármazottai a tilalom megszegését követően szükségképpen meg kellett ismerjék a bűn és a büntetés összefüggését, a szuverén Törvényhozó jogos büntető-igényét és azt, ahogy az gazságosság kívánalma szerint a törvénynek érvényt szerez.

1.kép: Angyal lángpallossal az igazságszolgáltatás jelképe

A paradicsomból való kiűzetés narratívája az emberi reakciókon keresztül ábrázolja, ahogyan a bűnös lelkiállapota megváltozik már azt megelőzően, hogy Isten kihirdette volna az ítéletet. A bűntudatot a bűn létére vezeti vissza, nem külső kondicionálásra, ami által tudatosult a törvénysértô magatartás. A lelkiismeret törvénye, mint szubjektív, a priori törvény akkor is vád alá helyezi az egyént, ha nincs jelen külső vádhatóság, és nincs előzetes ismerete, tapasztalata az ítéletről. A jó és rossz tudásának fája azért volt tilalmas, mert az ártatlanoknak a jó és rossz közötti határ ismeretlen: nem tudjuk, mi a rossz, amíg el nem követjük. A bủntudat a határsértést jelzi. A lelkiismeret törvényéből, mint univerzális emberi tapasztalatból természetjogi következtetést lehet levonni. A törvény és az igazságosság, a bűn és büntetés fogalma, a jogtudat eszerint egyidős az emberiséggel. A bűn és a büntetés definíciója az Újszövetségben lényegében változatlan maradt, „a bün pedig a törvénytelenség," "16 „a bün zsoldja halál’17 A vádlott meghallgatása szintén része az igazságos ítélethozatalnak. A Tórában a bűnbeesés történetében, Ádám kihallgatásánál találkozunk először vele. Káin esetében ugyancsak történt meghallgatás. A tisztességes eljárásra és az emberi élet védelmére a Tízparancsolat VI. és IX. cikkelye magyarázatánál térek ki bővebben.

\section{A Tóra alapértékei a Tízparancsolat tükrében}

\subsection{A Tóra, mint alapszerződés}

A törvényadás eseménye Izraelt a népek között sajátos egyedülálló jogi státusba helyezte. A szövetségkötés Mózes közvetítésével történt meg a Mindenható és választott népe, Izrael között, melyet Egyiptomból vezetett ki, hogy Kánaánban új hazát biztosítson neki az Ábrahámnak adott ígérete szerint. A mindkét félre kötelező érvénnyel bíró írásos szerződés létrejötte és a szerződést megelőző társadalmi közmegegyezés kialakítása minden bizonnyal mérföldkő a jog történelmében, messze túlmutat a kor szokásjogán vagy annak irodalmi formába öntésén ${ }^{18}$. Paul Johnson kiemeli a

\footnotetext{
161 János 3:4b

${ }^{17}$ Róma 6:23a

${ }^{18}$ H. Tadmor úgy véli, az ókori törvénykönyvek nem a mai értelemben vett törvénykönyvek, bár kódexnek hívják pl. Hammurapi kódexét, nem annyira a mindennapos döntéseket irányító eljárásjogi eszközök voltak, mint inkább a korabeli bírói gyakorlat sűrítménye, a helyi szokás szerinti döntések irodalmi formába öntése. Lásd BEN SASSON, History 118119.
} 
törvényadás társadalomformáló szerepét, mellyel az izraeliták újfajta társadalmat teremtettek: „, $A$ mózesi kódexben mindenféle kiváltság benne foglaltatik, de a lényeges kérdések tekintetében nem tesz. különbséget a bivök egyes csoportjai között. Valamennyiüknek része van a sqövetség elfogadásában; ez pedig népi, sốt demokratikus döntés volt. (...) Philo a rendszert < demokráciának > nevezte, amelyet úgy jellemzett, mint $<$ a legtörvénytisztelőbb és legjobb alkotmányt $>$."19

Tízparancsolat Izrael néppé válásának központi jogi dokumentuma, mely a szigorú erkölcsi monoteizmus talaján áll. Minden más mózesi törvény levezethető a dekalógusból, az esetjog nem más, mint ennek a tíz alapvető parancsolatnak a gyakorlati kifejtése és alkalmazása. Az esetjog kodifikációja a dekalógusban foglalt törvények elhangzását követi. Három törvénytípus különíthető el a Tórában: ezek részint erkölcsi parancsok (egyetemes etikai elvek); részint ceremoniális szabályok (speciálisan Izrael népére, földjére és istentiszteletére vonatkozó parancsok, melyek sajátos céllal elkülönítik más népektől, helyhez és néphez kötöttek); valamint polgári törvények (melyek a közjót szolgálják, elvei bárhol átültethetőek a gyakorlatba). A Tízparancsolat az első kategóriába tartozik. A két kőtáblának megfelelően ${ }^{20}$ két kategóriába sorolhatjuk a törvényeket: az elsô négy parancsolat Isten és ember viszonyát szabályozza, a további parancsolatok az ember és ember közötti viszonyt.

„És szólá Isten mindezeket az, igéket, mondván: Én, az Úr, vagyok a te Istened, aki kihoztalak téged Egyiptomnak. földéról, a szolgálat bázából.

I. Ne legyenek néked idegen isteneid én elöttem.

II. Ne csinálj magadnak faragott képet, és semmi hasonlót azokhoz, amelyek fenn az égben, vagy amelyek alant a földön, vagy amelyek a vižekben a föld alatt vannak. Ne imádd és ne tiszteld azokat; mert én, az Úr a te Istened, féltön-szeretố Isten vagyok, aki megbüntetem az atyák vétkét a fiakban, harmad és negyedĩiglen, akik engem gyülölnek. De irgalmasságot cselekszem ezzeríziglen azokekal, akik engem szeretnek, és az én parancsolatimat megtartják.

III. Az Úmak a te Istenednek nevét biába fel ne vedd; mert nem hagyja aẓt az Úr büntetés nélkeül, aki az ô nevét biába felveszi.

IV. Megemlékezzél a szombatnapról, hogy megszenteljed azt. Hat napon át munkálkodjál, és végezd minden dolgodat; De a hetedik nap az Úrnak a te Istenednek szombatja: semmi dolgot se tégy azon se magad, se fiad, se leányod, se szolgád, se szolgálóleányod, se barmod, se jövevényed, aki a te kapuidon belöl van; Mert hat napon teremté az Úr az eget és a földet, a tengert és mindent, ami azokban van, a hetedik napon pedig megnyugovék. Azért megáldá az Úr a szombat napját, és megszentelé azt.

$V$. Tisžteld atyádat és anyádat, hogy hosszú ideig élj azon a földön, amelyet az Úr a te Istened ád te néked.

VI. Ne ölj.

VII. Ne paráználkodjál.

VIII. Ne lopj.

IX. Ne tégy a te felebarátod ellen hamis tanúbironyságot.

X. Ne kivánd a te felebarátodnak házát. Ne kivánd a te felebarátodnak feleségét, se szolgáját, se szolgálóleányát, se ökrét, se szamarát, és semmit, ami a te felebarátodé."21

${ }^{19}$ JOHNSON, A zsidók története 58.

205 Mózes 10:3

212 Mózes 20:1-17; másik változata: 5 Mózes 5:6-21. 


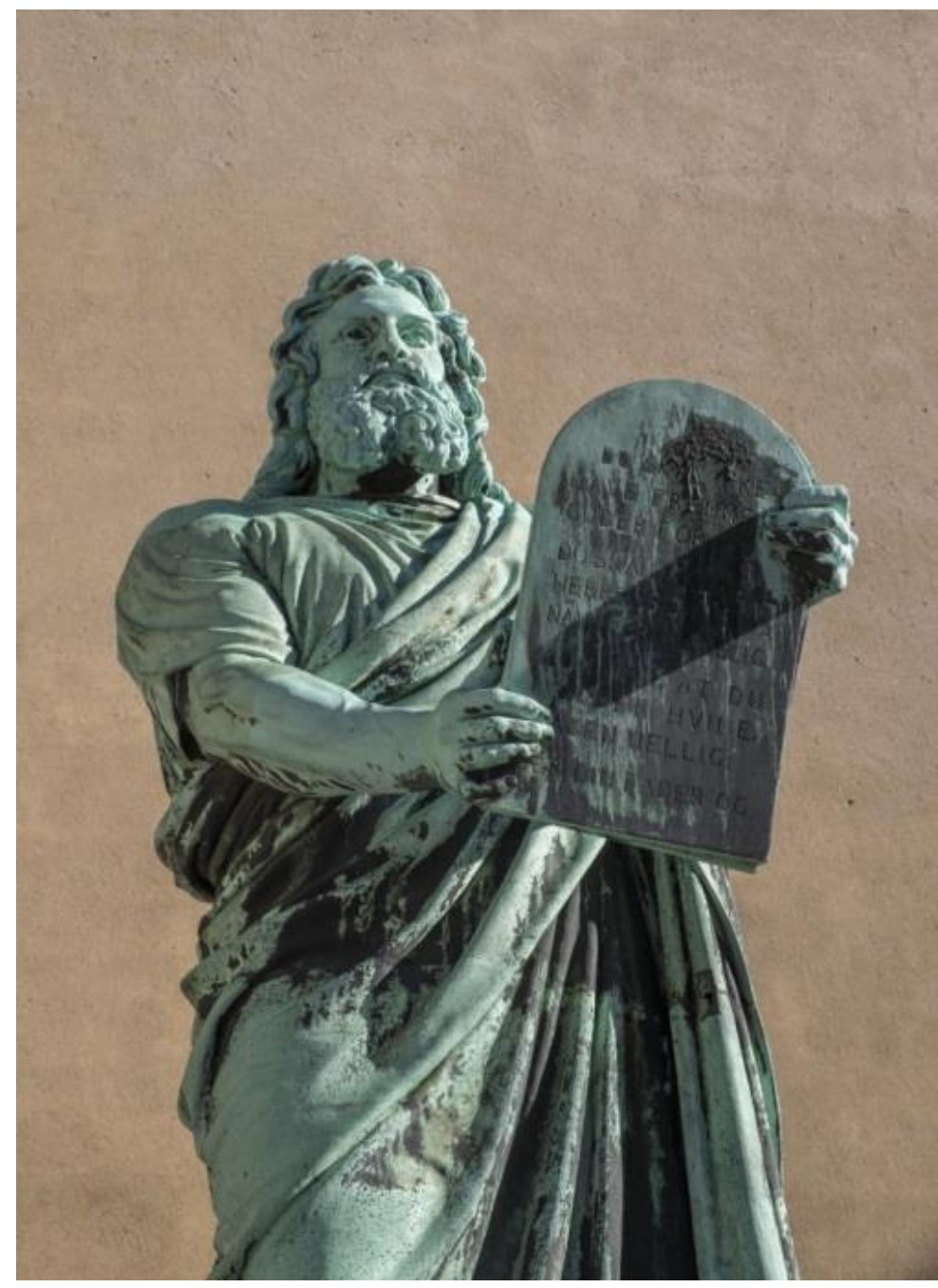

„A sqóban forgó erkölcsi szabályok némelyike más ókori közel-keleti civilizációkban is elterjedt; [...] Am ami az. Istennel és az emberrel szembeni helyes magatartás átfogó summáját illeti, amelyet egy egész népnek. felkinálnak, a nép pedig elfogadja és a szivébe vési, elmondható, bogy az. Tizparancsolatnak az egész. ókorban még csak halvány mása sem létezik." - írja Paul Johnson történész. Mint hangsúlyozza, a mózesi szövetség „az ösi közel-keleti szerzoódések, például a hettiták szerzódéseinek mintáját követi. Van egy történelmi bevezetése, amely kitüri a célt, ezt követi a vállalkozás természetének, az. isteni tanúknak, az áldásoknak és az. átkoknak megnevezése, majd a szöveg és végül a szöveget tartalmazó táblák lelöbelye. A mózesi szövetség azonban a maga nemében páratlan, mivel benne nem államok kötnek egyezséget, hanem Isten és a nép.".22

2. kép: Mózes a kőtáblákkal. Újfajta társadalmat teremtett

A Törvényadó ugyanakkor személyesen, egyes szám második személyben szólítja meg hallgatóját, ezzel szinte önmaga elé állítja az embert, mint egyént. Mivel a törvény isteni eredetû, mindenkire nézve kötelező, és ezért e törvény előtt - ahogyan Isten előtt - minden ember egyenlő.

A dekalógus a teljes törvényszöveg kiindulópontja és magva. Bevezetőből, történeti visszatekintésből és tíz valláserkölcsi parancsolatból áll, melyet részletes esetjogi magyarázat követ. Mózes ötödik könyvében a törvénykönyv záradéka áldásokat ígér a törvény megtartóinak, és átkokat helyez kilátásba a szövetségszegőknek, majd végül Isten tanúul hívja az eget és a földet. A dekalógus szövegét abból a szempontból fogom elemezni, hogy milyen jogi elvek következnek az egyes részekből, hogyan befolyásolják a törvények funkciójáról alkotott képünket.

\subsection{Preambulum}

„És szólá Isten mindezeket az, igéket, mondván: Én, az Úr, vagyok a te Istened, aki kihoztalak téged Egyiptomnak. földéról, a szolgálat házából."

22 JOHNSON, A zsidók története 51. 
Az ókori keleti alapszerződések mintájára a törvény történelmi bevezetéssel kezdődik. A közös vállalkozás szövegének preambuluma a szövetséget kezdeményező fél bemutatkozását tartalmazza: először nevét, majd történelmi tettét említi, ami az Exodus volt. A szerződés az egész népre vonatkozik, azaz kollektív, a megszólítás viszont egyes szám második személyú, azaz személy szerint a nép minden tagjának szól. A bevezető szakaszban megfogalmazott gondolat, hogy az emberi szabadság védendő érték. A szabadság az elnyomás ellentéte.

A zsarnokság Egyiptomban Jákob leszármazottai elleni etnikai tisztogatással felérő demográfiai háborúval, kezdődött, kényszermunkával folytatódott és a héberek istentiszteletének állami meggátlásával csúcsosodott ki. A transzcendens boldogság keresése alapvető jog. A szabadság, egyének és népek vonatkozásában egyaránt Isten ajándéka, hogy ezt a jogát minden ember gyakorolhassa.

\subsection{Az egyetlen Isten tisztelete}

„I. Ne legyenek néked idegen isteneid én elöttem. II. Ne csinálj magadnak faragott képet, és semmi hasonlót azokhoz, amelyek, fenn az égben, vagy amelyek alant a földön, vagy amelyek a vizekben a föld alatt vannak. Ne imádd és ne tiszteld azokat; mert én, az Úr a te Istened, féltön-szeretö Isten vagyok, aki megbüntetem az atyák vétkét a fiakban, harmad és negyedíriglen, akik. engem gyülölnek. De irgalmasságot cselekszem ezeríiglen azok.kal, akike engem szeretnek, és az én parancsolatimat megtartják."

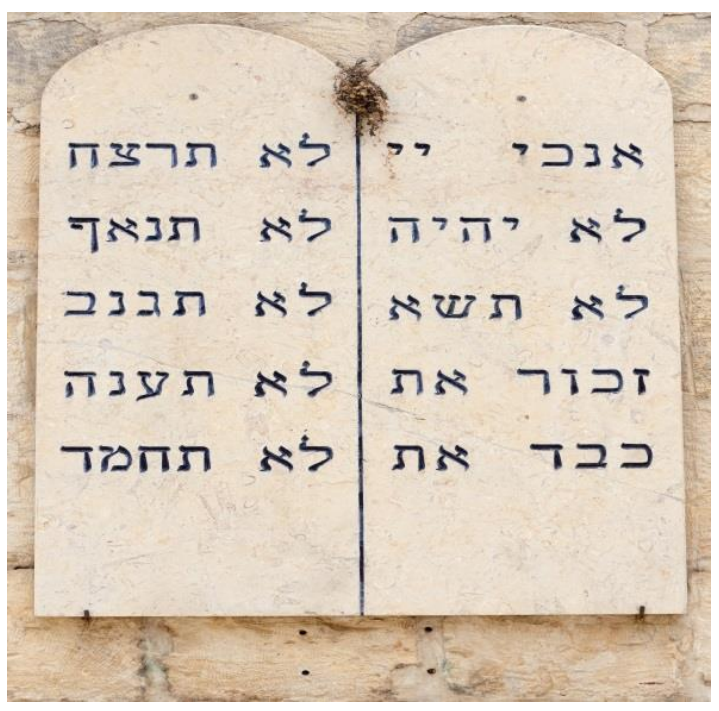

Az első két parancsolatban megfogalmazódik, hogy Isten szuverén törvényadó és legfőbb bíró, aki él a büntetés és megjutalmazás eszközével. A Törvény záradékában megerōsíti, hogy „Enyém a bosszuállás és megfizetés.” 23 A Tóra a szigorú erkölcsi monoteizmus talaján áll és mindenféle istenábrázolást tilt. A benne foglalt törvényeket Isten kinyilatkoztatott akaratának tekinti, amit Izraellel megismertetett történelmi térben és időben, akinek ezáltal morális kötelezettsége keletkezett ennek védelmére és megőrzésére a korokon át, a jellemzően politeista környezetben.

3. kép: Ezek az utcát díszítő kőtáblák a Tízparancsolatra emlékeztetnek Jeruzsálemben

Az idegen istenségek figuratív ábrázolásainak megsemmisítése része volt Izrael küldetésének, és elsősorban önvédelemként szolgált, nehogy a szinkretizmussal kultúraváltás történjen, a kultúraváltással pedig a vallás megváltoztatása. ${ }^{24}$ Az idegen kultuszok bevezetésével

\footnotetext{
235 Mózes 32:35a

242 Mózes 34:12-17
} 
szembeni ellenállásra vonatkozó alábbi törvény érdekes módon nyomozóhatóság felállítását szorgalmazza az új hazában: „Ha valamelyikben a te városaid közül, amelyeket az Úr, a te Istened ád néked, hogy ott lakjál, eat hallod mondani: Emberek jöttek ki közülled, istentelenségnek fiai, és elforditják városuk. lakosait, mondván: Nosza, menjünk és tiszteljünk idegen isteneket, akiket nem ismertetek: Akkor keress, kutass és szorgalmatosan tudakozódjál, és ha igaz, és bizonyos a dolog, és megtörtént az efféle útálatosság közötted: Hányd kard élére annak a városnak lakosait; áldozd fel azt mindenestól, ami benne van; a barmát is kard élére hányd."25 Az információszerzésre, majd ezt követően az értesülések ellenőrzésére a lakosság védelmében van szükség, hogy ne tudják a mózesi vallási reform visszafordításával destabilizálni az országot, mert ennek a környező népekhez történő asszimiláció lenne a következménye. A passzus az állambiztonsági törvények előfutára.

\subsection{A megszentelendő Név}

„III. Az Úrnak a te Istenednek nevét biába fel ne vedd; mert nem bagyja ą̧ az Úr büntetés nélkül, aki az ő nevét biába felveszi."

\subsubsection{A közbeszéd tisztasága}

Szentségtörés és hamis eskü elleni törvény, mely a közbeszéd tisztaságát volt hivatott biztosítani, hiszen kimondja, hogy a szent Név nem tehető profánná. A káromkodás, átkozódás büntetésére volt precedens a pusztai vándorlás korszakában. ${ }^{26}$ Miután az ünnepélyes eskütétel egyfajta invokáció is volt, a törvény elrettentett a könnyelmű esküdözéstől, ezáltal az adott szó jelentőségére hívta föl a figyelmet. Az Újszövetségben Jézus az égre-földre esküdözést szükségképpen elbizakodott hazugságnak minősíti, ezért az egyenes beszédre szólít fel. ${ }^{27}$

A Tóra egyúttal a vallási állitások megvizsgálására nemcsak szabadságot adott, hanem egyenesen megkövetelte azt. Az Úr nevében bizonyíthatóan hazugságot állító egyének, az ún. hamis próféták rendszerint feleltek tettükért ${ }^{28}$, ami mai fogalmaink szerint a közgondolkodást irányítókkal szemben felállított magas mércére irányítja a figyelmet. Az objektív kritériumok felállitása továbbá a vallásokkal és vallási nézetekkel szembeni egészséges kritikai érzéket engedte kifejlődni. A vallások és vallási állítások bírálhatók, összemérhetők, ez a nézet szilárdan gyökeret vert a zsidókeresztény forrásokból táplálkozó gondolkodásban. Mindemellett a szabadság mellett a III. parancsolat magas erkölcsi színvonalat feltételez, olyan társadalmat, aminek a középpontjában Isten tisztelete áll, akinek személyazonosságát nem hamisítják meg, nevével nem élnek vissza. A szólásszabadság korlátait a blaszfémia tilalma jelenti.

\footnotetext{
255 Mózes 13:12-15

263 Mózes 24:14

${ }^{27}$ Máté 5:33-37

285 Mózes 18:20-22; Jeremiás 28.
} 


\subsubsection{A törvény uralma és a hatalmi ágak elválasztása}

Az eszményi Izrael papok birodalma, szent nép ${ }^{29}$, akiknek igazságos törvényeik vannak, jogrendje minta a többi nép számára. A jó jogrend kiemelkedően jogkövetővé tud tenni egy társadalmat. „Megtartsátok azért és megcselekedjétek! Mert ez. lesz a ti bölcsességtek és értelmetek a népek elött, akik meghallják majd mind e rendeléseket, és ezt mondják: Bizony bölcs és értelmes nép ę a nagy nemzet!"30 A teokratikus alkotmányon nyugvó társadalmi berendezkedés kivételes jelenség az ókori kelet viszonyai között, még akkor is, ha a teljes igazságosság elérendő ideál maradt. Minden emberre vonatkozóan a törvény uralma érvényesült és nem a kevesek, nem despoták vagy istenkirályok uralma. Három jelentős hivatal nyugodott a tórai jogon: aki a törvényt kihirdette: próféta volt, a törvény pedig szabályozta a papság és a civil hatóság (a királyság) intézményes kereteit, múködésük illetékességi körét.

Az Ószövetségben a királyi és papi funkció mereven elkülönült egymástól. Ez azt jelenti, hogy az állami és vallási hivatal nem fonódhatott össze. A szólásszabadságot képviselő próféta pedig mindkettőt bírálhatta. A zsarnokság kialakulását meggátoló ellenőrző funkciók annyiban levezethetôk belőle, amennyiben a királyi, prófétai, papi tisztségek egymást ellenőrző feladatkört láttak el, megteremtve ezzel a fékek és ellensúlyok rendszerét a társadalomban. A papok döntései vallási kérdésekben domináltak, de volt civil bíróság, a papok többnyire tanították, magyarázták a Törvényt. ${ }^{31}$ A legfelsőbb bíró a király volt. Ugyancsak a próféták emlékeztettek az Istentól kapott törvény szellemére, ha attól a nép elszakadt, vagy a hatalom elcsűrte-csavarta, és csak betújében tartotta meg. Az Újszövetségben Jézus, mint próféta hívta fel figyelmet a törvény életközpontú tartalmára, szemben annak puszta törvénykénti, formális megtartásával és emberi rendeletekkel való hatálytalanításával. ${ }^{32}$ A királyi és papi funkció elválasztása olyan modell, aminek messze ható következménye van a lelkiismereti- és vallásszabadság tekintetében. A papság és a királyság ószövetségi elkülönítése az állam és egyház szétválasztásának mintája lett a nyugati jogi gondolkodásban. Az egyház és állam szétválasztásának elve szerint a hatalom a hit dolgába nem avatkozhat bele, vallási ügyekben tartalmilag nem illetékes.

A jogi pozitivizmus felfogásával ellentétben a jognak abszolút (magától értetődő) erkölcsi törvényeken kell nyugodnia. A Tóra a társadalom minden szférájában megteremti az erkölcsi minimum alapját. Szükségképpen felmerül tehát a jogharmonizáció igénye is. „Óh, község! Nékteke és a köztetek lakozó jövevénynek egy rendtartástok legyen; örökkévvaló törvény legyen a ti nemzetségeiteknél, hogy az. Úr elött olyan legyen a jövevény, mint ti. Egy törvényetek legyen, és egy szabályotok néktek és a jövevénynek, amely közöttetek lakik." 33 A törvény uralma, a jogállam az a kívánatos társadalmi berendezkedés, amit a nyugati civilizáció magáénak vall. A törvény uralma jogbiztonságot jelent a hatóköre alá tartozó minden egyes polgár számára.

\footnotetext{
292 Mózes 19:6

305 Mózes 4:6

315 Mózes 17:9

32 Számos alkalommal, pl. Máté 15:1-9

334 Mózes 15:15-16
} 


\subsection{Munkaszünet és társadalmi igazságosság}

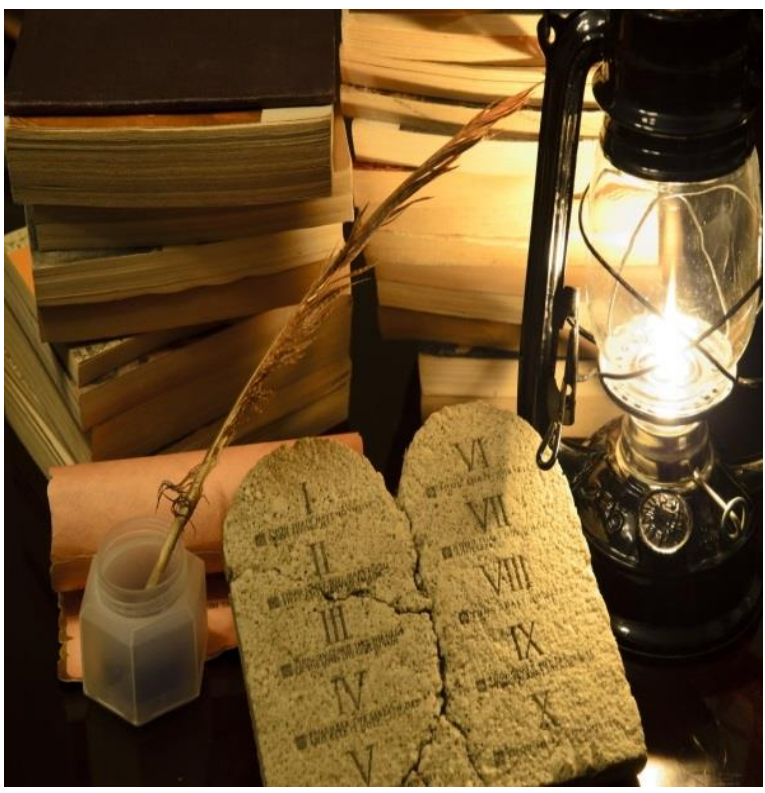

„IV. Megemlékezzél a szombatnapról, hogy megszenteljed azt. Hat napon át munkálkodjál, és végezd minden dolgodat; De a betedik nap az Úrnak a te Istenednek szombatja: semmi dolgot se tégy azon se magad, se fiad, se leányod, se szolgád, se szolgálóleányod, se barmod, se jövevényed, aki a te kapuidon belöl van; Mert hat napon teremté az. Úr az, eget és a földet, a tengert és mindent, ami azokban van, a hetedik napon pedig megnyugovék. Azért megáldá az Úr a szombat napját, és megszentelé åt.".

A szombattörvény az ember természetfölötti dimenzióját és értékét állítja elénk. Nem pusztán munkaerô, és sem az állam, sem a munka nem boldogítja. A személyes Isten az embert személynek tekinti, akivel személyközi kapcsolatban áll, és aki soha nem válhat eszközzé, nem tárgyiasodhat el. A gazdasági racionalitáson és társadalmi hasznosságon felül értékes. „Mert az én szolgáim Izráel fiai, az én szolgáim ök, akiket kihoztam Egyiptom földéröl. Én vagyok az. Úr, a ti Istenetek."”34

\subsubsection{A pihenőnap társadalmi hatása}

A pihenőnap elrendeléséből a társadalmi igazságosság eszménye vezethető le. Az Exodus társadalmi vívmánya az volt, hogy a rabszolgasorból egy nép kiemelkedett, és szabad lett; megkapta az önrendelkezés jogát. Heti egy napon pedig a megnyert szabadságával teljes mértékben élhet. A pihenőnap indoklása más megfogalmazásban ${ }^{35}$ az, hogy engedjék uraik a szolgáikat is pihenni, és emlékezzenek vissza, hogy rabszolgák voltak Egyiptomban. Mindenkinek jár egy pihenőnap, hogy regenerálódjon, függetlenül a társadalomban elfoglalt pozíciójától, nemétől, korától, vagy származásától. A parancs megfogalmazása a törvény előtti egyenlőséget erősíti meg. A pihenőnap össztársadalmi hatását tekintve rendkívül pozitív intézkedés, hiszen mindenki számára törvény által biztosítja a szabadidőt, hogy visszanyerje fizikai, mentális és lelki egészségét. A pihenés mai fogalmaink szerint a kiégés elkerülését és a kreatív energiák megújulását eredményezi.

A Törvényben a szombattörvények egész skálájáról olvasunk. A szombattörvény vallási jelentőségén túlmenően szociális intézkedéscsomagot foglalt magában. ${ }^{36}$ Hétéves ciklusokban elrendelték a rabszolgák felszabadítását Hétszer hét év számlálása után következő minden

\footnotetext{
343 Mózes 25:55

355 Mózes 5:15

363 Mózes 25:1-55
} 
ötvenedik esztendőben felszabadultak az adósok, az eladósodottak visszakaphatták elzálogosított birtokukat. A szombatév a vagyoni különbségeken jelentősen enyhített, az ötvenedik esztendő, a jubileumi év pedig lehetôvé tette a tartósan eladósodottak számára az újrakezdés esélyét, a lecsúszott társadalmi rétegeknek a konszolidált életmódba való visszakapaszkodást.

A Tóra a termőföld parlagon hagyását is elrendelte, hogy pihentetésével megújuljon a föld termőereje. A vetésforgó európai bevezetése szintén a föld pihentetésén alapul, ami által nagyobb termést értek el. A nagyobb termésátlag több élelmiszert, jobban táplált lakosságot és jobb életminőséget, akár nagyobb születésszámot jelent.

Az önrendelkezéshez szükséges az egészség, amivel az egyén képes az öngondoskodásra. Az egészség és a munkaképesség értékére tekintettel, egy közösség tagjai egymás egészségéért kölcsönösen felelősek. „És ha férfiak összevesznek, és megüti valaki az ö felebarátját kốvel vagy öklével, és nem hal meg, hanem ágyba esik: Ha felkél, és mankóján kinn jár: ne legyen büntetve aそ, aki megütötte; csupán fekvéséert fizessen és gyógyittassa meg." ${ }_{37} \mathrm{Ha}$ valaki embertársa testi épségét, munkaképességét megkárosította, a törvény kötelezte, hogy fizesse ki annak egészségügyi ellátását, és a munkából kieső napokat táppénz gyanánt. A fenti törvényben a betegbiztosítás gyökereit láthatjuk.

\subsection{A család védelme}

„V. Tiszteld atyádat és anyádat, hogy hosszú ideig élj azon a földön, amelyet az Úr a te Istened ád te néked."

A törvényeket pozitív és negatív előjellel ellátva beszélhetünk pozitív parancsokról, (tedd ezt és ezt) és negatív parancsról, azaz tiltásról. A törvények megfogalmazása néhol tartalmaz indoklást, néhol egyetlen kategorikus tilalomból áll. Az ötödik parancsolat egy felszólítás, amihez ígéret is fűződik, méghozzá a hosszú és jó élet ígérete, olyan földön, melyet Isten jelölt ki az embernek. A család funkciójának felértékelése, a szülők tisztelete és a szülőföld szeretete természetes módon összekapcsolódik.

Az első földi intézmény eredetét és jelentőségét tekintve is a házasság és a család. Az egyén számára szintén az első emberi közösség, amelynek részévé válik. Mivel a házasság kölcsönös szereteten alapul, a családban alakul ki a gyermek önértékelése és életigenlő mentalitása. A szülők kötelessége szeretettel gondozni a gyermeket, a szülőket pedig megilleti a tisztelet az életadásért és gondoskodásért. A társadalom szövete az egészséges családok sejtjeiből fejlődik ki és épül tovább. A tisztelet parancsa teszi lehetôvé az egyén számára minden más, alá-fölérendeltségen alapuló viszonyba való beilleszkedést. Más szóval bármely tekintélyi rendbe való betagozódás, együttmúködési készség kialakulása a szülők tiszteletével kezdődik.

A tisztelet kultúrájának meghonosítása a nevelés által történik és elengedhetetlen ahhoz, hogy nagyobb emberi közösség jöhessen létre. Aki a kisebb, az a családi közösségben együttműködést tanul és képes a nagyobb közösségben is értékteremtő és értékhordozó ember lenni. A család nemcsak szociális készségeket segít elsajátítani, hanem ismereteket is. A szülő az első nevelő, akinek ebbéli kompetenciáját ez a parancsolat megerősíti, miután a következő nemzedékekért vállán nyugvó felelősségére az első két parancsolat már felhívta a figyelmet. Az

\footnotetext{
372 Mózes 21:18-19
} 
oktatás, nevelés kiemelkedő fontosságára világít rá, ami nélkül semmilyen interperszonális kapcsolatra vonatkozó parancsnak nem lenne foganatja. A következő nemzedék nevelése, tanítása elsősorban szülői feladat, de az ismeretek széles skáláját lehetőleg minden gyermeknek egységesen átadni a közoktatás által lehetséges. ${ }^{38}$ A szülők mint életadók és nevelők tekintélyükben azért nyernek védelmet és megerősítést, mert a Törvényadó életpárti, jövőorientált társadalmat vizionál, ahol az egyén tehetsége fejleszthető.

Az V. parancsolatban a szociális háló szükségessége, a társadalmi gondoskodás alapgondolata is benne van. A szülő tisztelete az idős szülő eltartását, ellátását is magában foglalja, ezáltal a nyugdíjrendszer ősének tekinthető. A családon túlnövő gondoskodás a szegények megsegítése, a jótékonykodás. A kiszolgáltatott emberek közösségi segitése, életlehetőséghez és ellátáshoz juttatása kifejezett parancs. Az árvák, jövevények, özvegyek felkarolása olyan tevékenység, melyeket a Tóra kifejezett parancsba adott. ${ }^{39}$ Kifosztásuk, ellehetetlenítésük égbekiáltó bűn, amitôl nemcsak a Törvény, hanem a próféták és a tanító jellegû írások óva intenek.40 Kiszolgáltatott lehet a munkaadójának az alkalmazott is, akinek visszatartják a bérét.

Az utolsó júdabeli írópróféta, Malakiás tolmácsolásában a Seregek Ura perel azért, hogy a társadalom állapota javuljon. „Mert itéletre indulok hozzátok, és gyors tanú leszek a szemfényvesztók ellen, a paráznák és hamisan esküvök ellen, és azok ellen, akik megröviditite a munkásnak bérét, az özvegyet és árvát, és akik nyomorgatják az idegent, és nem félnek engem, ąt mondja a Seregeknek Ura." ${ }^{41}$ Az idősek tisztelete szintén tórai parancsolat, amely fontos érték a tekintélytiszteleten alapuló társadalmakban. Legköznapibb alkalmazása törvény szövegének a felirat, amely a modern Izraelben a tömegközlekedési eszközökön szólítja fel az utasokat, hogy adják át helyüket az időseknek. Így szól: „Az ő̌sz ember elött kelj fel". ${ }^{42}$

\subsection{Az emberi élet védelme}

$$
\text { „VI. Ne ölj.” }
$$

A Teremtés könyvéből egyértelmú, hogy az emberi élet a jog által védendő legfontosabb érték. Az ölést kifejező héber szó gyöke (rácah) kifejezetten az emberölésre, a gyilkosságra vonatkozik. Az emberi élet egyszeri, megismételhetetlen, mivel visszaadni emberileg lehetetlen, ezért életet elvenni sem szabad. Emberi életet kioltani bűn. Az emberölés szankcionálása jóval régebbi, mint a mózesi törvény.

Az Édenből való kiűzetést követően azonnal megtörtént az emberi élet kioltása miatti felelősségre-vonás Káinnal szemben, amiért megölte testvérét, Ábelt.43 „Monda pedig az Úr: Mit

\footnotetext{
${ }^{38}$ Az első ismert, egységes, közpénzből fenntartott iskolarendszert a Hasmoneus uralkodóház vezette Júdeában állíttatta fel Simon ben Setach, farizeus tudós, a Szanhedrin feje, i.e. 75-ben.

395 Mózes 14:29; 16:11-14

402 Mózes 22: 22; Jeremiás 22:3; Ezékiel 22:7; Zakariás 7:10; Példabeszédek 23:10-11

${ }^{41}$ Malakiás 3:5

423 Mózes 19:32a

431 Mózes 4:8-15
} 
cselekedtél? A te atyádfiának vére kiált én hozzám a földröl." ${ }_{44}$ Emberi bíróság még nem ítélte el és nem büntethette meg a gyilkost, kizárólag Isten szava sújtott le a lelkiismeretére.

\subsubsection{Az államhatalom legitimációja}

Az emberi élet védelmében a vízözön után, Noéval kötött szövetség keretében Isten feljogosította az embereket a gyilkosság megtorlására, ezáltal a bíróság és a büntetőhatalom felállítására adott parancsot: „Aki ember-vért ont, annak vére ember által ontassék ki; mert Isten a maga képére teremté az. embert."45 A mondat ritmikus és szimmetrikus verssor, amely tartalmazza magára az igazságszolgáltatásra vonatkozó törvényt, az emberölés esetében kiszabandó büntetési tételt az elkövetőre, és annak bírói indoklását. Az igazságszolgáltatás alapelve a lex talionis, a tett súlyával arányos büntetés elve. Ez az utasítás az emberi közösségekben egyetemlegesen a bíróság felállítására, és a büntetőhatalom létrehozására adott felhatalmazást, ami az államok kialakulásához vezetett. „Isten a gyilkosságot már Noé idejében büntetni rendelte (1 Mózes 9:6), a ’Ne ölj? parancsa később erre erősített rá." 40

A dekalógust követő és magyarázó polgári törvények továbbá részletezik a testi sértés, a súlyos testi sértés esetében kiszabandó büntetéseket és a véletlen baleset okozásakor bekövetkező haláleseteket, amikor a közkegyelem intézménye léphet múködésbe. Ennek a formája a mózesi törvényben a menedékvárosok rendelése, ahol a vérbosszú elől védelmet kapott a nem szándékos emberölést elkövető ember. A gyilkosok halálbüntetéssel sújtása adja az állam és büntetőhatalmának legitimációját. Figyelemreméltó, hogy a Törvény meghagyta a szokásjogot, melynek alapján saját hatáskörben is eljárhattak az ókori Izraelben: rokon is bosszút állhatott megölt rokonáért a gyilkoson ott, ahová az állam keze nem ért el. Ebből is látszik, hogy a gyilkosok halálbüntetése nemcsak elrettentésül szolgált, hanem igazságot is szolgáltatott az áldozat családjának. Ugyanakkor az áldozat családtagja fellebbezhetett ez ellen. Egy realisztikus jogesetről olvasunk Dávid király krónikájában, melyben egy anya a királytól kér védelmet a rokonsággal szemben, hogy ne veszítse el megmaradt fiát, aki másik fiát megölte. ${ }^{47} \mathrm{Az}$ önbíráskodás helyett a modern polgári társadalomban a polgár az államra ruházta a fegyver viselésének jogát. A fegyverviselés ma is kérdéseket vet fel: van ahol szinte teljesen, van ahol kevésbé állami monopólium. A polgárok és az állam szerződésén múlik, mit tekintenek az élet leghatékonyabb védelmének.

\subsubsection{Az élet védelme fogantatástól a természetes halálig}

Hasonlóan nagy vita tárgya az önrendelkezés joga és mások élethez való jogának ütköztetése. Az emberi élet bibliai szemléletét védelmezők szerint az élet a fogantatástól a természetes halálig tart. Ennek a koncepciónak megfelelően az abortusz, az eutanázia (és az öngyilkosság) egyaránt emberi élet szándékos, önkényes kioltása, per definitionem emberölés. A magzat, noha önálló életre még

\footnotetext{
441 Mózes 4:10

451 Mózes 9:6

${ }^{46}$ MÉSZÁros, Bibliai államelmélet 19.

472 Sámuel 14:1-11
} 
képtelen, nem tekinthető az anya testrészének, mert teste kezdettől egyedi és sajátos; már az anyaméhben személyiségjegyekkel rendelkezik ${ }^{48}$, ennél fogva jogalany, élete méltó a védelemre. „Bizony te alkottad veséimet, te takargattál engem anyám mébében. (...) Látták szemeid az én alaktalan testemet, és könyvedben ezek mind be voltak irva: a napok is, amelyeken formáltatni fognak; bolott egy sem volt még meg köəülï̈k.”" Az emberi testet nagyra becsüli a Szentírás. „Nemcsak az emberélet szent, hanem az Isten képére formált emberi lény is nagy becsben áll." ${ }^{50}$

\subsection{A házasság védelme}

\section{„VII. Ne paráználkodjál.”}

A VII. parancsolat a szexuáletika témakörét öleli fel. A héber kifejezés (näaf) a házassági hủtlenség tényállására utal, a házasság nélküli viszonyok közül külön szó csak a prostitúcióra van, ezért átfogó értelemben mindennemú nemi erkölcsbe ütköző cselekményt érthetünk alatta. Az európai jogfelfogás a keresztény, evangéliumi törvényértelmezést a tekintette hosszú ideig iránymutatónak, ami a monogám házasságot, az egy férfi és egy nő szövetségén alapuló házasság intézményét törvényi védelemben részesíti. A magyar Alaptörvény mindeddig a hagyományos házasságot ruházza fel különleges státusszal. Az élethosszig tartó, kölcsönös hűségen és szereteten alapuló házasság biztosítja férfi és nő számára az utódnemzéshez szükséges érzelmi, fizikai és anyagi biztonságot, ami egyben a gyermekek legjobb környezetét jelenti és a felnevelésükkel járó terhet megkönnyíti. A szülői tisztelet kapcsán már szó esett a család szükségességéről és társadalmi hasznáról. A hűségen alapuló monogám házasság a lelki és testi egészség számára is kedvező. Minimálisra szorítja a szexuális úton terjedő betegségek kockázatát, melyeknek önmagában is képes (lenne) gátat vetni. ${ }^{51}$ A népesség növekedését leginkább a monogám házasság tudja biztosítani egy nemzetben. A házasság polgári szerződés, amiből jogok és kötelezettségek származnak. A válást a tórai jog enyhébben, az Újszövetség szigorúan ítéli meg, de közös abban, hogy formális keretei vannak, törvényes indoklás nélkül nem szűnik meg. ${ }^{52}$

A Tóra tiltja a házasságon kívüli, a közeli rokonok közötti és az egynemúek közötti nemi kapcsolatot, továbbá az állatokkal való nemi közösülést. ${ }^{53}$ A gyermekáldozat tiltása ugyanabban a törvénycsomagban kapott helyet, mint a vérfertőzés és perverzió tilalma. A „Ne paráználkodj” parancsolat hatálya alá tartoznak a különféle, a nemi erkölcsbe ütköző cselekmények, például a nemi erőszak eseteinek szankcionálása ${ }^{54}$, amit a modern polgári állami törvény továbbra is szankcionál. A prostitúciót úgy tiltja, hogy a fiatalra döntő befolyással bíró személyt, jelesül a patriarkális családban az apákat szólítja fel, hogy ne becstelenítsék meg a lányukat azzal, hogy prostituáltnak adják. Ilyen módon a törvény a prostituáltat magát inkább áldozatnak tekinti, a prostitúció

\footnotetext{
${ }^{48}$ Zsoltárok 139:13-16; Jeremiás 1:5; Lukács evangéliuma 1:43-44

49 Zsoltárok 139:13,16

${ }^{50}$ JOHNSON, A zsidók története 50.

51 MCMillEN, Elkerülhető betegségek 42-51.

52 Máté 19:1-9, ahol Jézus utal a könnyítést jelentő válólevélre.

533 Mózes 18

545 Mózes 22:23-27
} 
irányában befolyásoló környezetet pedig felelősnek. Az okot és nem pusztán a negatív társadalmi jelenséget, mint okozatot kívánja megszüntetni. ${ }^{55}$

\subsection{A magántulajdon védelme}

„VIII. Ne lopj.”

A VIII. parancsolat a magántulajdonhoz való jog védelmét biztosító törvény. A magántulajdonban egy személy életideje, tehetsége, munkája testesül meg, ezért védelem alatt áll. Más tulajdonának elvétele törvénybe ütközik, amit a Tóra szankcionál. Mózes törvénye egyedülálló újdonsága volt az i.e. 2. évezred ókori keleti jogi környezetében, hogy az ember értékét messze az anyagi értékek fölé emeli. Míg Hammurapi törvényei a lopás miatt (egy kivétellel) minden esetben halálbüntetést róttak ki56, Mózes törvénye egyetlen esetben, az éjszakai betörővel szembeni jogos önvédelem esetében ismeri el annak jogosságát, fényes nappal a tolvaj életének a kioltása ugyanúgy gyilkosságnak minôsül, mint más emberölés. Míg a mezopotámiai kódex csak a közönséges lopás egy enyhe esetében engedte a tolvajnak, hogy kárpótlás megfizetésével mentesüljön a büntetés alól, de ha fizetésképtelen volt, akkor ő is életével fizetett; addig Mózes törvénye rendszerint a kár megtérítését írta elő, a rablás, lopás, sikkasztás, hűtlen kezelés eseteiben, az elkövetőt különböző mértékủ pénzbeli kárpótlás megfizetésére kötelezve.

Az emberrablás esetében viszont éppen fordítva van: a tórai rendelkezés szerint „aki embert lop, és eladja, halállal lakoljon." ${ }_{57}$ Ez a szabály viszont ismét azt az értékrendet erősíti meg, hogy az ember nem lehet árucikk. A túszejtőkkel szembeni rendőri, katonai fellépés etikai vetületét megvilágíthatja, hogy aki embert lop, nem egyszerú tolvaj, hanem egy emberi életet tesz tönkre, megfosztva eredeti rendeltetésétől. A tórai szabályozás tehát az ember anyagi javakkal összemérhetetlen értékére mutat rá. Az emberrablás kategóriájába nemcsak a túszejtést sorolhatjuk, hanem a rabszolga-kereskedelmet, az emberi test áruba bocsátása céljából zajló emberkereskedelmet, valószínúleg számos esetben a kerítéssel, futtatással, prostitúcióval anyagi haszonra szert tévő szervezett bűnözők tevékenységét is. Az emberkereskedelmet tiltó törvény mindezeknek a káros társadalmi jelenségeknek hathatósan elejét vette. Bővebb megfogalmazása így szól: „Hogyha rajtakapnak valakit, aki embert lop az ő atyjafiai közül, Izráel fiai közül, és hatalmaskodik. rajta, vagy eladja ąt: haljon meg az a tolvaj. Így tisztitsd ki a gonosz̨t te közülled." 58 Különféle károkozások is a „ne lopj” kategóriájába sorolhatók. A magántulajdon védelmére vonatkozó további törvények tiltják az olyan anyagi természetû visszaéléseket, mint a hűtlen kezelés, sikkasztás, orgazdaság, zsarolás (magántulajdon erőszakkal, fenyegetéssel való megszerzése) és a csalás, amire a kettős mérce tilalma vonatkozik. „Ne kövessetek el igazságtalanságot az itéletben, a hosszmértékben, súlymértékben és ûrmértékben." ${ }^{99}$ Még plasztikusabban fejezi ki ugyanezt egy másik törvény, ami a pénz és a szemes

\footnotetext{
553 Mózes 19:29

56 Hammurabi törvényei 6-11. \$S, 15.

572 Mózes 21:16

585 Mózes 24:7

593 Mózes 19:35
} 


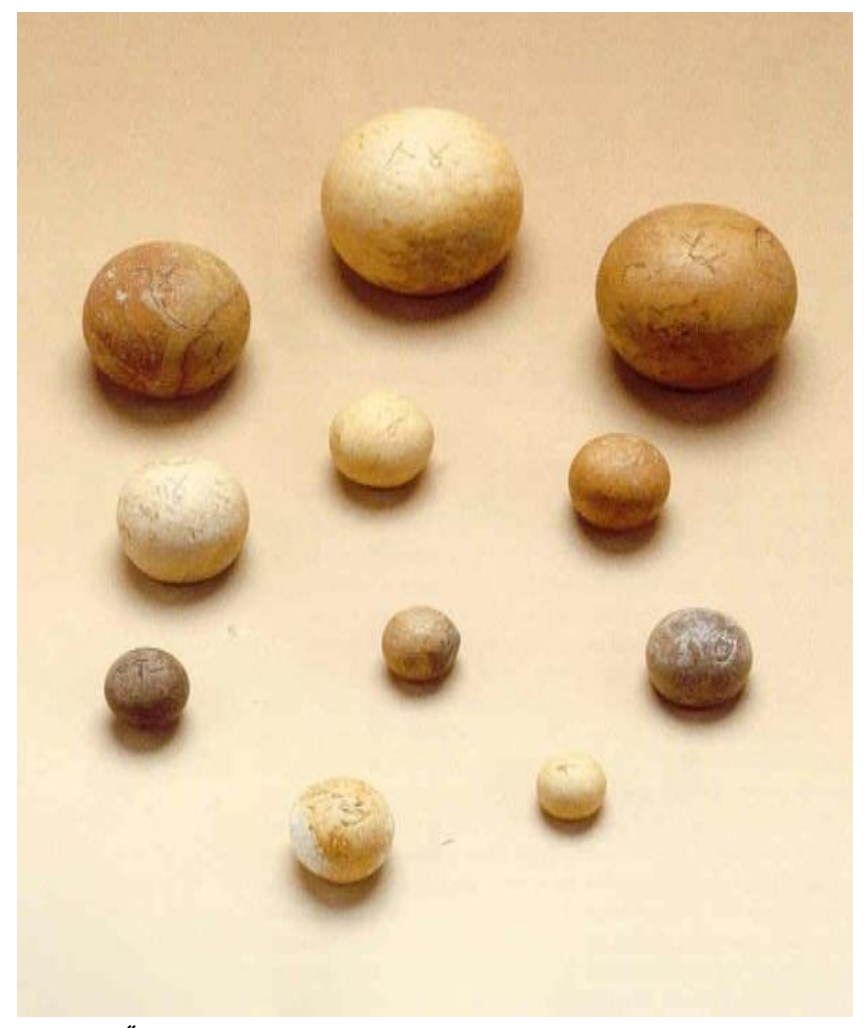

5. kép: Ősi súlymértékek Izraelben termény mérésére alkalmas eszközöket egységesíti: „Ne legyen a te zsákodban kétféle font: nagyobb és kisebb. Ne legyen a te házadban kétféle éfa: nagyobb és kisebb."60 A kétféle mérték és súly tilalma a fogyasztóvédelem korai előfutára volt, hiszen a mérésben történő csalással a vevôt be lehetett csapni, és az eladó a kisebbé tett mércével rejtett árdrágítást ért el, ezzel vevőjét megrövidítette. A próféták az igazságosságot kérték számon kortársaikon, így Ámós ${ }^{61}$ társadalombírálata a csalást sem hagyta szó nélkül: „Mikor múlik el az újhold, hogy gabonát árulhassunk? És a sqombat, hogy megnyithassuk a gabonás házat? Hogy megkisebbitsük a vékát, és megnagyobbitsuk azárát, és hamis mértékeel csalhassunk? Hogy meguegyük a szegényeket pénzen, és a sqükölködöt egy öltö saruért, és eladhassuk a gabona bulladékát?'"62

A Szentírás elítéli nemcsak a gazdasági elit, hanem a politikai hatalommal visszaélését az állampolgárral szemben. Az állampolgár magántulajdonának kisajátítását súlyos következményekkel járó törvénysértésnek tekinti. Szabadság nincsen vagyonbiztonság nélkül. Az állami erőszakkal, az igazságszolgáltatás gépezetével végbevitt rablást egy híres eset, Nábót szőlője kisajátítása példázza (1 Királyok 21.). Az esetben az uralkodó a maga számára kiszemelt ingatlant úgy szerezte meg, hogy tulajdonosát hamis vád alapján kivégeztette és a tulajdont elkobozta. Az anyagi haszonszerzés indítékából elkövetett gyilkosságra és az indíték jelentőségére a X. parancsolatnál térek vissza. Itt csak magát a koncepciós per általi kisajátítást említem a „ne lopj” parancs kapcsán, ami mindenkire egyaránt vonatkozik. A törvényes közhatalomról alkotott európai felfogás szerint a magántulajdontól a polgárt az államhatalom sem foszthatja meg.

\subsection{A jó hírnév védelme}

\section{„IX. Ne tégy a te felebarátod ellen hamis tanúbizonyságot."}

A IX. parancsolat a hamis tanúzás tilalma. A hamis tanú hazugságot mond ${ }^{63}$, ezért a törvény etikai értelme általánosságban a hazugság tilalma. A hamis tanúzás tilalma speciális

\footnotetext{
605 Mózes 25:13-14

${ }^{61}$ Ámós próféta i.e. 745-ig tevékenykedett Izraelben, II. Jeroboám uralma alatti viszonylagos jólét időszakában.

62 Ámós 8:5-6

${ }^{63}$ Példabeszédek 6:19
} 
értelemben a bíróság előtt tett hamis tanúzást mondja ki, tekintettel annak különös súlyára. Hamis tanúzással egy ártatlan ember becsületét, tulajdonát, sőt életét lehet elvenni abban az esetben, ha a bíróság hamis tanúvallomás alapján hozza meg döntését. ${ }^{64} \mathrm{~A}$ parancsolat feltételezi a bírósági hivatal fennállását és döntéshozatali mechanizmusát a vádtól a végrehajtásig.

\subsubsection{A bíróság előtt}

A Tóra egyik jelentős értéke az igazságos és méltányos eljárás iránti követelmény. A bíróság felállításának elrendelésekor megfogalmazza a bírákkal szemben igazságos, pártatlan, megfélemlítéstől és elfogultságtól mentes itélethozatal követelményét. „Bírákat és felügyelöket állits minden kapudba, amelyeket az Úr, a te Istened ád néked, a te törzseid szerint, hogy itéljék a népet igaz. itélettel. El ne forditsd az itéletet; személyt se válogass; ajándékot se végy; mert az ajándék megvakitja a bölcsek szemeit, és elfordítja az igazak beszédét. Igazságot, igazságot kövess, hogy élhess, és örökségül birhasd azt a földet, amelyet az. Úr, a te Istened ád néked." ${ }^{5} \mathrm{Az}$ utolsó passzus kétszeresen megismétli az igazság szót, amit többféleképpen értelmez rabbinikus jogtudomány. Egy lehetséges magyarázata, hogy igazságot úgy kell szolgáltatni, hogy közben maga az eljárás is igazságos. ${ }^{66}$ Rossz eszközzel nem lehet jó cél érdekében tenni az igazságért. A törvény ilyen interpretációjából az következik, hogy helyes ítélet is lehet formai hiba miatt kifogásolható, vagy fordítva, formálisan kifogástalan eljárásban is születhet hibás döntés. A kövess szó a héber szövegben úgy is fordítható, hogy menj utána, vagy akár úgy is, hogy üldözd. Ez azt jelenti, hogy az eljárás indul, az ügyet végig kell vinni, egészen addig, amíg a bírák vagy felügyelők el nem érik az igazságosságot. A felügyelőket mai fogalmainkkal a rendőrséggel helyettesíthetjük be.

A bíróságnak pártatlannak, függetlennek és megvesztegethetetlennek kell lennie. A bírónak személyválogatás nélkül, kizárólag a törvények alapján kell ítéletét meghozni. A törvény előtti egyenlőség azt jelenti, hogy vagyoni helyzetre való tekintet nélkül kell a bírónak a felek számára igazságot szolgáltatnia. Mózes a fenti meghagyásokon túlmenően a bírákat felszólította arra, hogy hallgassák ki az embereket, továbbá, hogy senkitôl ne féljenek, mert az ítélet Istené. ${ }^{67}$ A bírák tehát nem a saját maguk, hanem a Törvény nevében járnak el, ezért jó okuk van arra, hogy megfélemlítés nélkül végezzék munkájukat.

\subsubsection{Hamis tanúzás büntetése}

A tisztességes eljáráshoz fűződő jog elve tükröződik abban, hogy mindkét felet (képviselőiket, tanúikat is) meg kell hallgatni. A tanúkat különösen nagy felelősség terhelte egy olyan korban, amikor a szem-és fültanúk vallomása döntő súllyal esett latba egy-egy döntésben (hiszen a

\footnotetext{
${ }^{64} \mathrm{Pl}$. Nábót szőlője esetében, vö. 1 Királyok 21

655 Mózes 16:18-20

${ }^{66}$ Rav Ási szerint az igazság (cedeq) szó ismétlése azért van, mert kétféle igazságosságot jelent: a törvény szigorú alkalmazását és a józan észen nyugvó kompromisszumot (Jeruzsálemi Talmud, Szanhedrin 32b). A lengyel haszid Rabbi Szimcha Bunim (1765-1827) szóbeli tanítása szerint viszont az idézett vers értelme az, hogy az eljárásnak, melynek során igazságot tesznek, magának is igazságosnak kell lennie. Miærabi ezt így idézi: „Justice for legitimate ends, and justice by legitimate means."

675 Mózes 1:16-17
} 
nyomozáshoz és a bizonyításhoz nem álltak rendelkezésre fejlett technikai eszközök). A hamis tanúzás tilalma magában foglalja a jó hírnévhez füződő jog védelmét. A hamis tanúbizonyság tilalma a hamis vád emelésének tilalmát is jelenti, más szóval a rágalmazást. A tanúskodásról szóló törvény három fontos elemet tartalmaz: egyrészt az ártatlanság vélelme megilleti a vádlottat, másrészt a bizonyítás terhe a vád oldalán van, harmadrészt minimálisan két vagy három tanú egybehangzó vallomása alapján jön létre bírósági ügy.

A hamis tanúra a lex talionis szabálya szerint szabták ki a büntetés mértékét. Figyelemreméltó tény, hogy a mózesi törvény „sžemet szemére’ elve a perrel elérni szándékozott sérelemre is kiterjedt, nem csak a ténylegesen elkövetett testi sértésre. „Ne álljon elo egy tanú senki ellen semmiféle hamisság és semmiféle bün miatt; akármilyen bünben bünös valaki, két tanú squavára vagy három tanú szavára álljon a dolog. Ha valaki ellen gonosz tanú áll eló, hogy pártütéssel vádolja ốt: Akekor álljon az a két ember, akiknek ilyen perük van, az Úr elé, a papok és a birák elé, akik abban az idóben lesznek; És a birák viasgálják megjól a dolgot, és ha hazug tanú lesz a tanú, aki hazugságot szólott a zó atyjafia ellen: Úgy cselekedjetek azzal, amint ö sqándékozott cselekedni az ö atyjafiával. Így tisztitsd ki közüled a gonoszt; Hogy akik megmaradnak, ballják meg, és féljenek, és többször ne cselekedjenek te köpötted ilyen gonosz dolgot. Ne nézz reá szánalommal; lelket lélekért, szemet szemért, fogat fogért, kez̨et kézért, lábat lábért."08

Mindaddig, amíg a vád nem nyer bizonyítást, a gyanúsítottat megilleti az ártatlanág vélelme, nem kezelhetô az elítélttel egy szinten. A bizonyítás terhe pedig a vád oldalán van, ami szintén az ember jó hírnevéhez való jogát engedi érvényesülni.

\subsubsection{Egy tanú nem tanú}

Halálbüntetést kizárólag két, vagy három tanú vallomására volt szabad kiszabni. A tanúknak vállalni kellett az ítélet jogosságáért a felelősséget. „Két tanú vagy bárom tanú szavára halállal lakoljon a halálra való; de egy tanú szavára meg ne haljon. A tanúk kęe legyen elsö rajta, hogy megölettessék, és azután mind az. egész. nép kę̧e. Így tisztitsd ki magad közül a gonoszt.”" Az európai jogi kultúrában a unus testis nullus testis formában összegzett alapelv már a tórai jogban megjelent. Az első követ a tanúknak kellett a vádlottra dobniuk. Erre a joggyakorlatra utal Jézus, amikor egy tetten ért házasságtörő nőt azzal mentett ki vádlói kezéből, hogy felszólította a vádat képviselőket, hogy az vesse rá az első követ, aki nem vétkezett. ${ }^{70}$

\subsubsection{Hallgattassék meg a másik fél is}

A másik fél meghallgatása az igazságos és tisztességes eljárásnak szintén alapvető kritériuma. A latin szállóige formájában rögzült elv (audiatur et altera pars ${ }^{71}$ ) beépült az európai jogi gondolkodásba. „Isten és ember törvényei egyaránt megadták a lehetőséget a másik félnek, hogy védekezzen, ha van valami mentsége (...) még maga Isten sem mondott ítéletet Ádámra azelőtt, hogy felszólította ôt,

\footnotetext{
685 Mózes 19:15-21

695 Mózes 17:6

70 János evangéliuma 8:7

${ }^{71}$ SENECA, Medea 199. Audi alteram pars („halld a másik felet”) formában Augustinus (The two souls 14:22) is használja.
} 
hogy szóljon a védelmére." 72 Az emberpár élhetett a védekezés lehetőségével és beismerő vallomást tehetett. Az ítélethirdetés előtt minden ügyben kérdezni kell, ez indokolja az ügyek nyomozati szakaszát. Az Újszövetség lapjain visszaköszön a tisztességes eljárás elve a korabeli ítélkezés gyakorlatában. „Vajon a mi törvényünk kárhoztatja-é az embert, ba elöbb ki nem hallgatja, és nem tudja, hogy mit cselekssik??'73

Salamon, a bölcs király egy velős mondásban foglalja össze, miért fontos mindkét felet meghallgatni. Mikor szót kap a másik fél, rávilágít az első érvelésének gyenge pontjaira: „Igaza van annak, aki elö a perben; mignem eljö az. ő peresfele és megvizsgálja ơt." 74

\subsection{A magánélet sérthetetlensége}

„X. Ne kivánd a te felebarátodnak házát. Ne kivánd a te felebarátodnak feleségét, se szolgáját, se szolgálóleányát, se ökrét, se sqamarát, és semmit, ami a te felebarátodé." 75

A dekalógus X. cikkelye a privátszféra védelmének etikai elvét fogalmazza meg. Minden ember életideje és tehetsége munkája eredményében és szúkebb és tágabb kapcsolatrendszerében, egzisztenciájában jelenik meg, amelyek földi boldogulásának feltételei. A kívánság, vagyis a másik ember eredményeinek, javainak, állapotának megirigylése mélyen gyökerezik az emberi természetben. Ha cselekedet szintjén nem is megfogható, az irigységre való hajlam felfedése a törvény feladata volt. Pál apostol így vall erről: „a bünt nem ismertem, hanem csak a törvény által; mert a kivánságról sem tudtam volna, ha a törvény nem mondaná: Ne kivánjad." 76 Az irigységet az állami törvény nem szankcionálja, de az isteni törvény fontosnak tartotta, hogy tükröt tartson az ember elé, hogy gátat vessen az irigység által motivált gonosztetteknek. A Szentírás több bűntény hátterében az irigységet, vagy féltékenységet sejteti: az első gyilkosság indítéka az irigység volt. Káin megölte testvérét, Ábelt, mert Ábel áldozata elnyerte Isten tetszését, az övé pedig nem. ${ }^{77}$ Józsefet irigységből kis híján megölték, végül csak eladták rabszolgának a testvérei. ${ }^{78} \mathrm{Az}$ irigység volt Nábót szőlője fondorlatos megszerzése és kivégzése mögött, és a sort még hosszan lehetne sorolni.

A salamoni ítélethozatal közmondásosan bölcs, amelynek kapcsán meg kell említenünk magát a konkrét jogesetet. ${ }^{79}$ Egy házban lakott két nő, mindkettő gyermeket szült. Az egyik megvádolta a másikat, hogy az ráfeküdt a gyermekére, és éjjel, míg ő aludt, ellopta mellőle a gyermekét, és kicserélte a maga halott gyerekére. A másik nő a vádat tagadta, és az élő csecsemőt sajátjának mondta. Az életben maradt újszülött fölött vitatkozó felek között Salamon, Júda királya - színleg - úgy döntött, hogy vágják kétfelé a gyermeket, hogy az asszonyok között egyenlőképpen osszák el. Az egyik nő igazságosnak tartotta a döntést, a másik könyörögni kezdett: inkább odaadja, csak kíméljék meg a gyermek életét.

\footnotetext{
${ }^{72}$ Lásd EYRE bíró megjegyzését (1722) http://www.duhaime.org/LegalDictionary/A/Audialterampartem.aspx

73 János 7:51

74 Példabeszédek 18:17

752 Mózes 20:1-17

76 Róma $7: 7 b$

771 Mózes 4:3-8

781 Mózes 37

791 Királyok 3:16-28
} 


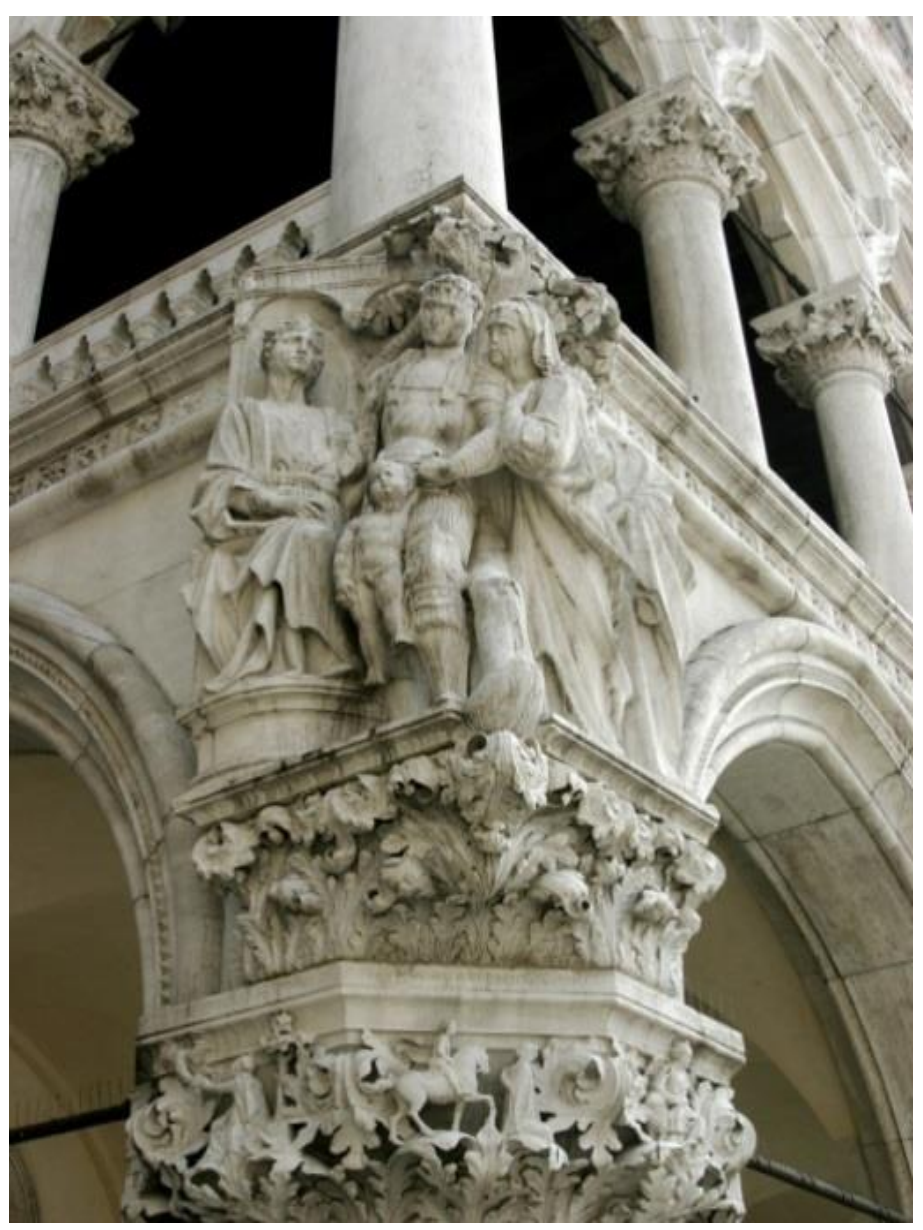

Kettejük közül nyilvánvalóan az volt az ártatlan, aki a csecsemő megkíméléséért fellebbezett, és az volt a tettes, aki nem sajnálta a másik gyerekét, hanem úgy vélte, igazságos, hogy egyiküké se legyen. Salamon ezek után az igazi anyának ítélte meg a gyereket. Mint bíró, egy olyan ügyben, ahol nem voltak tanúk, a per során a „kinek az érdeke?” kérdésre kereste a választ, és a belső indíték kiderítésével tett igazságot. Aki megirigyelte a más gyermekét, az is leleplezte magát beszédével, és az ártatlanul megvádolt asszonyról is kiderült az igazság abból, ahogy reagált. Salamon precedenst teremtő döntése bevonult az európai jogi köztudatba, és az ítélethozatal mércéjét magasra állította, az indítékok feltárásában mély emberismeretről téve tanúságot.

6. kép: Salamon döntése. Velence, dózsepalota

\section{Az ítélőszék régen és ma}

A jogalkalmazók és jogértelmezők felelőssége a törvény eredeti célját szem előtt tartani: vajon az ítélettel okozott esetleges kár mértéke nem haladja-e meg a megítélt cselekedettel okozott erkölcsi vagy anyagi kárt? A törvényesség és az igazságosság időnként elválhat egymástól. Egy ízben arról elmélkedik egy bibliai szerző, vajon a legfőbb Bíró egyetért ilyenkor az ítélettel? „V an-é köz̨e te hozzád a hamisság székének, amely nyomorúságot szerez, törvény szine alatt?’80 - teszi fel a kérdést. Másutt megállapítja, hogy a bíróval maga Isten volt: „véghezvitted itéletemet és ügyemet: az, itélöszé́kben ültél, mint igaz biró." 81

A bíróságok üléstermeinek berendezése hagyományosan egy tekintélyt parancsoló emelvényt is magában foglal. A bírói szék már az antikvitásban az ítélethozatal helye volt, amin a bíróság előtt vitázó felek álltak. A görögül bémá-nak, héberül bimá-nak nevezett emelvény Pál apostol perében a római joghatóság jelképe, ahol a császárhoz fellebbezett. ${ }^{82}$ Az Újszövetség a végső itélet helyét is ítélőszéknek nevezi. ${ }^{83} \mathrm{Az}$ igazságszolgáltatás malmai régen is lassan őröltek.

\footnotetext{
80 Zsoltárok 94:20

${ }^{81}$ Zsoltárok 9:5

82 Apostolok cselekedetei 25:10

${ }^{83}$ Róma 14:10
} 
Jézus egy példázata összehasonlít egy hanyag bírót az igazságos Istennel, akihez panaszukkal fordulnak.

„Volt egy bíró egy városban, aki Istent nem félt és embert nem becsült. Volt pedig abban a városban egy özvegyasszony, és elméne abhoz, mondván: Állj bosszút értem az én ellenségemen. Azpedig nem akará egy ideig; de azután monda ö magában: Jól lehet Istent nem félek és embert nem becsülök; Mindaحáltal mivelhogy nékem terhemre van ez az özvegyasszony, megszabaditom öt, hogy szüntelen reám járván, ne gyötörjön engem. Monda pedig az. Úr: Halljatok, mit mond e bamis biró! Hát az Isten nem áll-é bosszút az ő válasz̨tottaiért, kike ö hozzá kiáltanak éjjel és nappal, ha hosszútürö is irántuk?’"84

Ezzel visszajutottunk kiindulásunkhoz, a Tízparancsolat két kőtáblájához. A hamis bíró egyiket sem tartotta fontosnak: Istent nem félte és az embereket nem becsülte. Ebből a példázatból levezethető, hogy az igaz bíró nyilvánvalóan ellenkezőleg fog tenni, figyelembe veszi mind vertikális, mind a horizontális irányú kötelességét, és nem csak akkor szolgáltat igazságot, ha rájárnak és gyötrik. A történet tanulsága, hogy a lassú ügyintézés is jobb, mintha egyáltalán nem lenne ítélethozatal.

\section{Néhány gondolat a Törvény újszövetségi értelmezése kapcsán 6.1. A názáreti Jézus és a Tóra}

„Akkor hozzá menvén egy az irástudók közül, aki az ö vetekedésöket hallotta vala, és tudván, hogy jól megfelele nékik, megkérdezé töle: Melyik az, elsö minden parancsolatok köröött? Jézus pedig felele néki: Minden parancsolatok között az elsö: Halljad I rráel: Az Úr, a mi Istenünk egy Úr. Szeressed azért az Urat, a te Istenedet teljes szivedböl, teljes lelkedböl, és teljes elmédböl és teljes erödböl. E₹ az elsố parancsolat. A második pedig hasonlatos ebhe₹: Szeresd felebarátodat, mint magadat. Nincs más ezeknél nagyobb parancsolat." 85 A Törvény lényege Jézus szerint Istennek és a felebarátainknak a szeretete.

Az újszövetség a fent idézett két kőtáblát, azaz a Tízparancsolatot két alapvető kijelentésre vezeti vissza, melyek a Tórában vannak, és amelyek lényegét képezik mindezen parancsolatoknak. A názáreti Jézrus törvénytisztelő zsidóként a Tóra betüjét is fontosnak tartotta. ${ }^{86} \mathrm{~A}$ törvényben foglaltakat lényegesebbnek ítélte, mint az ahhoz füzött szóbeli magyarázatot. A jószándékú, de kibírhatatlan emberi rendeleteket élesen bírálta, akár kiskaput jelentettek a törvény eredeti intenciójához képest, mint például a szülők segítésére fordítható pénz templomi ajándékul adása, ${ }^{87}$ vagy épp szigorítást jelentettek, mint a szombaton leszedett pár kalász megevését is munkának minősítő törvényértelmezés. Az első esetben a szülők tiszteletét fontosabbnak tartotta, mint a fogadalmi ajándék adását, a törvény életet támogató rendeltetését tartva szem előtt. A teremtés logikáját látta meg a törvényben, hangsúlyozva, hogy a szombat lett az emberért, és nem fordítva. 88 Szívesen idézte Hóseás prófétát, aki kijelentette, a Törvényadó eredeti szándéka az irgalmasság, és nem az áldozat. ${ }^{8}$

\footnotetext{
${ }^{84}$ Lukács 18:1-7

${ }^{85}$ Márk 12:28-31; vö. Róma 13:8-10; Jakab 2:8-9

${ }^{86}$ Máté 5:17-18

87 Máté 15:1-6

${ }^{88}$ Márk 2:27

${ }^{89}$ Az evangéliumban Jézus Hóseás 6:6-ot háromszor idézi. Máté 9:13-ban és 12:7-ben, a 23:23-ban pedig az ítélet szükségessége mellett utal az irgalmasságra. A görög eleosz̧ a héber chesz̧ed megfelelője, jelentése irgalmasság, szeretet.
} 


\subsection{A kereszténység kezdetei és a Törvény}

A jeruzsálemi ősegyház írásmagyarázatát nem a legalizmus, hanem a messianizmus jellemezte. ${ }^{90} \mathrm{Az}$ első jeruzsálemi zsinat foglalkozott azzal, hogy a nemzetekből származó keresztények mit tartsanak be törvényből. Döntésükben a Noéval kötött szövetségben megfogalmazottakra szorítkoztak, amelyek a nemzetekre vonatkoznak: a monoteizmust és a monogám házasságot követelték meg köreikben. A Tízparancsolatban foglalt egyetemes erkölcsi elvek mellett a ceremoniális törvények közül csak a közegészségügyre tartozó dögevést tiltották, és a vérrel kapcsolatos rendelkezésre emlékeztették őket: „tartózkodjatok a bálványoknak áldozott dolgoktól, a vértöl, a fúlva holt állattól, és a paráznaságtól; melyektöll ha megóvjátok magatokat, jól lesz dolootok." 91 A zsidó ünnepek megtartásában szombat és a vasárnap ünneplésében párhuzamosság figyelhető meg az újszövetségi keresztény gyülekezetekben, melyek többnyire a helyi zsinagógából nőttek ki. A vasárnap tartalma eltért a szombattól, nem a pihenés, hanem a közösségápolás, tanítás volt a célja és mindenekelőtt Jézus feltámadásának ünneplése. ${ }^{92} \mathrm{Az}$ Ószövetség recepciója az Újszövetségen keresztült történt meg az európai nemzetekben és hatotta át a nyugati civilizációt. Ez azt jelenti, hogy mózesi Törvényből csak annyit vettek át, amennyit az apostolok követendőnek tartottak. Jézus Krisztus követői a mózesi törvényt annak univerzális erkölcsi küldetésében ragadták meg és terjesztették.

\subsection{A törvény és az evangélium}

„Ám a törvény szent, és a parancsolat szent és igaz és jó."93 Szent Pál, a nemzetek apostola írásaiban rendszeresen foglalkozik a bűn, a törvény és az igazság problematikájával. Jelen írásban csak a jogrend szempontjából legfontosabbra szorítkozva, ez nézete úgy összegezhető, hogy a jó nincs a törvénynek alávetve, hanem a törvény fölött áll. Remélte, hogy az evangélium hirdetése következtében nagy tömegekben válhat a törvény benső iránytűvé, és olyan életmódban ölt testet, ami semmilyen törvénnyel nem ütközik. „Tudjuk pedig, hogy a törvény jó, ha valaki törvényszerúen él vele, tudván ą̧, hogy a törvény nem az igazért van, hanem a törvénytaposókért és engedetlenekért, az istentelenekért és bünösökért, a latrokért és fertelmesekért, az atya- és anyagyilkosokért, emberölökért. Paráznákért, férfifertöztetókért, emberrablókért, hazugokért, hamisan eskïvökért, és ami egyéb csak az egészséges tudománynyal ellenkęik, a boldog Isten dicsöségének evangéliuma szerint, mely reám bizatott."94

Pál apostol - a már említett ítélőszék előtt állva - Porcius Festus előtti védőbeszédében meggyőződéssel vallotta, hogy a próféták munkássága az evangéliumon keresztül felvilágosítja a nemzeteket. „De Istentöl segítséget vévén, mind e mai napig állok, bironyságot tévén mind kicsinynek, mind nagynak, semmit sem mondván azokon kivül, amikeôl mind a próféták. megmondották, mind Móres, hogy be fognak teljesedni: Hogy a Krisztusnak szenvedni kell, hogy mint a balottak. feltámadásából elsó, világosságot fog birdetni e népnek és a pogányoknak."

A nemzetek és a Tóra viszonyát abban látta, hogy a törvény Isten ajándéka Izraelnek, és a

\footnotetext{
${ }^{90}$ Legjobb példa erre Simon Péter három nyilvános beszéde az Apostolok cselekedeteinek 2-4. részében.

91 Apostolok cselekedetei 15:29

${ }^{92}$ Apostolok cselekedetei 20:7; Róma 14:6

${ }^{93}$ Róma 7:12

941 Timoteus 1:8-11
} 
bűn megismerésére való. A törvény és a prófétai írások célja elvezetni minden embert a Messiáshoz, aki a belé vetett hit által igazzá tudja tenni a bủnöst: „Mivelhogy egy az. Isten, aki megigarítja a zsidót hitböl és a pogányt hit által." 95 Izrael küldetése a nemzeteket felvilágosítani, ezt a küldetését maga részéről az evangélium terjesztésével töltötte be.

\subsection{Az Újszövetség és az államhatalom}

A Római Birodalom vagy akár barbár királyságok alattvalójaként a keresztények és zsidók ugyanúgy a polgári közigazgatás alá tartoztak, mint a görög, római vagy más vallású emberek. Az Újszövetség tudomásul veszi az állami felsőbbséget, és a hatóságoknak való engedelmességet hirdeti, amíg az nem ütközik Isten parancsaiba. ${ }^{96}$

Pál apostol a Rómaiakhoz írt levél 13. részében rakta le a keresztény államelmélet alapjait. A szolgáló hatalom fogalmát ennek az alapvetésnek köszönhetjük. „Minden lélek engedelmeskedjék a felsö hatalmasságoknak; mert nincsen hatalmasság, hanem csak Istentöl: és amely hatalmasságok vannak, az, Istentöl rendeltettek. Azért, aki ellene támad a hatalmasságnak, az. Isten rendelésének támad ellene; akik pedig ellene támadnak, önmagoknak itéletet szereznek. Mert a fejedelmek nem a jó, hanem a rossz cselekedetnek rettegésére vannak. Akarod-é pedig, hogy ne félj a hatalmasságtól? Cselekedjed a jót, és dícséreted lesz attól. Mert Isten szolgája ö a te javadra. Ha pedig a gonosz̨t cselekszed, félj: mert nem ok nélkül viseli a fegyvert: mert Isten szolgája, bosszuálló a haragra annak, aki gonoszt cselekszilk." 97

A fenti szakasz rávilágít az Isten szuverenitásából levezetett állami szuverenitás fogalmára. Az Isten által az államra ruházott hatalom nem autonóm, hanem delegált hatalom, aminek erkölcsi küldetése van. Feladata, hogy üldözze a bűnt és jutalmazza a jót, azaz: a törvényszegőoön bosszút álljon, de a törvénytisztelők félelem nélkül élhessenek.

Ha fordítva történik, akkor „nem beszélhetünk arról, hogy azérintett vezetöt vagy rezsimet valamiféle isteni végzés emelte pozícióba, vagy tartaná ott. Fontos különbséget tenni tehát az. Istentöl eredö hatalmi jogkör és annak betöltöje között. A Biblia sžerint fontos, hogy legyen hatalmi/ tekintélyi rend, mert különben anarchia lenne, beköszöntene a lelkiismereti korszakot meghatározó <ember embernek farkasa> állapot, ugyanakkor elitélendó, ha a hatalommal visszaélnek, mert a <fejedelmek, nem a jó, hanem a rossz, cselekedetnek, rettegésére vannak.>"98 A nemzetek és birodalmak jogrendjét az Újszövetség nem tekinti szakrálisnak, hanem olyannak, ami javításra, humanizálásra szorul, hogy a hatalom mindinkább a közjót szolgálja.

\section{7. Összefoglalás}

A Biblia, azon belül a Tóra a zsidóság és a kereszténység közös kultúrkincse. Számos jogelv, amely formálta a nyugati civilizációt, a mózesi Törvényben gyökerezik. Ezeket a kereszténység is becsben tartotta, és a szabadságjogok irányába továbbfejlesztette. Ezen elvek: az emberi méltóság minden egyént megillető tisztelete, az emberi élet értéke és védelme, a család és a magántulajdon védelme, a jó hírnévhez fűződő jog, a privátszféra tisztelete. A jog területén a független bíróság, az igazságos

\footnotetext{
${ }^{95}$ Róma 3:30

${ }^{96}$ Róma 13:1-3; Apostolok cselekedetei 5:29

${ }^{97}$ Róma 13:1-4

${ }^{98}$ MÉSZÁROS, Bibliai államelmélet 4.
} 
és pártatlan eljárás, a törvényes rend és közbiztonság fogalmát, a hatalmi ágak elválasztásának és a jogállamnak az eszményét köszönhetjük a máig releváns tórai elveknek.

\section{Felhasznált források és irodalom}

AugustinE: Writings Against the Manicheans. The two souls. Christian Classics Ethereal Library. http://www.ccel.org/ccel/schaff/npnf104.iv.vi.xv.html (letöltés: 2017. 10. 04.)

BEN-SAsson, H. H. et al. (szerk.): A History of the Jewish People. Cambridge - Massachusetts 1976

Biblia Hebraica StUTTGarTensia. Stuttgart 1984

CONNER, K. Jr.: The Foundation of Christian Doctrine. Chichester 1988

GeSenius’ Hebrew and Chaldee LeXicon to the Old Testament SCRIPTURes. Michigan 1994 (reprint, 1. kiadás: 1857)

HAMMURABI törvényei (ford. KMOSKÓ Mihály). Kolozsvár 1911 http://mek.niif.hu/07200/07287/07287.pdf

(letöltés: 2017. 10. 01.)

JOHNSON, Paul: A zsidók története. Budapest 2005

MCMILLAN, S. I. (MD): Elekerülhető betegségek. Ellenségeskedés vagy szeretet, stress vagy békesség. Egy orvos érvelései a Biblia jelenlétében. Bissingen é. n.

MÉSZÁros István: Bibliai államelmélet. Budapest 2007

MizRAHI, M. Maurice: Justice. Torah Discussion on Shofetim, Springfield 2006

http://images.shulcloud.com/618/uploads/PDFs/Divrei_Torah/justice.pdf (letöltés: 2017. 10. 04.)

NOVUM TESTAMENTUM GRAECE. Stuttgart 1983

SENECA: Medea. Edited with Introduction, Translation, E-Commentary by A. J. BoYLE, Oxford 2014

SZENT BiBLIA (ford. KÁROLI Gáspár). Budapest 2004 
Herger Csabáné

DOI: 10.15170/DIKE.2017.01.01.03

habilitált egyetemi docens

PTE ÁJK

\section{Szakrális kontra szekuláris értékek a polgári modernizáció korában}

\section{Sacral contra Secular Values in the Period of the Civil Modernization}

European legal culture is primarily rooted in Roman-Germanic heritage and Jewish-Christian revelation, although it is not intact from Asian and islamic effects. As opposed to the absolute values of the Jewish-Christian culture, from the time of the French Revolution relativism concerning good and bad, right and wrong is trendy. Absolute sacral values and relative secular values differentiated from each other only at the early time of the civil modernization. However when the public life passed into profane, became this distance only exceptional. The combination and rivalry of sacral and secular values are typical up to the present day in Europe.

Keywords: sacral values, secular values, civil modernization, Jewish-Christian legal culture

\section{Szembe állíthatók-e a polgári modernizáció korának szakrális és a szekuláris értékei?}

A modern állam az újkortól kezdődően a közélet formájára illetve az államélet egészére vonatkozó általános megjelölés. Maga a szó elsősorban időbeliséget fejez ki, a tartalma azonban ennél jóval összetettebb. Az összehasonlító alkotmánytörténet-tudomány módszereivel a modern állam fogalmát - annak lényegét tekintve - az alábbiak szerint lehet meghatározni.

Ha modern államról beszélünk, elsősorban arra a külöbségre gondolunk, amit a keleti, az antik és a középkori államokkal szemben ez megjelenít. Jellemző, hogy az állam kategóriát a legfiatalabb típustól, a modern államtól kölcsönözzük a régebbi típusok leírásához. Maga a modern állam három szakaszban formálódott ki. Az első stádiumban a korábbi, középkori hierarchikusfeudális államból a modern állam ideáltípusára jellemző vonulatok jelentek meg úgy, hogy sokáig még felismerhetők voltak a középkori vonások is. Ez a korai szakasz tehát a modern állam kiépítésének korszaka volt, amely időben a francia forradalomig, 1789-ig tartott. A második szakaszban már többnyire az ideáltípus teljessége érvényesült. Ezt nevezzük a modern állam virágkorának, ami lényegében a 19. századot ölelte fel. A harmadik szakaszban ezzel szemben már a leépülés nyomai tûntek fel, amikor is az ideáltípus újabb tendenciák megjelenésével lassan szétfoszlott. Ezzel tehát a modern állam időbeli határai nyilvánvalóvá váltak: a modern állam kifejezést a nyugati politikai és jogi kultúra területén a középkor végétől számítva a 20. század elejéig, többnyire az I. világháború végéig szokás alkalmazni.

A modern állam ideáltípusát úgy lehet megragadni, ha megvizsgáljuk ennek a három szakasznak azokat a tendenciáit, amelyek együttes hatása következtében a modern állam megjelent. Ezzel a módszerrel négy különböző absztrakció különíthető el, amelyek egymást kölcsönösen kiegészítették. Elsőként a szuverén abszolút állam jelent meg, majd a viszonylag kötött, polgári- 
kapitalista társadalmi és gazdasági formációval rendelkező ún. kereskedőállam. Ezeket harmadikként az individuum személyes szabadságának jelszavát hangsúlyozó liberális jogállam követte, majd a sort a nemzetállam zárta le az előző tendenciákat is átfogva, demokratikus irányultsággal. ${ }^{1}$

A polgári modernizáció korának értékeit vizsgálva - bár mind a négy absztrakciónak voltak karakterisztikus értékei - elsősorban a liberális jogállam jelentőségét kell kiemelni.

$\mathrm{Az}$ abszolút állammodell esetében a lényegi újdonság a világi hatalom teljességére vonatkozott. Egyrészt a szuverén abszolút állam az egyházi gyámkodás alól felszabadulva világi államként lépett a középkori monarchiák helyére, másrészt a hatalom teljessségét olyan értelemben is megjelenítette, hogy az uralkodó hatalma és felsőbbsége saját jogán alapult, szemben a nép által az uralkodóra átruházott hatalom elméletével, amely - római gyökerekből táplálkozva - a középkorban is jelen volt. Az állam ezzel kilépett a korábbi közösségi viszonyokból és önmaga meghatározójává vált. Ennek előfeltétele belülről az államhatalom kizárólagossága, kívülről pedig függetlensége volt.

A viszonylag kötött, polgári-kapitalista társadalmi és gazdasági formációval rendelkező ún. kereskedóállam a modern államnak a gazdasági életben betöltött helyét jelenítette meg, amelyben a föszerepet a merkantilizmus játszotta. A kapitalizmust nem az állam hozta létre, de az állammal kapcsolatban, annak szolgálatában és védelme alatt vált mértékadó gazdasági formává. Korai szakasza a merkantilista gazdaságpolitikával kezdődött el, míg virágkora egybeesett a modern állam virágkorával, azaz a 19. századdal. Kétség nélkül mondhatjuk tehát, hogy erôsen kötődött a modern államhoz és annak polgári társadalmi rendjéhez.

Az utolsóként megjelent absztrakció, a nemzetállam kollektív-szövetségi szerkezete a liberális jogállammal szemben abból adódott, hogy a nép egy egységet képezett és ez az egyesülés nem uralmi, hanem szövetségi formában történt meg. A nemzetállamok alapja az az összetartozásérzés volt, amely a közös származásból, nyelvből, kultúrából és történelmi emlékezetből táplálkozott, bár a kulturális nemzetállam helyett - amely csak nemzeti és etnikai kisebbségekkel nem rendelkező államban valósulhatott volna meg - az európai államokban rendszerint voltak (és vannak is) kisebbségek. Ennek következtében csakis a politikai nemzetfogalomnak lehetett realitása, amely szerint a hangsúly a nemzettel való azonsuláson, nem pedig a származáson volt.

A tanulmány tárgya szempontjából a modern állam ideáltípusának legfontosabb (időben többnyire harmadikként kibontakozó) absztrakciója az individuum személyes szabadságának jelszavával operáló liberális jogállam volt, amely nemcsak az objektív jogrend védelmezője, hanem az ember és a polgár szubjektív igényeinek őre is volt mind a magánszféra, mind a közélet területén. Eszköze a racionális törvényi jog volt, amely a 18-19. század fordulójára többnyire előtérbe került az eddigi szokásjoggal és bírói precedensjoggal szemben. A felvilágosult abszolutizmus már jogegységesítésbe fogott, melynek eredményei mellett a legisták recipiált római joga a monarchikus szuverenitás védelmezőjének bizonyult a forradalom elôtti Franciaországban illetve az alattvalók magánszférájának javát szolgálta a német térségben. Ezt követően az individualizált jogi racionalizmus termékeiként jelentek meg a nagy természetjogi kódexek, többek között a porosz ALR (1794) és francia Code Civil (1804). Ezzel egyidőben átalakult és egyben bürokratizálódott az

\footnotetext{
${ }^{1}$ A négy absztrakciót lásd bővebben HiNZE, Wesen und Wandlung 470-496.
} 
igazságszolgáltatási rendszer is. Fontos szólni az alattvalók szubjektív közjogi jogainak elismeréséről és védelméről is.

Ez a tendencia az angol polgári forradalommal vette kezdetét, majd az Amerikai Egyesült Államok alkotmányával (1787) és annak első tíz kiegészítésével (Bill of Rights 1791) teljesedett ki. A klasszikus szabadságjogokat ezek után minden modern alkotmány alapjogként ismerte el. A szabadságjogok mellett a polgári szabadság másik tartópillére a képviseleti alkotmány volt, amelyben az államhatalom különböző funkcióit a törvényhozó, a végrehajtó és az igazságszolgáltató hatalmat egymástól elválasztották. A jogállam mindezeket számba véve a jogcél megvalósítását, a törvények szerinti kormányzást jelentette és jelenti. A gyakorlatban azonban egyetlen kormányzat tevékenysége sem korlátozódhatott a törvények egyszerú végrehajtására, hiszen mindennapos jelenséggé vált, hogy a végrehajtó hatalomnak döntést kellett hozni. Ezért a pártalapú kormányok esetében feltétlen szükségesnek bizonyult az is, hogy e döntéshozatal ellenőrzésére független közigazgatási bíróságot intézményesítsenek. A liberális jogállam lényegét ezért - legyen szó alkotmányos monarchiáról vagy köztársaságról - abban látjuk, hogy az egyén védelmet élvez a rendőrséggel és a közigazgatási hatóságok aktusaival szemben.

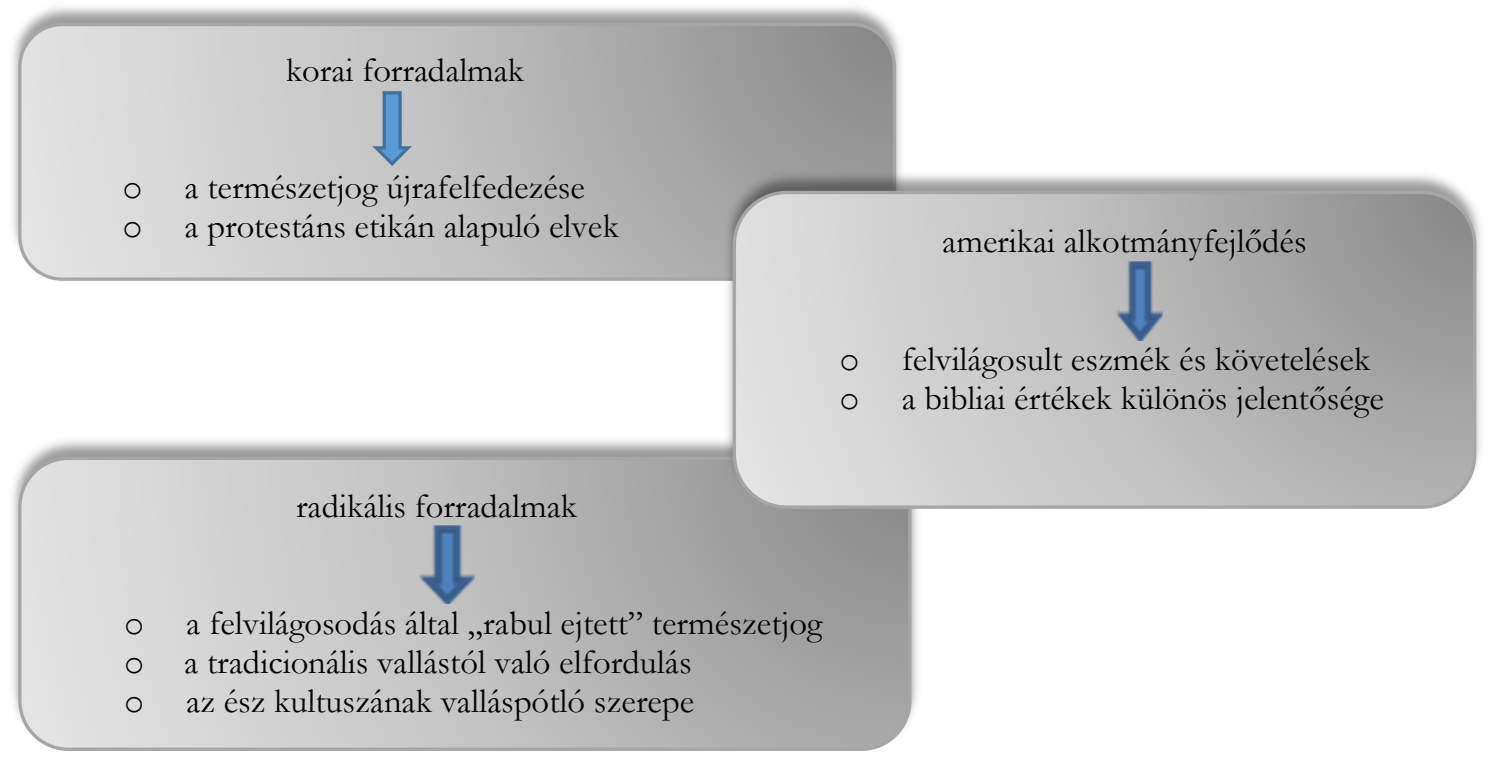

1. ábra: A polgári modernizáció eszmetörténeti modelljei

A modernizáció következő színhelye Anglia és az Amerikai Egyesült Államok után Franciaország volt, ahol 1789-ben a felvilágosodás által meghódított természetjog, az ún. észjog szolgáltatott ideológiai alapot a radikális forradalomhoz, az abszolutizmus felszámolásához és az Emberi és Polgári Jogi Nyilatkozat (1789) elveire hivatkozva a polgári jogegyenlőség elvén álló jogrendszer kiépítéséhez. Európa középső és keleti része csak jelentős késéssel, a 19. század derekán volt képes a modern polgári állam kiépítéséért harcba szállni, bár ekkor még német és osztrákmagyar területen is várni kellett az áttörésre: a német egység létrejötte (1871) illetve az osztrákmagyar kiegyezés (1867) volt az, ami megnyitotta az utat a modernizáció előtt. Ezek a polgári átalakulás és modernizáció szempontjából megkésett államok az eszméket túlnyomó részben nyugatról exportálták: a kor jogforrásai és a politikai irodalom tükrében egyértelmûen állítható, 
hogy a gondolkodók és politikusok „vigyázó szemüket” nemcsak Párizsra vetették, hanem az amerikai eredményekre is tekintettel voltak. Ennek következtében nem csak az elméleti múvekben, hanem a konkrét jogforrásokban is világosan kimutatható, hogy mikor használt a jogalkotó angol, amerikai, francia vagy más megoldást modellként illetve ezeket hogyan igazította hozzá az adott állam társadalmi viszonyaihoz és uralkodó értékfelfogásához. ${ }^{2}$

A fejezetcímben feltett kérdésre ezért a válasz nemleges: a szakrális és a szekuláris értékek csak a polgári modernizáció korai szakaszában különültek el világosan. A közélet világivá válását követôen ez a távolságtartás kivételessé vált, és többnyire csak a felekezetükhöz erősen kötôdő valamint annak hivatalos véleményét képviselő közéleti szereplőknél jelent meg. A jogforrásokban ekkor egyértelmű szembenállás már egyáltalán nem volt jellemző, csupán a keveredés kisebb vagy nagyobb mértékét lehet kimutatni.

\section{A szakrális és a szekuláris értékek párhuzamossága}

Az európai jogi kultúra zsidó-keresztény értékei körében Rezső́házy Rudolf az egyetemes értékek, a hívők közösségének értékei és a hívők közösségén túl terjedő értékek között tett különbséget. ${ }^{3}$ Kifejtette, hogy a zsidó-keresztény jogi kultúrában „megtaláljuk azokat az egyetemes normákat, amelyek minden nagy civilizációban föltünnek. Ezek az egyetemes normák minden társadalom alapját képezik. Így van ez. Mózes típparancsolatával. Az ebben fölsorolt értékeke nélkül a közösségi élet ellehetetlenülne: az élet védelme (ne ölj), a tulajdon fontossága (ne lopj), a család és a más élettársának tisztelete, a nemi ösztön szabályozása. Ezeket az általános érvényü elveket példázza a bíres aranyszabály is: Ne tedd másokeal azt, amit nem szeretnél, hogy veled tegyenek. Másrészt vannak tipikusan keresz̨tény és csak az evangéliumokban található értékek. Amikor Jézus arra bivja tanitványait, hogy legyenek tökéletesek, mint abogy mennyei Atyánk tökéletes, mély bivönek. kell lenni ahboz, hogy valaki ebhez az ideálhoz. közeledjék. Amikor a kapott ütés után a másik orcát kell nyújtani, csake a bit adhat bátorságot abhoz, hogy az ember igy cselekedjék. Szeresd ellenségeidet - ime egy magatartás, mely meghaladja az átlag egyén erejét. A hegyi beszéd által ajánlott erények ellentétesek a közvélemény által elfogadott szokéasokkal: a szegénység, a szelidség, a könnyek, az igazságra vágyás, az irgalom, a jósziviuség, a békee.

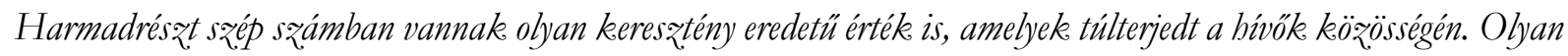
általános európai értékeekeé lettek, melyeket mindenki elfogad, legyen az bivó, bitetlen, agnosz̨tikus, közömbös vagy akár a vallás ellensége. Még egy európai ateista is európai módon tagadja Istent." 4

Bár Rezsoóháay negyvenhét értéket vizsgált a fenti hármas csoportosítás szerint, az alábbiakban (a teljesség igénye nélkül) csak az európai jogfejlődés szempontjából különösen fontos értékekről lesz szó, melyek a polgári modernizáció korában jellemzően a zsidó-keresztény kultúrához kötődő természetjogi felfogás értékkatalógusában és a szekularizált szemléletet tükröző felvilágosult észjogi értékkatalógusban is megjelentek, bár különböző elméleti indokolással, de többnyire azonos lényeges tartalommal. Ezek az emberi méltóság fogalma, a jogegyenlőség elve valamint a szabadságeszmény és ennek következtében a tolerancia követelménye.

\footnotetext{
${ }^{2}$ KAjtÁr - Herger, Egyetemes állam- és jogtörténet 133-149.

${ }^{3}$ Herger, A megélt kor 95.

${ }^{4}$ Herger, A megélt kor 95.
} 


\subsection{Az emberi méltóság}

Az emberi jogok első generációjaként megjelent klasszikus szabadságjogok alapját az emberi méltóság (dignitas humana) képezi. Az élőlények között egyedül az ember rendelkezik hármas, testilelki-szellemi integritással, ami személlyé teszi. A személy képes arra, hogy életét saját belátása szerint, értelmével maga határozza meg és alakítsa. A személy méltósága az emberiség történetében elsőként a zsidó vallásfilozófiában jelent meg azzal, hogy a ius Divinum a szabad akarattal, Isten képére teremtett emberiség minden tagját méltósággal ruházta fel. ${ }^{5} \mathrm{~A}$ görög szofisták is egységes csoportként értelmezték az emberiséget: egyrészt azt állították, hogy a természetjog szerint nincs különbség ember és ember között, másrészt úgy gondolták, hogy ha a valóságban mégis létrejött bármiféle különbség, az csak erôszak és hatalom következménye lehet. Arisztotelész. ezzel szemben azt állította, hogy természettôl fogva vannak szabadok és szolgák, és a szolgaság ez utóbbiak esetében hasznos és jogos. Jusztinianosz mintegy 800 évvel később úgy vélte, hogy az emberek szabadon születnek és a rabszolgaság ellentétes a természetes renddel - bár ez utóbbi intézményt a jusz̧tinianosz̨i jog sem számolta fel. A középkori egyházjogba az emberi méltóság fogalma a zsidó vallásfilozófiából került át.

Aquinói Szent Tamás azt állította, hogy Isten elôtt minden ember egyenlő és Isten országának polgáraként veleszületett méltóság hordozója, ez a méltóság pedig elidegeníthetetlen és sérthetetlen értékként természetes korlát a világi hatalom minden beavatkozásával szemben. Az emberi méltóság fogalmát a teológiából a világi jogtudományba a humanista Pico della Mirandola exportálta. Ezzel az emberi méltóság az ember személyiségének központi részeként az ember és az állam közötti viszonyban kulcsfogalommá vált. ${ }^{6} \mathrm{Az}$ európai jogtudományban a személy ontológiai adottságának elismerése számottevő mértékben az újkor kezdetén jelent meg. Ezzel az embert a közösség tagjaként megillető jogok és kötelezettségek háttérbe tolódtak (szekunder szerep), míg az embert egyénként megillető jogok és kötelezettségek elsődleges értelmet (primer szerep) nyertek.7 Az emberi méltóság ekkortól kezdve mindenkor az emberi jogok alapját képezte és képezi, bár a polgári modernizáció korának jognyilatkozataiban illetve alkotmányos dokumentumaiban maga az emberi méltóság kifejezés jellemzően nem szerepel.

Különösen fontos az amerikai Bill of Rights (1791), azaz az Amerikai Egyesült Államok alkotmányának (1787) első tíz kiegészítése, melyek közül a IX. cikkelyben rögzített generális klauzula szerint a Bill of Rights jogkatalógusa nem taxatív felsorolás, hanem azt a „nép által élvezett jogok" egészítik ki, melyek (többek között az emberi méltóság, a becsülethez vagy amagánélethez való jog) a commmon law alapján védendők, akár a konkrétan nevesített jogokkal szemben is. ${ }^{8} \mathrm{~A}$ dignitas bumana fogalmát korunk Európája a zsidó-keresztény jogi kultúrából (kánonjogi közvetítéssel) örökölte. Ezt tagadni felesleges, de egyben lehetetlen is.

\footnotetext{
${ }^{5}$ I Mózes 1:7, 26

${ }^{6}$ HaLmai, Az emberi jogok igazolása 20-37.

${ }^{7}$ NiETLISPACH, Grundlagen der Freiheitsrechte 9.

${ }^{8} \mathrm{http}: / /$ www.verfassungen.net/us/verf87-i.htm
} 


\subsection{A jogegyenlőség elve}

A szabadságjogok érvényesülési feltételei között a liberális jogállam elméleti megfogalmazói a jogegyenlőség elvét és az ún. negatív szabadság fogalmát jelölték meg. Ez utóbbi John Stuart Mill (1806-1873) szerint azt jelenti, hogy az állam kényszert állampolgáraival szemben egyetlen esetben alkalmazhat csak: akkor, ha ez más állampolgár jogsérelmének a megakadályozását szolgálja. Ahogy ezt az Emberi és Polgári Jogi Nyilatkozat már megfogalmazta: „A szabadság abban áll, hogy mindent megtehetünk, ami másnak sem árt, igy tehát minden ember természetes jogainak gyakorlása csak olyan korlátba ütközhet, amelyek a társadalom más tagjainak biztositják, hogy ugyanezekekel a jogokkal élhessenek. Ezeket a korlátokat csak a törvény állapithatja meg." (IV. cikkely) ${ }^{9}$ Ezek szerint a szabadság (liberalizmus) és a szabadosság (libertianizmus) élesen elkülönül egymástól. Míg az utóbbi korlátnélküliséget jelent, addig a szabadságnak van határa, hiszen addig terjedhet csak, amíg más ember jogát nem sérti. A Nyilatkozat szerint a törvények feladata ezeknek a korlátoknak a meghatározása (V. cikkely), tehát a nemzetszuverenitás elvén álló törvényhozó hatalom jogosult egyedül arra, hogy ezt megtegye (VI. cikkely). Mindehhez hozzátartozik az is, hogy a Nyilatkozat rögzítette: amit a törvény kifejezetten nem tilt, az szabad (V. cikkely). Francia mintára ez az elv az Elbától nyugatra a polgári modernizációval általánossá vált, míg az Elbától keletre ennek ellentéteként az ún. autokratilus jogelv még hosszú ideig továbbélt, azaz amit a törvény kifejezetten nem engedett meg, azt tilosként fogadták el. ${ }^{10}$

A polgári jogrendszer kiépítésére az egyes államokban akkor került sor, amikor a modern államépítési alapelvek a gyakorlatban már érvényesültek és lehetőséget biztosítottak a jogrendszer fejlesztéséhez. Ennek általános menete az addigi jogi partikularizmus felszámolásával az egységes jogrend megteremtése volt. Joggal nevezhetjük ezért a polgári korszakot a jogfejlődés tekintetében a kodifikációk korának - legalábbis a kontinentális jog területén. Mivel a középkori illetve feudális jogban a nyílt jogegyenlőtlenség elsősorban a társadalmi állás, ezen túl pedig a nemi és vallási hovatartozás következtében a magánjogban, a büntetőjogban és kisebb mértékben az eljárásjogok területén is megjelent, polgári jogrend kiépítésére csakis úgy kerülhetett sor, hogy ezeket a különbségeket felszámolták.

A modern államépítési elvek körében a jogtudomány a jogegyenlőséget a klasszikus szabadságjogok érvényesülési feltételeként értelmezte és értelmezi, ez azonban az alkotmányjogon túl a többi jogág területén is igaz: a jogegyenlőség abból fakad, hogy minden embert emberi méltóság illet meg és ugyanazokkal a jogokkal jön világra, ez pedig kizár minden társadalmi állásra, nemre, vallásra, etnikai hovatartozásra vagy más tényezőre alapozott jogszabályi diszkriminációt. $\mathrm{Az}$ amerikai Függetlenségi Nyilatkozat ezt így fogalmazta meg: „Mi equeket az igazságokat magától érthetönek tartjuk, hogy minden ember egyenlönek van teremtve". A francia Emberi és Polgári Jogi Nyilatkozat ezzel szemben azt hangsúlyozta, hogy minden ember „szabadnak és egyenlönek sqületik”. ${ }^{11} \mathrm{Ez}$ a különbség csak a két nyilatkozat eltérő eszmetörténeti hátterére utalt, a lényeg azonban ugyan az volt: a teljes diszkriminációtilalom.

Anélkül, hogy a modern eljárásjogi elvek között a jogegyenlőség elvét a modernizáció-kori

\footnotetext{
${ }^{9}$ Mika Sándor fordításában lásd http://mek.oszk.hu/00000/00056/html/228.htm

${ }^{10}$ PÉTER, Volt-e magyar társadalom 5-8.

${ }^{11} \mathrm{http}: / /$ www.verfassungen.net/us/index.htm
} 
jognyilatkozatok és kódexek expressis verbis nevesítették volna, a formális jogegyenlőségnek az eljárásjogi szabályokban is érvényesülnie kellett és kell, ahhoz, hogy azok értelmezhetőek legyenek. A magánjogi és büntetőjogi természetjogi kódexekben azonban kifejezetten megjelent a jogegyenlőség követelménye, és a részletszabályokban is törekedtek annak érvényesítésére. Ezt azonban - többnyire a tradicionális gyökerek maradandósága miatt - nem feltétlenül sikerült megvalósítani.

A magánjog területén hosszan sorolhatnánk a jogegyenlőség elvével szembeni hiányosságokat a bajor CMBC-ben (1756), a porosz ALR-ben (1794), az osztrák OPTK-ban (1812) és a Code Civil-ben (1804), de a következetes megoldással a kodifikáció második hullámához tartozó pandektista törvénykönyvek is adósok maradtak. Így a munkaadó és a munkavállaló közötti jogviszony kellő szabályozása, a női jogegyenlősítés (elsősorban a házas nô személyi és vagyoni jogi önállóságának kérdése) és a házasságon kívül született gyermekek hátrányos helyzetének a felszámolása is a 20. századra, többnyire annak második felére maradt. Sajátos, hogy a középkori jogban az izraelita vallás a jogképességet és a cselekvőképességet is befolyásoló tényező volt, de a polgári modernizáció korának természetjogi kódexei sem feltétlenül valósították meg a zsidók polgári jogegyenlősítését. A francia forradalmi-kori emancipációval szemben az Elbáttól Keletre a reformkorban kezdődő, lépcsőzetes jogkiterjesztés történt (amit a polgári demokráciák leépülésének korában, a két világháború közötti időszakban a fokozatos jogkorlátozás, majd jogfosztás követett). Míg ez igaz az osztrák örökös tartományok zsidó lakosságára is, az OPTK személyi jogi része - a bécsi udvar elkötelezett felvilágosult természetjogászainak, elsősorban Sonnenfelsnek, majd később Zeillernek köszönhetően - 1812-ben már rögzítette, hogy az állam területére lépő rabszolga ipso iure felszabadul. ${ }^{12}$ Tegyük hozzá, rabszolgája nem igen akadt a gyarmatokkal nem rendelkező Habsburg Birodalomnak, így könnyen tehetett - a felvilágosult elveknek megfelelő - gesztust, miközben a saját problémáit nem tudta megoldani.

A rabszolgák jogalannyá válása (állampolgárság kérdésén és a politikai jogegyenlősítésen túl a polgári jogi jogegyenlősítés) azért kulcsfontosságú a modern államok történetében, mert ennek a területnek a modernizálásával sokáig adósak maradtak egyes államok: az olcsó munkaerőhöz fűződő gazdasági érdek és a faji előítélet felülírta a szabadság és a jogegyenlőség iránt elkötelezett társadalmak illetve a gazdasági-politikai elit szándékait. A néger rabszolga-kereskedelem megszüntetése és a rabszolgamunkaerő alkalmazása a különböző területeken több szakaszban, hosszabb idő alatt valósult meg. Angliában 1807-ben, az angol gyarmatokon pedig 1830-ban szabadították fel a rabszolgákat. Annak ellenére, hogy Franciaországban a jakobinus többségú nemzetgyúlés 1794-ben megszavazta a rabszolgaság felszámolását, XIV. Lajos ordonnance-a, az ún. Fekete kódex 1685-től 1848-ig hatályban maradt. Így tehát a francia gyarmatokon csak 1848-ban szűnt meg a rabszolgaság mintegy 244 ezer fekete bőrű ember felszabadításával. Ezt követően az Amerikai Egyesült Államokban alkotmányos úton 1865-ben, Brazíliában 1871-ben, Kubában pedig csak 1880-ban került sor arra, hogy a volt rabszolgák dologból személlyé, jogalannyá válhassanak a pozitív jog szerint, mint ahogy addig is azok voltak a természetjog szerint. Afrika belsô részein azonban ezt követően is tevékenykedtek a rabszolgavadászok és rabszolga-kereskedők, akikkel maguk a törzsfők is kötöttek adásvételi üzleteket a más törzsből kikerülő hadifoglyokról és saját

\footnotetext{
12 OGRIS, Josepf Sonnenfels 110.
} 
törzsük egy részéről is. Ezeket az állapotokat 1890-ben Brüsszelben nemzetközi jogi egyezmény kívánta felszámolni, bár az emberkereskedelem rejtett formái továbbra is megmaradtak.

A jogegyenlőség biztosítása a modern büntetőjogban is alapvető célkitűzésként jelent meg: a büntethetőség feltételei, az eljáró bíróságok hatásköri szabályai, a büntetés mértéke vagy a büntetés-végrehajtás nem függhet a társadalmi állástól, nemtől vagy egyéb tényezôtől, mind emellett vannak olyan személycsoportok, amelyekre saját büntető anyagi, eljárási és végrehajtási szabályok vonatkoznak. Ilyenek a fiatalkorúak és a katonai bíróságok előtt elbírálandó személyek ügyei.

A természetjog és a felvilágosodás természetesen a büntetőjog-tudományt is megtermékenyítette. A jogegyenlőség biztosítása nélkül a modern büntetőjog többi elve értelmezhetetlen, azaz azok alapját képezi. Amikor Joseph von Sonnenfels, Mária Terézia udvari jogásza kifejtette, hogy a bűncselekményeket pontos törvényi tényállásban kell rögzíteni, ez már nem volt előzmény nélküli törekvés: az újkortól kezdve számos jogforrásban törekedtek a büntetendő magatartások pontos meghatározására, ahogy azt a német birodalmi Carolina (1532), XIV. Lajos büntető ordonnance-a (1670) vagy az alsó-ausztriai Ferdiandea (1650) is jelzi. Sonnenfels múvével egy időben (1764) jelent meg Cesare Beccaria itáliai büntetőjogász rövidke műve „A bűncselekményekről és a büntetésekről” címmel, melyben tételszerủen rögzítette azt, amit más szóhasználattal Sonnenfels is megfogalmazott. A nullum crimen sine lege elv érvényesülése kizárja azt, hogy a büntető igazságszolgáltatás a végrehajtó hatalom önkényes befolyása alá kerüljön. Beccaria célja a büntetőjog modernizálása, az önkény és a kegyetlenség elleni küzdelem volt, ahogyan Sonnenfels is - nem kis kockázatot vállalva - ez ellen szólalt fel Bécsben. Mária Terézia büntető törvénykönyve, a Constitutio Criminalis Theresiana (1768) alkalmazta a bűncselekmények törvényi meghatározásának követelményét, amely szerepelt a francia Emberi és Polgári Jogi Nyilatkozatban is, majd ezt követően általánossá vált a modern büntetőjogi kódexekben. Jellemző módon a polgári demokráciák értékeit kétségbe vonó államokban írták csak felül, mint többek között a francia jakobinus diktatúra idején, a náci jogrendben az ún. egészséges népi érzület kategóriájával, illetve a kommunista Szovjetunióban a dolgozó nép ellensége kitétellel. A nullum crimen sine lege elv értelmezéséhez hozzátartozik az is, hogy pontosan meghatározzuk, mikor keletkezett az a jogszabály, amely alapján a felelősségre vonás történik. Az Emberi és Polgári Jogi Nyilatkozat előírta, hogy mindenkit csak olyan törvény alapján lehet megbüntetni, amelyeket a bűncselekmény elkövetése előtt hoztak és hirdettek ki, és ezzel a kontinentális büntetőjogban a későbbiekben általánossá vált a visszaható hatály tilalma.

Éppen így a jogegyenlőség elve köszön vissza közvetett módon a büntetések (nemének és mértékének) törvényhez kötöttségében is (nulla poena sine lege), bár a forradalmi korszak abszolút határozott, szigorú büntetési rendszerét, amelynél a jogalkotó a bíró mérlegelési lehetôséget kizárta, a gyakorlati tapasztalatra hivatkozva két évtized múlva Napóleon büntető törvénykönyvében (Code Pénal, 1810) már felülírták. A modern büntetőjogi elvek közé sorolt analógia-tilalmat az angolszász jog területén a common law büntetôjog léte miatt nem találjuk meg, és szó szerint ugyan az Emberi és Polgári Jogi Nyilatkozat sem rögzítette. A büntetőjogra vonatkozó cikkelyei azonban tiltották az önkényes ítélkezést, valamint a nem törvény alapján történő ítélkezést, azaz az analógia alkalmazását és a szokásjog alapján történő eljárást is.

A modern büntetőjog elvei különösen rávilágítanak arra a fontos tényre, hogy ezek érvényesülése a gyakorlatban csak akkor lehetséges, ha az államépítési alapelvek biztosítják ehhez a feltételeket. E három utóbbi jogelv a törvények uralma államépítési elvben kapcsolódott egybe, és 
rendszerint együtt jelent meg a modern büntetőkódexekben. A modern büntetőjoghoz köthető a humanizmus elve is, melynek az anyagi jogi szabályokban, az eljárásban és a végrehajtásban is érvényesülnie kell. Sonnenfels és Beccaria egyaránt hangsúlyozta, hogy a büntetéseknek nem kegyetlennek, hanem az okozott sérelem nagyságával egyezőnek kell lennie, és a bűnüldözés hatékonysága nem a büntetőtörvények szigorából, hanem a felelősségre vonás elkerülhetetlenségéből fakad. Az önkényes jogalkalmazás pedig mindezt gátolja. Mindketten felléptek a tortúra alkalmazása és a halálbüntetés ellen is. Az angol Bill of Rights 1689-ben már rögzítette a kegyetlen és szokatlan büntetések tilalmát, majd erre a jogi tradícióra alapítva az amerikai Bill of Rights körében is helyt kapott ugyanez az elv 1791-ben. Az Emberi és Polgári Jogi Nyilatkozat erre a felvilágosult, természetjogi alapú felfogásra hivatkozva rögzítette, hogy „meg kell büntetni azokat, akik önkényes intézkedéseket szorgalmaznak, hoznak, végrehajtanak vagy végrehajtatnak", illetve „a törvény csak nyilvánvalóan szü̈kséges büntetéseket szabhat ki” (VII. és VIII. cikkely).

Mindezekkel szemben fontos felhívni a figyelmet arra a tényre, hogy a jogegyenlőség elve - az alkotmányjoghoz és a magánjoghoz hasonlóan - a büntetőjogban sem érvényesült feltétlenül a polgári modernizáció korában sem. Hogy csak a legfontosabb példákat nevesítsük, amíg a rabszolgaság intézménye létezett, amíg a zsidók polgári jogegyenlősítése késlekedett, amíg a női emancipáció részleges maradt, ezek hatása minden jogágban jelentkezett. Az egyes európai államok fejlődésében ezen kívül jelelentős időbeli és a modernizáció melletti elkötelezettség tekintetében politikai különbség is volt.

\subsection{A szabadságeszmény és a tolerancia követelménye}

A szabadságjogok történeti megjelenésének és kiteljesedésének különböző korszakokhoz köthető Európában. A középkorban a szabadságokat illetve mentességeket, azaz a kivételes jogállást privilégiumok formájában biztosítottak egy adott személynek vagy személycsoportnak a magánjog, a hủbéri jog, a büntetőjog vagy a feudális közjog területén. ${ }^{13}$ Ilyen előzmények után a jogegyenlőség elvére alapított, minden embert egyaránt megillető szabadságjogok a 16. század végétől, illetve a 17. században a polgári átalakulás és modernizáció úttörőinél, észak-németalföldi területen és Angliában természetjogi indokolással jelentek meg. Az elméletet többek között Donellus, Grotius és Althusius alkotta meg. A hugenotta Donellus a személyt megillető élethez, testi sérthetetlenséghez és közéleti megjelenéshez való jogról beszélt, Grotius az emberi jogok elidegeníthetetlenségét hangsúlyozta, Althusius pedig a jogegyenlőségről értekezett. ${ }^{14}$

A protestáns etikán alapuló természetjogot az angol szigetország majdhogynem készen vette át tôlük a puritán forradalom során. Az eredményt ebben a korszakban a rendi Magna Carta Libertatumra hivatkozva a Petition of Rights (1628), a Habeas Corpus Act (1679) és a Bill of Rights (1689) rögzítette. Ez utóbbi törvény - a tradíciókból táplálkozó angol modernizáció részeként - az angol alattvalók jogait valóságos, ősi és kétségbe vonhatatlan jogként értelmezte. Annak ellenére, hogy ezzel bizonyos mértékben a szabadságjogok pozitivizált joggá váltak, összességében csak az

\footnotetext{
${ }^{13}$ KELLER, Freiheitsgarantien 7.

${ }^{14}$ HaLmai, Az emberi jogok igazolása 20-37.
} 
alapjogok előjogaina tekinthetők, mivel a királyi hatolom korlátjaiként, rendi jelleggel fogalmazták meg őket. ${ }^{15}$

A szabadságjogok átfogó pozitivizálása az amerikai, illetve francia jogfejlődésben valósult meg. Ennek alapvető dokumentumai az USA-ban a Függetlenségi Nyilatkozat (1776) ${ }^{16}$ valamint a szövetségi alkotmány első tíz kiegészítését tartalmazó Bill of Rights (1791), Franciaországban az Emberi és Polgári Jogi Nyilatkozat (1789) voltak. A szabadságjogokat az amerikaiak a Teremtótól származó, veleszületett és elidegeníthetetlen jogokként, a franciák természetes, elidegeníthetetlen és megszentelt jogokként értelmezték. Ezek a klasszikus szabadságjogokat tartalmazó dokumentumok a politikai társulások célját abban látták, hogy a polgárok számára a jogaikat biztosítsák. Könyvtárnyi irodalom foglalkozik azzal a kérdéssel, hogy az amerikai vagy a francia dokumentumok tekinthetők nagyobb hatásúnak. Minden részletezés nélkül ehelyütt csak annyit jegyeznénk meg, hogy az amerikai Bill of Rights valódi jogvédelmet biztosított, hiszen alkotmányos jog sérelme esetén az állampolgár bírósághoz fordulhatott, míg az Emberi és Polgári Jogi Nyilatkozat csupán egy államcélokat tartalmazó deklaráció volt. Eszmetörténeti jelentősége azonban mindkettőnek hatalmas nem csak Európában, hanem az Európán kívüli polgári modernizáció tekintetében is.

Természetesen nem hiba nélküli egyik dokumentum sem. A politikai és társadalmi környezet hatására jó példa, hogy az újszülött Amerikai Egyesült Államokban a philadelphiai alkotmányozó konvenció az alkotmány törzsszövegéből lényegét tekintve kihagyta az emberi jogokat. ${ }^{17}$ Úgylátták jónak, hogy a szabadságok alkotmányi rögzítése nyugodtabb időkre maradjon annak ellenére is, hogy a többségi zsarnokság elkerülésének fontos eszközét látták bennük, hiszen a többségi akarattal szemben a kisebbség ezekkel az egyéni és kollektív szabadságjogokkal élve fejtheti ki kellő módon véleményét. 1789 nyarán a föderalisták az alkotmányos intézményrendszer stabilizációja érdekében a korabeli emberi jogi felfogásnak megfelelően terjesztették elő a klasszikus szabadságjogokat tartalmazó katalógusukat. A Bill of Rights, amely a ratifikációt követően 1791. december 15-én lépett hatályba, csupán egy rövid felsorolás volt, melynek értelmezése a szövetségi Legfelső Bíróságra várt. Ez a folyamat ma sem lezárt. Alakulásában jelentős szerepet töltenek be a „tisðtesség fejlódő követelményel” („,the evolving standards of decency”), azaz a közösségi értékszemlélet változása.

Az eszmény és a valóság közötti szakadékot jelzi, hogy a Bill of Rights rendelkezései a szövetségi törvényhozó hatalom, a Kongresszus irányába jelentettek kötelezettséget, azaz a X. cikkely értelmében a tagállamok igen szigorú törvényeket hoztak a szabadságjogok területén ott, ahol a szövetségi hatáskör hiánya ezt lehetôvé tette. Ezért 1868-ban újabb alkotmánykiegészítésben (XIV. cikkely 1. \) döntöttek arról, hogy egyetlen állam sem hozhat vagy alkalmazhat olyan törvényt, amely korlátozza az Egyesült Államok polgárait megillető jogokat. Így a tagállamok és az unió közötti kapcsolat egyes vonatkozásainak rendezése kapcsán a Bill of Rightsban deklarált jogok

\footnotetext{
${ }^{15}$ Lásd bővebben KAJTÁR - HERGER, Egyetemes állam- és jogtörténet 164-172.

16 http://www.verfassungen.net/us/index.htm

${ }^{17}$ Pár apró szabályt rögzítettek csak. Ilyen az elnök szabadsága arra, hogy eldöntse, szekuláris vagy a szakrális esküt tesz-e hivatalba lépésekor (II. cikkely 1. §), az a szabály, hogy - az európai, illetve gyarmati tradícióval szemben - az Egyesült Államok joghatósága alá tartozó hivatali tisztség vagy megbízás betöltésével kapcsolatban nem lehet vallási hovatartozást megkövetelni (VI. cikkely), vagy az angol jogi tradícióval magyarázható Habeas Corpushoz való jog és a bill of attainder tilalma (I. cikkely 9.\$).
} 
az utóbbi cikkely védelme alá kerültek. Ennek értelmében az alkotmányos jogok - nagyjából száz év alatt - a tagállami jogokban is érvényesüléshez jutottak. Minden esetre a négy ízben (1868, 1880, 1886, 1892) is angol miniszterelnökké választott liberális William Gladstone az amerikai alkotmányt az emberi elme és szándék által valaha alkotott legcsodálatosabb múnek nevezte. Ha ez a megállapítás némiképp túlzónak is tünik, kifejezi, hogy az amerikai modell demokrácia iránti elkötelezettségével és intézményeivel közvetve vagy közvetlenül befolyásolta számos európai és Európán kívüli állam polgári modernizációs törekvéseit is.

Az Emberi és Polgári Jogi Nyilatkozatba foglalt jogokat a francia alkotmányfejlődés egyes, néha igen mozgalmas szakaszaiban a politikai környezetnek megfelelően értelmezték és használták fel a politikusok érvelésük során. Így az 1791-es alkotmány teljes egészében átvette a deklaráció szövegét, annak elejére került beillesztésre. Az 1793-as ún. jakobinus alkotmány pedig (amely egyébként nem lépett hatályba) az egyenlőség irányában fejlesztette tovább. Az 1795-ös alapdokumentum visszatért az 1789-es eredeti forrásokhoz, azonban már a francia polgár kötelességeiről is megemlékezett. A Napóleon nevéhez fűződő politikai rendszerek (a konzulátus, majd a császárság) érthető módon nem állították politikai és közjogi nyilatkozataik kirakatába a deklarációt és nem is azonosultak elveivel. A 19. század közepén a jogok alkotmányos rögzítése után az aktuális történelmi tapasztalatoknak megfelelően beillesztették azt az óvatos záradékot, hogy az adott jogokat a törvény korlátozhatja, a bonapartizmus több kiadást megért politikai rendszereinek idején pedig ilyenfajta katalógust az alkotmányos dokumentumok között hiába is keresünk. A 19. század alkotmányaiban szerepe halványabbá vált, míg a második császárság idejében Bonaparte Lajos politikai boszorkánykonyhájában már csak formálisan tisztelt, de nem alkalmazott jogtörténeti emlékké változott. Az 1880-as évek liberális refomhulláma során a szabadságjogokat újra a francia forradalmi hagyományoknak és felvilágosult eszméknek megfelelően szabályozták illetve pontosították, majd a századforduló éveiben lezajlott az egyház és az állam következetes szétválasztása is, bár ebben a köztársasági hagyományok ateista és antiklerikális elemekkel párosultak. A jogok és szabadságok katalógusát magában foglaló deklaráció a későbbiek folyamán szinte standard közjogi múfajjá vált. Ennek keretében a német nép alapjogairól szóló (1849-es) nyilatkozat mellett a 20. század közepén hivatkozhatunk az Emberi Jogok Amerikai Nyilatkozatára (1948) vagy az Emberi Jogok Egyetemes Nyilatkozatára, amely 1948-ban az ENSZ égisze alatt jött létre, majd 1966-ban kiegészült a Polgári és Politikai Jogok Nemzetközi Egyezségokmányával valamint a Gazdasági, Szociális és Kulturális Jogok Nemzetköri Egyezségokmányával.18

\section{Következtetések}

Egységes értékfelfogás Európában soha sem volt és bizonyára soha nem is lesz. Míg a korai polgári forradalmak időszakában az újra felfedezett természetjog és a bibliai gyökerű, protestáns etikán alapuló elvek domináltak az alkotmányos dokumentumokban, a felvilágosult észjog elvei és a tradicionális vallással szembeni merev ellenállás a nagy francia forradalom korától meghatározóvá vált. A 18-19. század fordulójától a szekuláris gondolkodásmód előretörése mellett is maradt azonban némi szerepe a zsidó-keresztény jogi kultúrára visszavezethető értékeknek, amelyek az

\footnotetext{
${ }^{18}$ Kajtár - Herger, Egyetemes állam- és jogtörténet 219. és 231.
} 
egyes európai államokban korszakonként eltérő intenzitással álltak és állnak a politikai és jogalkotói döntések mögött azok indokolásaként.

\section{Felhasznált irodalom}

ALEXY, Robert: Theorie der Grundrechte. Frankfurt am Main 1986

ADAMS, John: Értekezés a kánonjogról és a feudális jogról. In: LÉVAI Csaba (válogatta, fordította, szerkesztette és a jegyzeteket készítette): Új rend egy új világban. Dokumentumok az amerikai politikai gondolkodás korai történetéhez. Debrecen 1997, 3-24.

HALMAI Gábor: Az emberi jogok igazolása. In: TALLÁr Ferenc (szerk.): Az emberi jogok és az európai tradíció. Budapest 2002, 20-37.

HERGER Csabáné - KAJTÁR István (szerk.): Jogtörténészportrék I. Werner Ogris. Budapest-Pécs 2007

HERGER Csabáné - KAJTÁR István: Egyetemes állam- és jogtörténet. Budapest - Pécs 2015

HINZE, Otto, Wesen und Wandlung des modernen Staats. In: Staat und Verfassung. Gesammelte Abhandlungen zu allgemeinen Verfassungsgeschichte. Göttingen 1962, 470-497.

HUBER, Ernst Rudolf: Bedeutungswandel der Grundrechte. Archiv des öffentlichen Rechts 1933/62 1-98.

KELLER, Robert von: Freiheitsgarantien von Person und Eigentum im Mitelalter. Heidelberg 1933

MILL, John Stuart: A szabadságról. Budapest 1980

NiETLISPACH, Fritz: Grundlagen der Freiheitsrechte. Zürich 1977

PÉTER László: Volt-e magyar társadalom a XIX. században? Valóság 1989/5. sz. 5-8. 
SCHWEITZER Gábor

tudományos főmunkatárs MTA TK JTI

habilitált egyetemi docens NKE ÁKK
DOI: 10.15170/DIKE.2017.01.01.04

\section{„Újabb időkben sok magyar utazik a mívelt külföldön” Politikai-társadalmi útirajzok a 19. század első feléből}

\section{„Recently Many Hungarians Are Traveling to the Civilized Abroad” Political and Social Travelogues from the First Half of the 19th Century}

This paper examines how Hungarian travelers presented and characterized the legal system, constitutional life, political, educational and social institutions of Western European countries and the United States in their travel diaries and travelogues in the first half of the 19th century. The authors of these works such as Bertalan Szemere, Sándor Farkas Bölöni, Miklós Wesselényi and others, were among the supporters of the constitutional, political and social reforms in Hungary during the reform era. The basic goal and the prior aim of these travel diaries was to make comparisons between the Hungarian constitutional, political and social institutions with the similar institutions of western states and societies.

Keywords: travel diary, travelogue, 19th century, reform era, constitution, constitutional institutions, political life, educational institutions, West Europe, United States

1. „Szemere Bertalannak a sajtót e napokban elhagyott utazását már olvastam. Meleg philantropi szellemtöl van áthatva, a leggondosb figyelemmel jegyzé föl mind åt, mit külföldrül honunkba átültetni üdvös volna. Vannak benne csekély fontosságú dolgok is, és sok mi csak a' sžerzó egyéniségére tartozónak látszik, de a' bájos elöadás ezeket is igen érdekesség teszi, s' menti az is, hogy napló alakban van a' mü irva, miben a' gondolatoknak, s' érzelmeknek is helye van."1 - ezeket a sorokat Szücs Miklós, egy alig húsz esztendős fiatalember jegyezte a naplójába 1840. szeptember 6-án. A politikai, társadalmi és kulturális élet kiemelkedő eseményeit gondosan megörökítő jogvégzett naplóíró figyelmét azonban nemcsak Szemere Bertalan nyugateurópai útleírása keltette fel, hiszen a Bölöni Farkas Sándor észak-amerikai útinaplóját is többször átlapozta.

Bölöni Farkas Sándor 1834-ben Kolozsvárott megjelenő Utazás Észak-Amerikában című könyve, valamint Sžemere Bertalan „Utazás külföldön” címû 1840-ben Budapesten (!) kiadott munkája a legismertebb reformkori politikai-társadalmi útirajzok, útleírások, útilevelek és útinaplók közé tartozik. A korszak sajtója és könyvkiadása fontosnak is tartotta ezeknek a múveknek a közzétételét. Aki azonban nem kívánt vesződni a cenzúrával, külföldön próbálkozott nyomdát,

\footnotetext{
${ }^{1}$ SZÜCS, Napló 90. 1840. szeptember 6-i bejegyzés.
} 
illetve kiadót keresni kötete számára. Ezt a megoldást választotta Irinyi József, aki 1846-ban Halléban tette közzé „Német-francia és angolországi úti jegyzetek” című könyvét.

A nyugati világot bemutató útirajzok szerzőinek többsége - miként Szalay László, Szemere Bertalan, Pulsæky Ferenc, Tóth Lörinc, Gorove István, Irinyi József, Erdélyi János - a politikai és társadalmi reformokat szorgalmazó, de legalábbis támogató politikusok, tudósok, szellemi és közéleti személyiségek közül került ki. ${ }^{2}$ Az útleírások közzétételét a hétköznapi látnivalók bemutatása mellett az is motiválhatta, hogy a nyugat-európai alkotmányos, jogi, politikai és társadalmi intézmények megismertetésével a hazai politikai és társadalmi reformok számára is felvillantsanak megoldási lehetőségeket. Az útirajzok szerzői alkalmanként össze is hasonlították a hazai állapotokat a külföldön látott és tapasztalt megoldásokkal. Az útleírások, útilevelek és útinaplók ebben a tekintetben a hazai jogi komparasztika első hajtásait is jelentették, miközben magától értetődően nem tudományos célzattal és módszerrel készült munkákról van szó. ${ }^{3} \mathrm{Az}$ összehasonlítás mellett óhatatlanul felmerül a recepció, illetve az adaptáció kérdése is. Mennyiben szükséges, illetve lehetséges a nyugat-európai államokban látott intézmények átvétele, illetve alkalmazása a hazai reformok előmozdítása érdekében? Erre a kérdésre nem adható egyféle válasz. Az útleírások szerzői közül Irinyi József óva intett a mechanikus átvételtől, hiszen miközben a nyugati államok kétségkívül megérdemlik figyelmünket, a külföldi példa az ész világító fénye mellett „csak másodrendü dolog legyen a bizonyító okok sorában." S Szemere Bertalan viszont az átvétel szükségessége mellett érvelt: „Mint küsqködünk mi azzal, ami itten rég megfejteték, mint tapogatjuk félénken, mi itten rég világos. (...) Utazás sok idöt s eröt megkimél, sok kürdéstöl s kételytül megment, és nekünk, kike a pályán az. utósók közt vagyunk, nem találni, csak eltanulni, nem keresni, csak válas:tani, nem teremteni, csak másolni kell." 5 Szalay László sem látott különösebb kivetnivalót abban, ha Magyarország „utánozza” az angol és francia „alkotmányos státusélet” megoldásait, amennyiben együtt kíván múködni az „európai népcsaláddal'. ${ }^{6}$

Nem minden útirajz íródott kifejezetten politikai-társadalmi célzattal. Az 1830-as évek közepén Svájcban és Itáliában utazgató Wesselényi Polixéna figyelmét mindenekelôtt a mûvészeti és természeti látnivalók, valamint a társas élet terei kötötték le, bár találó politikai és társadalmi jellegű észrevételeket is tett. Genfi tartózkodása csalódást keltettek az útleírás szerzője számára a politikaifilozófiai eszmék és a társadalmi valóság közt tapasztalt ellentmondások. „Odahagyni a szabadság, polgári egyenlöség respublikának nevez̧ett földpontocskáját - fájt. Mily hatalma van reánk nézve egy gyerekekorunkban tisztelni megtanult névnek! Ámbár polgári egyenlöséget és szabad nemzet magas erényeit - amint tapasz̧talás nélküli képzeletim lehetségesnek. festették vala - nem találtam. Respublikai képzetimmel éppen ellenkezó" volt ezen rideg kasztokra osztott emberi hangyaboly; mert Geneva polgárai oly szoros, áthághatatlan, különrekesztó kasz̨tokra vannak elosżtva, mint hajdanában Egyiptom lakóji. (...) Respublikeai egyenlöséggel álmadozók! Ne

\footnotetext{
${ }^{2} \mathrm{~A}$ reformkori nyugat-európai utazások politikai és társadalmi jelentőségéhez lásd: FENYŐ, A polgárosodás eszmevilága 603-612., továbbá KAJTÁR, A 19. századi modern magyar állam- és jogrendszer 41., valamint KECSKEMÉTI, Magyar liberalizmus 117-118.

3 A hazai összehasonlító jogtudomány kialakulásához újabban lásd HALÁsz, Wenzel Gusztáv és a magyar jogi komparatisztika kezdetei 152-162.

${ }^{4}$ IRINYI, Német-francia- és angolországi úti jegyzetek 11.

${ }^{5}$ SZEMERE, Utazás külföldön 9.

${ }^{6}$ SZALAY, Eredetiség 's utánzás 207.
} 
válasszátok. Genevát ideáltok típusának. Ennek emberi egyenlöséget birdetö filozófusa képzelt respublikeajához. sclavok tartoztak??

A természettudós Nagy Károly az 1830-as évek elején jutott el Amerikai Egyesült Államokba. A hazai sajtóban megjelenő útilevelei politikai-társadalmi kérdéseket alig-alig érintettek. A kivételek egyikeként viszont mély együttérzéssel számolt be az őshonos indián lakossággal szembeni embertelen bánásmódról. „A szegény honföldiekröl - az. Indusokeól - kik. e 'státusban még itt's amott egy két nemzetségben nyomorún léteznek, majd személyesen fogok neked bolmit elbeszélni. Szívem szorong 's vérzik keblemben, ba 'boldogtalan emberfaj eszembe jut; borzadok, ha meggondolom, mint nyomják ki a 'fejér emberek e' faj maradékait lassanként az, anyaföldröl (...). Atok a' civilisatióra, ha ezen áron nyeri terjedését?’s

Nem mindenki publikálta a külföldi utazási élményeket rögzítő naplókat. A hosszú időt külföldön töltő Széchenyi István, vagy az éppenséggel Széchenyi Istvánnal Nyugat-Európában és Angliában utazgató Wesselényi Mikelós nem jelentették meg az utazások során készített naplókat, feljegyzéseket. Múveikben természetesen felhasználták a külföldi tartózkodás során szerzett ismereteket és tapasztalatokat. Eötvös József ugyan azt tervezte, hogy nyugat-európai utazásairól szóló feljegyzéseit közzéteszi, de végül a svájci utazásokról készült kéziratot nem adta ki, franciaországi tapasztalatait pedig a „Karthauzi” címú regénybe építette be. Saalay László az Athenaeum hasábjain jelentetett meg néhány közleményt az útinaplókból, ám tudományos műveiben, miként „A büntető eljárásról, különös tekintettel az esküttszékekre” címen közzétett munkájában bőségesen kamatoztatta a nyugat-európai tanulmányúton szerzett ismereteket.

A politikai útirajzok, illetve útinaplók szerzői közül többen rendkívül tudatosan készültek a nagy utazásra. Wesselényi Miklós - nem sokkal nyugat-európai utazásai előtt - a következő sorokat jegyezte fel naplójába: „Gyermekekoromtól fogva már élt bennem a vágy utazások által magamat javitani, erösbiteni, idegen, müvelt népek ismeretével önmagamat erkölcsileg és ész̧belileg tovább fejlesżteni s a természet változatos szépségeit, a dolgozó emberek merész alkotásait szemlélni és élvezni." A felkészülés jegyében Wesselényi Miklós még angol nyelvleckéket is vett. Szalay László az Athenaeum címú folyóiratban megjelenő úti naplójában hivatkozott arra, hogy ifjúkori legforróbb vágyai közé tartozott „egy nap láthatni a külföldet."10 Bölöni Farkas Sándor pedig a következő sorokat írta az úti készülődés idején Gedő József nevü barátjának: „Össz̨el szándékszom - úgymond - innen mintegy másfél vagy két esztendôkre elmenni. Az ég meghallgatta kérésem, s talán elérem ąt, mi életemnek, egyik. fövebb obajtása volt, vagyonomnak egy része feláldozásába kerül ugyan, de ennél szebb kivánságomra soba sem költök. Én most mint egy deák, szüntelen tanulok: geographiai, statistikai és constitutiói ismereteket kell elóre szereznem."11

Széchenyi István és Wesselényi Miklós sokáig tervezték egy közös amerikai út lehetőségét. Naplóikban erről többször tettek említést. Lelkesedésüket leginkább az válthatta ki, hogy az Amerikai Egyesült Államokat, miként egyik feljegyzésében Wesselényi Miklós fogalmazott, a

\footnotetext{
7 WESSELÉNYI , Olaszhoni és schweizi utazás. http://mek.oszk.hu/01000/01017/01017.htm

${ }^{8}$ NAGY, Utazási töredékek Éjszak-Amerikából 410. Nagy Károly múködéshez lásd BARTHA, Egy reformkori tudós 27-32 valamint ZÁvODSZKY, Az Amerika-motívum 122 ff.

${ }^{9}$ SZÉCHENYI - WESSELÉNYI, Feleselő naplók 73, 1821. október 29-bejegyzés.

${ }^{10}$ SZALAY, Úti naplómból 370.

${ }^{11}$ Bölöni Farkas Sándor levelét Gedó Józsefhez. (1829. március 30.) idézi: JAKAB, Bölöni Farkas Sándor és kora 291.
} 
szabadság azon dicső hazájának tekintették, amelyet még nem fertőzött meg a szolgaság levegője. ${ }^{12}$ Az amerikai út azonban elmaradt, hiszen az angol partoknál végül nem jutottak tovább.

2. De mi kelthette fel Szǘs Miklós figyelmét a politikai-társadalmi útirajzok olvasásakor? Szemere Bertalan a következő témákat ajánlotta olvasói figyelmébe kötete bevezetőjében: „... Németföldön különösen a népiskolákat, Franciaországban a nyilvános életet, Nagy-Britanniában a fogházakat s népjellemet (...) választám az̧on fénypontul, mi körül egyéb tárgyak csoportozatai összegyülnek."13 Bölöni Farkas Sándor pedig elsősorban amiatt ragadott tollat, mert „a a amerikai polgári és társasági életben sik oly pontot találtam tökéletre kiffejtve, és sok oly tudnivalót, mik még nálunk, legalább magyarul, ismeretlenek."14

Szemere Bertalan tehát Szászország és Poroszország kapcsán mindenekelőtt a népoktatási rendszer működését emelte ki: „Míg Nyugat népei papiralkotványokért dulakodnak, a csendes Németország polgári rendet nevel, mely mind a francia, mind az angol középosztálynál müveltebb lévén, erösb, tömöttebb s állandóbb leend. E nagy munkán dolgozik minden, hatalmával a kormány, részuétével a nép, szellemi erejével a tudós." 15 A szász és porosz népoktatási rendszer bemutatását követóen jó szívvel javasolta a hazai törvényhozás számára, hogy ezen minták nyomán szabályozza, illetve szervezze meg a népoktatási rendszert. Miközben Szemere Bertalan Franciaországot a szabadság, Olaszországot a múvészetek, Angliát az emberész hazájának tartotta, addig Poroszországot a népnevelés hazájaként mindhárom előbb említett állam fölé helyezte. ${ }^{16}$

Pulsæky Ferenc hasonlóan vélekedett Poroszországról az 1836-os úti jegyzetekben: Poroszország ugyan nem rendelkezik alkotmánnyal, „de van két erösebb institutiója, melly a’ népbe mélyen behat, 's a' jólétet biztositja": a népiskola, amely a „legalsóbb rendekig" terjeszti a tudományt, valamint a három évig tartó Landwehr, amely a nemzet számára férfiasabb és nemesebb tartást biztosított. ${ }^{17}$

Irinyi József viszont úgy látta, hogy a porosz népnevelés mögül hiányzik az alkotmányos szabadság, a politikai élet, amelyek nélkül mesebeszéd a nép múveltségével előállni. A nép műveltségének legjobb eszközének az alkotmányos élet megteremtését tekintette. ${ }^{18}$ Irinyinek amúgy az volt a véleménye, hogy az államjogi szempontból felszabdalt, központ - ahogy nevezte: alap nélküli német térségben mûködő államok nem élnek valóságos államéletet: „Németország valósággal nem is egyéb, mint üvegházi növény." 19

Wesselényi Miklós érdeklődését mindazonáltal felkeltették a bajor és a württembergi alkotmányos monarchia alapintézményei. Müncheni tartózkodása idején a naplóíró nagyon készült arra, hogy részt vegyen a törvényhozó testület egyik ülésén, de erre a látogatásra végül időhiány

\footnotetext{
12 SZÉCHENYI - WESSELÉNYI, Feleselő naplók 75. 1821. november 2-i bejegyzés: „Széchenyivel reggel 91/2 órakor Czenkre kiindultunk. Mely különbség a minapi bejövetelünk s mostani kimenetelünk közt. Akkor mind csak utunkról, Amerikáról, elindulásunkról beszéltünk, lelkesitve lehellet reánk a szabadság azon dicső hazájának a szolgaság által még meg nem fertőztetett levegője szép képzetinkbe. Most mindazokról egy szót sem. Mindazon kitételek helyett, melyeket Széchenyi egy órában tizszer is mondott: „Du wirst schon in England sehen” "Auf unserer Reise nach Amerika” most egy-egy fagyos „Solltest Du jemals nach England kommen” „Sollten wir je zusammen eine Reise machen” vet ki számomra."

13 SZEMERE, Utazás külföldön 9.

14 BÖLÖNI, Napnyugati utazás 281.

15 SZEMERE, Utazás külföldön 27. 1836. október 19-i bejegyzés.

16 SZEMERE, Utazás külföldön 67. 1836. november 2-i bejegyzés.

17 PULSZKY, Úti vázlatok 46.

${ }^{18}$ IRINYI, Német-francia- és angolországi úti jegyzetek 33 ff.

${ }^{19}$ IRINYI, Német-francia- és angolországi úti jegyzetek 26.
} 
miatt nem kerülhetett sor. „A rendek épen össze vannak gyülve. Nagyon sajnálom, hogy egy ülést sem láthatok, mert ma még nem lészen és holnap annyira kell sietnünk, hogy nem maradhatunk. 2 órával tovább itt, e nekünk, magyaroknak oly érdekes dolgot végig hallgatni. Hogy ezen gÿ̈lekezet céljánake és méltóságának megfelel-e vagy nem, bogy igaz, vagy igaztalan úton jár-e - egyformán érdekes és tanulságos lenne tudni. Annál is inkább kivántam volna az. egybegyült rendeket közelebbröl látni és hallani, mert itt egészẹn különös módon tárgyalják mükëdésüket: nevetnek rajtuk. A bibának vagy a megitélö tömegben, vagy a rendek gyülekezetében kell lennie, de mindkét esetben óriási és a jövöre nézve nagyon káros. Úgy hallom, hogy igen szabadon beszélnek, közbe-kǫ̈̈be súlyosan támadják a felelös minisztereket. Különben eddig még egy kiváló szónokuk sincs, de hogy is volna ez - sör és kifött gombócok mellett - lehetséges?" - fogalmazott az útinapló számára. ${ }^{20}$ Württemberg ugyanakkor a bécsi kongresszus óta, Wesselényi Miklós értékelése szerint, a kor szelleméhez képest igen liberális alkotmánnyal rendelkezett. „A miniszterium felelös. A tanácskozások megkezdésekor maga a király proponálja az újonnan behozandó törvényeket s mig e terveket le nem tárgyalták, a rendek nem tehetnek önálló propositiokat. Ily módon a király csak elegendö munkával kell ellássa a rendeket, és bižtos lehet, hogy oppositiora nem kerülhet sor. A törvényeket a király szentesiti; ha a király megtagadja valamely törvény szentesitését, három év mulva üjra tárgyaltatik e törvény. A rendek minden harmadik évben gyülnek össze. Szónoki tehetségek itt ép oly kevéssé vannak, mint Bajorországba, de a nyelv (sváb tájszólás) igazán nem szónoklásra való s egy ily sváb Demosthenes bizonyára mulatságos lehet."21

A bajor királyág alkotmányos intézményeirôl viszont Tóth Lörincnek igen kritikus véleménye volt. Az alkotmány elismerte ugyan a szabadságjogokat, de garanciákkal már nem bástyázta körül azokat. „Bajororşág alkotmányos orşág, alkotmánya 1818-ki csinálmány. Hasonlit a' többi német alkotmányokhoz, mellyekbe sok ép elv van lefektetve, életerö nélkül, mert hiányzanak azon garantiák, mellyek biz̧⿻sítják az életet. (...) A' bajor alkotmányban is, mint a' többi német alkotmányok' nagyobb részében ki van mondva a' lelkisméret', a' vélemény', a' szólás' szabadsága, de olly törvényes megszoritásokekal a' lehetö visszaélések. ellen, mellyek határozatlan magyarázatúak 's a' magyarázat' kulcsa a' hatalom' kezében lévén, az önkénynek, tárt kaput nyitnak, 's a' szerencsétlen megelózón rendsžer' szabadságellenes szabályai szerint úgy korlátozva, 's akkint készîtve el, hogy a' fényes theoriákból alig képes a' kijätszott élet valamit megmarkolni. Ki van mondva a' státus polgárok' egyenlösége fegyver- adó- 's egyébb terherviselésben, hivatalképességben, s' a' törvény elött, de különös rendkivüli esetekben kivételek 's kedvezmények vannak fentartva, mellyek a' szabályt magát azonnal megsemmisitik, mihelyt a' hatalomnak ügy teszik..'22 Pulszky Ferencet a szászországi alkotmányos monarchia se hozta lázba: „Szász-országban, a’ reformatio' honában, most egy szülkmellü aljas szellem uralkodik a' népnél, melly constitutionalismus által palástoltatik, de mindekekoráig bizonyos, hogy két kamararendszerö̈k csak annyiban volt hasznos, mennyiben a' nép látja, milly nehéz. országot közumegelégedésre kormányozni." ${ }_{23} \mathrm{Az}$ úti feljegyzésekben viszont Bölöni Farkas Sándor elismeréssel írt a bajor alkotmányos monarchiáról, de némi túlzással azt állította, hogy a bajor uralkodó „nemes magamegtagadással' mondott le az abszolút uralomról, és az arisztokrácia, valamint a papság által elnyomott nép számára szabad konstitúciót adott. ${ }^{24}$

\footnotetext{
${ }^{20}$ SZÉCHENYI - WESSELÉNYI, Feleselő naplók 128-129. 1822. március 5-i bejegyzés.

${ }^{21}$ SZÉCHENYI - WESSELÉNYI, Feleselő naplók 131. 1822. március 7-i bejegyzés.

22 TótH, Úti tárcza 82-83.

23 PULSZKY, Úti vázlatok 45.

${ }^{24}$ BÖLÖNI, Napnyugati utazás 103. 1830. december 5-i bejegyzés.
} 
De hadd folytassák útjukat Frankhon felé! Szemere Bertalan érdeklődését Franciaországban leginkább a „nyilvános élet” színterei keltették fel. Részletesen ismertette a választási rendszer intézményeit, valamint a kétkamarás törvényhozó testület működését. A komparatisztika jegyében

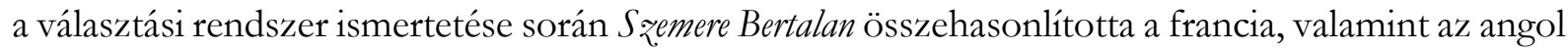
„követkamara” és a magyar alsótábla társadalmi, foglalkozási összetételét. „Nálunk a követkart teszi: táblabiró, ügyvéd, tisztviseló. De mi ez más, mint három névvel nevezett egy személy? Ehhez, adok két-három tudóst. Már most hol van a kereskedési-s iparérdeknek értelmes képviselöje? A városi követek sz̨inte csak tisz̨viselök, s ha másképpen volna is, hiszen nincs szavok. (...) Külföldön ez. mind másképpen áll. A követek közt van ügyvéd, biró, birtokos, kereskedó, tudós, bivatalnok a kormány minden ágaibul, katona, gyárnok, és mi legtöbb exminiszter. Hogy jobban meggyözödjél, barátom, vizsgáld meg, a magyar, francia, angol követház mi elemekböl van szerkesz̨tve. A francia ez évi kamarában van: miniszter 5, miniszteri bivatalban dolgozó 8, tábornagy 1, vezérrangú tisz̨t 19, ęredesen aluli 20, alhajóvezér 1, a béke, törvényszéke, királyi s cassatio-tábla birái közül 74, miniszterkövet idegen udvaroknál 2, statustanácsnok s ezen tanácshoz tartozó 18, egyetemektöl 3, királyi mérnök 4, finánci tárnok 1, hadi tárnok 8, stb., sqóval királyi szolgálatbeli 164, ę̧en kivül: ügyész 46, orvos 8, kereskedó, pénquáltó és gyámok. 39, vashámorok birtokosa 8, jegyző 4, és föld- báz töpénz̧birtokos 178, sqóval nem királyi bivatalbeli 283, összesen $=447$. Az angol ez idei albázban van: lord 59, hajóvezér 3, vezér 14, squárazi s tengeri alsóbb tiszt earedestöl a hadnagyig 142, lord-helynök 7, alhelynök 42, lovag, baronet s ily rangú 153, ügyész. 61, pénquáltó 40, kelet-indiai birtokos 33, nyugoti 17, kormánybivatalnok. 52, sinecurista 114. A magyar követtáblán 1832-ben volt: alispán 42, táblabiró 36, alsóbb bivatalbeli 27, a városok részéról részint biró, részint tanácsbeli 74, sqóval a követtábla állt 179 törvénytudóbul és 44 teológbul. Könnyü átlátni, barátom, hogy a föladatokat jobban az a törvényhozás fejtheti meg, mely magában több ágbeli férfiakat egyesit." 25 A következtetés egyértelmû: az a törvényhozó testület képes az érdemibb munkavégzésre, amelynek tagjai szélesebb spektrumban reprezentálják a foglalkozási ágakat. Anglia kapcsán az útleírás szerzője az alsóházi képviselő és az alsótáblai követ státusza közti különbségre is rámutatott. „Itt a követ az egész ország képviselóje, nem a válasz̨tott megyéé vagy városé, mi okbul itt utasitások nincsenek, mert az ország képviselöjének. azokat csak nemzet adhatna (mi törvény lenne), nem pedig egy tartomány. Azok tehát, kik egyiránt az egész nép képviselöi, kikeet utasitás nem köt s mégis egyértenek, inkább és természetesen fölvehetik a barát nevezetet, mert itt a politikai hit és sqó, éppúgy, mint a squv érzése, pusz̧tán a követé, mint egyedés nem mint utasitott képviselóé. (...) A 658 tag tehát az alház̧̧an inkább ugyanannyi egyed, semmint követ; nálunk inkább ugyanannyi këvet, semmint egyed. Azok tanácskoznak s végeznek, meggyözódésökön kivül senkire nem ügyelve, mint a nemzet föltétlen megbizottai, küldvék az ország külön részébül; követeink pedig jobb kezeiket az utasitásra, balaikat keblökre teszik, mindkettöre kell hallgatniok." 26 A francia illetve angol törvényhozás megválasztására, összetételére és múködésére vonatkozó tudósítások eléggé egyértelműen utalnak arra, hogy az útinapló szerzője szerint felettébb időszerű lenne a hazai törvényhozás szervezeti és múködési reformja.

Az igazságszolgáltatási rendszer bemutatása során Szemere Bertalan részletesen szólt az esküdtszékről, már csak amiatt is, mert Magyarországon még a közügyeket vezérlők között sem

\footnotetext{
${ }^{25}$ SZEMERE, Utazás külföldön 186. 1837. február 14-i bejegyzés.

${ }^{26}$ SZEMERE, Utazás külföldön 268-269. 1837. június 7-i bejegyzés.
} 
sokan ismerték akkoriban ezt az intézményt. ${ }^{27}$ Az esküdtszék jelentőségét legfőképp abban látta, hogy ez az intézmény teremtette meg az ártatlanságnak a legerősebb és legszilárdabb biztosítékát. A nyilvános élet színterei közül természetesen a sajtó - a szabad sajtó - múködésének bemutatása sem hiányozhatott. A sajtószabadság biztosítása Szemere Bertalan szerint a mindenkori kormányzatnak is érdekében áll, hiszen amíg a sajtó ellen fellépő kormányra bukás, addig a sajtó mellett kiálló kormányra siker vár.

Bölöni Farkas Sándor franciaországi útinaplói a korlátozott királyi hatalmat, a kétkamarás törvényhozás felépítését, valamint a felelős miniszteri intézményt mutatták be. Az 1830-as júliusi forradalom után ugyanis Franciaországban megszűnt az abszolút monarchia, az ország uralkodója, Lajos Fülöp, az állam „első tis ‘tviselöje” lett, ugyanúgy viselkedik, mint az állam többi polgára: az utcán gyalog jár és meg is lehet szólítani.28

Az Egyesült Holland Királyságtól elszakadó és függetlenné váló Belgium az 1831-ben létrejövő alkotmányos monarchia intézményei miatt vált érdekessé Magyarországon, különösen az 1848-as polgári forradalom időszakában. ${ }^{29}$ A reformkori utazók, ha nem is kifejezetten célországként, de Belgiumot is útba ejtették. Bölöni Farkas Sándor találóan jellemezte a belgákat. „Amit Páriz̧s csinál, ažt csinálja Brüsszel, s Brüssz̧el után csinálják a többi belga városok. Brüsszel oly miniatúrája Párizsnak, s annyira mindenben követöje Párizsnak, hogy ami ott nagyban történik, az visszhangzile itt kicsiben, majd mindenben.” A belgák számára tehát a franciák mutatják a kibontakozás irányát; 1830. őszén Párizs mintája nyomán Brüsszel is megcsinálta „a maga revolúcióját.”’30 Az 1840-es évek folyamán Belgiumba elvetődő magyar utazók közül Tóth Lốrinc viszont részletesen számolt be a belga alkotmány alapelveiről, valamint a törvényhozás szervezetéről és múködéséről. A „követkamra” ülésén tett látogatás igen kedvező benyomásokat keltett az útirajz szerzőjében: „, $A^{\prime}$ viták elég élénken folytak, a' francziáknak saját fürgeségével's tisz̨ta, pontos és szabatos beszédével." 31

A kontinentális Európa partvidékeit elhagyva Anglia kapcsán Szemere Bertalan elsősorban a fogházakat ajánlotta olvasói figyelmébe. A hazai büntetőpolitikai reformok egyik szorgalmazójaként Angliát megjárt kortársaihoz, Bölöni Farkas Sándorhoz, Gorove Istvánhoz és Tóth Lórinchez hasonlóan, kellő részletességgel mutatta be a büntetés-végrehajtás reformjára irányuló börtönrendszerek, a hallgató-rendszer és a magány-rendszer múködését ${ }^{32}$, miközben a hazai börtönviszonyok tarthatatlanságára is felhívta a figyelmet.

Az útleírások szerzői többnyire kedvezően vélekedtek Angliáról. „Európának e’ pillanatban legérdekesebb pontja Angolhon. Oda néz minden politikai felekezęt' vezére, mint mágnestöre a' kormányos..." írta Pulszky Ferenc. ${ }^{33}$ Gorove Istvánnak kifejezetten az volt a véleménye, hogy a nagyszerűség érzete kíséri keresztül az utazót Angolhonban. ${ }^{34}$ A demokrata érzelmű Irinyi József viszont egyáltalán nem volt elragadtatva Angliától, mert bár a kereskedés és a múipar - azaz a kézmúipar és a gyáripar -

\footnotetext{
${ }^{27}$ Az esküdtszék intézményének bemutatása mások útirajzaiban, így pl. Tóth Lőrinc 1844-ben közzétett úti tárcáiban is hangsúlyos szerepet kapott.

${ }^{28}$ BÖLÖNI, Napnyugati utazás 177. 1831. március 16-i bejegyzés.

${ }^{29}$ Az 1831-es belga alkotmány rendelkezéseit és magyarországi hatását lásd ERDŐDY, A független belga alkotmányos monarchikus rendszer 7-10.

30 BÖLÖNI, Napnyugati utazás 180-181. 1831. március 30-i bejegyzés.

31 Tóth, Úti tárcza 107.

32 SZEMERE, Utazás külföldön 280 ff. 1837. június 19-i bejegyzés.

33 PULSZKY, Úti vázlatok 46.

${ }^{34}$ GOROVE István: Nyugot. Utazás külföldön. Második kötet. Pest, Heckenast Gusztáv, 1844. 117.
} 
terén az angolok bámulatos eredményeket értek el, Angliát az érdemi reformoktól ódzkodó konzervatív arisztokrácia hazájának tartotta. ${ }^{35}$ De még az Anglia iránt megmutatkozó általános rokonszenv sem volt elegendő ahhoz, hogy ne ítéljék el az angolok írországi politikáját. Az útirajzok szerzői mély ugyanis együttérzéssel írtak az Írországban tapasztalt nyomorról. Az írek fôvárosát,

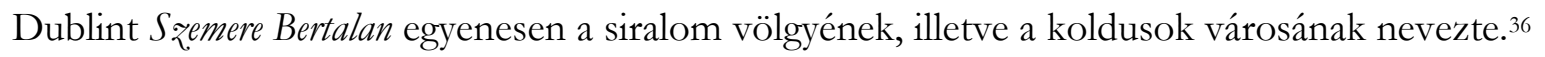

3. Az ifjú Szücs Miklós a naplóbejegyzések tanúsága szerint többször is elolvasta Bölöni Farkas Sándor észak-amerikai útinaplóját. ${ }^{37}$ Az útinapló szerzője annak idején abból a célból szelte át az Atlanti Óceánt, hogy a magyarok közül elsőként tudósítson szándékai szerint átfogó jelleggel az Amerikai Egyesült Államok alkotmányos életéről, politikai és társadalmi berendezkedéséről: „Gondolkozám, mi lehet utazásomban, mely mégis sokak figyelmét magára vonta? mert azok oly mindennapi ideák. Amerikában és Angliában, s oly sokaktól elprédikáltattak már, hogy szinte a közönséges ember is tudja, s elóttem is most éppen mindennapiak. Úgy látom, kevés magyarnak volt módja vagy kedve Amerikára fordítani figyelmét s az erróli munkákot olvasni, s mivel én a sokaktól mondottakot egybesummáżtam magyarul, ez teszi az érdeket. Meglehet, sokak csalódását elrontanám, s authorságom becse is alább szállna, de mégis szerenetném valamely íásban megvallani a publicum elött, hogy az egész. munkát csak a szeemrehányástól való félelmem szülte. Míg nem utaztam volt, mindig şitkozódtam azok ellen, kik utaznak s mégsem irják le utazásukat, s sok másoktól is ęt hallom. Mármost belébozám magam e kelepcébe, s gondolám, minden ember méltán fogja szemedbe lobbantani, hogy te is a szóvitézele közé tartozol! - és irám, amit irtam, bizony nagy részént a számadás félelme miatt." - írta naplójába már a nyugat-európai és az észak-amerikai utazásról hazaérkezvén. ${ }^{38}$

Bölöni Farkas Sándor lelkes híve volt az USA-nak. „Hatvan esz̨tendeje már annak, hogy Európának és az emberiségnek sz̨emei Amerikára vannak függesztve." ${ }^{39} \mathrm{Az}$ alapító atyák történelmi érdemeként emelte ki, hogy nem ismertek el semmiféle ,státusvallást’, hogy nincs állandó katonaság, hogy eltörölték az örökös hivatalokat, hogy nincs ,titkos polícia”, de a legfontosabbnak azt tartotta, hogy a törvényhozó, végrehajtó és ítélő - azaz bírói - hatalmat egymástól teljesen elválasztották. ${ }^{40} \mathrm{Az}$ útinapló szerzője elismeréssel írt a fogvatartottakkal szemben humánus bánásmódra törekvő amerikai börtönrendszerekről, a magányos elzáráson alapuló pennsylvaniai, illetve az örökös munkára alapozott auburni rendszerről is: „Miután Franciaországban és Angliában nehány fogházat láttam, s a bazánkbeliekre is visszaemlékeztem, az amerikaiak annyi magasztalására hittem ugyan, bogy itt csinosabb épületekben sjobb rendben tartott rossz. embereket látok - de az̧t nem is képzeltem, hogy a megjobbitásra, az. elmének és léleknek ily machinériáit lehessen feltalálni; nem véltem, hogy ezen erkölcsi machinák a megátalkodott gazemberre is ily behatással lehessenek." 41

Az amerikai demokrácia és szabadság iránti lelkesedését a rabszolgaság intézményével történt szembesülés lohasztotta le. Marylandi utazása idején olvasott ugyanis egy hirdetményt, amely a „szerecsen” rabszolgák árverését adta tudtul. „Mintha jégkéz vonult volna el szivemen ennek

\footnotetext{
${ }^{35}$ IRINYI, Német-francia- és angolországi úti jegyzetek 178.

36 SZEMERE, Utazás külföldön 355. 1837. augusztus 5-i bejegyzés.

37 „Bölöni Farkas Sándor észak amerikai utazását Pomázról magammal hozuán elolvastam, most másod ižben.” SzŰCS, Napló 112. 1841. június 7-i bejegyzés.

38 BÖLÖNI, Napnyugati utazás 557-558. 1836. február 18-i bejegyzés.

${ }^{39}$ BÖLÖNI, Napnyugati utazás 304.

40 BÖLÖNI, Napnyugati utazás 315. és 489.

${ }^{41}$ BÖLÖNI, Napnyugati utazás 362 ff.
} 
olvasására! s tehát rabszolgák országába érkętünk." - fakadt ki elkeseredésében. ${ }^{42}$ Bölöni Farkas Sándor amerikai útja idején az USA 24 tagállama közül 13 törölte el teljesen a rabszolgaság intézményét.

4. Trefort Ágost a következőképp vonta meg az 1836. évi nyugat-európai utazás mérlegét a visszaemlékezései lapjain: „Eq az utazás rendkivüli módon jó hatással volt rám, elösegitette érésemet, és évekekel öregbitett. Mint ifjonc mentem el, s mint férfi jöttem meg. Gyakorlati érzékeem kifejlödött, s nemcsak látóköröm tágult, de külsö megjelenésem is finomodott, és megtanultam megérteni a világot és az, embereket." ${ }^{43} \mathrm{Az}$ útleírások ugyanakkor a látókör tágítása révén a magyarországi reformok számára is szolgálhattak az alkotmányos eszmék és alkotmányos intézmények transzfere révén első kézből származó információkkal, illetve a közügyek iránt érdeklődő olvasóközönséget akár meg is győzhették a bevezetendő reformok szükségességéről. A realitásokkal azonban, legfőképp a szuverenitás hiányából fakadó politikai mozgástér szűkösségével, szembe kellett nézni.

Talán erre is utalhattak Erdélyi János 1845-ös franciaországi úti levelének kissé szkeptikus gondolatai: „Újabb idókben sok magyar utazik - velem együtt - a mivelt külföldön, sjobbára sikerül venni tölïk valamit az irodalomban, honunk felvirágzására szolgálót. Az ipar és keresködés meglelék szószólóikat; a boldogitási tervek nyomban érik egymást, és hála érte, van látjatok elóbb-utóbb. (...) Óhajtanám az angol keresködését, intézeteit, de abhoz egy szigetke szü̈kéges, meg egy óceán; vágynám a francia politikát, de abhoz. harmincmillió lélekbü̈l álló nemzetke szüleséges, egy világréssz̧el, mely fôvárosomra figyeljen; de az efféle vágyódásban elpárolog jobb erönk, s kivibetlenre vész lángolásunk." 44 A reformkori útleírások, útilevelek és útinaplók a földrajzi és szellemi horizont tágításával mindazonáltal nagy szolgálatot tettek, amint erre Széchenyi István sorai is rámutatnak, aki hálás köszönetét fejezte Bölöni Farkas Sándornak az észak-amerikai úti élmények közzétételéért, hiszen a könyv „haszna honosinkra nézve felsqámithatatlan.”45 Hasonló érzés keríthette hatalmába a külföld megismerése iránt olthatatlan vágyat érző ifjú Szücs Miklóst is Bölöni Farkas Sándor és Szemere Bertalan úti beszámolóinak elolvasása után.

\section{Felhasznált források és irodalom}

ifj. BARTHA Lajos: Nagy Károly, egy reformkori tudós az Újvilágban. In: Földrajzi múzeumi tan. 8. Érd 1990 BÖLÖNI Farkas Sándor: Napnyugati utazás. Napló. Válogatta, szerekesztette és a tanulmányt írta: MALLER Sándor. Budapest 1984

ERDÉLYI János: Úti levelek, naplók. Válogatta, szerkesztette és a bevezető tanulmányt írta: T. ERDÉLYI Ilona. Budapest 1985

ERDŐDY Gábor: A független belga alkotmányos monarchikus rendszer megteremtése. Jogtörténeti Szemle 2010/1. 7-10.

FENYŐ István: A polgárosodás eszmevilága útirajzainkban 1848 előtt. Irodalomtörténeti Közlemények 1964/5-6. 603612.

HALÁsz Iván: Wenzel Gusztáv és a magyar jogi komparatisztika kezdetei. Pro Publico Bono, 2015/3. 152-162.

\footnotetext{
42 BÖLÖNI, Napnyugati utazás $467 \mathrm{ff}$.

43 TREFORT, Önéletleírás 12.

${ }^{44}$ ERDÉLYI, Úti levelek 348-350.

45 Széchenyi István levele Bölöni Farkas Sándornak (Orsova, 1834. szeptember 10.), idézi: JAKAB, Bölöni Farkas Sándor és kora 297.
} 
IRINYI József: Német-francia- és angolországi úti jegyzetek. Sajtó alá rendezte és az utószót írta: FENYŐ István. Budapest 1998

JAKAB Elek: Bölöni Farkas Sándor és kora. Keresztény Magvető, 1870/4.

KAJTÁR István: A 19. századi modern magyar állam- és jogrendszer alapjai. Európa - haladás - Magyarország. Budapest - Pécs 2003

KECSKEMÉTi Károly: Magyar liberalizmus 1790 - 1848. Budapest 2008

NAGY Károly: Utazási töredékek Éjszak-Amerikából. Társalkodó 1832. december 29.

PULSZKY Ferenc: Úti vázlatok 1836-ból. In: Pulszky Ferenc kisebb dolgozatai. Sajtó alá rendezte: LÁBÁN Antal. Bevezetéssel ellátta: MARCZALI Henrik. Budapest 1914 (Erdetei kiadás: Budapesti Árvízkönyv I. köt. Budapest 1839) SzEMERE Bertalan: Utazás külföldön. Válogatás Szemere Bertalan nyugat-európai útinaplójából. Válogatta és szerkesztette: STEINERT Ágota. A tanulmányt írta: SŐTÉR István. Budapest 1983

SzALAY László: Eredetiség 's utánzás a’ politica’ mezején. Pesti Hírlap, 1844. július 17. In: SzALAY László: Publicistai dolgoztok. Első kötet 1839-1844. Pest 1847 (Reprint kiadás: Budapest 1988)

SZÉCHENYI István - WESSELÉNYI Miklós: Feleselő naplók. Válogatta, szerkesztette és a tanulmányt írta: MALLER Sándor. Budapest 1986

SZALAY László: Úti naplómból 1838-1839. V. Athenaeum, 1839. szeptember 22.

SzỨcs Miklós naplója 1839-1849. Sajtó alá rendezte és a tanulmányt írta: KILIÁN István. Miskolc 1981

TóTH Lőrincz: Úti tárcza. Első füzet. Déli Németföldön. Pest 1844

TREFORT Ágoston önéletleírása. Fordította: BARSI János. Sátoraljaújhely 1991

WeSSELÉNYI Polixéna: Olaszhoni és schweizi utazás http://mek.oszk.hu/01000/01017/01017.htm

ZÁvodsZKY Géza: Az Amerika-motívum és a polgárosodó Magyarország. A kezdetektől 1848-ig. Budapest 1992 
NAGY Janka Teodóra

Tanszékvezető főiskolai tanár

PTE KPVK
DOI: 10.15170/DIKE.2017.01.01.05

\author{
„Kulturális diverzitás és/vagy közösségi integritás?” \\ Nemzetiségek, népcsoportok és jogi kultúrák egymás mellett élése Bonyhádon
}

(18. sz. vége - 20. sz. közepe)

\section{„Cultural Diversity and/or Community Integrity?” \\ Nationalities, Ethnic Groups and Legal Cultures Living Together in Bonyhád (Late $18^{\text {th }}$ Century - Mid 20 ${ }^{\text {th }}$ Century)}

In terms of ethnographic tradition, Tolna county is one of the richest and most colourful regions of Hungary. Over the past three hundred years this territory has been occupied by seven nationalities and ethnic groups (Hungarians, Germans, Serbs, Slovaks, Jews, Gypsies, as well as the Szekelys of Bukovina and the Jasz), and five religions (Catholic, Protestant, Evangelical, Greek Orthodox and Israelite). The various communities organised on religious and ethnic grounds created a unique culture in the Valley, whose exploration and account based on specific characteristics and rules makes it particularly suitable for studying cultural diversity and community integrity, and for carrying out researches of legal ethnography, self-identified as an interdisciplinary field of science. The study wishes to contribute to the research outcomes of source communication, analysis and assessment focusing on the history of Jews living in Bonyhad, a religious community considered as the most significant for a long time alongside the communities of Buda, Bratislava and Pápa, complemented with legal ethnographical approach and complex methodology, simultaneously adding verbal information and material investigation to the written sources of legal social norms.

Keywords: legal ethnography, legal culture-history, Bonyhád, Jewish community of Bonyhád, material culture, customs and values, cultural diversity, community integrity

1. A néprajzi hagyományok szempontjából Tolna megye Magyarország egyik leggazdagabb, legsokszínúbb tája. Területén az elmúlt háromszáz esztendőben hét nemzetiség és népcsoport (magyarok, németek, szerbek, szlovákok, zsidók, cigányok, továbbá bukovinai székelyek, valamint jászok) és öt vallás (katolikus, református, evangélikus, görögkeleti, izraelita) képviselői éltek és élnek együtt.

A felszabadító háborúk után Tolna megye 15. századi 540 falujából és 21 mezôvárosából 1715-re mindössze 45-öt tartottak nyilván lakott helyként, és ezek közel fele is csak 1690 után települt újra. A 17. század végén a megye egészéhez hasonlóan a Völgység lakosságának nagyobb részét is a szerbek (rácok) tették ki, akik részben a török elől menekülve, részben nyomukban járva húzódtak az elnéptelenedett területekre. Főleg állattenyésztéssel foglalkoztak, földbe vájt kunyhókban laktak, majd a 18. századtól a terület német telepesekkel benépesülésével 
párhuzamosan délre húzódtak. A múlt század utolsó harmadában a Völgységben már csak Grábócon, Alsónánán és Szálkán, ma csupán Medinán élnek szerbek. A döntő mértékben németek lakta Völgységben - amelyet a német telepítéstörténet az ún. schwäbische Türkei részének tekintett — a főként Mercy gróf nevéhez köthető telepítések jelentős része az 1700-1740 közötti időszakra esett. A völgységi német telepes falvak többsége katolikus volt, csupán Bátaapáti, Izmény, Majos, Kismányok és Mucsfa lakossága volt evangélikus, a terület legdélibb pontján fekvő Mórágy pedig református. ${ }^{1}$ Váralja magyarsága - ahogyan Bonyhád első magyar telepeseinek közössége is református volt, a német falvak közé beékelődött többi völgységi magyar település lakói pedig katolikusok.

A zsidók a Völgység több falujában jelen voltak egy-két családdal, de nagyobb létszámban inkább Bonyhádon éltek, amelyet stratégiai hídfőállásnak is tekintettek Baranya felé. A bonyhádi zsidóság - amely hosszú ideig a budai és a pozsonyi után harmadik legjelentősebbként számon tartott hitközséggé vált - történetére, a zsidók bonyhádi jelenlétére először 1741-ből vannak adatok. A második világháború után Bonyhád zsidó lakosságának töredéke tért haza. Akik visszajöttek, azok is csak rövid ideig maradtak; 1949-től egymás után hagyták el szülőhelyüket, Budapestre vagy Izraelbe költöztek. A századforduló a német falvak viszonylagos jólétének időszaka volt, de ez csak átmenetinek bizonyult. A második világháború után a potsdami egyezmény szerint megkezdődött a Völgység német anyanyelvű és nemzetiségű lakosságának kitelepítése. A helyükre érkező bukovinai székely telepesek 1764-es madéfalvi veszedelemmel kezdődő hányatott történetének zárófejezetének tekinthető, hogy a Bácskából Magyarországra menekülők 1945-ben a Völgységben új, immár végleges otthonra találtak (többek között Bonyhádon, Cikón, Majoson, Aparhanton, Kismányokon, Izményben, Mucsfán, Bonyhádvarasdon és Kakasdon). Hagyományaikat, szokásaikat, gazdag népi kultúrájukat ma is szívósan őrzik. A bukovinai székelyek mellett a magyarszlovák lakosságcsere folytán a Völgység lankás dombjai között sok felvidékinek kellett hazát otthonra találnia, újrakezdenie.

Hinterschiedt Jánosné, született Schleier Katalin a Tolna megyei Bonyháddal szomszédos sváb településen, Majoson portörlés közben hetente kezébe vette a Hirschfeld-testvérektől nászajándékba kapott fűszertartókat, Schwarzék porcelán dísztányérjait. Miközben elnehezedő testével pörölt, immár visszavonhatatlanul elmúlt fiatalságára gondolt: a bonyhádi kereskedő Hirschfeldek, Davidovicsok és Schwarzok jutottak eszébe. A bonyhádi zsidó közösség tagjai személyes ismerôsei voltak. Mégis dermedt szemlélője maradt 1944 júliusában a több mint ezer bonyhádi zsidó gettóba, majd a pécsi Lakics laktanya, aztán Auschwitz felé tartó vagonokba kényszerítésének. A végül önmaga árnyaként visszatért félszáz pedig csak a hiányt, a fájdalmas űrt növelte. „Aqtán nébány év és mi követkęztünk ... szegény uram, baláláig testében hordta a bét év málenkij robotot."

2. A bonyhádi zsidóság, e hosszú ideig a budai, a pozsonyi és a pápai után a legjelentősebbként számon tartott hitközség története már számos forrásközlő, elemző és értékelő munka tárgya volt. ${ }^{2}$

\footnotetext{
${ }^{1}$ Református németek lakták még a megye legészakibb pontját, Nagyszékelyt.

2 BÜCHLER, A bonyhádi hitközség; EGYED, Bonyhád; EISNER, A bonyhádi zsidók; SCHWEITZER - SZILÁGYI, A Tolna megyei zsidók; SZILÁGYI, Tolna megye kereskedelme; SZILÁGYI, A bonyhádi kereskedők; BLAU, A Destroyed Community; NAGY, Néprajzi adatok; SZABÓ, A bonyhádi ózsinagóga; SZILÁGYI, A bonyhádi zsidóság; SOLYMÁR, A bonyhádi zsidóság, SzŐTS, A zsidóság; KOLTA, Zsidó diákok.
} 
A gazdag történeti forrásokhoz érdemes most a jogi néprajz szemléletével, komplex módszerével közelíteni. Az anyagi kultúra ugyanis nem csupán a tárgyak világát jelenti. Mögötte ott a közösség a maga érték- és normarendszerével. Ez teszi érthetővé és indokolttá a bonyhádi zsidó közösség anyagi kultúrájának vizsgálata során a jogi néprajzi közelítést. A jogi néprajz, mint interdiszciplináris tudományterület elsősorban, de nem kizárólag a paraszti társadalom jogi vonatkozású normáinak komplex módszerrel, az írott források, a szájhagyomány és a tárgyi emlékek bevonásával történő differenciált kutatását jelenti. Ebben az összefüggésben pedig az anyagi kultúra nem egyszerủen a vizsgálat tárgya, hanem az írott források és (amíg egyáltalán lehetôség nyílik rá) a visszaemlékezések mellett mutatis mutandis a kutatás forrása is. ${ }^{3}$ Hiszen a Völgységben a különböző vallási és etnikai alapon szerveződő közösségek olyan önálló, sajátos kultúrát - és ennek részeként anyagi kultúrát teremtettek, amelynek vizsgálata, jellemzőinek számbavétele, a törvényszerúségek megfogalmazása kifejezetten alkalmas a magát interdiszciplináris tudományterületként meghatározó jogi néprajzi kutatásokra.

Annak az etnikai és vallási sokszínűségnek, amely a Völgységet és központját, Bonyhádot ma is jellemzi, történeti gyökerei az 1700-as évekre nyúlnak vissza. Az 1728. évi összeírás adatai szerint Bonyhád újjátelepítése 1721-ben az ország különböző részeiből érkező magyarokkal kezdődött, és 1724-től német telepesek kisebb csoportjai népesítették be a települést. A zsidók bonyhádi jelenlétére - Schweitzer József és Szilágyi Mihály kutatásai szerint - először 1741-ből van adatunk: a megyei összeírásban szerepel 4 fő kereskedő. ${ }^{4}$ A türelmi adó kivetése céljából elrendelt 1746. évi zsidó összeírás szerint 11 családban 41 fő, ${ }^{5}$ 1759-ben 41 családban 149 fő alkotta a zsidó hitközséget a városban. A 19. században - a statisztikai munkák és országleírások fénykorában - a szerzők Bonyhád kapcsán három területileg, szervezetileg és szokásaiban is elkülönülő csoportról: magyarokról, németekről és zsidókról szólnak. Egyed Antal összeírása szerint 1820-ban az akkor 4709 lakosából 1631 zsidó, 1586 katolikus, 1132 evangélikus, 360 református, ${ }^{6}$ 1854-ben Fényes Elek 1566 katolikus, 1563 zsidó és 1482 evangélikus lakosról szól a mindössze 262 református mellett.

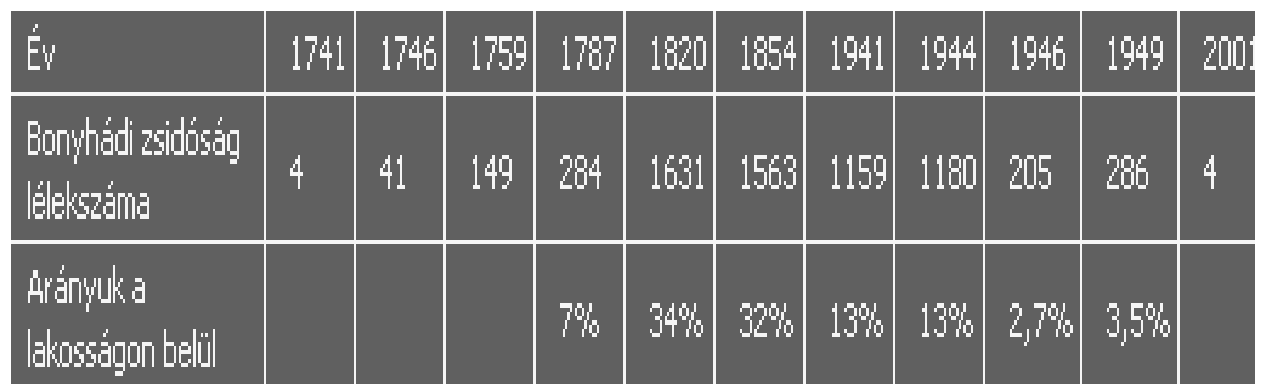

1. kép: forrás: http://www.maxnordau.com/bonyhadi-zsidosag-tortenete.php

\footnotetext{
${ }^{3}$ A témában olyan példákra hivatkozhatom, mint SOZAN, Zsidók; CSISZÁR, A szatmári és beregi aprófalvak; FARKAS, Adatok; DEÁKY - CSOMA - VÖRÖS, ...és hol a vidék zsidósága?

4 SCHWEITZER - SZILÁGYI, A Tolna megyei zsidók 148. Eisner János már 1703-ból említ ugyan sírkövet a régi, később neológ temetőből, de a folyamatos jelenlét kezdőidőpontjaként a szakirodalomban1741 elfogadott. Lásd EISNER, A bonyhádi zsidók 12 .

${ }^{5}$ Conscriptio Judaeorum Comitatis Tolnae 1746. július 6.

${ }^{6}$ EGYED, Bonyhád 7.
} 
Mivel a pécsi püspök a zsidókat nem engedte letelepedni Baranyában, így az éjszakázás szempontjából éppen megfelelő távolságra fekvő Bonyhád lett a délvidéki kereskedelem hídfóállása. Bár a hatályos jogszabályok értelmében a zsidók ekkor még nem rendelkezhettek városi ingatlannal, földbirtokkal, földesuruktól, a Perczelektốl Bonyhádon bérelhettek lakást. Bérlőivé váltak egyúttal a földesúri jogosítványoknak és haszonvételeknek is, és beépülve egyfajta „térségi etnikai munkamegosztásba” kitöltöttek egy ûrt: a földműves magyar és földműves és iparos német lakosok termékeit is értékesítették. Az 1808. évi összeírás adatai szerint a Bonyhádra Morvaországból (39\%), Csehországból (10\%), Magyarország más részeiről (29\%) és Tolna megye más településeiről (24\%) betelepülők (289 családfö) közül 152 (53\%) kereskedelemmel foglalkozott (73 ún. batyus, 19 házaló, 11 iparcikk-kereskedő)! Egyéb, elsősorban kézműves foglalkozása volt 58 családfőnek (20\%) (15 szűcs, 12 szabó, 6 üveges és pipakészító), 33 családfő (11\%) pedig az egyházközösség alkalmazásában állt (10 tanító, 6 zenész). ${ }^{7}$

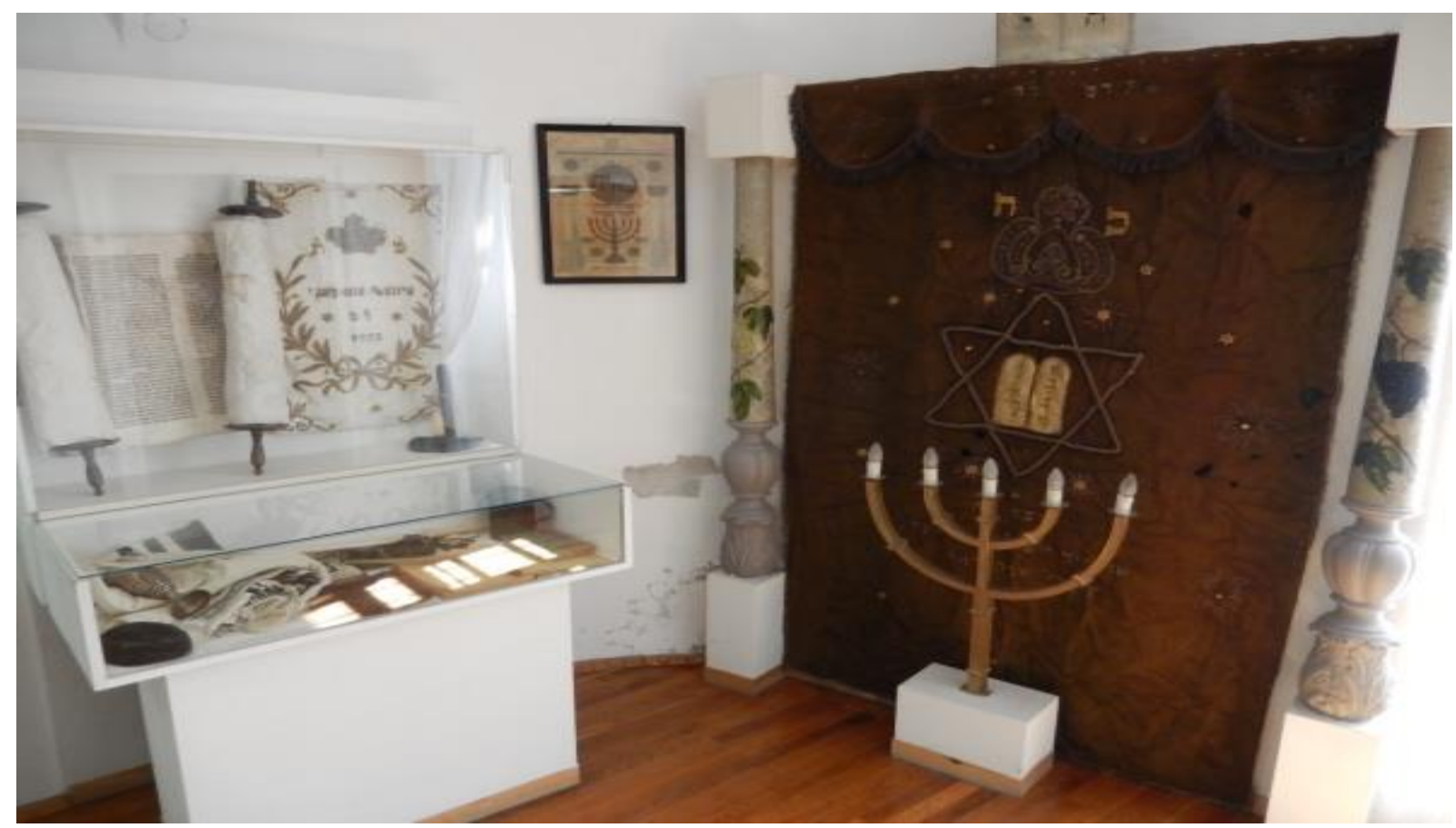

2. kép: Zsidó vallási emlékek a Völgység Múzeumban Bonyhádon (fotó: Szabó Géza).

A bonyhádi zsidóság - a döntő többségében katolikus magyarokhoz és az evangélikus németekhez hasonlóan - nemcsak a mindennapjait szigorúan meghatározó vallási szokások, életvitel és gondolkodásmód révén különült el, hanem a másik két közösséghez hasonlóan önálló igazgatási szervezettel is rendelkezett. „Vagyon Törvényházok, Birójok, Kisbirójok, Eskütjeik, Jegyzójük, éjjeli Vigyázóojok." - írta 1823-ban néprajzi szempontból oly becses híradásában Egyed Antal.8 Sajátos

\footnotetext{
${ }^{7}$ SCHWEITZER - SZILÁGYI, A Tolna megyei zsidók.

${ }^{8}$ EGYED, Bonyhád 9. Néprajzi, különösen jogi néprajzi szempontból sem érdektelen Egyednek a bonyhádi zsidók házasságkötésére vonatkozó leírása. „Házasulandók közö̈tt első lépés a moringlevél elkészitése. Ettöl függ az. Asszony jövendöbeli állapotja. Legalább két bizonyságnak alája kell irnia nevét és néba a kezesnek is. Ez. meg lévén, meghatároztatik az összeadás ideje és belye, mely akárbol lehet. A kijelölt napon és órában a Völegény az esketố ég alatt, hosszu fejér ingben a rendelt helyre megy, utána külön Nyoszolyáktól kisértetve a födött fövel vez̨etettetik a Menyasszony. Megérkęvén a Völegény vele háromszor megkerülik, mindannyiszor
} 
vonást jelentett a vallási és közösségi élettel, a szigorú vallásgyakorlással összefüggő speciális tisztségviselők köre. Ilyen volt már a 19. században a rabbi, a dajjan, a kántor, a metsző, a templomi énekes, a tanító, a templomszolga, a fürdőgondnok és a hajnali költögető. ${ }^{10}$

A vitás ügyeket Bonyhádon ki-ki a saját közösségén belül intézte el. A korabeli helyi joggyakorlatot követte Ábrahám Náthán butyoros zsidó is, amikor 1829-ben Dávid Furman butyoros zsidó elleni panaszával a rabbihoz fordult, aki „egyetértést tett’ közöttük. ${ }^{11}$ A zsidó hitközség tagjai egyébként nemcsak peres ügyeikben, de egészen köznapi, a külső szemlélő számára talán jelentéktelennek tûnő esetekben is a rabbitól kértek tanácsot. ${ }^{12}$ Fenyítő jogú zsidóbíró is működött Bonyhádon, de tevékenységére vonatkozóan sajnos csak töredékes adataink, közvetett tudósításaink vannak.13 Bisitz. Salamon bíró ellen 1848-ban többek között azért fordulnak a vármegyéhez, mert „a' birói šékeben véres Verekedést követ el’ ${ }^{14}$ Egyébként egyéni sérelmeikkel ritkán, csak valóban komoly esetben keresték meg a vármegyét. Amikor Ábrahám Náthán butyoros zsidó említett panaszával a vármegyéhez fordult, hosszan és részletesen taglalta, hogy már minden, a hitközségen belül szokásos jogérvényesítési formát igénybe vett, és a továbbiakban nincs reménye a közösségen belüli jogorvoslatra. A rabbi kétszer sikertelenül próbálkozott a békítéssel és mint írta, a zsidó bírótól sem várhatja sérelme orvoslását, mert Hirschfeld Sámuel bíró „a Furman Dávidon való 65 forint követeléséról sqóló irományt elsikkeasztotta”. ${ }^{15} \mathrm{Az}$ ügy jellegénél fogva a közösség tagjai egyénileg leggyakrabban éppen a zsidó bíró személye vagy eljárása ellen tettek panaszt. „Ha Mátyás meghalt is, nem veszett el az. Igazság, és mivel igaz ügynek. Isten is barátja, bitünk szerént most midôn a' vész. leg nagyobb, a' segély is legkëzzelebb leend." "16 Nem véletlen e megható hang, gyakorlott tónus. A bonyhádi izraelita hitközség 94 tagja által aláírt beadvány már ki tudja hányadik volt az éveken át húzódó, több fórumot is megjárt, a hitközség tagjait megosztó ügyben. Bisitz Salamon bíró, akinek egyébként komoly szerepe volt a zsinagóga felújításában, a szolgabíró és egy esküdt jelenlétében a zsinagógában „Véressen megtagolta” két vele ellentétes véleményen lévő hittársát. A

\footnotetext{
kiáltván a Mester, szerentse és áldás legyen részetek. Akkor fog Rabbinus egy borral tele poharat, hálát ad a bor Teremtöjének, s hogy az. emberi Nem szabados szaporodását szent törvényeivel elintézte. Mely végzódvén az párnak. inni ád a borból. Végre a Völegény egy aranygyürüt dug a Menyasszony ujjába mondván: a mai naptól te aze én választottam vagy. Még asztán vévé a két vének a poharat, váltva örömverseket danol, s hazakisérik az uj párt (...).” Lásd EISNER, A bonyhádi zsidók 7-8.

${ }^{9}$ „Rabbinusukat jól fizetike s betsben tartják. Ennek kötelessége minden bónapban legalább egyszer prédikáani. Házánál a Talmudot rendszerint tanitani, a Házasok. közt támadott pereket eligazitani, öket összebékéltetni, vagy ha szülkséges elválasżtani, néha örökere is, a Törvény és Fenyiték megtartására ügyelni, a házasulandókat összeadni, kétes esetekben valamely állat szabados vagy tilalmas megehetését elhatározni. A környülmetélés nem az ö dolga, ezt abhoz értő Vének viszile végbe (...).” Lásd EGYED, Bonyhád 7.

10 SCHWEITZER - SZILÁGYI, A Tolna megyei zsidók 181.

11 TML Közgyülési iratok 3:178/1829.

${ }^{12}$ Jól példázza ezt csak térben távoli eset. Egy szatmári kőmûves elbeszélése szerint, amikor a tízes években egy zsidónál dolgozott, és az építendő alap kijelölése során kiderült, hogy abba egy kis birsalmabokor is beleesik, a gazda leállíttatta az építkezést, és elment tanácsot kérni a rabbihoz. A zsidótörvények szerint ugyanis gyümölcstermő fát kivágni nem szabad. A rabbi útmutatása alapján aztán nem kivágta, hanem ,átültette” a fát. A júniusban átültetett fa természetesen néhány nap múlva elszáradt, de az építkezést a törvény teljes betartásával lehetett folytatni. Lásd CSISZÁR, A szatmári és beregi aprófalvak 173 .

${ }^{13}$ Eisner sajnálkozik, hogy a zsidó bíróra vonatkozóan rendkívül kevés adat áll rendelkezésre, amelynek okát abban látja, hogy a zsidó bíró hivatali székhelye nem a hitközségben, hanem a polgári hatóságok egyikének épületében volt, Így az iratok sem a hitközségi irattárban őrződtek meg, hanem valamely világi hatóság levéltárában rejtőzködhetnek. Lásd EISNER, A bonyhádi zsidók 95.

14 TML Közgyülési iratok 284/1844.

15 TML Közgyúlési iratok 3:178/1829.

16 TML Közgyúlési iratok 3:178/1829.
} 
temperamentumos tisztviselőt a sértetteknek járó kártérítés és a pénzbüntetés megfizetésére kötelezték, s elmozdították tisztéből. ${ }^{17}$

A hitközség, a bonyhádi zsidó elöljárók gyakran léptek fel együttesen egy-egy kérdésben. A bonyhádi zsidóközség 1814-ben könyörgő levélben esedezik a „T.(ekintetes) N.(emes) Vármegye” pártfogásáért. A háttérben Klein Jakab kegyetlen bántalmazása áll, aki a „tüz által tsaknem vég képpen elpusztittatott volna”, és adósságai fejében „nem tsak hogy (...) hátramaradott kevés vagyonát elszedték volna, hanem az Te(kin)-t(e)tes Uradalmi Uriszékenek. kegyes végzése szerént annak személye is által adott volna: ugy hogy utoljára Vason több hetekig kinozván verték és annak utána meg feleségét és gyermekét is hurczolták, ugy annyira, hogy a nagy ijedtségben el futott gyermeknek egész. mostanáig hollétét' nem tudni. ${ }^{18}$

Ez az eset már átvezet a zárt zsidóközösség külső megítélésének kérdéséhez. Itt és most nem az ismert történeti, politikai tényekről kívánok szólni, hanem a Bonyhádon élő különböző közösségek együttélése során keletkező kapcsolatokról, esetleges konfliktusokról. További kutatásra érdemes az a körülmény, hogy vallási villongásokra, egymás szokásainak megsértésére az írott források között viszonylag kevesebb adatot találni. Az előforduló ilyen esetekben is azt tapasztaljuk, hogy a zsidók nem a helyzet élezésére, hanem az ellentétek elsimítására törekedtek. Amikor például 1834-ben Kiszely Ádám bonyhádi megyés pap azt panaszolta, hogy a zsinagógában is kihirdetett királyi parancs ellenére Böjt előhavának 22. napján „a zsidó Kalmár Ifjúság, minden tilalmazásom ellen nagy táncot s' muðsikát tartott, Ugy bogy a Hintoknak s' Kotsiknak egész Éjjeli šörnyü döngései miat, a Mellyeken Szépeiket az. Utcákon fel s' alá hordozták, Éjjeli tsenden nyugodalminkban háborgattak”, a zsidó hitközség elöljárói azzal tértek ki a vita elől, hogy ők maguk is figyelmeztették az ifjakat, „mivel azomba' azok a Földes Uraságoktol a kereset kortsmánál való mulatságra engedelmet nyertek, tovább öket nem akadályozhatták". ${ }^{19}$

Az anyagi kultúra vizsgálata szempontjából különösen figyelemre méltóak a bonyhádi zsidó hitközségnek nagyszámú közösségi épületei, a hitközségi élet terei. Ebben az anyagilag gyarapodó közösségi tagok hozzájárulásai mellett fontos szerepe volt a földesúri támogatásnak. ${ }^{20} \mathrm{Az}$ első imaházat az 1745 - 1768 között Bonyhádon rabbiként működő R. Jichok ha-Lévi Spitz. (Jichak Spitz) építtette 1764-ben. ${ }^{21} \mathrm{~A}$ folyamatosan gyarapodó közösség mind gyakrabban hangoztatott zsinagóga építési terveit az 1794-es tűzvész tette aktuálissá, amelyben leégett az istentisztelet és imaalkalom helyszínéül szolgáló épület, a lángok martalékává váltak a hitközség kegytárgyai. ${ }^{22}$ Az új zsinagógát,

\footnotetext{
17 TML Közgyúlési iratok 3:178/1829.

18 TML Közgyúlési iratok 11:15/1814.

19 TML Közgyúlési iratok 373/1834.

20 1743-ban Schilson a birtok egyik felét Perczel Józsefnek és apósának, Gaál Sándornak, majd 1755-ben Schilson a bonyhádi uradalom másik felét is eladta a Kliegel családnak, aki a Perczelekekel együtt a hitközségi építkezésekhez területet és támogatást nyújtott a megtelepedett zsidók számára. Kezdetben azzal, hogy épületet adott bérbe imaház céljára, majd 1794-ben mindkét földbirtokos beleegyezett, sőt pénzzel is támogatták az új zsinagóga építését, 1814-ben pedig a Perczelek lehetővé teszik, hogy épületet vásároljon a hitközség rituális fürdő, elemi iskola és szolgálati lakás céljára. Lásd SCHWEITZER - SZILÁGYI, A Tolna megyei zsidók 185.

${ }^{21}$ SZABÓ, A bonyhádi ózsinagóga 46.

${ }^{22}$ „A pusztitó lángözön elérte Szentélyed / Hol néped zengte dicsôséged. / Leomlottak a megszentelt falak / És házad eltünt az üszkö̈. alatt! / Szzent Tanod tekercsei, szépséges Toráid / Aranyszöttes rubäid, ezüist kegysžereid, / Sok-sok talit és tfilin, sz̧ent imakönyvek, Régi nagy magidok, bires zsidó bölcsek / Könyvekbe foglalt mély és nagy tanitásai: / Megsemmisitették a tüz vörös lángjai! / Megölt a lán mindent, mit elért?' Részlet Abrahám Jebuda léb Freistadt (Ábrabám Freistadt) rabbi az első bonyhádi templom elpusztultának emlékére írt gyászénekéből. Közli: EISNER, A bonyhádi zsidók 20.
} 
amelynek építése 1795-ben kezdődött, és amelyet 1868 után a neológ (kongresszusi) hitközség használt, ${ }^{23}$ Egyed Antal az alábbiak szerint írta le: „Zsinagógájok nagy négyszögü épület. Tömve vagyon egyes mozgatható székeekekel, meljeket megszorulván a tulajdonos, néba nagy áron el ád, vagy zálogba vet. A Rabbinus belye külön és emeltebben vagyon. az asszonyok és hajadonok ki lévén a zsinagogából qárva, a felsó emeleten jönnek. össze. A bemenetelnél viz̧tartó áll, hol kiki megmosdik, a férfiak, felteszilk háromszögletü kis kalapjokat, különös lepelt takarnak magokra és igy ábitatoskodnak. Hol halkan imádkoznak, majd a Mester után énekelnek. Isteni szolgálatra egy ere a végre rendelt Zsidó Férfi által bivattatnak, ki minden báz kapuját egy kéą̧en levö kalapátssal döngeti és az összejövetel óráját kikiáltja (...)"24 Az ortodox zsingagóga 1924-ben épült, a telek adományozója Kábáne Áron, építője Krausz. Salamon volt, 1955-ben még naponta imádkoztak benne. ${ }^{25}$

A bonyhádi hitközség 1798-tól iskolát tartott fenn, ahol németül és magyarul is tanították a gyermekeket. ${ }^{26}$ A különválást követően, 1868-tól pedig a neológ és az ortodox hitközség is múködtetett 6-6 osztállyal népiskolát. Ezek mellett több magánkézben lévő zsidó elemi iskoláról (héderről) tudunk Bonyhádon, ahol a betűvetést és az olvasást tanították (1851-ben pl. 12 található a városban). A hitközség által működtetett bonyhádi Talmud iskolának (jesiva) különösen jó híre volt. A Morvaországból érkezett Jichak Spitz rabbi vezette, a Chevra Kadisa hatalmas épületében 1750-1768 között működő jesivába Kolozsvárról, Szatmárról, Dunaszerdahelyről, Pozsonyból, Bécsből is érkeznek a nagytudású bonyhádi rabbikra kíváncsi diákok. ${ }^{27} \mathrm{~A}$ bonyhádi jesiva bejárati ajtajánál elhelyezett kőtábla szerint az 1795-ben épített zsinagóga mellett álló épületet „Tóratanulás és ájtatoskodás céljára" adományból építették 1801-ben. ${ }^{28}$ Az épület a hitközség kettéválása után

\footnotetext{
${ }^{23} \mathrm{Az}$ új zsinagógát 1795-ben kezdték építeni: a tarcali után (1779) a második legkorábbi (1795-1796), a mádival (17951798) azonos időszakból származó műemlék. A feljegyzések szerint a hitközség tagjai maguk faragták a köveket, a pallérok és a munkások is a bonyhádi hitközség tagjai voltak. Az építést követô évben már használatba is vették az elkészült új templomot, amelyen 1847-ben végeztek rekonstrukciós munkálatokat. A zsinagógát 1868-tól a neológ (kongresszusi) hitközség használta, 1896-ban felújították, 1923-ban pedig visszahelyezték a korábban elmozdított bimát az eredeti helyére. Egy híradás szerint 1955-ben szombatonként még imádkoztak benne és megvoltak a hitközség könyvei. Lásd LÖWINGER - SCHELZER, Jelentés 59. „Többszáz barna börkötésü foliáns sorakozott a kongresszusi bitközség templomában levô tanácsterem könyvespolcain.” Lásd EISNER, A bonyhádi zsidók 103-104. A tetőszerkezetet az állami tulajdonú épületen 1987-ben felújították, az 1990-es években a város üzemeinek raktárhelyisége volt. A belső zsinagógai teret több mint 15 évig cipőgyári készáruraktárként használták, az előcsarnokban 1992-től éveken át takarmánybolt üzemelt. Lásd SZABÓ, A bonyhádi ózsinagóga 49-50. Magántulajdonba kerülését követően is raktár volt, 2002-ben vol egy részleges felújítása. A közelmúltban változás történt a tulajdonviszonyokban (a szóbeszéd szerint egy pókerpartin nyerte el az új tulajdonos). Az épületet kitakarították, majd 2014. július 3-án a bonyhádi holocaust 70. évfordulójára emlékezve a zsinagóga előtt elhelyezett emlékmű avatásával egybekötve kiállítással (Elfelejtett arcok) és műsorral megnyitották a közönség számára.

24 EGYED, Bonyhád 7.

${ }^{25}$ LÖWINGER - SCHELZER, Jelentés 59. Jelenleg szintén magántulajdonban van, bútorraktárnak használják.

${ }^{26} \mathrm{~A}$ zsidó hitközségekben a kisgyermek három éves korában kezdte elsajátítani a héber ábécé betűit. „Ötéves korban keeqdi a gyerek tanulni a Bibliát. Tizéves korban a Misnát. Tizenhárom évesen köteles a parancsolatokat betartani (bár micvá). Tizenöt évesen a Talmudban búvárkodik. (...).” (Misna)

27 MOsKOVITS, Jesivák.

${ }^{28}$ Ennek a helyén avatták fel 2014. július 3-án Pasitka Hermann Holokauszt emlékmûvét, amelyen a két vasúti sín a szörnyü utazást szimbolizálja, a betontömb a kegyetlen hatalmat, az 1222 áldozat nevét tartalmazó üveglap pedig az emberi élet törékenységét.
} 
neológ népiskola lett, a héder és a jesiva ezt követően ortodox irányítás alá került, az ortodox hitközség héderjében továbbra is 6-8 tanító (mölámed) oktatta a különböző korú gyermekeket. ${ }^{29}$

A zsinagóga közelében volt a rituális fürdő (mikve), amely meglétét már Egyed Antal is megemlíti 1823-ban: „A zsidóknak derék fürdőházok tavaltól fogva, két emeletre, hol a közönséges asszonyokmártóján kivül, hat kád vagyon a fürödni akarók alkalmatosságára." 30 Arra is van adat, hogy a zsidó rituális fürdőt bonyhádi keresztények is használták - átalányt fizetve érte (évi 15-31 forintot). ${ }^{31} \mathrm{Az}$ 1920-as években a neológ hitközség mikvéjét megszüntették (az okok között szerepelt, hogy felújításra szorult, kevesen használták, stb.), a továbbiakban térítés ellenében ők is az ortodox fürdőt használták.

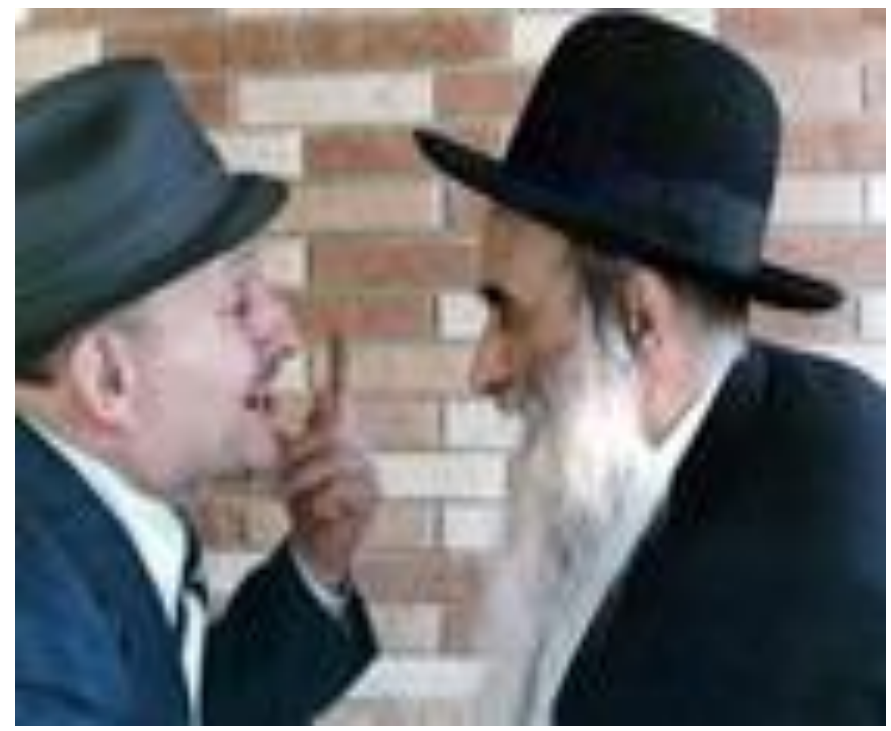

Mindkét felekezet rendelkezett maceszsütödével, ahol a húsvéti kovásztalan kenyeret készítették. A neológ hitközség azonban a harmincas években már nem újította fel a sajátját, hanem a budapesti hitközségtől szerezte be az ünnepi ételt. ${ }^{32} \mathrm{Az}$ ortodox hitközség maceszsütödéje viszont a mai napig megvan.

3. kép: Guttman Jenô érvelését Rabbi Breuer Dávid hallgatja a tóraavatás idején (forrás: http://www.bozsiho.com/galeria.html).

A zsidóknak Bonyhádon már 1754-ben volt menhelyük és kórházuk, ahogyan múködött a Chevra Kadisa is. Ez utóbbi egykori épületét vette meg az evangélikus egyház és használta gimnáziumként1870-1904 között. ${ }^{33}$ A bonyhádi Chevra Kadisa előzményeiről keveset tudunk: 1754-ben Gumprich ben Shuel új alapszabályokat fektetett le, amelyek a betegség, a kórházi ellátás és a halál esetére szóló gondoskodás alapelveit határozták meg. ${ }^{34}$ A temető udvarán 1820-ban már

\footnotetext{
${ }^{29}$ A Bonyhád, Vörösmarty u. 24. sz. házban a két világháború között az agg Ausch Izsák és a javakorabeli MárkuszJózsef kereskedők magánjesivát tartottak fenn.

${ }^{30}$ EGYED, Bonyhád 7. Hozzáfüzi később: „Feljebb emlitette, hogy a Zsidó községnek Bonybádon fürdôháza vagyon. Itt az. a hely, bol tisztulások után a Zsidó Asszonyok megmártják magokat. Egészen le kell a víz alá bukniok, ugy hogy a víz a fejök felett elcsapjon, $s$ ezt edig a legkegyetlenebb télben is, fagyos vižben minden hónapban tenniök kellett. Most már ęt a vižet is melegitik." EGYED, Bonyhád 9.

31 Többek között Perczel Sándor, Perczel Gábor, Perczel Borbála, Döry György, báró Wimmersperg. Lásd EISNER, A bonyhádi zsidók 107.

32 A neológ macesz sütöde jellegzetes alakja volt Bárány József, aki egész évben csendes, kevés szavú batyus házaló volt, de a sütödében, a „maceszházban” igazi parancsnokként, a liturgia megfellebbezhetetlen őreként viselkedett. Bővebben: EISNER, A bonyhádi zsidók 105.

33 Miután az új gimnázium elkészült (1904), a Chevra Kadisa épülete, amelynek egyik felét az 1970-es években lebontották, más iskoláknak adott otthont.

${ }^{34} \mathrm{~A}$, ,S žnt Egylet’’ szegény sorsú betegek szervezett gondozásával, gyógyszerezésével, a holtak eltemetésével és emlékük vallásos megőrzésével foglalkozott. Szilágyi Mihály a bonyhádi izr. hitközség Chevra Kadisa alapszabályai 1888.
} 
kórház jellegű szegényházat építettek, amelyet 1868-ban felújítottak. A neológ hitközség a 19. század második felétôl múködtette a sütöde szomszédságában ma is látható egykori Szeretetházat, amelyet azonban még a századforduló előtt eladtak. Ezt követően csak a metsző lakásában tartottak fenn két szobát a hozzátartozók nélküli egyedülálló rászorulóknak, akiknek élelmezéséről úgy gondoskodtak, hogy „napokat” ehettek a hitközség ,jószívî̉” tagjainál. ${ }^{35}$ A kettéválást követően a Chevra Kadisa is megkettőződött, de számos közös pontot találtak a hitközségek tagjairól gondoskodás, a temetőlátogatások és gondozások területén.

Bár a legkorábbi sírkövet 1703-ra datálták, ami biztos az, hogy a régi zsidótemető 1768 előtt jött létre. Ebben az évben már bővítéséről szólnak a források, majd 1783-ban ismét. ${ }^{36}$ A halottasházat, amely mai is ott áll a régi (utóbb neológ) zsidó temető Vörösmarty téri bejáratával szemben, 1793-ban Moshe Jichák és felesége Eszter adományából építették. ${ }^{37}$ A zsidók sajátos helyzetét tükrözi Bonyhádon az is, hogy az országos gyakorlattól eltérően temetőjük nem a településen kívül, hanem közvetlenül a katolikus temető mellett, attól egyetlen fallal elválasztva helyezkedik el. ${ }^{38}$ Figyelmet keltő, hogy a temető-kert elején van egy sír külön elkerítve: a szájhagyomány azt tartja, hogy a perlekedő tagot a hitközség és a Chevra Kadisa csak a parcellákon kívül volt hajlandó eltemetni. ${ }^{39}$ A régi (neológ) temetőben található Boskowitz. Wolf rabbi sírja. A háztető formán elhelyezett két nagy kőtábla nyilásába ejtik be a hívők közel két évszázada titkos kívánságaikat tartalmazó céduláikat (kvitli). A különváló ortodoxok csak 1879-tôl temetkeztek új, a katolikustól délre fekvő temetőjükbe. A neológ hitközség tagjai 1947-ben állították fel az „Emlékęés Falát' a régi temetôben.

A három etnikai közösség Bonyhádon - kisebb-nagyobb változásokkal - a huszadik század közepéig a kölcsönös gazdasági egymásrautaltság függvényében élt. A továbbiakban egy sváb falusi közösség és a bonyhádi zsidók érintkezésének néhány területét kívánom számba venni a harmincas évek idején. A választott település Majos, melynek bár nem volt zsidó lakossága, azonban a falubeliek Bonyhád közelsége miatt többféle módon is kapcsolatba kerültek a zsidókkal.

A majosiak a szükséges cikkeket általában a falubeli boltokban, a vásárokon és a bonyhádi piacon vették meg, de egy-egy ünnepi alkalom vagy komolyabb vásárlás esetén a bonyhádi kereskedőkhöz is elmentek. 40

pontjára hivatkozva 1753-ra teszi a bonyhádi egylet megalakítását. (TML Zsidó egyletek) SzILÁGYI, A bonyhádi zsidóság 51.

35 Az egykori Szeretetház ma is látható a Rákóczi u. 7. sz. alatt. EISNER, A bonyhádi zsidók 54.

${ }^{36}$ EGYED, Bonyhád 10. „Meghalván valaki közülïk, egy arra rendelt des₹łkára fektetikés megmossák. Azután tiszta fejérbe öltöztetik. és még lepedöbe is takargatván igy a Szent Mibály lován fekete posztóval bévonva a temetöbe viszilk. Mind a két nemen levök a nöket, de asszonynak a férfi temetését követni nem szabad. A sir oldalai deszkázva vannak, de feneke nintsen. Beléeresztik a bolt testet hanyat egyenesen elegyengetik, s rátétetvén a fedél földel behányják. Különös hogy azon Házbelieknek, honnan valaki kihal nyolc egész, nap a földön kell ülniek. Semmit dolgozniok nem szabad, s enni is más házaktól kapnak.” EGYED, Bonyhád 8.

${ }_{37} \mathrm{Az}$ épület bejárata felett elhelyezett emléktábla szövege magyarul: „A S rent utjai és tettei igazságosak! Izrael birája hatalmas!" Közli: EISNER, A bonyhádi zsidók 49.

${ }^{38}$ Ezt a falat Kliegel Ignác földbirtokos építette 1800-ban, amikor megengedte a zsidóknak, hogy a katolikus temetőig terjedjen a temetőjük.

${ }^{39}$ EISNER, A bonyhádi zsidók 50 .

${ }^{40}$ Grieszháber a majosiakat jellemezve az alábbiakat emeli ki. „Bizonyos kereskedelmi szellem fejlódött ki benne, s ügyesen tudja terményeit értékesiteni. Talán a fejlett bonyhádi piacnak közzelléte váltotta ki belölïk ę̧t a lelki sajátosságot. Vonatkozile ez különösen az asszonynépre, de megvan a férfiakban is. A bonybádi piacot akár van dolga, akár nincsen, megtekinti, s ha alkalom kinálkozike jó üzletre, azonnal intézkedik." Lásd GRIESZHÁBER, Majos. 


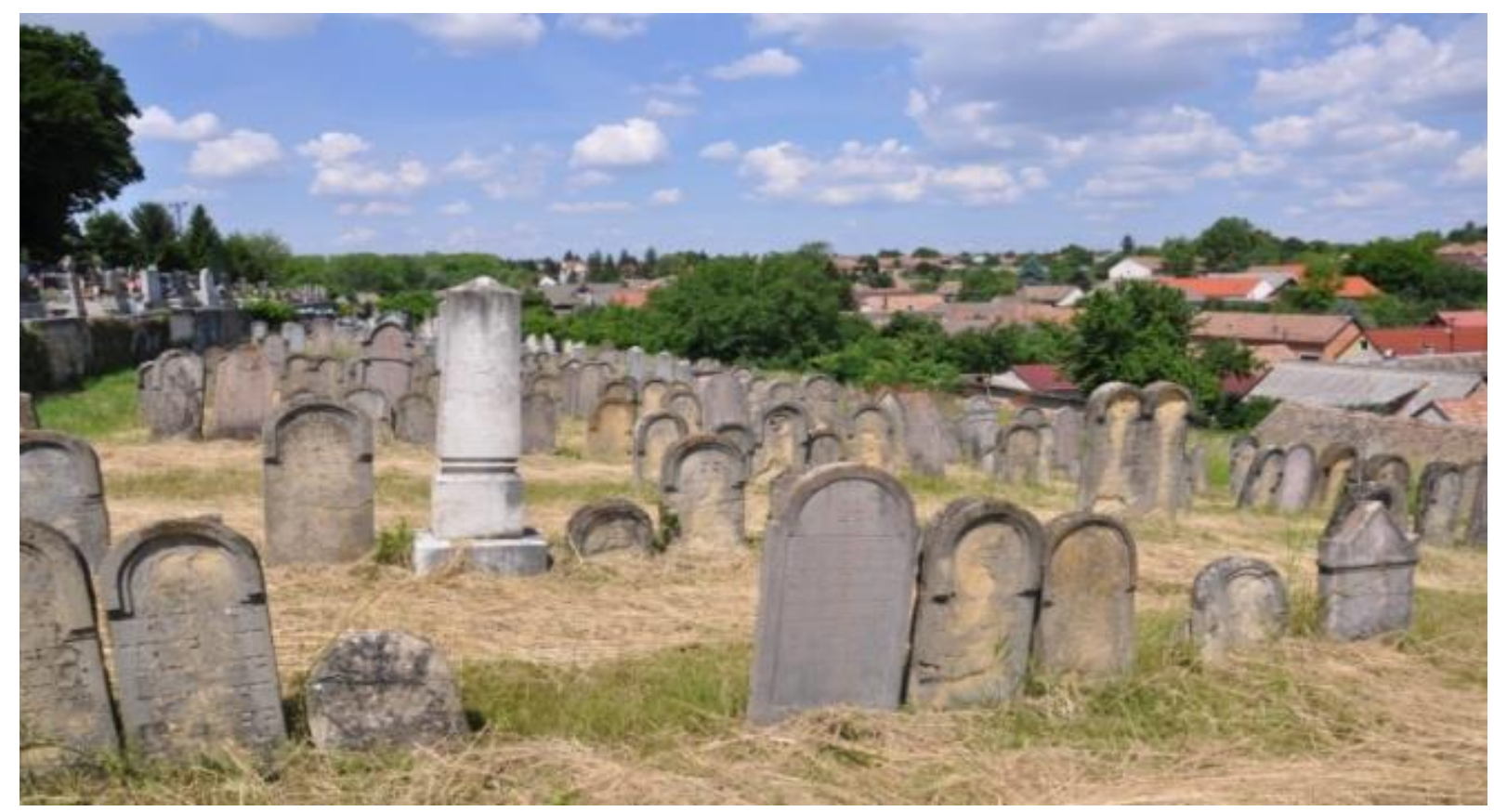

4. kép: A bonyhádi régi (neológ) temető (fotó: Szabó Géra).

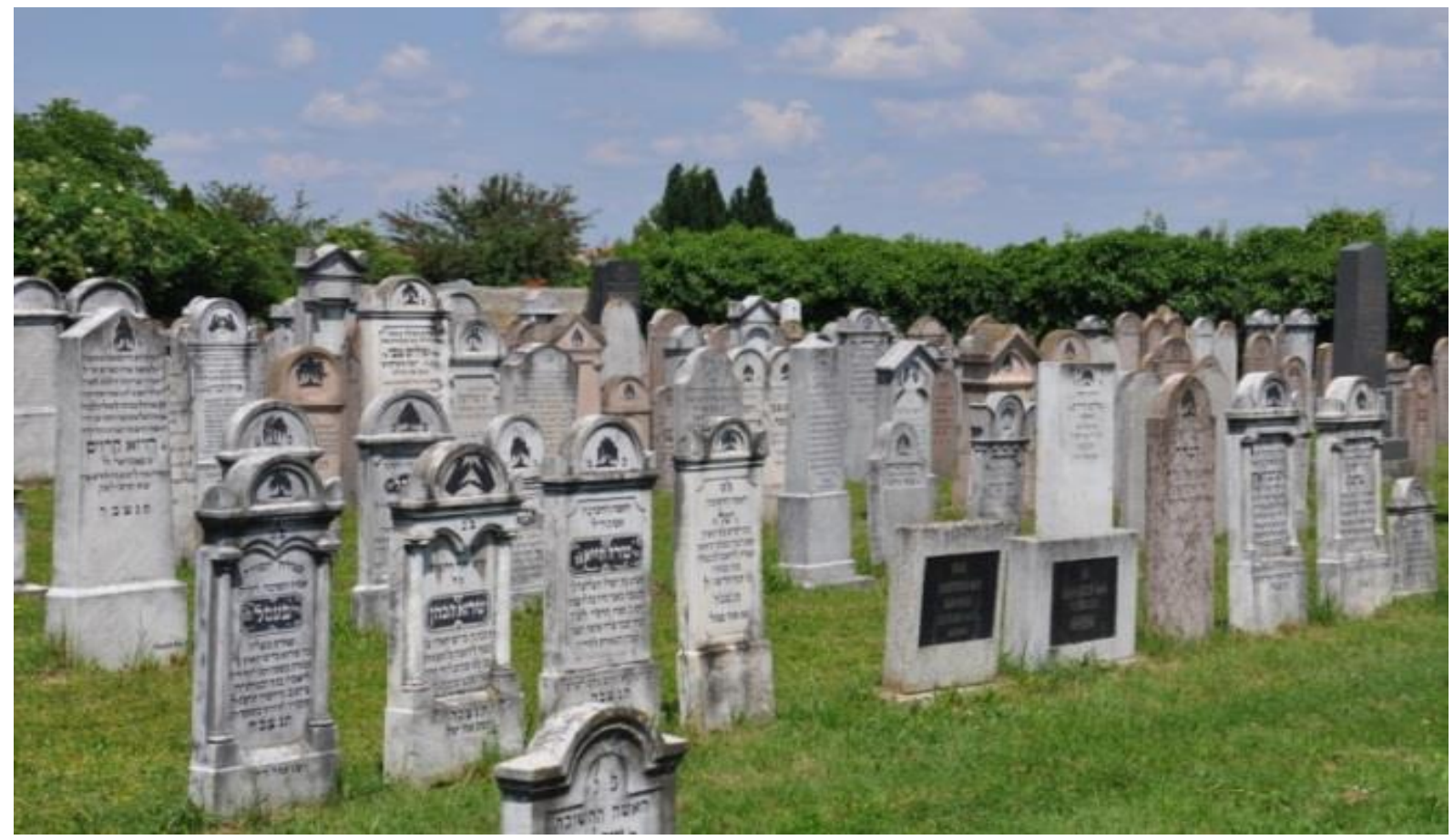

5. kép: A bonyhádi új (ortodox) temető (fotó: S₹abó Gé₹a).

A faluban 3 bolt múködött: a „Hess”, a „Schuláf” és a „Schleier". Mindhárom boltot majosi sváb tulajdonosuk után nevezték el. Hesséket takácsként is számon tartották, mert az üzlet mellett rongyszőnyeget és ,pacskertalpnak valót’ szőttek. A szőnyeget vásárra vitték, a ,pacskertalpnak valót’ 
a faluban értékesítették. A „Schuláf” tulajdonosa egy hadirokkant férfi volt. Schleier Jakabné (1900 1980) a mai „gumigyár" melletti házban bérelt egy helyiséget. A férje asztalos volt, mindketten Bátaapátiból kerültek a faluba. A boltok a kora reggeli órákban és este tartottak nyitva. Különösen reggelente volt nagy a forgalom, amikor az asszonyok, miután leadták a tejet a tejcsarnokban, bebetértek élelmiszerért, vagy a ház körül hiányzó apróságért. A majosi sváb boltosok áruikat a bonyhádi zsidó kereskedőktől szerezték be. Schleier Jakabné lánya szerint anyja kéthetente ment be Bonyhádra. Ilyenkor kocsit fogadott, s azzal hozatta haza az árut. Legtöbbször a Davidovicstestvéreknél vásárolt, de cukrot, sót s más effélét a Hirschfeld-testvérektől vett. ${ }^{41}$ „Schwarznál mindig megállt az ecet miatt.” Bárány Simonnál ruhaféléket, csipkéket, gyapjút vásárolt. A zsidó kereskedők udvariasak voltak, hozzá, mint gyerekhez is mindig volt egy-két kedves szavuk. ${ }^{42}$

A majosi parasztasszonyokhoz gyakran beköszöntek a házaló tollas vagy rongyos zsidók. A rongyot, vagy ami a háztartásban felesleges volt, egy Adler nevú bonyhádi zsidó vitte el, akinek „rossz lába volt”. Volt egy batyuja, azzal járt házról házra. Ha rongyos lett a pacsker talpa, nem foltozták meg, hanem az öreg ruhákkal, rongyokkal együtt odaadták a zsidónak, aki cserébe tút, bögrét, egy- vagy kétdecis kis üvegpoharat adott. Nem volt pontosan meghatározva, hogy mennyiért: „Összeszedtem a régi ruhát, ö meg adott valamit”. Volt egy tollas zsidó, az is bögrét, ezt-azt cserélt. Az egyik adatközlő még mindig használ egy hajdan gyerekkispárnáért cserélt olcsó porcelán, lilarózsás bögrét, amit valószínűleg Englmann Adolf bonyhádi üveg- és porcelánáru kereskedéséből szereztek be a zsidó házalók. ${ }^{43}$ Emlékeztek arra is, hogy egy zsidó kocsival járta a falut. „Nyúlbört, meg kecskebőrt vásárolt." Később az élelmesebb cigányok kapták hátukra a zsákot. Először csak régi ruhát, tollat vettek - volt, aki éppen valamelyik bonyhádi zsidó megbízásából -, aztán mindent, ami eladó volt. A cigányokat, akik gyakran be is csapták őket, sokkal erőszakosabbnak tartják, mint a régi zsidó házalókat: „Összeszedte az ember a tollat, de nem adtak semmit se jóformán. Meg is mondtam, hogy máskor nem adom oda. Egy dunyháért nébány éve is csak száz forintot kaptam. Nem is akartam odaadni, de ö már feltépte, s néżte a tollat."

Régen a majosi lányok, asszonyok közül sokan dolgoztak Brick, Guttmann és Frölich bonyhádi telepén. Rongyot és gyapjút mostak, báláztak. A bonyhádi zsidókkal szinte kizárólag csak gazdasági tevékenységük során érintkező környékbeli majosi svábok a zsidók családi életéről általában keveset tudtak. A zsidó asszonyokat csak a boltok pénztáraiból ismerték, a gyerekekről azt tudták, hogy külön iskolába járnak. Életmódjukat, szokásaikat kevéssé ismerték, de az köztudott volt, hogy szombaton nem dolgoznak, s ezért az esetleges nagyobb bevásárlásokat más napra időzítették. Ritka kivételnek számított az élet egyéb területein való érintkezés, mint például amikor Schleierné lánya lakodalmára meghívta azokat a zsidó kereskedőket, akiknél vásárolni szokott. Ök részt is vettek a templomi szertartáson, megajándékozták a menyasszonyt, de nem fogyasztottak semmit. „Mi elhivtuk a lakodalomba a Hirschfeld-tesvéreket, a Bárányt és a Schwarzot. A templomban ott voltak, de biába kináltuk öket. Átadták az ajándékot, és elmentek. A Hirschfeld-testvérektöl egy kendöt, 6 nagyobb és 6 kisebb füszertartót, Báránytól 6 darabos evökészletet, Schwarztól négy kis porcelán dísztányért kaptam."

\footnotetext{
41 SOLYMÁr, A bonyhádi zsidóság 62; SzŐTS, A zsidóság 70.

${ }^{42}$ A bonyhádi zsidó kereskedőkkel részletesen foglalkozott tanulmányában Szilágyi Mihály és Solymár Imre. SZILÁGYI, A bonyhádi kereskedők; SOLYMÁR, A bonyhádi zsidóság.

${ }^{43}$ SZILÁGYI, A bonyhádi kereskedők 94.
} 
3. A bonyhádi zsidó hitközség ma már csak emlék. Az írott források, a visszaemlékezések és a tárgyi emlékek egymást erősítve, kiegészítve arról beszélnek, hogy a zsidóság életvitelét és gondolkodásmódját szigorúan meghatározták vallási szokásaik. Az étkezésben, a munkarendben, a mindennapok cselekvéseiben megnyilvánuló kötöttségek kifejlesztették bennük az analizálás, a pontos helyzetértékelés képességét. A vallási törvények és a mindennapi élet helyzeteinek ellentéteire való folytonos megoldáskeresés sajátos észjárást alakított ki, amely szívóssággal párosult. Nem ismertek lehetetlent. Minden helyzetben megpróbáltak megoldást keresni - ha érdekeik úgy kívánták. Szigorúan ügyeltek az együttélés szabályainak megtartására, figyelmet fordítottak társadalmi kapcsolataik ápolására. Kiszolgáltatott helyzetük, foglalkozásuk alapos emberismeretet követelt, fejlett alkalmazkodóképességet feltételezett. Mozgékonyak voltak, családi, kereskedelmi kapcsolataik nem ismertek országhatárokat. A kedvező körülmények között néhány generáció alatt évezredes stratégiájuk, szigorúan hagyományozott kultúrájuk, tapasztalataik révén a 19. században a Völgységben kialakult munkamegosztásnak részeseivé, rövid idő alatt a gazdasági élet meghatározóivá váltak.

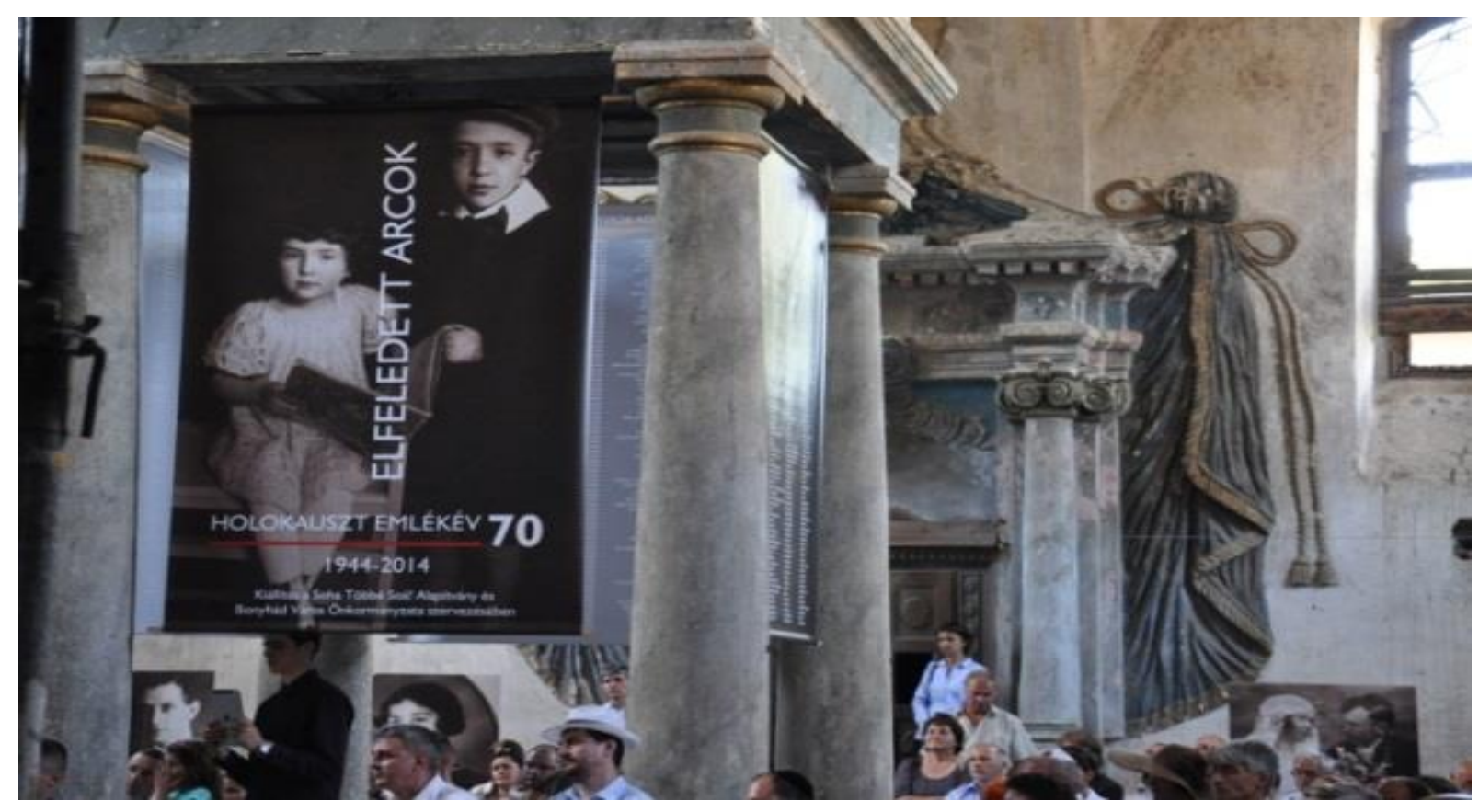

6. kép: Emlékkiállitás a Holocaust 70. évfordulóján a bonyhádi régi (neológ) zsinagógában 2014. július 3-án (fotó: Szabó Géza).

Bonyhádon 1741-ben még csak 4 zsidó lakost írtak össze - 2001-ben már csak ugyanennyien éltek a városban. A bonyhádi zsidó hitközség története, alakulása, formálódása a két időpont között eltelt 260 esztendő alatt a jogi néprajz interdiszciplináris megközelítése tükrében továbbgondolásra érdemes.

A bonyhádi zsidóközösség tagjai a 18. század második felében több hullámban, de alapvetően a Habsburg Birodalomból, illetve annak örökös tartományaiból, többségükben (50\%) a morva-cseh területekről érkeztek és közös műveltségbeli, nyelvi és gazdasági háttérrel rendelkeztek. 
(Rabbijaikat is mindvégig német és morva területekről választják.) Az itt letelepedők másik felét azok a magyarországi és környékbeli zsidók jelentették, akik szintén elsősorban a Mária Terézia által igazgatott Habsburg Birodalom polgárai voltak, legfeljebb már némi helyismerettel rendelkeztek az újra benépesedő Swäbische Türkei területén.

A zsidók völgységi betelepülése egy demográfiai vákuumba, egy népességváltás, illetve újrarendeződés folyamatába illeszkedett. A török alól felszabadított terület, így Bonyhád és környéke benépesítése is a 18. századtól elsősorban magyarokkal, majd német nyelvterületről származó „svábokkkal’ történt. A nyugati típusú, német kultúrkörből érkező zsidóságot nemcsak a nyelv közössége kötötte össze velük, hanem a már meggyökeresedett, de még nem tősgyökeres völgységi svábok megkönnyíthették számukra az új környezetbe való beilleszkedést is.

Egy többnemzetiségű környezetben immár harmadik közösségként könnyebben elfogadtatták/elfogadták etnikai, vallási és nyelvi különbözőségüket, sőt generációkkal később közvetítői szerepvállalásuk sikerének visszajelzéseként előfordult, hogy a mérleg nyelvének szerepét is betöltötték a város életében.

A bonyhádi zsidók jól beilleszkedtek a kialakuló térségi etnikai munkamegosztásba is: a nagyobb arányban katolikus, kisebb részben református magyarok kizárólag földművelésből éltek, a svábok földművelésből és háziiparból. A bonyhádi zsidók terményeik, termékeik értékesítését vállalva (a zsidó családfők 50\%-a kereskedelemmel foglalkozott az 1808. évi népesség összeírás szerint) betöltötték azt az űrt, amely az itt élők gazdasági tevékenységében keletkezett - és egyben a saját maguk teremtette kereskedelem haszonélvezőivé is váltak.

Megtalálták helyüket komplementer tevékenységük révén a terület társadalmi-gazdasági struktúrájában is. A nyugat-magyarországi típusú bevándorlással érkezők számára kedvező helyzetet teremtett, hogy Bonyhád földesurai fogadták be őket. A Perczelek és Kliegelek felismerik, hogy az ideérkező zsidók gazdasági és kereskedelmi tapasztalatai az adott időszak gazdasági modernizációja, a majorsági gazdálkodás időszakában rendkívül jól hasznosíthatóak, illetve a földesúri jogosítványok és haszonvételek számukra bérbeadása gyorsan megtérülő gazdasági haszonnal jár.

A döntően osztrák örökös tartományokból érkező zsidó családoknál nem volt nagy a termékenység. A Cseh- és Morvaországból érkező fiatal zsidók egy része éppen azért választott új hazát, mert III. Károly 1726-ban kibocsátott rendelete az örökös tartományokban megtiltotta, hogy a zsidó családoknak egynél több tagja házasodjon vagy önálló háztartást vezessen. A 18. századi népességnövekedés a korabeli országos folyamatokkal egyezően a Völgységben sem a termékenység, hanem az erőteljes bevándorlás következménye. Az időközben mezővárossá vált Bonyhád felekezetiként deklarált, de ténylegesen gazdasági, társadalmi és politikai egyensúlyának megőrzése érdekében azonban 1799-ben egyezség születik a földesurak és a zsidó hitközség között, hogy nem adnak ki további letelepedési engedélyt. Ezzel egy homogén nyugati (német, morva) gyökerű zárt zsidó közösség jön létre Bonyhádon. Ez természetesen nem jelenti a belső (vagyoni és társadalmi) differenciáltság hiányát (néhány vagyonos kereskedő mellett hamarosan kialakul a boltosok köre a batyus, házaló, iparcikkekkel kereskedő szegény zsidók többsége, a közösség foglalkozási szempontból is viszonylat tagolt).

A bonyhádi zsidók beilleszkedését, meggyökerezését, gazdasági gyarapodását és stabilitását jól tükrözi az anyagi kultúra változása is. Ezek között szembetűnő a közösségi terek bővülése 
(zsinagóga építése, kórház, szeretetház, halottas ház, a Chevra Kadisa impozáns épülete, stb.), a polgárosodás külső jegyeit is mutató családi házak, a gombamód szaporodó üzletek, a társadalmi kapcsolatok presztizsmegnyilvánulásai. A bonyhádi zsidóság gazdasági erejével párhuzamosan nőtt lélekszáma is. A hitközség tagjainak száma 1820-ban volt a legnagyobb (1631 fő), később a mobilitást a zsidók számára engedélyező 1840. évi XXIX. törvény, majd a zsidók emancipációjáról rendelkező 1867. évi XVII. törvény következményeként ez a létszám stagnált és csökkenni kezdett. E folyamat hátterében a zsidók számára is megnyiló urbanizációs színterek, a polgárosodás, a modernizáció kínálta életlehetőségek álltak. Másrész fontos szerepe volt a bonyhádi zsidóközösség életében az 1868. évi zsidó hitfelekezeti kongresszusnak, amely eredményeként a bonyhádi zsidó hitközség úgy döntött, hogy a kongresszusi (neológ) irányzatot követik. Azonban 7 család úgy döntött, kitart az ortodox irányzat mellett és megalapították az ortodox hitközséget. Az országos tendenciákkal egyezően a bonyhádi nyugati típusú bevándorló zsidó közösség is távlatilag nyitott volt az emancipációs-asszimilációs folyamatok előtt. Vallási szokásaiban is javarészt a neológiára hajlott. Az ortodox irányzat követői, a bonyhádi ortodox hitközség tagjai azonban megtartották vallásukat, fenntartották, sôt új zsinagógával és rituális építményekkel bővítették a közösségi

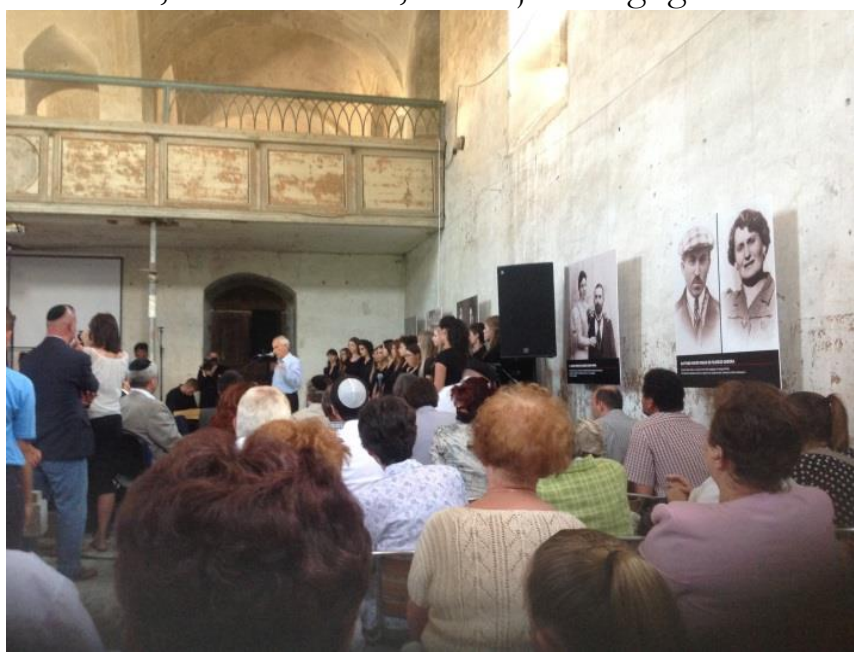
színtereket. Létszámuk a második világháborúig megtöbbszöröződöttt ${ }^{44}$, míg a neológ közösség sorra zárta be rituális épületeit, az asszimilációs folyamatban elveszítette a polgárosodás modernizációs folyamatában nemzetközi, országos vagy helyi közösségi szinten személyes karriert elérố tagjait.

7. kép: A megemlékezésre megnyitott bonyhádi neológ zsinagóga, Bonyhád, 2014. július 3. (fotó: Szabó Géza).

A fentiek tükrében felvethető az a kérdés, hogy a bonyhádi zsidóközösség a 18. század közepétől a 20. század közepéig terjedő történetéhez közelíthetünk-e az antropológia peripatetikus közösség fogalma felől? Kézenfekvőnek tűnik egy igenlő hipotézis, hiszen az adott időszakban az Aparna Rao által megfogalmazott definició valamennyi sajátos eleme érvényesül a bonyhádi zsidóközösség esetében. Egy domináns, de a városon belül határozottan korlátozott számú kisebbségről beszélhetünk (a bonyhádi zsidó hitközség tagjainak aránya a legkedvezőbb demográfiai helyzetben sem haladta meg a város lakóinak 34 \%-át). A közösség tagjai elsősorban kereskedelemmel foglalkoztak - ezzel összefüggésben megvalósult a mobilitás és a más embercsoportoktól való egzisztenciális függés követelménye - és alapvetően nem élelemtermelő vallási és etnikai egységet is képező, endogám házassági keretek között élő csoportról

\footnotetext{
44 Az ortodox hitközség az 1920-as években az alapító 7 család helyett már 100-110 családot tudhatott a tagjai között. E gyarapodás hátterében nem a neológ hitközségből való átlépés állt, hanem egyrészt a Bonyhád környéki falvak zsidó családjai, másrészt sajátos módon a továbbra is híres bonyhádi ortodox jesivába érkezô, majd a városban családot alapító nyugat-magyarországi zsidó fiatalok gyarapították a létszámot.
} 
beszélhetünk. ${ }^{45}$ A zsidó közösség Bonyhádon, a Tolna megyei Völgységben a vizsgált időszakban egy olyan sikeres kisebbségi modellt valósított meg, amelynek lényege a többségi társadalom igényeihez való alkalmazkodás révén megszerzett egzisztenciális biztonság birtokában az adott erőforrások felhasználásával a „lent’ világában a kisebbség saját normái, vallási és világi szokásrendje szerint szervezni meg a mindennapokat.

A volt Habsburg Monarchiában majd utódállamaiban a zsidó közösségek esetében a többségi társadalom igényeihez alkalmazkodó tevékenységgel történő egzisztencia teremtés a modernizáció időszakában a zsidóság felemelkedésének, emancipációjának lehetőségeit és a szinte páratlan gazdasági és szellemi fejlődés esélyét is jelentette. ${ }^{46} \mathrm{Az}$ integritás vs. integráció, a közösségi vs. egyéni stratégia kérdésében azonban nem volt megkerülhető. A bonyhádi, 1868-ban kettévált zsidó hitközség is szembetalálta magát az ortodox irányzat tradicionalista, a vallási és etnikai közösség integritását elsődlegesnek tartó valamint a neológ irányzat világiasodó, polgáriasodó, de az integráció és az asszimiláció veszélyét is magában hordozó jövőképének dilemmájával - anyagi kultúráját folyamatosan újraértelmezve a válaszlehetőségek tükrében.

\section{Felhasznált irodalom}

BLAU, Leslie: A Destroyed Community. New York 1994

BÜCHLER Sándor: A bonyhádi hitközség múltjából. Magyar Zsidó Szemle 1895, XII. 414-418.

CSISZÁr Árpád: A szatmári és beregi aprófalvak zsidósága és a falu kapcsolata a századfordulótól az 1940-es évekig. In: DEÁKY Zita - CSOMA Zsigmond - VÖRÖS Éva (szerk.): ... és hol a vidék zsidósága? Történeti és néprajzi tanulmányok a falusi, mezővárosi zsidók és nemzsidók együttéléséről. Budapest 1994, 169-186.

EGYED Antal: Bonyhád Mező-várasnak rövid leirása. In: Bonyhád a 18-20. században. Szekszárd 1975, 7-12. (Eredeti közlés: EGYED Antal: Tudományos Gyüjtemény, 1823.)

ERÉNYI Tibor: Zsidóság a Monarchiában. História 1993. http://www.tankonyvtar.hu/hu/tartalom/historia/93056/ch19.html\#id517443

EISNER János: A bonyhádi zsidók története. Tel-Aviv 1965

FARKAS JÓZSEF: Adatok a mátészalkai zsidóság életéhez, táplálkozási szokásaihoz. In: DEÁKY Zita - CSOMA Zsigmond - VÖRÖS Éva (szerk.): ... és hol a vidék zsidósága? Történeti és néprajzi tanulmányok a falusi, mezővárosi zsidók és nemzsidók együttéléséről. Budapest 1994, 131-144.

GRIESZHÁBER Endre: Majos nagyközség lakóinak lelkülete, kultúrája. In: TORKOS Veronika (szerk.): Falurajzok 1935. Faluszociográfiai dolgozatok a 30-as évekből. Budapest 1990, 136-140.

KOLTA László: Zsidó diákok a bonyhádi evangélikus gimnáziumban. Dunatáj 1995, XVIII:1. 73-77.

LÖWINGER István - SCHMELZER Kornél: Jelentés a dunántúli hitközségek felméréséről. In: TORONYI Zsuzsanna (szerk.): Zsidó közösségek öröksége. Magyar Zsidó Levéltári Füzetek 7. Budapest 1955, 93-113.

MCCAGG, O. William: Zsidóság a Habsburg Birodalomban (1670-1918). Budapest 1992

MoskoviTS, Cvi: Jesivák Magyarországon. Budapest 1999

NAGY Janka Teodóra: Néprajzi adatok a bonyhádi zsidóság történetéhez. Dunatáj 1995, XVIII:1. 57-61.

SCHWEITZER József - SZILÁGYI Mihály: A Tolna megyei zsidók története 1867-ig. Budapest 1982

SOLYMÁR Imre: A bonyhádi zsidóság gazdasági jelentősége századunk első felében. Dunatáj 1995, XVIII:1. 61-68.

\footnotetext{
45 Úgy vélték az 1868. évi nemzetiségi törvény megfogalmazói is, hogy a zsidóság a nagy kötőerôt jelentő vallás által meghatározott etnikai csoport. Lehetőnek tartották, hogy főleg neológ formában fenntartsa vallását, saját ulturális értékei, és ezekkel együtt asszimilálódjon a nem zsidó többségi társadalomba. Lásd ERÉNYI, Zsidóság.

${ }^{46}$ MCCAGG, Zsidóság.
} 
SoZAN, Mihael: Zsidók egy dunántúli falu közösségében. Debrecen 1984

SZABÓ László: A bonyhádi ózsinagóga rövid története. Dunatáj 1995, XVIII:1. 46-50.

SZILÁGYI Mihály: Tolna megye kereskedelme a törökök kiűzésétől 1848-ig. In: Tanulmányok Tolna megye történetéből I. Szekszárd 1968, 81-84.

SZILÁGYI Mihály: A bonyhádi kereskedők. In: Bonyhád a 18-20. században. Szekszárd 1975, 61-116.

SZILÁGYI Mihály: A bonyhádi zsidóság egyesületi élete. Dunatáj 1995, XVIII:1. 51-56.

SZŐTS Zoltán: A zsidóság a harmincas évek kisvárosi társadalmában. Dunatáj 1995, XVIII:1. 69-72. 


\section{ViHART Ágnes}

DOI: 10.15170/DIKE.2017.01.01.06

Bíró

Európa jogi szakjogász

Családjogi szakjogász

\section{Zsidó és dunai-sváb házassági szerződések a dualizmus-kori Magyarországon}

\section{Jewish and Danube Swabian Marriage Contracts in the Dualistic Era in Hungary}

The author has analyzed over 150 contracts from 1875 to 1883 on the basis of her own archives collection. The royal notary's institution, the contemporary marital property law institutions and the marriage contracts are presented in general and three contracts in detail. The author seeks to find the answer - based on the analyzed marriage contracts - whether or not parties counted to belong to a denomination or to a nationality.

Keywords: marriage contracts, royal notary, minorities

\section{Bevezető}

A jogi kultúra sajátos módon fejlődött a nemzeti öntudatra ébredt Magyarországon a polgári modernizáció korszakában: a közép-kelet-európai olvasztótégely, a Kárpát-medence területén együtt és egymás mellett élő nemzetiségek és népcsoportok saját jogi világa entitásuk részeként tetten érhető és nyomon követhető. A 19. sz. második felének beszédes kordokumentumai a királyi közjegyzők hagyatékában fellelhető okiratok, köztük a korabeli házassági szerződések.

\section{A királyi közjegyzőség Magyarországon}

Magyarországon a hiteles helyek mellett a 14. századtól, az Anjou-házi királyok uralkodása idején közjegyzők is múködtek. A 15. századra a közjegyzői okirat széles körben elterjedt. A közjegyzők az okiratokat az intézkedő nevében fogalmazták meg, aki az okiratra rátette pecsétjét, a közjegyző pedig záradékolta azt. A közjegyző egyrészt közhiteles személyként (publica persona), másrészt mint az egyházi bíróság jegyzője állított ki okiratokat. A közjegyzők elsősorban a klerikusok közül kerültek ki. Városi jegyzőként az egyházi pereket intéző szentszékekhez delegált egyházi bírák mellett és pápai követek kíséretében múködtek.

A mohácsi vész után a közjegyzőség intézménye csak az 1849 utáni, a jogfejlődés szempontjából termékeny időszakban bukkan fel újra: császári nyíltparancs terjesztette ki az 1855. évi osztrák közjegyzői rendtartás hatályát a Magyarországra 1858. február 7-én. A közjegyzői rendtartás, amely (újra) meghonosította hazánkban ezt az intézményt, szabálytartalmát tekintve részben francia hatásra vezethetők vissza. Az 1861-es Országbírói Értekezlet az osztrák közjegyzői rendtartás szabályait hatályon kívül helyezte, visszaállítva a hiteles helyek régi jogait a Magyar Királyságban, míg a Korona Mellékországaiban, így Erdélyben és Fiumében 1875. augusztus 1-jéig 
hatályban maradt. A gazdasági élet képviselőinek javaslatára azonban maga a közjegyzői intézmény jogrendünk része maradt, csak éppen hazai szabályozás következtében: az országgyúlés hosszú vitát követően, 1874-ben fogadta el közjegyzői törvényünket (1874. évi XXXV. törvénycikk). A törvényt hamarosan módosította az 1886. évi VII. tc., amely 1949-ig meghatározta a közjegyzők mûködésének kereteit hazánkban. ${ }^{1}$

A magyar királyi közjegyzőség a polgári igazságszolgáltatás rendszerének részként állami intézmény volt, de intézményi és önigazgatási autonómiával rendelkezett, és ekként a polgári jog területén a jogbiztonság letéteményese is volt. Az 1874. évi XXXV. törvénycikk részletes szabályokat tartalmazott a közjegyzőséget illetően, melyekből az alábbiakat emelem ki. A törvénycikk a királyi közjegyzői állás betöltését szigorú személyi és szakmai feltételekhez kötötte. A közjegyzőket az igazságügyi miniszter nevezte ki azzal, hogy „a kögjegyzó csak teljes korú magyar honpolgár lehet, a ki feddhetlen jellemü, csöd vagy gondnokság alatt nem áll, az állam bivatalos nyelvét teljesen birja (...), végre az ügyvédi vagy gyakorlati birói viasgálatot sikerrel letette, és a viasgálat letételét megelórón vagy követó, bár megszakitott két évi közjegyzôi gyakorlatot kimutatni képes".

A törvénycikk a közjegyzők illetékességét is szabályozta. Az illetékesség a királyi törvényszék területéhez igazodott, azzal, hogy „a felek mindazáltal bármelyik közjegyzóböz fordulhatnak és e tekintetben nincsenek kötve azon törvényszéki terület közjegyzöihez, a melyben laknak, vagy a melyben a jogügylet tárgya fekszilk". A törvénycikk a közjegyzői eljárás számos, garanciális jellegű eljárási

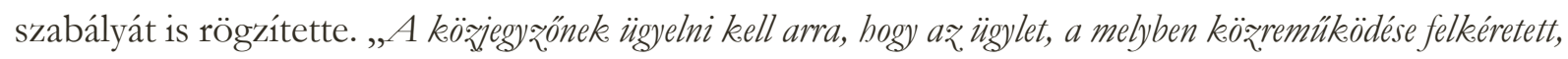
a törvénynyel ne ellenkezzék. Ez esetben erre a feleket figyelmeztetni, s ha kérelmük mellett megmaradnak, ezt a közokiratban megemliteni köteles; oly ügyletben pedig, mely a büntetö törvénynyel, a közrenddel, vagy az.

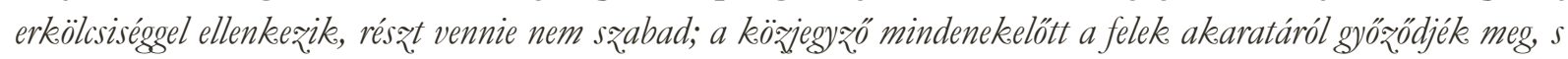
ąt világosan és határozottan foglalja irásba, az okiratot a feleknek olvassa fel s azokat felolvasása után

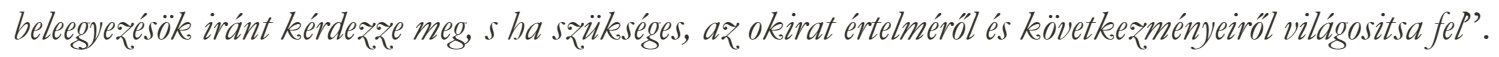

A királyi közjegyzőkrôl szóló 1874. évi XXXV. törvénycikk, majd az ezt módosító 1886. évi VII. törvénycikk felsorolta azon jogügyleteket, amelyek érvényességének feltétele a közjegyzői okiratba foglalás volt. A házassági szerződések körébe szűk értelemben a házassági vagyonjogi intézményekről szóló szerződések, tágabb értelemben pedig a házastársak egyéb jogügyletei is bele tartoztak. A közjegyző hatásköre kiterjedt a közokiratok, végrendelkezések felvételére, tanúsítványok kiállítására, okiratok és értékek őrizetére, hagyatéki ügyek körüli eljárásra, bírói megbízások teljesítésére. „Az amelyekben jogügylet érvényességébez közjegyzőoi okirat megkivántatik: a bázasfelek közti vagyoni viszonyokat szabályozó, továbbá a házastársak. közöott kötött adásvevési, csere-, életjáradéki és kölcsönszerzödéseknél, valamint egyéb jogügyleteknél, melyekben az emlitett személyek egymás irányában kötelezettséget vállalnak; ugyanazon személyek. között kötött ajándékozási szerződéseknél, ha az. ajándékozott tárgy át nem adatott; hozomány átvételéröl kiadott elismervényeknél, akár a házastárs, akár más részére adatnak ki; minden jogügyletnél, melyet vakok, olvasni nem tudó siketek, vagy irni nem tudó némák és siketnémák kötnek, ide értve az örökösödési szerzódéseket is, a mennyiben a jogügylet megkötésénél személyesen járnak el."

${ }^{1}$ Lásd bővebben RoKOLYA, A polgári közjegyzőség emlékezete 13-38. 


\section{Gánóczy Flóris hagyatéka}

A Pécsi Tudományegyetem Családjogi Szakjogász képzésén 2017. évben készített szakdolgozatomban a Magyar Nemzeti Levéltár Fejér Megyei Levéltára gyújteményéből (a továbbiakban: FML) a Gánóçy Flóris királyi közjegyző előtt 1875 - 1882 években kötött magyar nyelvű házassági szerződéseket tanulmányoztam. A dolgozat mellékletében ezeket statisztikai szempontból is feldolgoztam, lehetőség szerinti úgy, hogy az eredeti nyelvi kifejezések változatlanul maradjanak. Móron és környékén jelentős német népesség élt, akik kisebbségi kultúrájukban többek között őseik nyelvét megtartva - fontos jelentőséget tulajdonítottak a házassági szerződésnek. Így az utókorra szép számú, túlnyomó részt német nyelvű okiratot hagytak, míg a magyar nyelvű házassági szerződések a környéken a magyar és a zsidó népesség köréből kerültek ki ebben a korban.

Kisóczi és gánóczi Gánóçy Flóris királyi és udvari tanácsos, királyi közjegyző 1825. március 17én született Miskolcon. Középiskolai tanulmányait Miskolcon és Lőcsén végezte. Érettségi után elkezdte az egri papi szemináriumot, de végül az Egri Jogakadémián fejezte be tanulmányait. 1844től a Budai Helytartótanácsnál volt gyakornok. Az ügyvédi censurát 1847-ben tette le. A pozsonyi országgyűlésen báró Redl országgyűlési képviselő helyettes követeként, absentium ablegatusaként járt el. 1848. június 10-től az Igazságügyi Minisztérium segédfogalmazója volt, 1849. május 9-től a nagybányai katonai parancsnokságon hadbíró főhadnagyként teljesített szolgálatot, majd június 28tól a 95. honvédzászlóaljban harcolt századosi rangban. A Budapesti Közlöny 1891-ben megjelent 252. száma Gánóczyról megjegyezte, hogy a benne buzgó hazafi nem engedte, hogy az igazságügyi minisztériumbeli állását elfoglalja, hanem inkább honvédnak állt. A szabadságharcot végigharcolta, majd mint Dom Miguel százados és zászlóalj parancsnok kapitulált Nagyváradon.

A szabadságharc leverése után átmenetileg bujdosásra kényszerült. A magyar alkotmányosság részleges helyreállítása után, 1861-ben Pest-Pilis-Solt vármegye tiszti ügyészévé választották. 1867-ben a Pesti Királyi Törvényszék bírójának nevezték ki, ahonnan az alföldi betyárvilág felszámolása érdekében gróf Ráday Gedeon kormánybiztos mellé a Szegedi Királyi Törvényszékre helyezték. Királyi közjegyzőnek Mórra 1875. augusztus 1-jén nevezték ki. Rövidesen azonban Székesfehérvárra helyezték, ahol 1882. augusztus 1-jén nyitotta meg közjegyzői irodáját a mai Vörösmarty téren, majd a Jókai utca 3. sz. alatti lakásán. Érdekesség, hogy nem messze onnan, a Jókai utca 4. sz. alatt ma is közjegyzői iroda múködik.

Gánóçy Flóris aktívan részt vett a közjegyzői rendszer felállításában. Az ebbéli, valamint a közjóért és a társadalomért kifejtett munkássága elismeréséül 1891. október 28-án királyi tanácsosi, 1912-ben udvari tanácsosi címmel tüntették ki. Tagja volt a fóvárosi 1848-as Honvéd Egyletnek is. Emellett különféle lapokba tárcacikkeket, életképeket és rövidebb elbeszéléseket is írt: 1854 és 1860 között belmunkatársa volt a Hölgyfutár folyóiratnak, 1857-59-ben ezen kívül a Nővilágba, a Szépirodalmi Közlönybe, a Vasárnapi Újságba, a Religioba, és a Katholikus Néplapba is írt G.F., n.r.- betúk és $\Delta$ [a görög Delta] nevek alatt. 1858-ban „Olaszországi képek” címmel úti élményeit a Szépirodalmi Közlönyben adta közre, míg a Napkelet címú folyóiratban - saját neve alatt - Szicília történetét jelentette meg. Vahot Imrével 1861-től a Honvédek könyvét szerkesztette, amelyekben a szabadságharc katonáinak élményeit beszélték el három kötetben. 1867-ben megnősült, Kégl Sándor fejér megyei földbirtokos leányát, Kégl Jankát vette el. 1912-ben lemondott közjegyzői állásáról. 
Gánóçyy Flóris m. kir. közjegyző életében Székesfehérváron közismert és elismert személyiség volt; „Flóris bácsiról” több alkalommal elismerően cikkezett a helyi sajtó. 1913. november 28-án Székesfehérváron hunyt el, a Szentháromság temetôben nyugszik.

\section{A vizsgált szerződések alakiságai}

A kutatásaim során közel kétszáz házassági szerződést vizsgáltam és elemeztem. Általánosságban elmondható az iratanyag alapján, hogy az idő előre haladtával a szerződések szövegét egyre szabatosabban fogalmazták meg. A lap tetején szerepelt az ügyszám, majd a „közjegyzői okirat” megnevezés. Az 1882. évtől, a közjegyző székesfehérvári működésének megkezdésétől előre nyomtatott íveken készítették el az okiratokat; ezeken az ügyszám, a közjegyző okirat megnevezés és a közjegyző neve már nyomtatásban szerepel.

Az okiratok bevezetője értelemszerūen függött attól, hogy a közjegyző elôtt az irodájában jelentek-e meg a felek vagy a közjegyző maga ment ki a helyszínre, amely lehetett községháza vagy az ügyfél háza egyaránt. Az irodában felvett okiratok bevezető szövege a következő: „Elōttem Gánóçy Flóris moóri kir. közjegyző elött alólirt helyen és idöben megjelentek (....).” Amennyiben a közjegyző az irodáján kívül járt el, ebben az esetben ezt a tényt a szerződés bevezetô részében szabatosan, a konkrét helyszín földrajzi megjelölése alapján rögzítették.

A házassági szerződésekben két szükségszerűen szerződő fél szerepelt, a mennyasszony és a vőlegény, illetve amennyiben a szerződés a házasság megkötését követően jött létre a felek között, a feleség és a férj. Az általam vizsgált okiratok vegyes képet mutatnak abban a tekintetben, hogy miként nevezik a feleket (leendő feleség/férj, mennyasszony, vőlegény, nej, hitvestárs), sőt előfordult, hogy teljesen következetlenül egy okiratban különböző megnevezéssel szerepeltek.

A vizsgált házassági szerződésekben a bevezető részben nevezték meg a feleket. Leányoknál az atya neve, a foglalkozásának megjelölése, továbbá az szerepelt, hogy hová valósi lakos. Ezeket az adatokat a vőlegény esetében is rögzítették, mint ahogy a tanúk foglalkozása és állandó lakóhelye is bekerült az okiratba. Gyakorta volt ügyleti tanú a helyi jegyző, egyéb hivatalnok, de sokszor kereskedő tanúsította a felek személyazonosságát és a jogügylet létrejöttét. Egy-egy személy többször is szerepelt szerződésekben tanúként.

A házasfeleken túl abban az esetben vettek részt egyéb személyek a házassági szerződés megkötésében, ha egyikük, másikuk avagy mindketten harmadik személlyel kötöttek valamilyen jogügyletet. Ezek a harmadik személyek szinte kivétel nélkül valamelyik vagy mindkét házasfél szülője vagy szülei voltak, akik jellemzően valamit a gyermeküknek vagy mindkét félnek juttattak., Nem egyszer tartási szerződést is belefoglaltak az adott házassági szerződésbe. Valamennyi szerződésről elmondható, hogy a közjegyző ügyleti, illetve azonossági tanúkat alkalmazott. Egy szerződő fél személyazonosságát két azonossági tanú igazolta. Általában mindkét szerződő fél tekintetében ugyanaz a két személy volt az azonossági és egyben ügyleti tanú is. Az azonossági tanúkat a közjegyzô minden esetben személyesen ismerte. Az azonossági tanúk vonatkozásában a nevükön túl a foglalkozásukat és a származási helyüket is megjelölték.

A házassági szerződés kifejezés jól láthatóan kiemelve, középen szerepelt. Amennyiben a sorok nem értek az ív széléig, úgy kihúzták az üres helyet, így utólag semmilyen módosítása nem volt eszközölhető az okiraton. Előfordult, hogy a szerződő felek a szerződés felfektetését követően 
kívántak hozzáfüzni vagy módosítani valamit az okiraton. Ennek nem volt akadálya, ezt a tényt azonban a közjegyző az okiratban rögzítette.

Az okiratok befejező fordulata jellemzően a következő volt: „Miról jelen okirat felvétetett, az. ügy egész folyama alatt folyamatosan jelen volt ügyleti tanúk elött, a feleknek. felolvastatott, s általuk akaratjukeal mindenben megegyezónek nyilvánittatott, és aláiratott." A szövegben - gyakran német nemzetiségú ügyfelekre figyelemmel - megjegyezték azt is, hogy „a feleknek felolvastatott, s német szóval is megmagyaráztatott”. Az okirat első oldalára ragasztották az okmánybélyegeket, a végén pedig feltüntetésre került a díjjegyzék. Minden esetben felmerült közjegyzői díj, írási díj és „,bélyeg” (illeték), valamint a közjegyző helyszíni eljárása esetén „távozási dị’” is felszámításra került. A szerződéseken nagy számban maradtak fenn az eredeti illetékbélyegek.

Végezetül az okirat keltezésekor a dátumot betûvel, folyó írással rögzítették. A szerződő felek, az ügyleti tanúk és az eljáró közjegyző is aláírták az okiratot, melyet a közjegyző pecsétjével látott el. Amennyiben az okirat nem egy íven szerepelt, úgy a lapokat zsinórral összefüzték és zsinórt - viaszos pecséttel vagy körcímkével - rögzítették a papírhoz. A vizsgált anyagban a későbbi keltezésú okiratoknál fordult elő gyakrabban, hogy a tipikusan nôi hozomány jegyzéket külön leltárba (Inventar) foglalták, és ez a szerződéshez csatoltan megmaradt az utókor számára.

\section{A házassági vagyonjogi intézmények gyakorisága vizsgált házassági szerződésekben}

Az általam megvizsgált házassági szerződések az 1875-1883 közötti években keletkeztek. A szerződések tartalmára nézve szignifikáns különbségek rajzolódtak ki, ahogy ezt az alábbi grafikon mutatja.

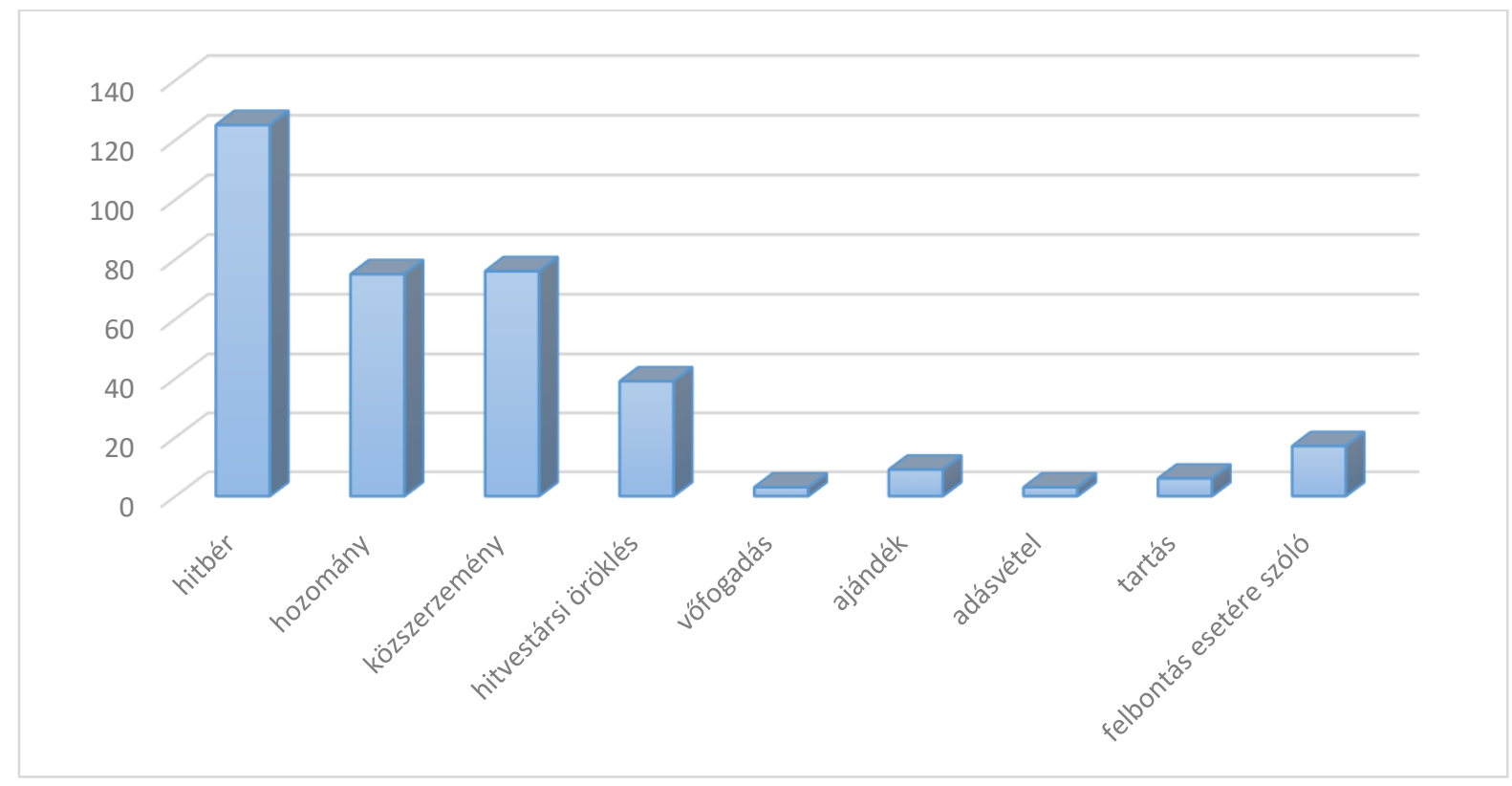

1. kép: Az egyes házassági vagyonjogi intézmények megoszlása Gánóczy Flóris közjegyzői hagyatékában szereplő házassági szerződésekben, 1875 - 1883 (forrás: a szerző összeállítása). 


\subsection{A hitbér}

A vizsgált szerződésekben szinte kivétel nélkül szerepelt a móring, amely tartalmát tekintve (általában) a magyar hitbér intézményét jelentette. ${ }^{2}$ A közjegyző előtti szerződésekben az idő előre haladtával egyre gyakrabban felváltotta a móring megnevezést a hitbér kifejezés. „A hitbér alapeszméje a magyar magánjogban a házastársi büség biztositása volt, függetlenül attól, hogy törvényes vagy irott hitbérröl volte szó. A két intézmény jogi természete megegyezett, és az irott bitbérre vonatkozó szabályok képez̧ték a bátterét a törvényes hitbérnek. (...) Nem általában véve a német dos, hanem a recepció kora elótti, germán-frank alapú dos jutott el hozzánk a 'kánonjogi házasság mindinkábbi elterjedésével és mintegy helyettesekép a nöért hajdan fizetett vételárnak.. .”3 Bár a hitbér fogalma összemosódott a móringgal és a jegyajándékkal, holott nyilvánvalóan más jogintézményekről beszélünk. A középkori szokásjognak megfelelően a törvényes hitbér mértéke a mágnásokra, a nemesekre, a polgárokra és a jobbágyokra nézve eltérően alakult a reformkori magyar jogban is (1840. évi XXII. tc.), és ez így is maradt, amíg a törvényes hitbért mint rendi intézményt 1946-ban fel nem számolták.

A szerződéses hitbérről a Magyar Jogi Lexikon a következőket jegyzi: az „irott hitbér a törvényesnek szerzódéses utánképzése. Ha nincs közelebbröl meghatározva, ugy oly ajándékot jelent a fér vagy reá való tekintettel más valaki részéról a feleség javára, mely a házasság elhálása alapján jár a bázasság megszünésekor, ha a nö a bázassági büséget meg nem szegi. Ha a feleség vagy erre való tekintettel más kötelezi a férj részére, ugy ez. viszon-hitbér, contrados. Ha hitbért jegyes vagy ágyházastársa kötelez, ugy az ügylet érvényességéhez közjegyzöi okirat kell (1886: VII. t.c₹: 22. \-a); ha más valaki igéri, ehhez irás sem kell, alakszerütlenül is érvényes."

\subsection{A hozomány}

A köznapi életben a móring, hitbér, hozomány fogalmakat részben egymással keverve használták, sőt az általam vizsgált, közjegyző - tehát jogvégzett ember - által felvett házassági szerződésekben is megfigyelhető ennek a lenyomata, nevezetesen, hogy úgy tűnik, mintha jogilag inadekvát tartalommal használnák a jogi terminus technicusokat, bár a felek szerződéses akarata, és a konkrét szerződési szöveg egymásnak való megfelelése közel 150 év távlatából már nem pontosan rekonstruálható. A móring alatt ugyan általában a hitbért értették, nemegyszer a hozományt nevezték így. ${ }^{6}$

A „hozomány (...) azon vagyontárgyak összege, amelyeket a nö $v$. erre való tekintettel más valaki, a bázasélet terbeineke (onera matrimonii) fedezése czéljából a férjnek átad. I. A súlypont az átadásban fekszik; nem belyes, mint sokan mondják, bogy a hozomány az, amit a nö férje bázához visz. Ez részint sqǚk, részint tág meghatározás; sұük, mert nem minden hozomány az, amit a nö a bázba boz: A nö vagyona (amennyiben ö adja a bozományt) két részre különül: 1. hozománymentes (szabad) vagyonára, 2. a bozományra; az elóbbi csak. tényleges, nem jogi értelemben vett hozomány (= a házba hoz). Nem is minden, a férjnek egyszerüen átadott vagyontárgy bozomány; hanem szüleséges, hogy az, hozományul adassék át. Hozományadási kötelezettség, minö az optkv. 1220.

\footnotetext{
${ }^{2} \mathrm{~A}$ fogalmat és az intézménytörténetet lásd bővebben HERGER, A modern magyar házassági vagyonjog 253-281.

${ }^{3}$ HeRGER, A törvényes és az írott hitbér Baranyában 1848 után 139-142.

${ }^{4}$ ILLÉs, Hitbér 146.

${ }^{5}$ A fogalmat és az intézménytörténetet lásd bővebben HERGER, A modern magyar házassági vagyonjog 282-301.

${ }^{6}$ Herger, A hozomány szerepe a magyar házassági vagyonjog fejlődésében 193-203.
} 
S-ban van meghatárožva, nálunk nincs. (...) Ha a hozományt a nö adja, a vagyonnak hozományul való érvényes

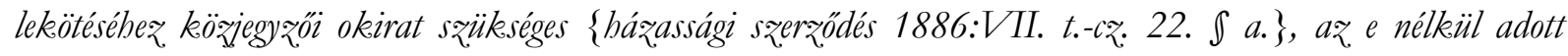
bozomány nöi szabadvagyon marad. A hozomány átadásának ill. átvételének okirati bizonyitására pedig minden esetben (akekor is, ha a hozomány mástól ered) csak közjegyzói okirattal történhetik \{u.o. 21. I a.)\}; ba a hozományt más adja, a lekötés érvényességéhez kö̈jjegyzöi okirat nem szülkséges, történhetik egész formátlanul. (...) A bozományt (ugy mint a bitbért és a jegyajándékot is) az 1840: XVI. t.-c₹. értelmében a czégjegyzékebe be lehetett

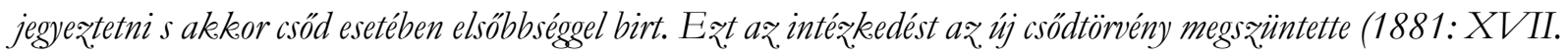
t. c₹: 267. I). (...) Fontos az az állandó gyakorlat, mely szerint a nô allaturáját a férjétöl bármikor visszakövetelhette."

A hozományt a vizsgált szerződésekben a mennyasszony vitte leendő férje házába, tekintet nélkül arra, hogy azt szülei, egyéb rokonai, ő maga vagy más adta. A hozomány tipikusan „osztrák értékben" megjelölt készpénz összegből, valamint tárgyi ingóságokból állt, de gyakori volt csak az egyik vagy csak a másik. A készpénz összege 50 Ft-tól egészen 40.000 Ft-ig terjed. A tehetősebb kereskedők, gazdák leányai általában vittek néhány ezer forint összegú készpénzt a leendő férjük házához. Az ingóságok jellemzôen bútor, ágynemű, különféle textíliák, ruha és fehérnemú, valamint ezüst holmik és ékszerek voltak. Az 1875. évtől kezdődően megfigyelhető a tendencia, mely szerint kezdetben nem volt gyakori a tárgyak tételes felsorolása, illetve ha mégis, arra csak utalás történt, de a leltárt nem füzték a szerződéshez. A szerződésekhez az 1880-as években gyakrabban csatoltak külön íven szövegezett tételes ingó vagyonleltárt.

\subsection{A közszerzemény}

A parasztság, illetve földműveléssel és alacsonyabb rendú személyes szolgálatokkal foglalkozó köznépen túl az állandósult bírói gyakorlat szerint a munkások, valamint a kereskedelmet és ipart űző személyek között is törvényes vagyonjogi rendszerként érvényesült a korlátozott vagyonközösség sajátos változata, az ún. szerzeményi vagyonközösség, azaz a feleség már a törvény erejénél fogva közkeresőnek (coacquisitrix) minősült, míg a nemesek és nemesekkel társadalmi értékelés szerint egyenlőnek tartott csoportok (ún. honoráciorok) között főszerzőnek (principalis acquisitor) a férjet tekintették, és a felek között közszerzemény csak akkor jöhetett létre, ha a felek házassági szerződésben így rendelkeztek, vagy az adott (ingó vagy ingatlan) vagyontárgyra vonatkozó visszterhes szerződésben a nőt szerzőtársként tüntették fel (Hármaskönyv, I.r. 102. c.). Az Mtj. (1928. évi magyar Magánjogi Törvényjavaslat) a rendi különbségekre, illetve társadalmi állásra nem tekintve a közszerzemény intézményét nem csak megőrizte, hanem általánossá is tette. Az Mtj. annak ellenére érvényesült a bírói gyakorlatban, hogy végül törvényként sosem fogadták el. ${ }^{8}$

A közszerzeményt a Magyar Magánjogi Lexikon hosszasan elemzi, kitérve annak eredetére is. Ennek alapján a saját joguk megtartásának kiváltságával betelepülő, jobbára városokba költöző illetve azokat alapító német telepesek által került be a közszerzemény intézménye a magyar jogi életbe. A városi polgárságon keresztül a szokásjognak is elemévé vált a közszerzemény, így

\footnotetext{
${ }^{7}$ ILLÉs, Hozomány 248-250.

${ }^{8}$ A fogalmat és az intézménytörténetet lásd bővebben HERGER, A modern magyar házassági vagyonjog 209-253. és HERGER, A közszerzemény intézménye 557-568.
} 
Werböcaynnél már részletesen szabályozást nyert, azzal, hogy „törvényböl folyólag, mint ki nem zárható vélelem, csak a jobbáayi (és polgári) osztályban kötött házasságoknál van közszeržemény". A közszerzemény intézménye előbb örökösödési igényként jelent meg, majd az 1840. évi VIII. törvénycikk 8. \$-a már akként fogalmaz, hogy „a bázasság alatti közszerzemények a jobbágyak között mindenik házastársat

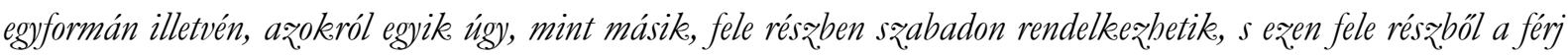
feleségét végrendelet által sem zárhatja ki; ha pedig egyik. házastársa mag nélkül és végrendelet nélkül hal meg, minden közszerzemény az életben maradott házastársra száll."

Az általam feldolgozott házassági szerződések között az első olyan, melyben szerzeményi vagyonközösségi rendszert (azaz a közszerzemény intézményét) alkalmazták, 1876-ben keletkezett. Közszerzemény alatt a felek jellemzően a házasság tartama alatt egyikük vagy másikuk által szerzett vagyont értették, ahogy az törvényes vagyonjogi intézményként érvényesült. Előfordultak azonban olyan szerződések, melyekben ehhez az általános tartalomhoz képest a felek kiterjesztették a szerzeményi vagyonközösséget egyéb vagyontárgyakra is. Tapasztalatom szerint az idő előre haladtával egyre gyakrabban fordult elő az, hogy a szerzeményi vagyonközösségi rendszert (azaz a közszerzemény intézményét) kötötték ki maguk között a felek annak ellenére is, hogy társadalmi állásuknál fogva nem feltétlenül ez lett volna irányadó.

\subsection{Az egyéb szerződésben szereplő jogintézmények}

A hitvestársi öröklés megjelenése a vizsgált házassági szerződéseknél értelemszerűen a közszerzemény intézményével párhuzamosan történik. A vizsgált szerződéseket az jellemzi, hogy amennyiben a házasfelek a házasság tartama alatt szerzett vagyont közszerzeménynek rendelik, egyúttal abban egymást kölcsönösen örökösnek is nyilvánítják, többnyire gyermektelenségük esetére, de előfordul, hogy attól függetlenül is. Mindez azért érdekes, mert a közszerzeményi rész hitvestársi öröklése törvényes leszármazó hiányában egyébként a törvényes öröklési jog része volt. A vizsgált szerződésekben nem elsősorban a hitvestársi öröklés jelenléte a különös tehát, hanem az, hogy ezt nagy gyakorisággal akkor is kikötötték, ha volt törvényes örökös. Az ilyen halál esetére szóló rendelkezéseket tartalmazó házassági szerződéseknél gyakran csupán alapos elemzés és az egyes szerződéses rendelkezések egybevetése után lehet állást foglalni abban a kérdésben, hogy a házasfelek szerződéses akarata valójában csupán a (törvényes) hitvestársi öröklés szerződéses megerősítésének vagy végrendeleti rendelkezésnek minősül-e. Előfordult olyan szerződés is, amelyben az egyik házasfél a másikat teljes vagyonára nézve örökösnek nyilvánította, és a vizsgált szerződésekben egyre gyakrabban történt a túlélő házasfél javára holtig tartó haszonélvezet alapítása is anélkül, hogy az özvegyi jogot, mint jogintézményt (ius viduale) megemlítették volna.

A vőfogadás intézménye ${ }^{10}$ különleges szerepet töltött be azon családoknál, amelyeknél férfi leszármazó nem lévén a leánygyermek férje, a vô jelentette a biztos férfi kezet a gazdaság irányítására, az abban való munka végzésére. Ugyan több olyan okiratot is olvastam, amelyben a leánygyermek férje akár a leány apjával közösen fog gazdálkodni, és ezért akár „szolgabért” is

\footnotetext{
${ }^{9}$ KOLOSVÁRY, Közszerzemény 187.

${ }^{10}$ HerGER, A közszerzemény megosztása a paraszti népréteg körében 69-70.
} 
fizetett az apa, azonban arra is találtam szép példát, hogy a vagyonkezelés jogát adta át az atya a vőnek csak.

A jegyajándékon túl is történtek ajándékozások, melyre ingatlan esetében tipikusan a tulajdonjog átruházás mellett a holtig tartó haszonélvezeti jog fenntartásával került sor. A vizsgált szerződésekben ingóság ajándékozására is van példa, az üzleti tevékenység folytatásához adott ajándékot a mennyasszony a vőlegénynek.

A vizsgált szerződésekben főképpen az ingatlanok tulajdonjogának átruházása körében találtam ellenérték melletti tulajdonjog átadást a szülők részéről az ifjú házasoknak; egy összegben, részletekben, akár a szülők, akár a testvérek felé meghatározott fizetési kötelezettséggel.

A tartási szerződések, illetve részben tartási jellegú jogügyletek sem voltak ritkák a feldolgozott szerződések között. A generációk együtt élésének és közös gazdálkodásának szerződésbe fektetésére is találtam példát.

A kötelező polgári házasságkötést bevezető törvény (1894. évi XXXI. tc.) megszületése előtti időben a felekezeti hovatartozástól függött, hogy volt-e lehetőség a házasság felbontására. A katolikus vallás szerint a házassági kötelék szentségként felbonthatatlan volt, így náluk eleve csupán a separatio a thoro et mensa, azaz az ágytól és asztaltól való elválasztás jöhetett szóba. Az egyéb felekezeteknél azonban lehetőség nyilott a házassági kötelék felbontására is.

A vizsgált szerződések között meglehetősen sok olyan szerződés volt, amelyben a felek válás esetére is rendezték vagyoni viszonyaikat, mégpedig általában akként, hogy meghatározták a visszaadásra kerülő vagyontárgyak körét, a válóper tartamára az ideiglenes nőtartás mértékét és akár további, a felek által lényegesnek ítélt kérdéseket is.

\section{Müller Antal moóri lakos kötélgyártó és Kolb Julianna moóri lakos házassági szerződése}

Az első bemutatásra kerülő jogügyletet 1880. május 2-én kötötték 54/1880. sz. alatt Gánóczy Flóris királyi közjegyző előtt Móron. A szerződés bevezető részében megjelölték a feleket. A vőlegény Müller Antal, foglalkozására nézve kötélgyártó, tehát iparos; a mennyasszony pedig Kolb Julianna, aki Kolb Károly móri mészáros lánya, szintén az iparos-kereskedő rétegbe tartozik. A két ügyleti tanú Mayer Antal építész és Répásy Mihály kalapos volt.

A szerződéssel a vőlegény „móringolta” a kötélgyártói üzletét minden ehhez tartozó szerszámmal és felszereléssel együtt, teljes tulajdoni joggal a leendő feleségére. A vonatkozó értelmező és egyéb lexikonok a korban szinte egyöntetűen a fentiekben már említett Morgengabe intézményével vagy egyszerủen a jegyajándékkal azonosították a magyarosított móring kifejezést, azonban ez ebben a formában - tekintve az általam feldolgozott házassági szerződéseket - nem helytálló, mivel a tényleges tartalmat tekintve a móring itt a magyar hitbérnek felelt meg.

A vizsgált iratanyagban 1881. évtől kezdődően több alkalommal az ígért juttatást egyébként kifejezetten hitbérnek nevezte az okirat, azt megelőzően azonban csak a „móringol” kifejezés lelhető fel a szerződésekben. A vizsgált szerződések alapján egyértelmú, hogy a házasfelek a móringot a gyermektelen („,magtalan”) elhalálozás esetére ígérték a túlélő házastársnak. A vizsgált Mór környéki házassági szerződéseket a kölcsönös ígéret (hitbér és viszonthitbér) jellemezte. 


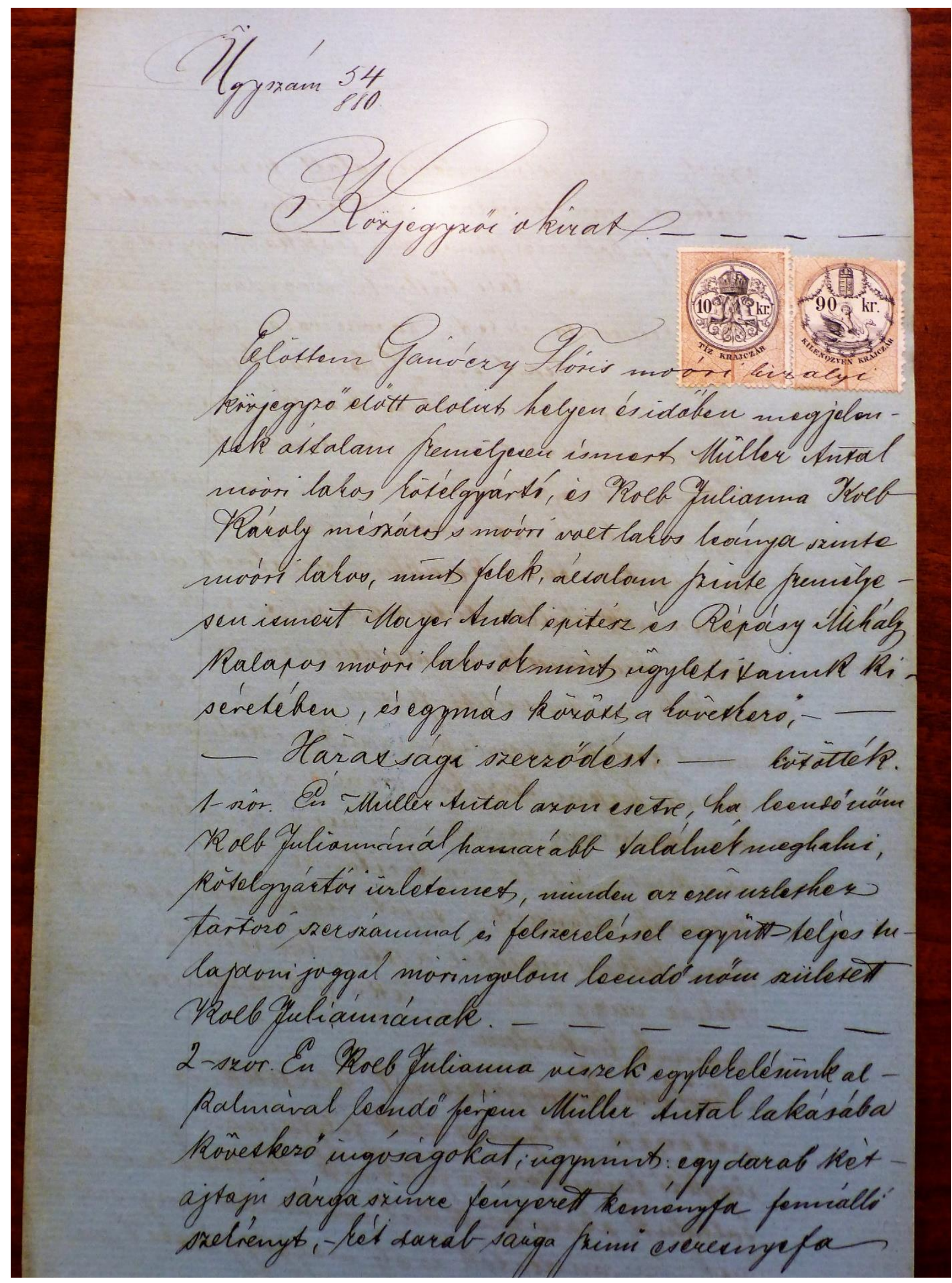

1. kép: Müller Antal és Kolb Julianna házassági szerződése, 1. oldal. Mór, 1880. május 2. FML VII.151.54/1880. sz. 


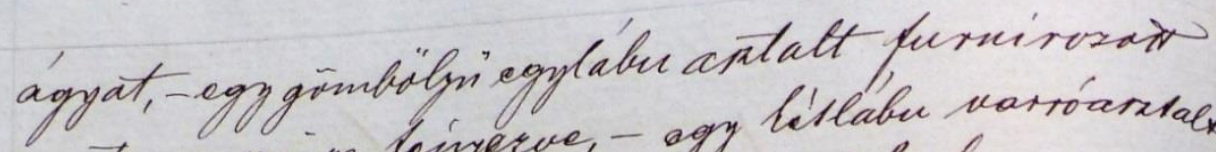
gestenge sxinre feingerve, - ogy h'slabu varróaralak

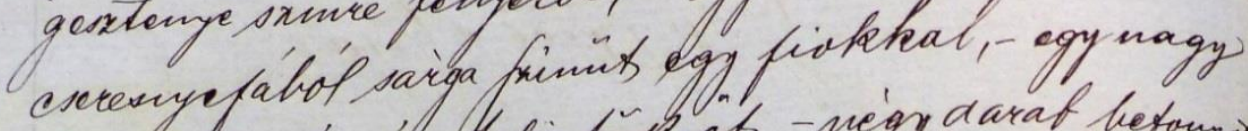

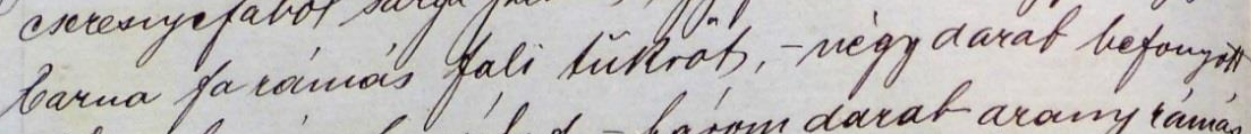
telete lemengfa siehes, - havom darat arany támás

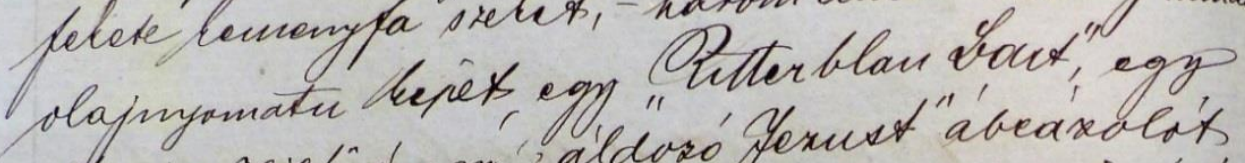

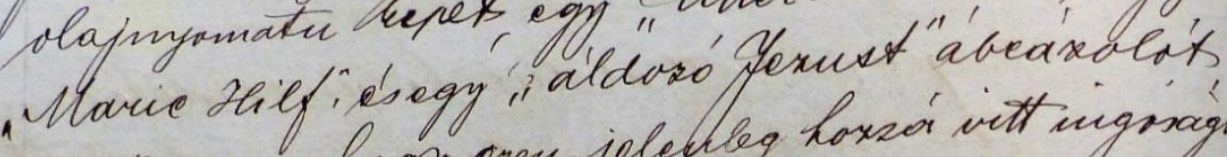

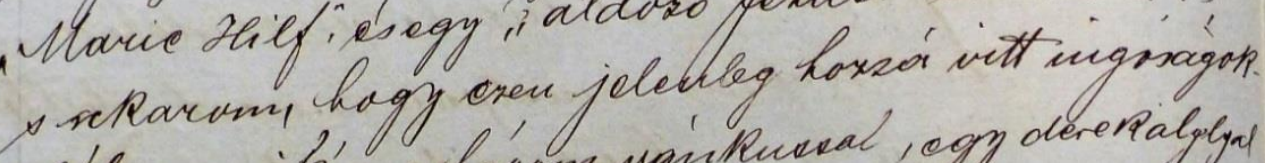

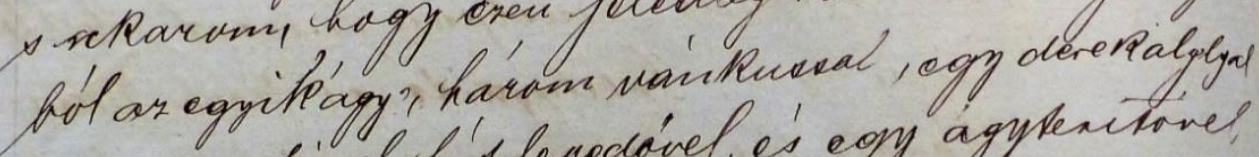

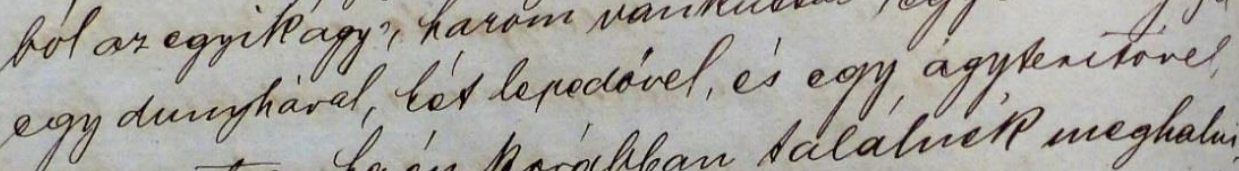
qran cxetre, ha én horoblean salabietp neghahi

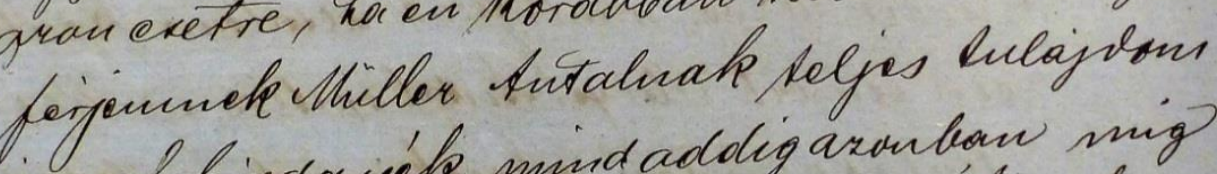
jogoal liocdocisét, mind addigarmbow mig on clate mind a peuteft felsoralt ingosay abra, mind pedig ar eqpbekelís unte alpalmaval míg bondo"ferjen harahor viendo" op pres aigy, es feheir maminume noveretesen: noopy dungharas hat

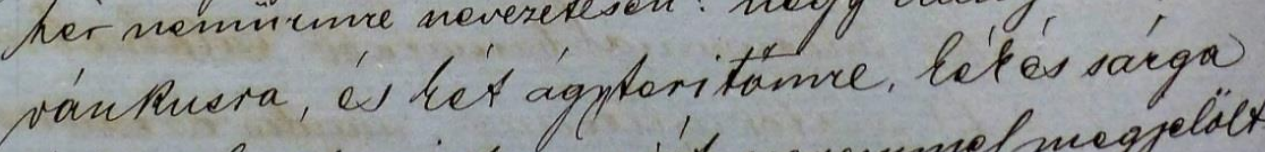
frimel, valauins a saját nevenumel megjelös

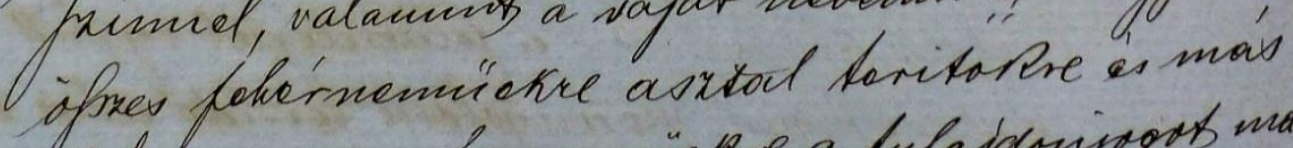

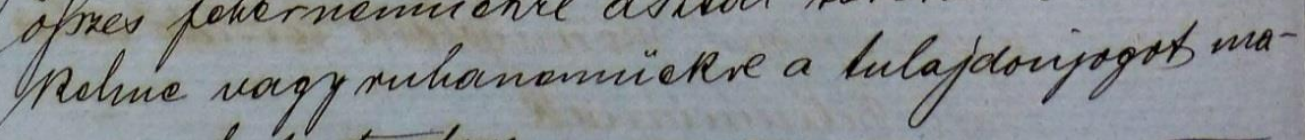

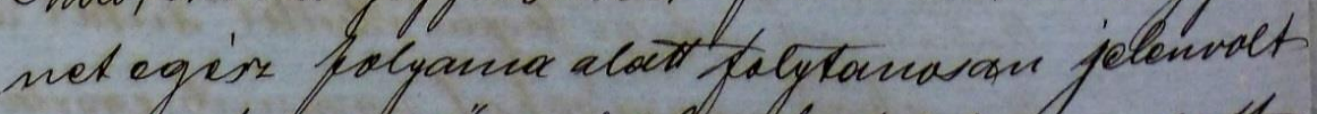

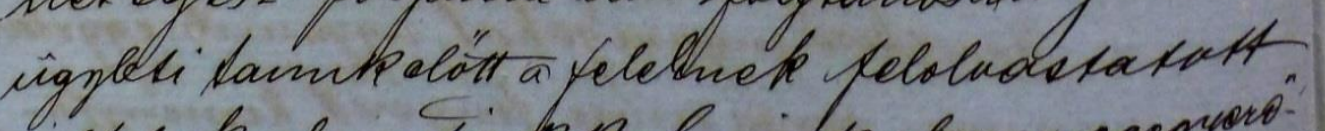
saltaluk alearatjuthral imidenben megegyor -

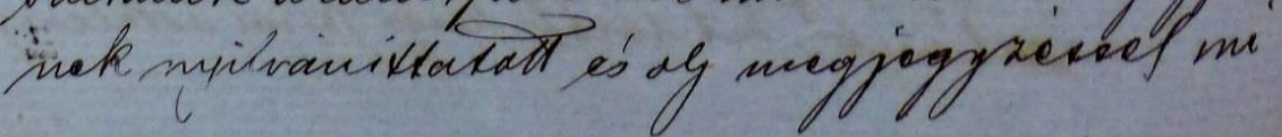

2. kép: Müller Antal és Kolb Julianna házassági szerződése, 2. oldal. Mór, 1880. május 2. FML VII.151.54/1880. sz. 


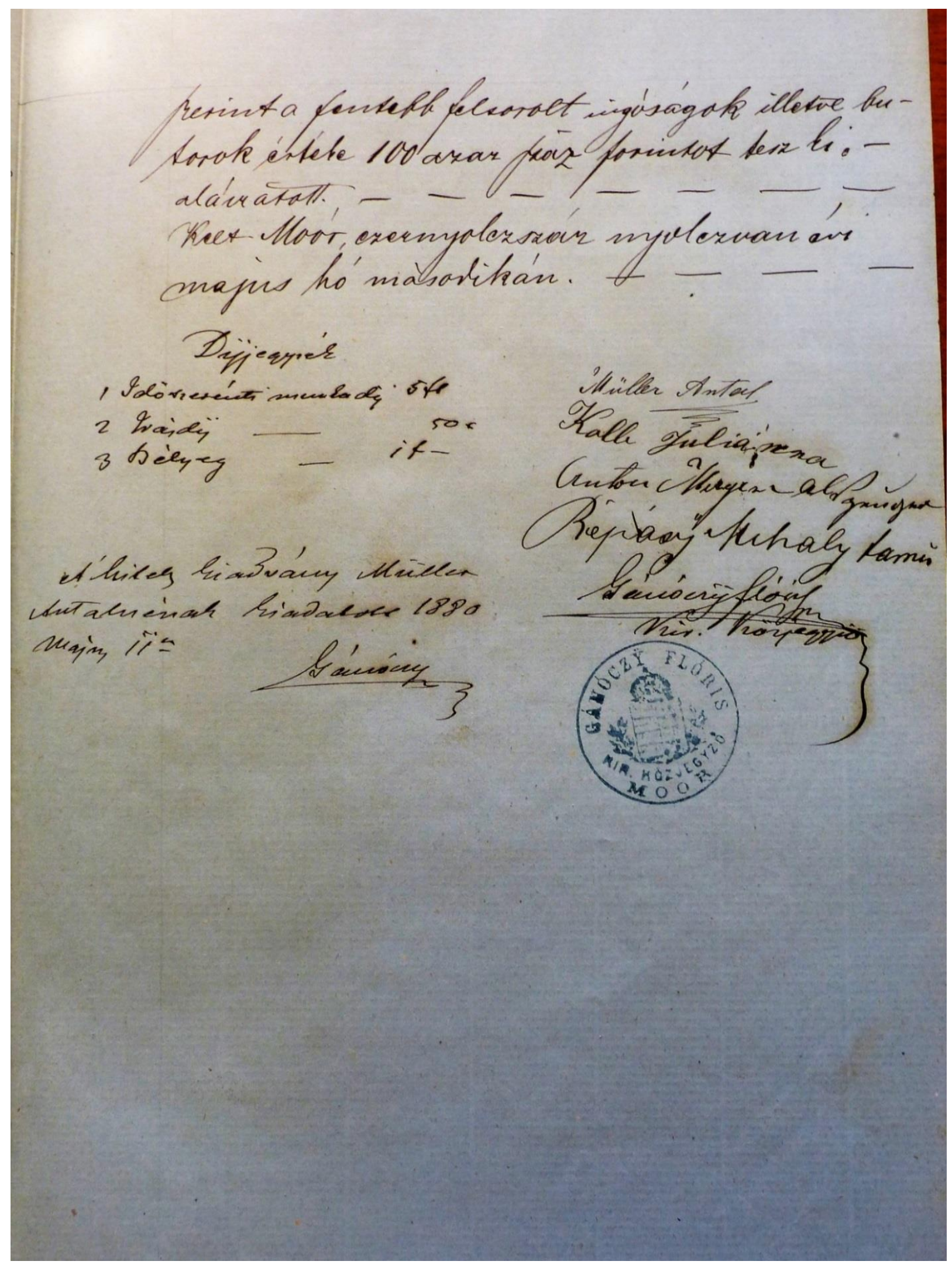

3. kép: Müller Antal és Kolb Julianna házassági szerződése, 3. oldal. Mór, 1880. május 2. FML VII.151.54/1880. sz 
A móring jellemzően készpénz összeg volt. A feleség a férjnek szokásosan a neki ígért hitbér felét ígérte. A móring összegénél sokszor különbséget tettek aszerint, hogy egy vagy két év házasság után halt meg a férj vagy a feleség, és értelemszerūen a hosszabb idő eltelte után járt a magasabb összeg. Előfordult, hogy a móringolt vagyon mértékét gyermekek születésétől tették függővé. A szerényebb anyagi körülmények között élő házasulóknál gyakran megesett, hogy nem vagy csak minimális összegű pénzt ígért a mennyasszony a vőlegénynek, hanem egy „katonaágyat”, és tételesen feltüntették, hogy ez miből tevődött össze. A szerződések zöménél a mennyasszony által a vőlegénynek móringolt vagyont a hozományból emelték ki, azaz egy részét a feleség magtalan halála esetére megtarthatta az özvegy férj, a többi része azonban visszajárt az elhunyt feleség családjának.

A szerződésben tételesen felsorolták a mennyasszony hozományát, amelynek - nagyon fontos és tipikusan magyar - jogi jellemzője, hogy szabadvagyon-jellege megmaradt. Ebből a hozományból emelték ki a mennyasszony részéről a leendő férjének hitbérként rendelt, azaz móringolt vagyont. A hozomány tárgyaiból a vizsgált szerződésben sejthető, hogy német nemzetiségű és katolikus vallású a mennyasszony, mivel egy „Marie Hilf” és egy „áldozó Jézust” ábrázoló arany rámás olajnyomatú kép is szerepel köztük. A szerződés végén található a díjjegyzék - az „időszerinti” munkadíj, az írásdíj és a bélyeg - valamint a folyó írással felvett keltezés. A felek és a tanúk aláírását követi utolsóként a közjegyző aláirása.

\section{Ifjabb Takács János tabajdi lakos földtulajdonos és neje, született Nagy Lidia házassági szerződése}

Az alábbi szerződést Gánóczy Flóris közjegyző 50/1878. sz. alatt vette fel Tabajdon, 1878. május 16án. A szerződés ügyleti tanúi Ballay Sámuel községi jegyző és Pék György községi segédjegyző voltak. Ez a szerződés abban különbözött a többitől, hogy a házasfeleken - ifjabb Takács Jánoson és Nagy Lidián kívül - más személyek is szerződő félként szerepeltek benne: a férj szülei, öreg Takács János földtulajdonos és neje, született Sáska Erassébet, valamint a mennyasszony édesapja, Nagy István tabajdi lakos földtulajdonos.

A férj szülei átadták a tabajdi 23. sz. telekjegyzőkönyvbe foglalt 1-18. sz. 1/4 kültelket (legelővel és réttel) a haszonélvezet fenntartásával, örökségi osztályba betudással. Ezen kívül a férj magtalansága esetére móringolt a feleségének 400 forintot. A feleség apja akként vett részt a szerződésben, hogy ő adja a hitbért a férjnek: ha gyermektelenül 3 éven belül halna meg, 300 forintot, ha azon túl, évenként 20 forint szolgabért kötelez és egy teljesen felszerelt katonaágyat. 


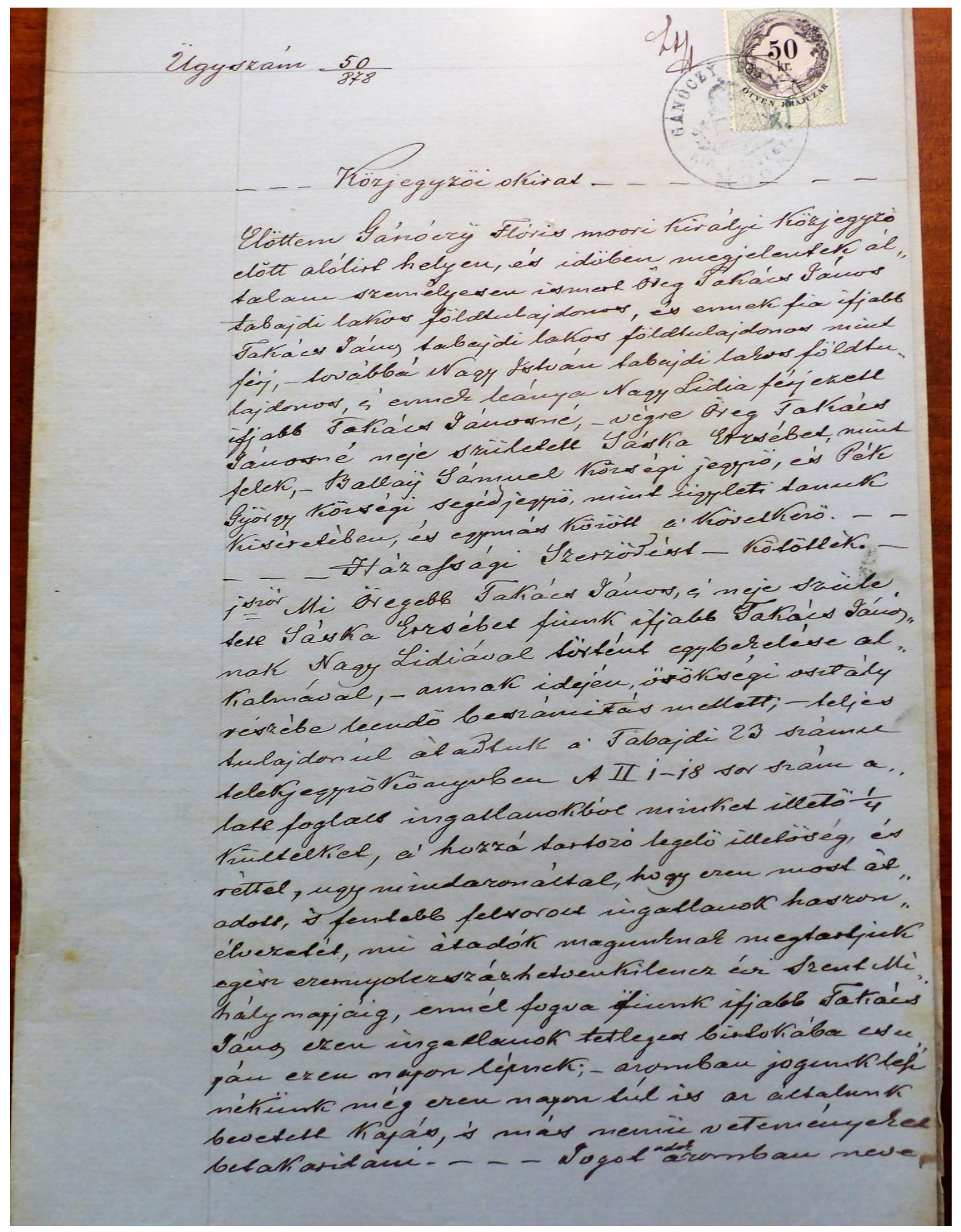

4. kép: Ifjabb Takács János és Nagy Lidia házassági szerződése, 1. o. Tabajd, 1878. május 16. FML VII.151.50/1878. sz. 


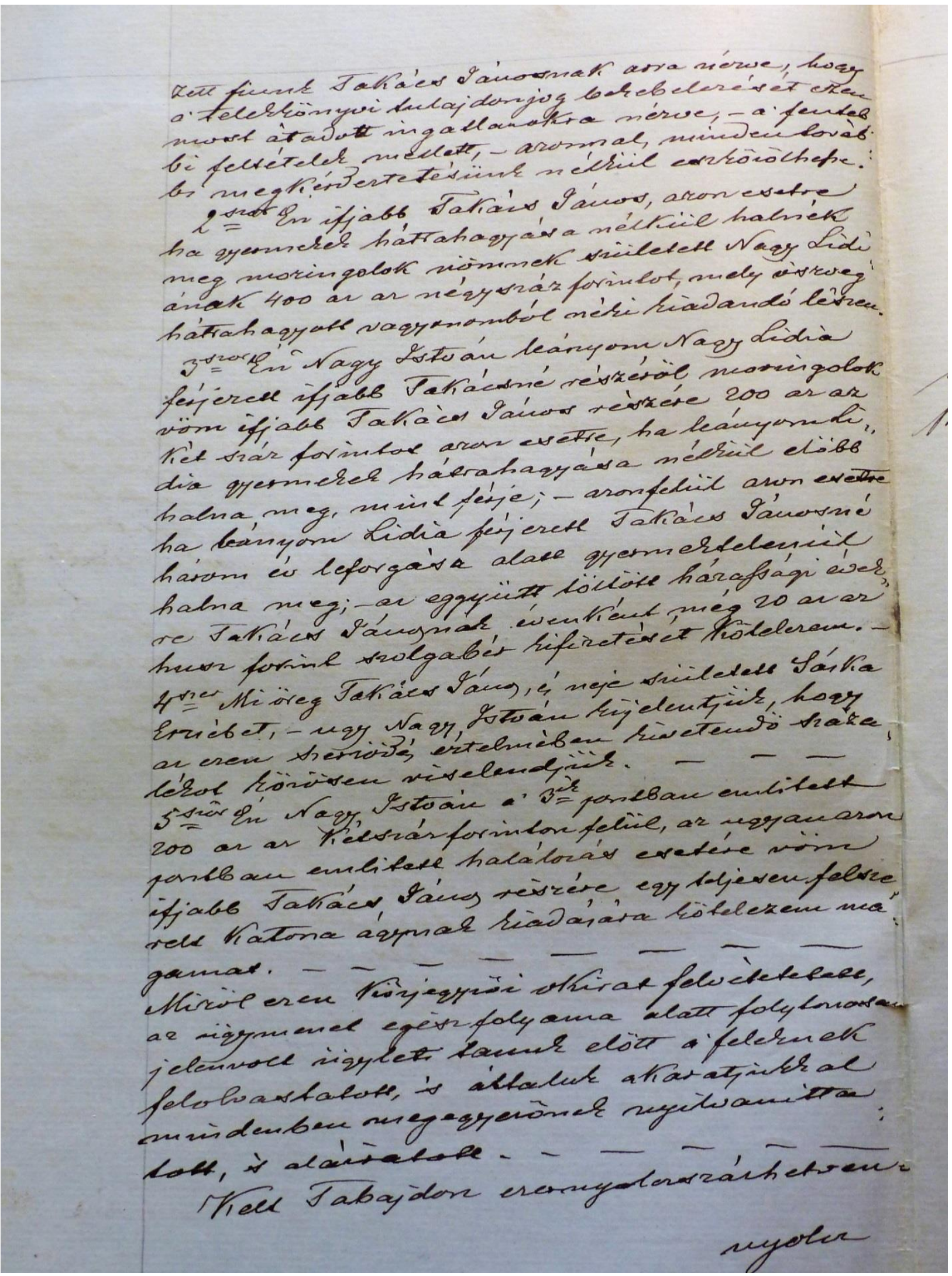

5. kép: Ifjabb Takács János és Nagy Lidia házassági szerződése, 2. o. Tabajd, 1878. május 16. FML VII.151.50/1878. sz. 


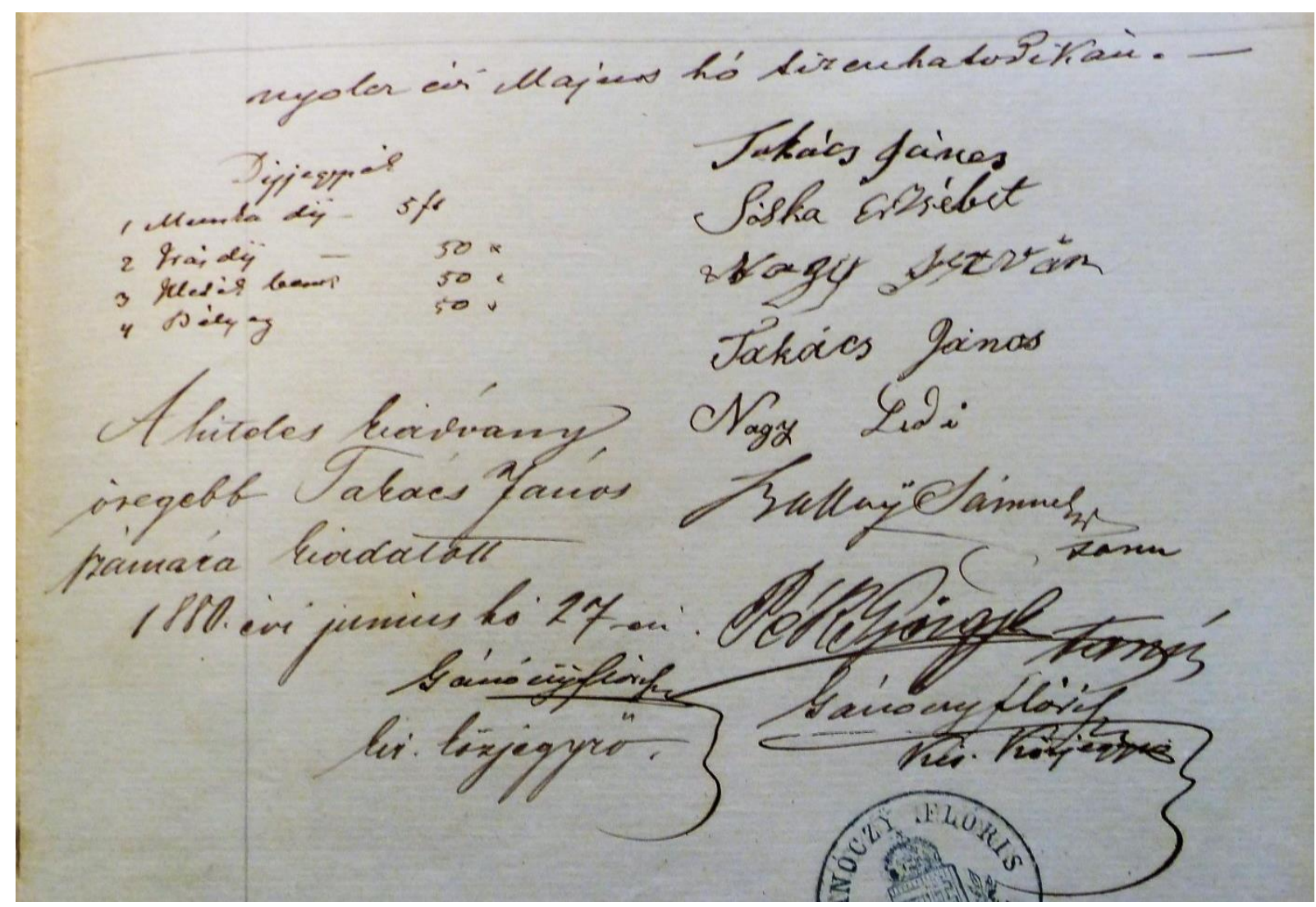

6. ábra: Ifjabb Takács János és Nagy Lidia házassági szerződése, 3. o. Tabajd, 1878. május 16. FML VII.151.50/1878. sz.

\section{Grünfeld Antal ösküi lakos bérlő és Weisz Szeréna felcsúthi lakos házassági szerződése}

A 85/1883. ügyszám alatt Székesfehérváron, 1883. március 12. napján felvett házassági szerződés érdekessége abban áll, hogy vizsgált iratanyagot tekintve ebben rendelkeztek az egyik legnagyobb vagyontömegről, ennek megfelelően kellően részletes is a szerződés. A szerződés azon kevés szerződések közé tartozik, amelyben kifejezetten érvényességi feltételként szerepelt, hogy a házasulandó felek izraelita szertartás szerint kel egybe. A mennyasszony - akit a szerződésben kisasszonynak neveznek - és a vőlegény örök hűséget ígért egymásnak. Ez a fordulat ritka az általam vizsgált levéltári anyagban. A mennyasszony hozománya tetemes: 10.000 Ft készpénz és a szerződéshez külön íven csatolt leltár szerint 3.771 Ft 55 Kr értékű ingó vagyontárgyak. A leltárban külön római számozással szerepelnek a felső ruhák, a „fehér nemüek” és az ékszerek. A hozomány gazdaságba való beruházására a mennyasszony engedélyt adott leendő férjének. A hozományt ekként át is vette a leendő férj. Ha a házasság első vagy második évében a férj gyermek hátrahagyása nélkül meghalna, úgy az összes női hozomány visszaszállna a mennyasszonyra. Ezen felül „minden esetre és minden idôre" kikötött a leendő férj 5.000 forint hitbért, azzal, hogy ez hátrahagyandó vagyonából ez mindenek előtt kiadassék. Ezzel azonban minden özvegyi igényéről le kell mondania a leendő feleségnek. 


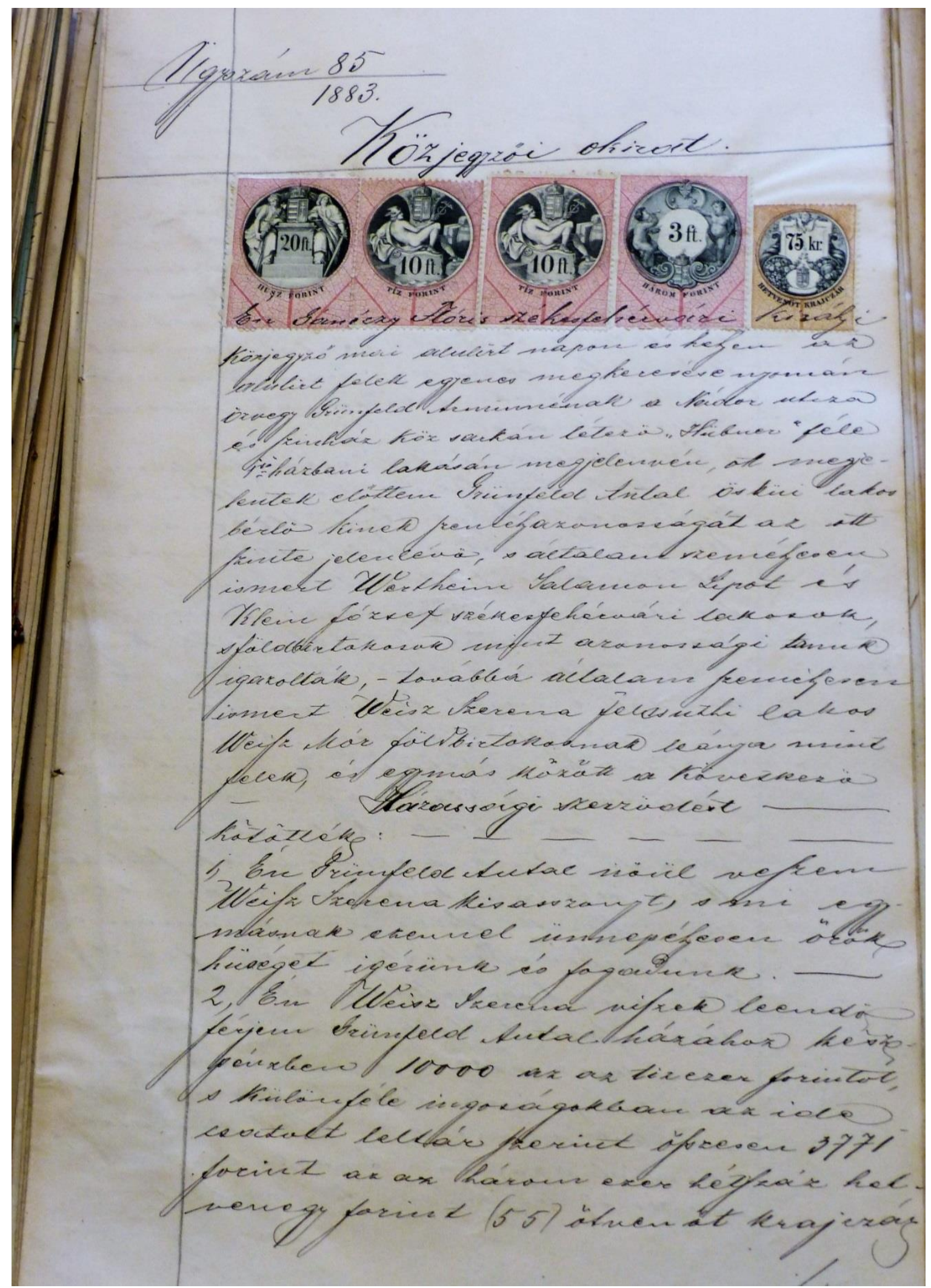

7. kép: Grünfeld Antal és Weisz Szeréna házassági szerződése, 1. o. Székesfehérvár, 1883. március 12. FML VII.151.85/1883. sz. 


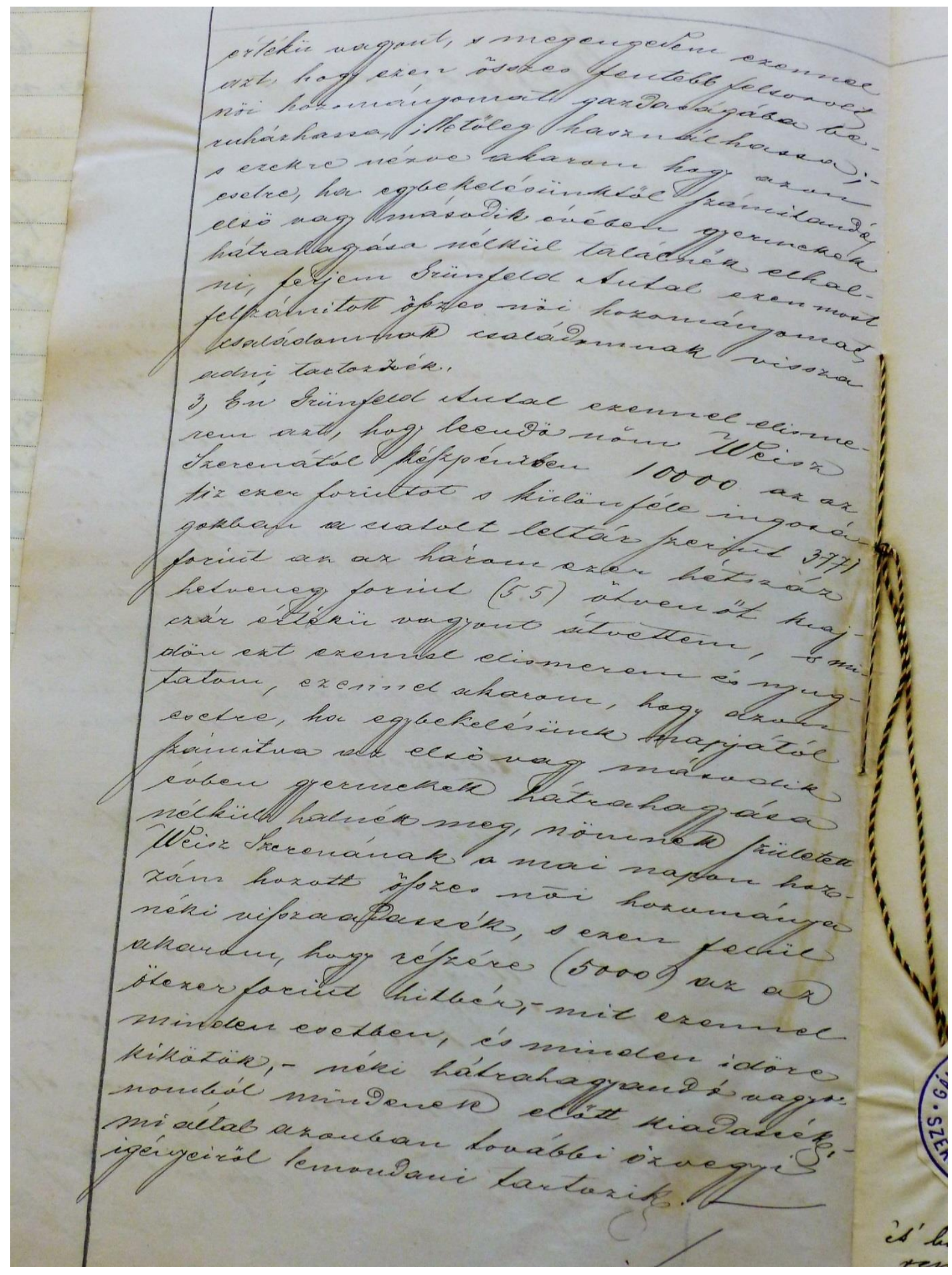

8. kép: Grünfeld Antal és Weisz. Szeréna házassági szerződése, 2. o. Székesfehérvár, 1883. március 12. FML VII.151.85/1883. sz. 


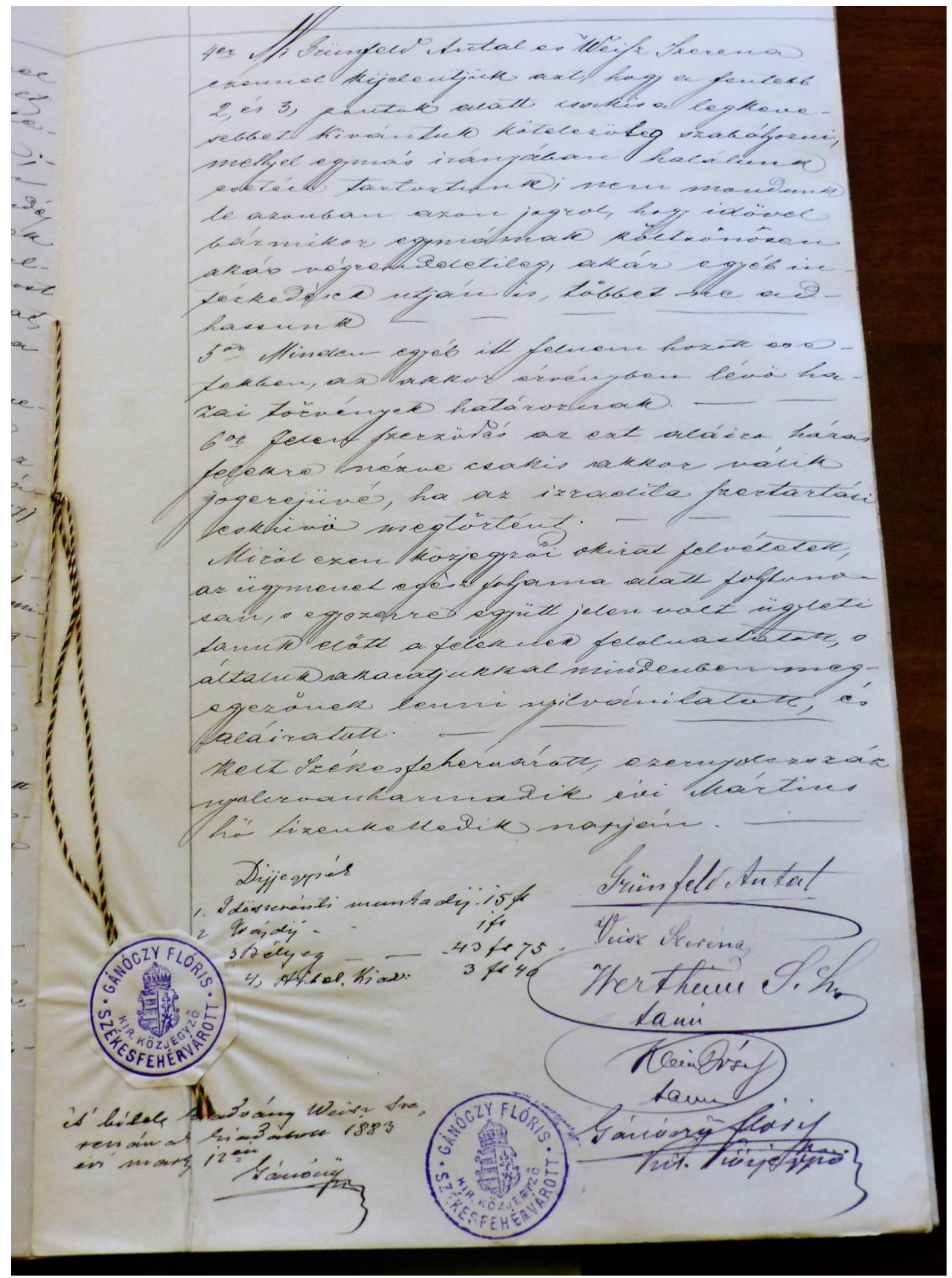

9. kép: Grünfeld Antal és Weisz Szeréna házassági szerződése, 3. o. Székesfehérvár, 1883. március 12. FML VII.151.85/1883. sz. 


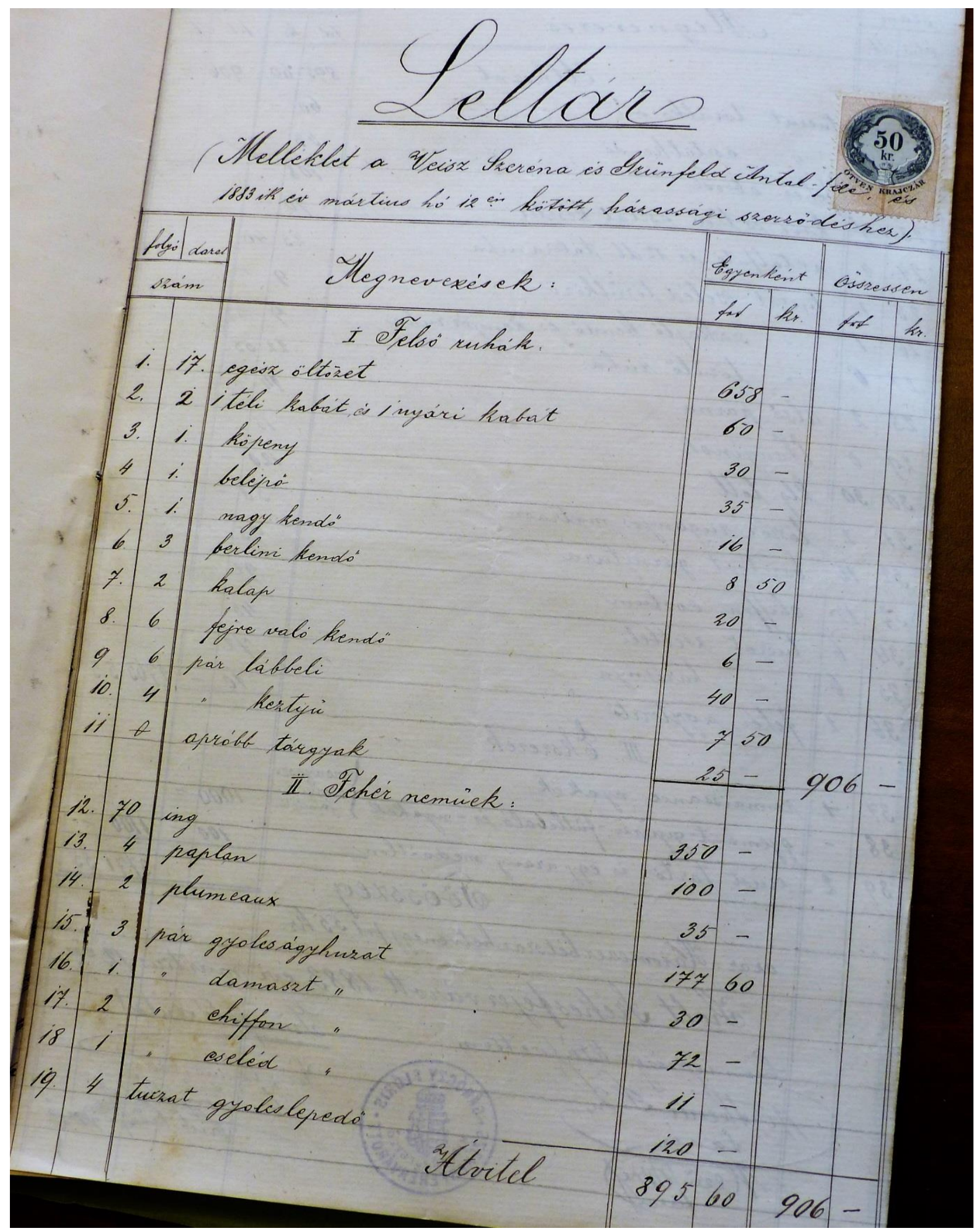

10. kép: Grünfeld Antal és Weisz Szeréna házassági szerződéséhez csatolt leltár, 1. o. Székesfehérvár, 1883. március 12. FML VII.151.85/1883. sz. 


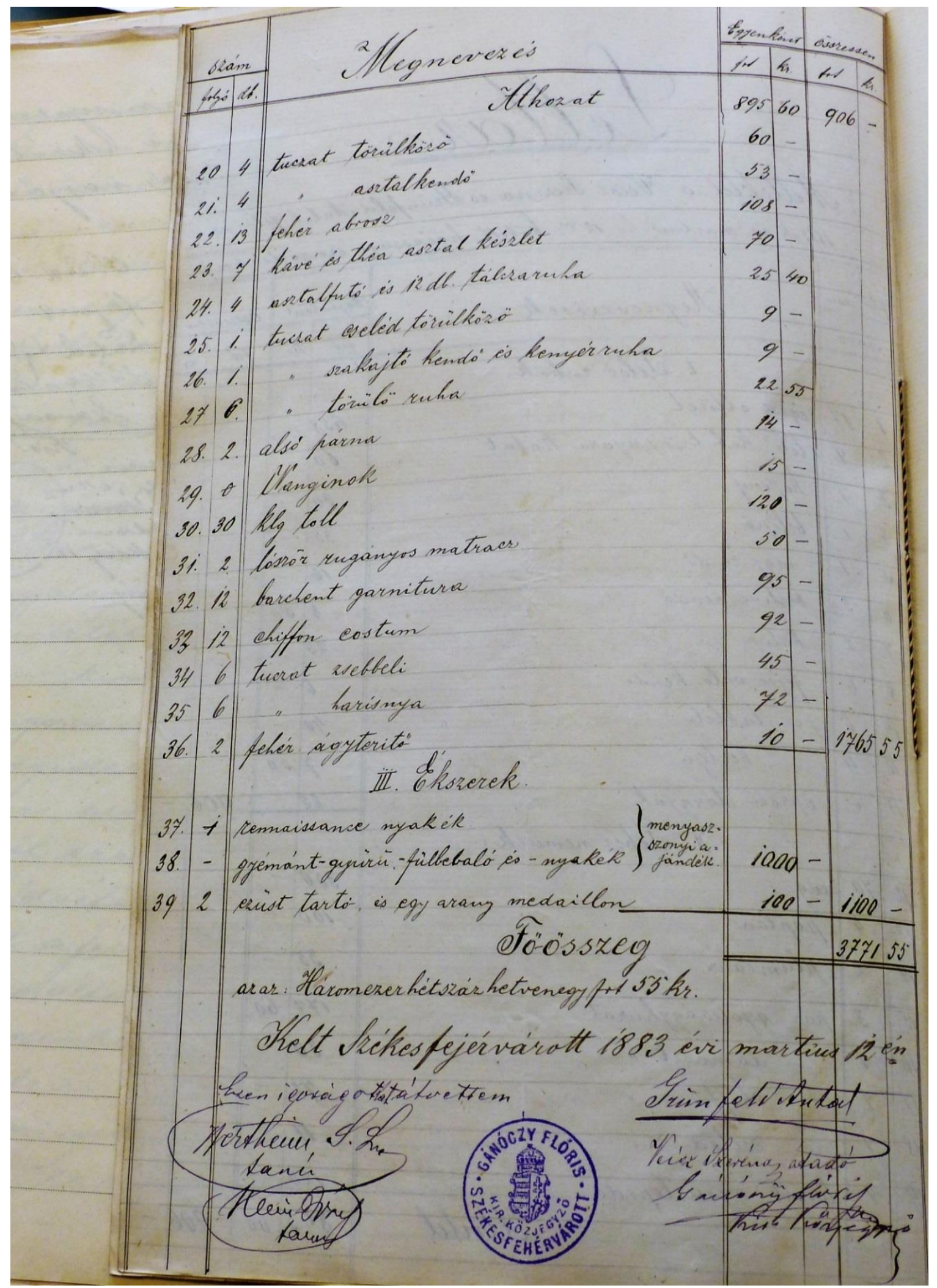

11. kép: Grünfeld Antal és Weisz. Szeréna házassági szerződéséhez csatolt leltár. Székesfehérvár, 1883. március 12. FML VII.151.85/1883. sz 


\section{Következtetések}

A vizsgált több mint 150 házassági szerződésből három szerződés segítségével 1 tettem kísérletet arra, hogy bemutassam, a magyar királyi közjegyzőség felállítását követő néhány évben milyen módon kötöttek házassági szerződéseket a korabeli Magyarországon. A közjegyzői iratanyagot áttekintve megállapítható, hogy a századfordulóhoz közeledve nőtt a házassági szerződés száma.

Egyfajta tendencia is nyomon követhetô az évek múlásával, mivel a kezdeti rövid, túlnyomó részben kizárólag a hitbért vagy a hozományt szabályozó szerződések mellett egyre gyakoribbá váltak a törvényes vagyonjogi intézményeket alakító szerződések, a női szabad vagyon biztosításáról valamint a házasság felbontásának esetéről szóló rendelkezések.

A vizsgált szerződéseket 1875-1883 években kötötték Móron, Székesfehérváron és a környező településeken, ahova korábban jelentős számú német lakosság települt be, ugyanakkor a városi iparos-kereskedő réteg is kialakult már. A szerződések tanulmányozása és összevetése során felvetődik a kérdés: van-e eltérés az egyes nemzetiségekhez, felekezetekhez, társadalmi csoportokhoz tartozó személyek házassági szerződései között?

Rögzíthető, hogy minden szerződésben a felek személyi adatának részét képezte a foglalkozásuk megjelölése. Az elemzett több mint 150 szerződés alapján megállapítható, hogy jóval gyakrabban fordul elő az iparos-kereskedő réteg tagjai közötti szerződés, mint a paraszti néprétegben. (A legfelsőbb társadalmi csoport házassági vagyonjogi kultúrájáról a vizsgált anyag alapján nem lehet képet alkotni.) Értelemszerűen a vagyonnal bírók közötti házasságkötés esetén merült fel a házasságba bevitt vagyon házassági szerződéssel történő szabályozásának gondolata. Az első szerződés az iparos réteg tipikus példája volt.

A felekezeti és a kisebbségi hovatartozás elhatárolási pontként való alkalmazása már sokkal több nehézséget jelentett. Meghatározható-e a nemzetiség vagy a felekezet anyakönyvi adatok hiányában? Többségében a szerződésben szereplők nevek nyelvi sajátosságaiból indultam ki, illetve a vallásra vonatkozó esetleges megjegyzésekből, mint például az izraelita bontójogra történt utalás vagy a leltárban felsorolt katolikus kegytárgy.

Arra a kérdésre, hogy a felekezeti hovatartozásnak van-e jelentősége a szerződés tartalmára nézve, kétarcú válasz adható. Ugyanis van is, meg végső soron nincs is. Van, mivel az izraelita vallású felek által kötött szerződésekben - a vizsgált anyagot tekintve - jellemzően több a vagyoni rendelkezés, a felek általában a kereskedő-iparos réteghez tartoznak, és ehhez kapcsolódnak az üzletükre, az abba való befektetésre vonatkozó precízebb és részletesebb rendelkezések. A földtulajdonos réteg szerződései között találjuk a legtöbb ingyenes juttatást, tartási jellegű és halál esetére szóló rendelkezést. Ugyanakkor mégsem olyan nagy a különbség: az egyes szerződések nagyon hasonlóak, mivel egységes alakiságok mellett a jellemzően a tradicionális magyar jog házassági vagyonjogi jogintézményeit (hozományt, hitbért) használták. Ennek alapján az egyes szerződések azonos (jogi) alapon épülve váltak - a nemzetiségi, felekezeti hovatartozás sajátos szokásai mentén - egyedivé.

A 19. század utolsó negyedének házassági vagyonjogáról semmi pontosabb képet nem adhat, mint maguk a házassági szerződések, hiszen ezekben közvetlenül maga az élő jog testesült meg. Az 
akkor még kodifikálatlan, tradicionális magyar házassági vagyonjog intézményei pedig a szerződésekben a szerződéses szabadsággal találkoztak, és így váltak változatossá.

\section{Felhasznált források és irodalom}

1622. évi LXVII. törvénycikk hitbéres özvegyekről szóló 618-ik évi 61-ik törvénycikkelyek megújitása és megmagyarázása

1840. évi VIII. törvénycikk a jobbágyok örökösödéséről

1874. évi XXXV. törvénycikk a magyar királyi közjegyzőkről

1894. évi XXXI. törvénycikk a házassági jogról

WerbőCZY István Hármaskönyve. In: MÁRKus Dezső (szerk.): Magyar Törvénytár 1000 - 1895 Millenniumi Emlékkiadás. Budapest 1897

ÉRDÚJHELYI Menyhért: A közjegyzőség és hiteles helyek története Magyarországon. Budapest 1899

HERGER Csabáné: A hozomány szerepe a magyar házassági vagyonjog fejlődésében. Jogtudományi Közlöny 2016/4.

HERGER Csabáné: A közszerzemény intézménye a 19-21. századi magyar házassági vagyonjogban. Jogtudományi Közlöny 2014/12.

HERGER Csabáné: A közszerzemény megosztása a paraszti népréteg körében Baranyában 1848 után. In: VARGA Norbert (szerk.): VI. Szegedi Jogtörténeti Napok báró Eötvös József születésének 200. évfordulója alkalmából. Szeged 2014, 67-95.

HERGER Csabáné: A nővételtől az állami anyakönyvvezetőig. A magyar házassági köteléki jog és az európai modellek. Budapest - Pécs 2006

HERGER Csabáné: A törvényes és az írott hitbér Baranyában 1848 után. In: NAGY Janka Teodóra (szerk.): Szokásjog és jogszokás. Pécs 2016, 139-164.

HeRGER Csabáné: Házassági szerződések Baranyában 1848 után. In: BALOGH Elemér - HoMOKI-NAGY Mária (szerk.): Három szegedi jogtörténész: Tudományos emlékülés Bónis György születésének 100., Both Ödön születésének 90., és Iványi Béla halálának 50. évfordulóján. Szeged 2017, 170-186.

HERGER Csabáné: A modern magyar házassági vagyonjog kialakulása és rendszere a német jogfejlődés tükrében. Passau 2017

ILLÉS József: Hitbér. In: MÁRKus Dezső (szerk.): Magyar Jogi Lexikon IV. Budapest 1903, $244-247$.

ILLÉS József: Hozomány. In: MÁRKuS Dezső (szerk.): Magyar Jogi Lexikon IV. Budapest 1903, 248-250.

JANCSÓ György: A magyar házassági és házastársi öröklési jog. Budapest 1901

KOLOSVÁRY Bálint: Közszerzemény. In: MÁRKus Dezső (szerk.): Magyar Jogi Lexikon V. Budapest 1904, $186-191$.

MÁNDOKI László: A mohácsi reformátusok házassági szerződései (1790-1827). Janus Pannonius Múzeum Évkönyve (1964), Pécs 1965

ROKOLYA Gábor: A polgári közjegyzőség emlékezete. Budapest 2009

SZINYEI József: Magyar írók élete és munkái. Budapesti Közlöny 1891 (http://mek.oszk.hu/03600/03630/html/g/g06329.htm, 2017.03.11.) 
RÉKASINÉ AdAMKó Adrienn

DOI: 10.15170/DIKE.2017.01.01.07

PhD-hallgató

jogi előadó

Magyar Országos Közjegyzői Kamara Jogi Iroda

\section{Aki megment egy életet: az örökbefogadás az osztrák és a magyar magánjog rendszerében a polgári korszakban}

Who save a life: Adoption in Austrian and Hungarian privat law in the bourgeois era

The main aim of this study is to introduce the reasons and conditions of the adoption, comparing the Austrian and Hungarian law. This study takes as a basis the Austrian civil code of 1811, the Hungarian statute of tutelage of 1877, the Draft of the Hungarian private law code of 1928 and archived documents between 1872 and 1910.

Keywords: adoption, inheritance, Austrian civil code of 1811, the Draft of the Hungarian private law code of 1928

„A gyermekek nem pótolják a szerelmet, nem belyettesitik egy összetört élet célját, nem tárgyak, amelyek rendeltetése az. életünk üres részének megtöltése, felelösséget és nehéz feladatot jelentenek, a gyermekek nem a szülök játékszerei, sem pedig a kielégületlen ambicióik pótolói."

Simone de Beauvoir

\section{A kutatás tárgya és forrásai}

A tanulmány célja az örökbefogadás, mint jogintézmény létrejöttét elősegitő tényezők, körülmények feltárása, a jogintézmény megjelenésével a folyamatosan változó célok bemutatása, valamint összehasonlítása a magyar és az osztrák magánjog rendszerében. E tanulmány az Osztrák Polgári Törvénykönyvre (a továbbiakban: OPTK) és a magyar magánjogi törvénykönyv 1928-ban országgyúlés elé terjesztett javaslatára (a továbbiakban: MTJ) épül, valamint a Magyar Nemzeti Levéltár Baranya Megyei Levéltárában (a továbbiakban: MNL BML) az 1872-tôl 1910-ig fennmaradt levéltári iratok kutatásán alapul. A tanulmány bemutatja, hogy az OPTK milyen hatást gyakorolt a hazai szabályozás alakulására az örökbefogadás területén az anyaországban, és a Korona társországaiban az árván maradt gyermekek családban történő nevelkedése, a magtalan családok gyermekhez jutása érdekében.

Az örökbefogadás évezredes jogintézmény: nem csupán a római jog, hanem - valamilyen formában - a keleti jogrendszerek is ismerték. Eredeti célja az volt, hogy az örökbefogadott részesüljön az örökbefogadó vagyonában, vagyis az, hogy törvényes örökössé váljon. Az újabb polgári jogfelfogás az örökbefogadó és az örökbefogadott közötti családi kapcsolat létrehozásában látta az örökbefogadás célját, teljes családi kapcsolatot létrehozva az örökbefogadott és az 
örökbefogadó családja között. ${ }^{1}$ A megfogalmazott célok a társadalmi fejlődés során változtak, azonban az sem volt kizárt és nem kizárt ma sem, hogy párhuzamosan több célt is szolgáljon. ${ }^{2}$ Bacsó Jenô szerint az örökbefogadás nemcsak a magyar, hanem a legtöbb külföldi jogban is régóta fennálló olyan intézmény, amely tartalma az idôk folyamán a nemzetségfenntartó, vagyont egy kézben egyesítő szerződésből a gyermek nevelésének és gondozásának egyik hatékony eszközévé vált. ${ }^{3}$ Erre utal egyébként az intézmény neve is: a latin adoptio befogadás, rokonná fogadás, orosz uszinovlenyij vagy udocserenyij fiúvá vagy leánnyá fogadás, német Annabme an Kindes Stat gyermekké fogadás. Csupán a magyar elnevezés (örökbefogadás) utal a rokonná tétel mellett nyíltan arra, hogy a befogadás az örökössé tételt tűzte ki célul. ${ }^{4}$

Az ókorban, a római jog szerint az örökbefogadás elsődleges rendeltetése a család megerôsítése volt, ha arra egyéb lehetőség nem adatott meg (imitatio naturae). Akkoriban kizárólag nagykorú személyt lehetett örökbe fogadni. Célja egyfelől a családi név és többnyire kultikus feladatok továbbvitele, másfelől a hagyaték biztosítása, nemzetséghez való visszakerülés ellen. Az örökbefogadás öröklési jogi dominanciája sokáig még azután is megmaradt, hogy megjelent a szabad végrendelkezés.

Speciális célként jelent meg például a rabszolga-felszabadítás. ${ }^{5}$ A római jog az örökbefogadás két formáját ismerte: az arrogatiot valamint az adoptiot, azzal, hogy mindkét esetben az örökbefogadók csak önjogú római polgárok, családfők lehettek. Az arrogatio az önjogú személy, az adoptio valamely családfő hatalma alatt álló személy örökbefogadását jelentette. Az adoptio eredményezhetett atyai hatalmat (adoptio plena) vagy csak öröklési jogot (adoptio minus plena). Később nôk is fogadhattak örökbe, de ekkor is csak öröklési jogot biztosított az örökbefogadás. ${ }^{6}$

1. kép: Árvaházi reggeli (Vasárnapi Újság 1883)

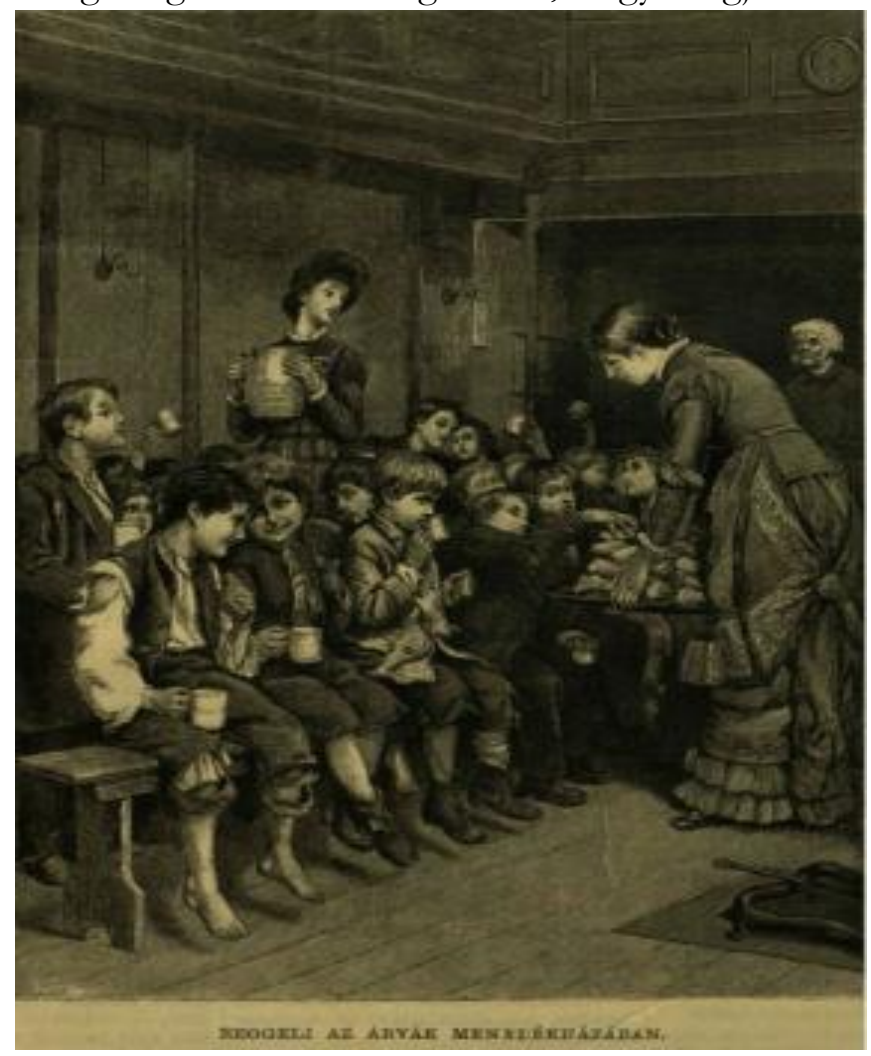

A hagyományos társadalom gyermekhez való viszonyát a mai ember számára nehezen feloldható ellentmondás jellemezte. A gyermeket Isten (illetve a kereszténység elótti korban a nem zsidó népeknél: az istenek) ajándékának tekintették. E családközpontú világképpel szoros

\footnotetext{
1 JobBÁGYI, Személyi és Családi Jog 11.

${ }^{2}$ KŐRÖS, A családjog kézikönyve I. 445.

${ }^{3}$ BACSÓ, Az örökbefogadás 17.

4 BACsÓ, Az örökbefogadás 609-616.

${ }^{5}$ FÓNAGY, Az örökbefogadás https://orokbe.hu/2014/06/30/az-orokbefogadas-tortenelmi-latoszogbol

${ }^{6}$ KATONÁNÉ PEHR, Az Örökbefogadás 32.
} 
összefüggésben állt az ősök tisztelete, sőt kultusza (aminek egyes elemeit, a maga képére formálva a kereszténység is fenntartotta). Ahhoz pedig, hogy az ember maga is bevonulhasson a tisztelettel őrzött emlékű ősök közé, neki is utódokra volt szüksége.

A család, a név fenntartásán túl a kétkezi munkát végzô túlnyomó többség - parasztok, iparosok - szemében a gyermek a családi gazdaság munkaerejeként is értéknek számított. A gyermekszülés illetve gyermeknemzés tehát az ember legfőbb élethivatása betöltésének számított. A gyermektelenségre - legyen az meddőség vagy gyermekhalálok következménye - „Isten veréseként” tekintettek, s gyakran valamely bűn megérdemelt büntetésének értelmezték. Ha minden erőfeszítés ellenére sem sikerült a gyermekvállalás, örökbe fogadtak valakit, mert - magyar paraszti szólással „nem akarták kutyára hagyni a nevüket.” A 20. század előtt gyakori volt a család felbomlása az egyik vagy mindkét szülő halála miatt, még mielőtt az összes gyermek elérte a felnőttkort. Ilyenkor a kicsi gyermeket az idősebb testvér, a nagyszülők vagy más rokonok nevelték. A megözvegyült szülők többnyire újraházasodtak, így sok családban találkozunk mostohatestvérekkel és mostohaszülővel. (Ezt tükrözik vissza a népmesék is, amelyeknek gyakori szereplője lett a gonosz mostoha.)

Ha a részletek változtak is az idők folyamán, az örökbefogadás lényege a polgári kor előtt ugyanaz volt: az egyenes ági leszármazottal nem rendelkezők elsősorban törvényes örökösről kívántak gondoskodni, hogy biztosítsák a család nevének fennmaradását, és rendezzék vagyonuk sorsát a haláluk utáni időre. ${ }^{8} \mathrm{Az}$ atya halálával megárvult gyermekekrôl eleinte az osztatlan vagyonközösségben élő férfi rokonok gondoskodtak és jártak el képviselőként. Minthogy még sokszor a 15. században is fennmaradt az osztály után a testvérek, unokatestvérek vagyonközössége, a gyámság intézménye meglehetősen későn, csak a 18-19. században jelent meg illetve terjedt el. A gyámi tisztet a nem törvényes korú árva felett a legközelebbi atyai ági férfi rokon vagy rokonok látták el, akik a gyermek után öröklésre voltak jogosultak. ${ }^{9}$ Az örökbefogadás tehát

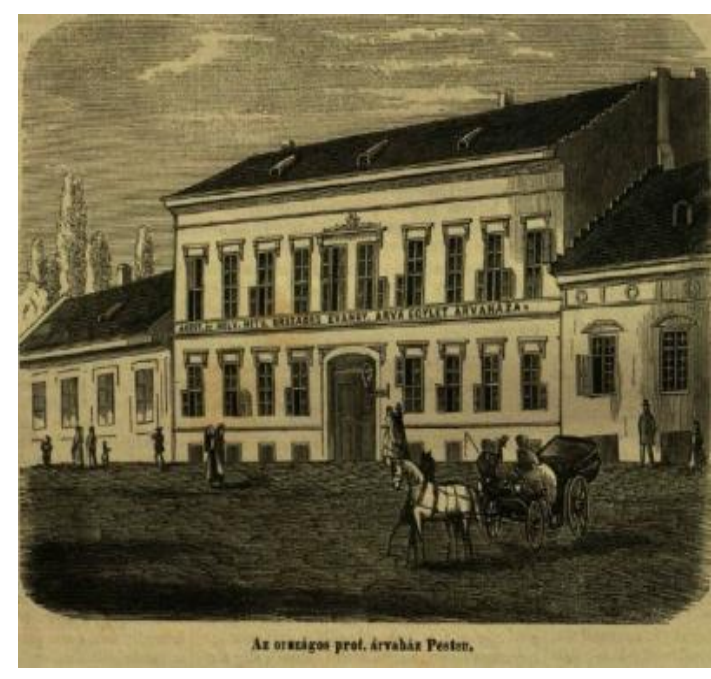
elsősorban öröklési jellegű szerződés (örökössé fogadás), azaz vagyonjogi aktus volt a régi jogfelfogás szerint. Az újkortól az örökbefogadás több funkcióssá vált: nagykorúak örökbefogadása elsősorban öröklési jogi célokat szolgált, életkortól függetlenül a név, a rang stb. továbbvitelének eszközeként jelent meg, de lehetôvé tette a házasságon kívül született gyermek törvényesítését is a házasságról, családról és a gyámságról szóló 1952. évi IV. törvény (a továbbiakban: CSJT) megalkotásáig.

2. kép: Protestáns árvaház (Vasárnapi Újság 1870)

Az örökössé fogadásnak természetesen csak azokban a rétegekben volt értelme, ahol jelentős javakkal rendelkeztek. A nemesi földbirtok - az ősiség értelmében - valójában a családé,

\footnotetext{
${ }^{7}$ MNL, Öröklés http://mek.oszk.hu/02100/02115/html/4-303.html

${ }^{8}$ FÓNAGY, Az örökbefogadás https://orokbe.hu/2014/06/30/az-orokbefogadas-tortenelmi-latoszogbol

${ }^{9}$ BÉLI, Magyar Jogtörténet 62.
} 
nemzetségé volt, nem az egyéné. Ha valaki gyermektelenül halt meg, akkor azt az atyafiság örökölte, a jog által meghatározott rendben - végrendelkezni az örökölt családi birtokról nem lehetett. Az örökbefogadás volt az egyetlen módja, hogy mégis a birtokos személyes akarata érvényesüljön a halál után. A birtokos - a vagyon családban tartása érdekében - leggyakrabban a rokonok közül választott örököst, például valamelyik testvére fiát fogadta örökbe. Mivel az örökössé fogadás célja nem a gyerek felnevelésének biztosítása, illetve valamely érzelmi hiányérzet kielégítése volt, így nem kellett, hogy a gyermek árva vagy elhagyott legyen. Sőt, a jogi aktus következtében nem is feltétlenül került át az örökbe fogadó családjába. A magyar jogrend egészen a CSJT-ig ismerte az adoptio minus plena formulát, azaz a szülői felügyeleti jog átszállása nélküli örökbefogadást.

A fogalom mai tartalmától szintén idegen, hogy a majdani örökösként örökbefogadott akár felnőtt is lehetett. Fiú utód nélküli nagybirtokosok a csak fiágon öröklődő birtokokat vagy a lányuk fiúsításával őrizték meg leszármazottaik számára (királyi engedélyt szereztek lányuk öröklésére), vagy örökbe fogadták a vejüket. A birtokos nemesség esetében nemcsak a rokonság volt ellenérdekelt az örökbefogadással szemben, hanem a királyi kincstár is: törvényes örökös híján ugyanis a birtok arra háramlott volna. Sőt, nem örült az örökös-fogadásnak az egyház sem, mivel a gyermektelenek végrendeletükben gyakran igen bőkezűen hagyatkoztak kegyes célokra. Azoknál a társadalmi rétegeknél, ahol a család, illetve a háztartás a termelőmunka kereteként is szolgált parasztok és iparosok - a gyermeknek munkaerőként is fontos szerepe volt. ${ }^{10} \mathrm{Ez}$ a szempont természetesen érvényesült az örökbefogadással kapcsolatban is. A parasztcsaládok örökbefogadási gyakorlatáról a 19. század végérôl, a 20. század első feléből vannak néprajzi forrásaink. Gyermek hiányában ők is elsősorban a közeli rokonság körében kerestek örökbefogadásra alkalmas fiút.

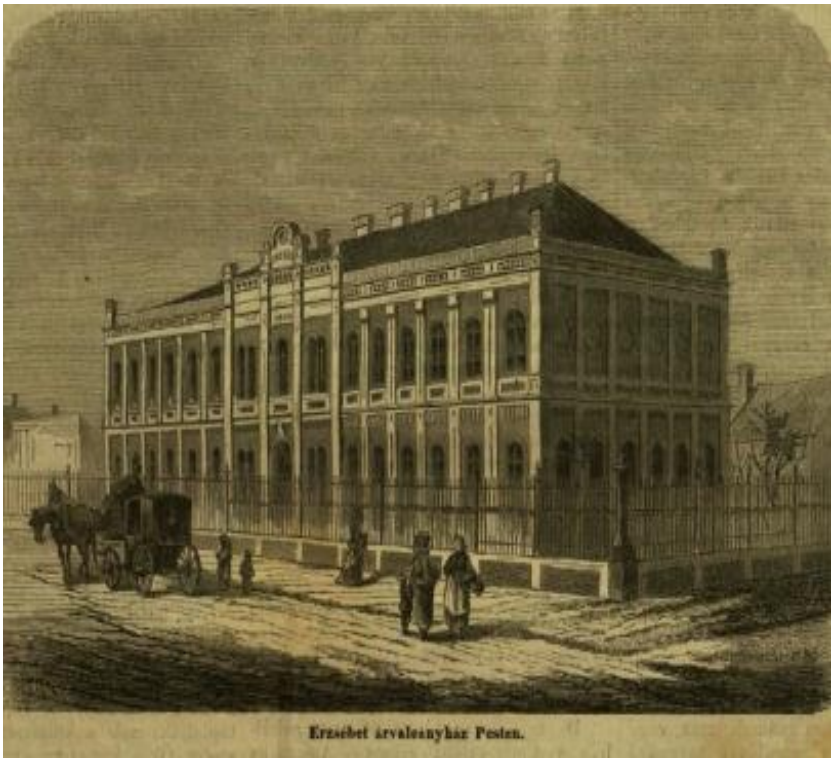

Leggyakrabban többgyermekes testvéreiktől választottak egyet, leginkább a legfiatalabbat. Alkalmas rokongyerek híján számításba jöhetett árva, a századfordulótól - az állami gyermekmenhelyek alapításától kezdve lelencházi gyerek is. Általában egészen fiatal gyermeket hoztak el a menhelyröl, majd ha megszerették, örökbe is fogadták. Voltak jobb módú családok, ahol a munkáskéz biztosítása céljából 2-3 gyereket is örökbe fogadtak.

3. kép: Leány árvaház (Vasárnapi Újság 1872)

Különösen gyakori volt az örökbefogadás a belterjes, munkaerő-igényes gazdálkodást folytató falvakban, például a dél-alföldi dohányosoknál és zöldségkertészeknél. A tanyai gazdálkodásban is előnyt jelentette a családbeli több olcsó munkaerő, amely az örökség vagy

\footnotetext{
${ }^{10}$ Herger, A közszerzemény megosztása 93. és Hegedűs, Családjog 207.
} 
legalább a kiházasítás reményében szorgalmas munkával gyarapította a családi vagyont. ${ }^{11}$ A nagyobb gazdák már az örökbefogadás alkalmával ráírattak a gyerekre valamilyen birtokrészt, a kevésbé tehetősek pedig egy öltözet ruhával vagy kisebb használati tárggyal ajándékozták meg. A nagyobbacska legények esetleg ki is kötötték az örökbefogadás feltételéül, hogy előzőleg földet írassanak rájuk, nehogy hiába essen a munkájuk. A 20. század elejétől a paraszti világban a tehetős gazdáknál akkor is előfordult örökbefogadás, ha voltak gyermekeik. Ilyenkor az örökbefogadott „nem egész örökös” volt, azaz nem számíthatott egyenlő örökösödésre. Öt munkája fejében fölnevelték, kiházasították és az induláshoz adtak neki valamit a vagyonból is. A parasztság körében csak a teljes jogú örökbefogadást ismerték, azaz a gyermek bekerült a családba, új apja, akinek a nevét, sőt még a ragadványnevét is viselte, a teljes atyai hatalmat gyakorolta felette. Helyzete a családon belül ugyanaz volt, mint a vér szerinti gyermeké. Neve sokfelé „örökös gyerek” volt, ami utalt az örökbefogadás régebbi tartalmára. ${ }^{12}$

Az örökbefogadás jogi aktusának a tradicionális jogban nem volt egységes és általános szabályozása, ezen a téren is a „kinek-kinek a magáét’ elv érvényesült. Azaz a rendi állás számított: a nemes a vármegyén, illetve a kormányszerveken keresztül a királytól szerzett megerősítést szándékára, a jobbágy a földesúrtól, a polgár pedig a városi magisztrátustól. ${ }^{13}$

\section{Az örökbefogadás az osztrák természetjogi kódexben}

Az örökbefogadás intézménye a német jogkörben későn, római jogi hatásként jelent meg. Ahogy a magánjogi intézmények többsége, úgy az örökbefogadás is a római jogban jelent meg először, mint jogilag szabályozott aktus. Ennek az intézménynek a segítségével már a kezdetektől fogva a természetes utódok hiányát kívánták pótolni, vigaszt nyújtott az elvesztett gyermekekért ${ }^{14}$, de egyúttal az örökhagyó még életében gondoskodhatott arról, hogy legyen, aki tovább vigye a nevét, vallási és egyéb kötelességeit, gondoskodjon a fennmaradó családtagjairól amellett, hogy vagyonát örökölje, s ez utóbbi volt az elsődleges célja, mégis családjogi intézményként jelent meg. ${ }^{15}$

A germán népek jogéletében a római jogi manus intézményével rokonítható Munt különböző formái voltak ismertek (férj Muntja felesége felett, a családfő Muntja gyermekei felett és a családi házközösséghez tartozó más személyek, így rokonok és házi szolgák felett), és így az árva feletti gyámi Munt, amelynél fogva örökbefogadásra nem volt szükség, mivel a nemzetség legidősebb férfitagjának gyámi hatalma pótolta azt. Ilyen módon a német jogfejlődésben a gyámság intézménye bizonyos értelemben az örökbefogadás előzményének is tekinthető. A germán jog megkülönböztette az ún. szerződési rendszert (Vertragsystem) az ún. rendelet rendszertől (Dekretsystem). Előbbi azt jelentette, hogy az örökbefogadó és a gyermek között kötött szerződéses jogviszony által jön létre az örökbefogadás, míg a rendeleti rendszer szerint szuverén állami aktus (Hoheitsaket) hozza létre a jogintézményt. Jelentős különbség a kettő között, hogy az örökbefogadó rokonságágára is kihat-e az örökbefogadás (Volladoption) annak minden joghatásával vagy csupán

\footnotetext{
${ }^{11}$ MNL, Öröklés http://mek.oszk.hu/02100/02115/html/4-303.html

12 MNL, Öröklés http://mek.oszk.hu/02100/02115/html/4-303.html

${ }^{13}$ FÓNAGY, Az örökbefogadás https:// orokbe.hu/2014/06/30/az-orokbefogadas-tortenelmi-latoszogbol

${ }^{14}$ WEISS, Az örökbefogadás néhány társadalmi és jogi kérdése 180.

15 BEKE-MARTOS, Az örökbefogadás - jogtörténeti megközelítésben 18.
} 
az örökbefogadó és az örökbefogadott gyermek között keletkeztet jogokat és állapít meg kötelezettségeket (Teilwirkungen). ${ }^{16}$

A természetjogi kódexek közé sorolt, 1811-ben elfogadott OPTK már ismerte az örökbefogadás intézményét. Szabályozása nem csak azért érdekes, mert megmutatja, milyen tartalmat hordozott ez a gyerekcipőben járó intézmény az osztrák örökös tartományokban, hanem azért is, mert 1853-ban hatályba lépett Magyarországon, valamint Horvátországban, Szlavóniában, a Szerb Vajdaságban, a Temesi Bánságban és Erdélyben is. Korszerú magyar rendelkezések hiányában nagy szükség volt az osztrák kódex szabályaira az örökbefogadással kapcsolatos jogvitákban. Sôt, bár az Ideiglenes Törvénykezési Szabályok 1861-ben a tradicionális magyar magánjog jelentős részét helyreállították a neoabszolutizmus erőszakos jogexportja után, az osztrák kódex rendelkezései az örökbefogadás esetében az 1877. évi XX. törvénycikk (ún. Gyámtörvény) megalkotásáig hatályban maradtak. ${ }^{17}$

Az OPTK-t 1870-ben másodszor is kiadták Pesten hivatalos magyar nyelvű fordításban, amit ugyan az is indokolt, hogy 1861-ben csak részleges lehetett a visszatérés a magyar tradicionális magánjoghoz, de elsősorban arról volt szó, hogy a magyar Korona mellékországaiban az OPTK továbbra is hatályban volt és ezért a királyi Curia a magyar és az osztrák jogot párhuzamosan alkalmazta az elé került ügyekben. A fent említett kiadás fordítását idézve az OPTK III. fejezete (A szülék és gyermekeik közötti jogokról, azonbelül a szülék és gyermekeik közti jogviszonyhoz hasonló összeköttetések címszó) foglalkozik az örökbefogadás jogintézményével mindössze 7 \-on keresztül. A törvénykönyv szerint „azok, kik házasságtalanságot ünnepébyesen nem fogadtak, ha törvényes saját gyermekeik nincsenek, gyermekeket örökbe felvehetnek: a felvevö személy fogadó-atyának vagy anyának, a felvett pedig fogadott gyermeknek neveatetik" (179. §). ${ }^{18}$ Az örökbefogadó személyét illetően a törvény mindössze egy feltételt támasztott, mégpedig az életkor tekintetében: az ötvenedik életév betöltése, egyszersmind az örökbefogadott gyermeknél legalább 18 évvel idősebb személy (180. J). A törvénykönyv mind a kiskorú, mind a teljeskorú gyermek örökbefogadását lehetővé tette, aszerint differenciált, hogy kinek a beleegyezése szükséges az örökbefogadáshoz. Teljeskorú fogadott gyermek esetén az atyja beleegyezése megkívántatott, kiskorú gyermek örökbefelvételénél elsősorban az atya, ha az atya nem élt, akkor az anya, a gyám, a bíróság belegyezésére volt szükség. Amennyiben az atya elegendő ok nélkül tagadta meg az örökbefogadást, a törvény jogorvoslatként panasztételt engedett a rendes bírónál. Az örökbefelvételt be kellett jelenteni, mely egyrészről a kormányszék által végzett megerősítés, másrészről pedig a bírósági nyilvántartás miatt volt kiemelten fontos (181. §).

A törvény az örökbefogadás joghatásai közül a névviselést és a családi kapcsolatot szabályozta. A fogadott gyermek vagy a fogadó-atya nevét vagy a fogadó-anya nemzetségi nevét, de egyszersmind a fogadó-atya családi nevét, és az ôt illető családi nemességet is megtartja (182. §). Nemesség, címer átszállásához a fejedelem engedelmére volt szükség. A családi kapcsolatot illetôen a fogadott gyermek és utódai a fogadó atya atyai hatalma alá kerültek, ugyanazon jogállás illette meg

\footnotetext{
16 SCHWAB, Familenrecht 300.

17 VÉKÁs, Az osztrák Polgári Törvénykönyv 22-28.

18 Örökbe-fogadott: Kit valaki saját gyermeke gyanánt fogad, nevel, és javainak örökösévé tesz. Örökbefogadott árva. Lásd: CZUCZOR - FOGARASI, A magyar nyelv szótára http://mek.oszk.hu/05800/05887/cimkes.html
} 
őket, mint a saját gyermekeket, ugyanakkor az örökbefogadás nem terjedt ki az örökbefogadó szülők családjának többi tagjaira, csupán a fogadó atya, anya és a fogadott gyermek viszonylatában hozott létre családi jogállást, létesített jogokat és kötelezettségeket, amely jogviszonyban a fogadott gyermek nem vesztette el önnön családja jogait (183. §). A kódex által szabályozott - fogadott gyermek és fogadó szülék közötti jogoktól - a felek szerződésben eltérhettek, ha mások jogai nem rövidültek, valamint ha a szerződés lényeges változást nem tartalmazott az említettekhez képest (184. §). A fogadó szülék és a fogadott gyermek közötti kötelezettségeket a törvény nem említette, nem szabályozta. Elenyésztők címszó alatt a felbontható örökbefogadás mellett foglalt állást, mely védte a kiskorú gyermek érdekeit, annak fennállása esetén csak a gyermek képviselói és a bíróság beleegyezésével volt megszüntethető. Amennyiben az örökbefelvétel, mint jogviszony elenyészett, a gyermek ismételelten törvényes atyja hatalma alá került vissza (185. §). Az örökbefogadás jogai és kötelezettségei olyan gyermekre nem vonatkozhatott, akik egyedül tápolás végett véttettek fel. Ez a tápolás mindenki szabadságában állt, ha azonban a felek eziránt szerződésre akartak lépni, akkor a tápgyermek jogait megszorították, rá „,különös köteleztetések” vonatkoztak, melyet bíróság előtt meg kellett erősíteni. A tápolás költségeit a tápszülék nem követelhették (186. §).

\section{Az örökbefogadás szabályozása Magyarországon}

Az örökbefogadás célja, rendeltetése a magyar jogfejlődésben is hosszabb időn át elsődlegesen az öröklés volt. Az örökbefogadás magyar kifejezése az „örökségbe” fogadást, azaz az örökössé tételt jelentette. ${ }^{19} \mathrm{~A}$ tradicionális magyar magánjog ismerte az adoptio filialis intézményét. Örökbefogadás által az szerzett nemességet, akit a magvaszakadt ${ }^{20}$ nemes királyi hozzájárulással fiává fogadott és ezzel adományos birtokaiban örökösévé tett. Az örökbefogadás érvényességi feltételei a fiúsításéval (praefectio) ${ }^{21}$ egyeztek meg. A fiúsítás azt jelentette, hogy a fiágon magvaszakadt nemes leányát vagy nőrokonát a férfiakat illető öröklési joggal ruházta fel a király. A fiúsítás lehetősége miatt a magyar nemesi jogéletben az örökbefogadás intézményére korlátozottan volt csak szükség.

A magyar jogfejlődés jellegzetessége, hogy az örökbefogadást már a Tripartitum is tartalmazta, és megengedett volt a kiskorúak és a nagykorúak örökbefogadása (a germán joghoz hasonlóan) az öröklés céljával: Werböcryy István először 1517-ben Bécsben kiadott jogkönyve, mely a teljes magyar jog (szokások és törvények) feljegyzése volt, a nemesség magánjogi viszonyai kapcsán szabályozta az örökbefogadás intézményét, rendelkezett a testvérré fogadásról is. A Tripartitum az örökbefogadást elsősorban a nemessé válás egyik lehetséges módjaként tárgyalta. Ha ugyanis nemes nem nemest fogadott örökbe, azt a majdan megöröklendő birtok nemessé tette. Igaz, ehhez királyi megerősítést is kellett szerezni, ugyanúgy, mint ha a család főnemesi (grófi, bárói) címét akarták megmenteni. „Továbbá még más módon is lehet valaki nemessé; örökkbe fogadás útján: a mikor

\footnotetext{
${ }^{19}$ KATONÁNÉ PeHR, Az örökbefogadás 37. Örökbefogadás: Cselekvés, midőn valakinek természetes örököse nem lévén, idegent veszen föl saját gyermekéül és örököséül. Lásd: CZUCZOR - FOGARASI, A magyar nyelv szótára http://mek.oszk.hu/05800/05887/cimkes.html

${ }^{20}$ Magvaszakadt: Mondjuk emberről, kinek gyermeke, s örököse nincsen, kiben a nemzetség vagy család kihal. Innen magvaszakadt jószág am. örökös nélküli, rendszerént az állodalomra szálló jószág. Lásd: CZUCZOR - FOGARASI, A magyar nyelv szótára http://mek.oszk.hu/05800/05887/cimkes.html

${ }^{21}$ Fiúsítás: A magyar törvényben am. a leányt fiúi jogokkal felruházza, a fiút illető örökséget reá hagyja. Lásd: CZUCZOR - FOGARASI, A magyar nyelv szótára http://mek.oszk.hu/05800/05887/cimkes.html
} 
tudniillik valamelyik úr vagy nemes valamely parasztot vagy nem nemest fiaként örökbe fogad és fekvoó jószágainak utódjává és örökësévé rendel; ha az ilyen örökbe fogadáshoz a királyi jóvábagyás járul és ezt a jószágaiba való törvényes beiktatás is követi (mivel a₹ örökbefogadásnak épen úgy, mint a fiusitásnak királyi jóvábagyás mellett adományereje van) az a nem nemes és ennek. fiai igazi nemesek számába jönek”" (8. cím). „Készakarva mondám pedig: örökeösök hiányában, mert ha valóságos és törvényes örökösök és utódok létęnek és maradnak hátra, a testvérré fogadásnak helye nincsen; de ezeknek biányában ama fekvoó jószágok háramlására nézve, az. ilyen utódlás batalmára és jogára a testvérré vagy fiúvá fogadott fog sžert tenni” (66. cím 3. \$). „Mivel a gyámság átszállása, mint már elóbb mondám, a fekvoó jószágok háramlása sz̧erint történik, ažért, ha valakinek fiágban magvaszakad és leányai vannak, a gyámság viselése azokera azörökebe fogadott atyafiakra is, mint fiági rokonokera jogosan átszáll és átmegy, a kikere valamely szerzôdés vagy királyi jóváhagyás erejénél fogva a magvaszakadtnak fekvoó jószágai és birtokjogai háramlanak, a minek bármely leányágai rokon joga és gyámsága útját nem állja (120. cím 1.\$). (Például a 20. század elején a gyermektelen utolsó Benyous₹łky gróf, Sándor a család nemesi ágából fogadott örökbe két fiút, akik ekkor már 28, illetve 30 évesek voltak.) ${ }^{22}$

Az OPTK magyarországi hatályba léptetése témánk szempontjából azt jelentette, hogy az örökbefogadás természetjogi szemlélettel és törvényi jogi szabályozással lett a magyar magánjog része mindaddig, míg (hasonló szabálytartalommal) saját magyar törvény nem született ebben a tárgyban 1877-ben.

A gyámsági és gondnoksági ügyek rendezéséről szóló 1877. évi XX. törvénycikk anyagi jogi és eljárásjogi rendelkezéseket is tartalmazott. A törvény szerint a gyámhatóság legfőbb feladata a gyámoltak és gondnokoltak szellemi és anyagi érdekeinek az előmozdítása, valamint a megóvása volt. Rendkívül sokrétű feladatot első fokon a törvényhatóságok és a rendezett tanácsú városok, kivételképpen pedig a községek árvaszékei látták el.23 A törvény abból az aspektusból indult ki, hogy a gyámügyekben a községnek, valamint a családnak is kellő befolyást kell biztosítani, így szakítani kíván a 16. századbeli irányzattal, mégpedig: amely szerint az állam intézi, kezeli és igazgatja a gyámügyeket a család és a község kizárásával, a gyámot a gyámhatóság mechanikus közegének tekintve. Így tehát be kell vonni a családot és a községeket a gyámhatósági munkába. A törvénycikk két részből állt: az első rész a gyámságról és a gondnokságról, valamint az ehhez kapcsolódó jogintézmények szabályozásáról, a második rész pedig a gyámhatóságokról és a hozzá kapcsolódó jogintézmények szabályozásáról szól. A törvény megállapította, hogy a kiskorú cselekvőképessége a 12. életév betöltésével kezdődik, a teljes nagykorúság határát pedig a 24. életévben jelölte meg. Általános elvként szögezte le a törvény, hogy a kiskorúak gyámság vagy atyai hatalom alatt állnak, valamint az atyai hatalom és gyámság egymást kizáró jogintézmények, így együtt meg nem állhatnak. ${ }^{24}$

A törvény a gyámságra hivatott személyek sorrendjét is megállapította. A gyámok tekintetében a római jogi eredetű csoportosítást használta, amelyet már a régi jogunk is követett. Így tehát megkülönböztetünk nevezett, természetes és törvényes (törvényes és rendelt) gyámot. Amennyiben az elhalt atya nem nevezett meg gyámot, úgy a gyám tisztsége az anyára, mint természetes és törvényes gyámra szállt, abban az esetben viszont, ha az atya nevezett gyámot, akkor

\footnotetext{
22 FÓNAGY, Az örökbefogadás https:/ / orokbe.hu/2014/06/30/az-orokbefogadas-tortenelmi-latoszogbol

23 ZÁmBÓ, A gyámhatóságok 1. Lásd továbbá: Árvaszék: Árvák ügyeire vonatkozó tanácskozmány vagy tárgyalás; árvabiróság. Lásd: CZUCZOR - FOGARASI, A magyar nyelv szótára http://mek.oszk.hu/05800/05887/cimkes.html ${ }^{24}$ SISKA, Az árvaszékek története és jogi szabályozása 118-119.
} 
a gyámi tisztség a nevezett személyt illette meg, az anya pedig csak azt követelhette, hogy a kiskorú gyermekeit magánál tarthassa és azok személyi, valamint vagyoni ügyeiben őt meghallgassák.

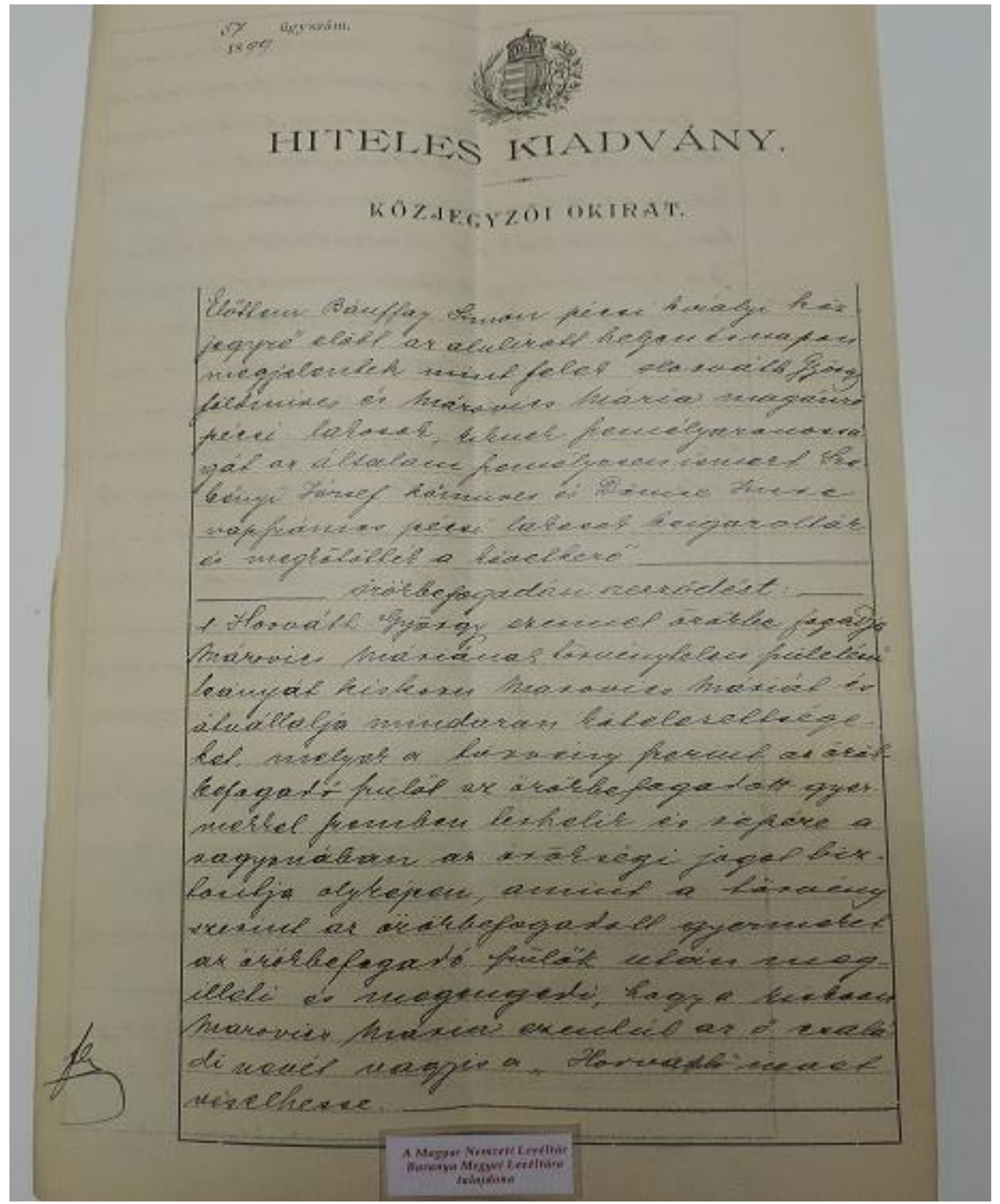

4. kép: Törvénytelen gyermek örökbefogadásáról rendelkező örökbefogadási szerződés MNL BML IV. 1409.b. II-891899 
A törvénycikk 43. \-a kizárta a nőket a gondnokság és a gyámság viseléséből. Az árvaszékek törvényi szabályozását követően az 1877. évi 47046. számú rendeletével a belügyminiszter szabályozta az árvaszékek ügyrendjét. Ezzel befejeződött az árvaszékek egységes központi szabályozásának menete. ${ }^{25}$

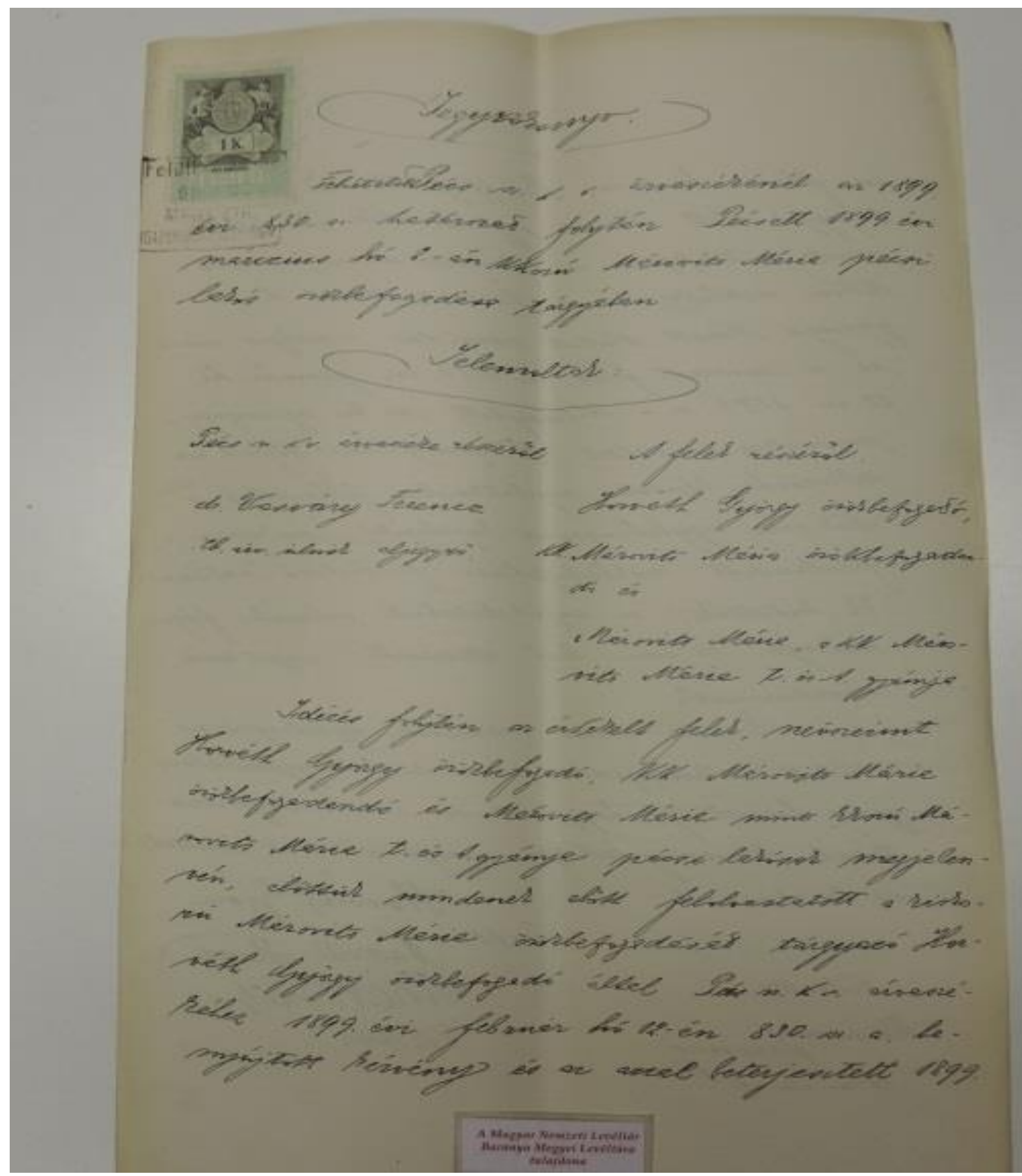

5. kép: Pécsi lakosú kiskorú gyermek örökbefogadása tárgyában készült jegyzőkönyv MNL BML IV. 1409.b. II-891899

${ }^{25}$ SISKA, Az árvaszékek története és jogi szabályozása 124-128. 


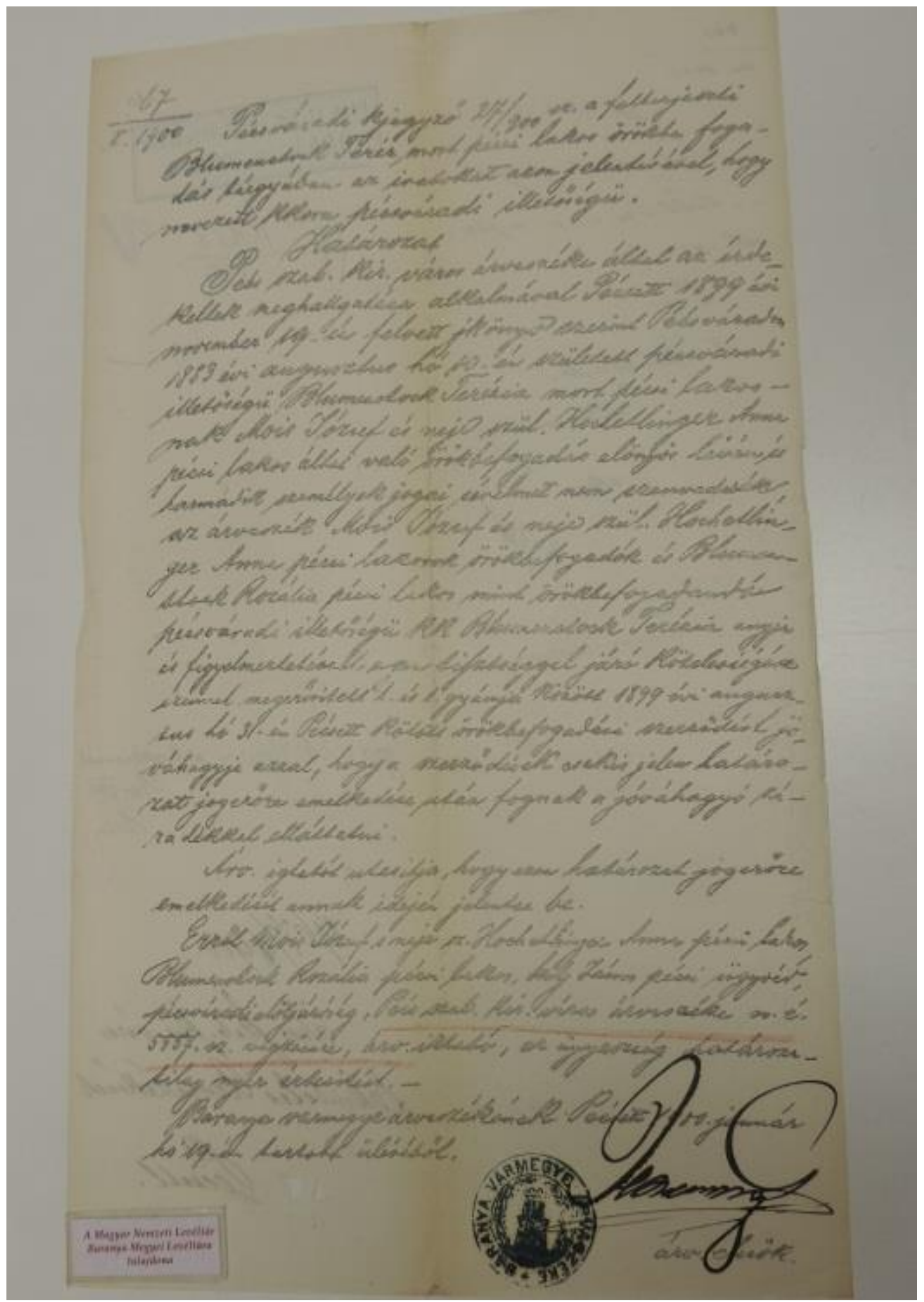

6. kép: Baranya Megye Árvaszékének határozata az örökbefogadás jóváhagyásáról MNL BML IV. 1904.b II-1008-1899 
Márkus Dęsṓ tanítványa, Meszlény Artúr egyetemi tanár, ügyvéd által írt, 1931-ben megjelent Magyar magánjog I. c. mű szükségessége abból következett, hogy a magánjogi kodifikáció hazánkban sikertelen volt. A magánjogi kódex 1900. évi I. tervezetét ugyan további négy követte a századforduló utáni első két évtizedben, melyeket nagy szakmai igényességgel dolgoztak ki, az Országgyúlés elé terjesztett $\mathrm{V}$. tervezet elfogadása 1928-ban elmaradt. Mes₹lény három évvel később úgy egészítette ki Márkus Dęső́ századforduló éveiben kiadott Magyar magánjog c. mûvét, hogy annak alapját az MTJ képezte: a javaslatból idézett szakaszok tartalmát mutatta be a magyar jogfejlődés egészére nézve. Ezáltal pontos képet adott arról, hogy hogyan alakult az adott szokásjogi jogintézmény a bírói jogban és arra tekintettel a kodifikátorok milyen álláspontot alakítottak ki. Közvetett hatása ennek a módszernek az volt, hogy segítette a törvényként el nem fogadott ún. kodifikálatlan kódex tartalmának a mindennapi jogéletbe való átvételét.

Az MTJ az örökbefogadás intézményét az OPTK-hoz képest lényegesen részletesebben szabályozta. Az örökbefogadás érvényes létrejötte feltételeként nem kívánta meg, hogy a leendő fogadó szülő házasságtalanságot fogadjon, csupán annak a három feltételnek kellett teljesülnie, hogy nagykorú legyen, ne legyen ivadéka, és legalább tizenhat év korkülönbség álljon fenn az örökbefogadó szülők és örökbefogadott között. A törvénykönyv magyarázata szerint ivadék alatt a lemenő rokont kellett érteni (175. §), nagykorú személy pedig az volt, aki a 24. életévét betöltötte (16. §) Kivételt képezett e szabály alól, a különös méltánylást érdemlő eset, melynek fennállása esetén az igazságügyminiszter megerősíthette az örökbefogadó szerződést akkor is, ha az örökbefogadónak vérszerinti ivadéka volt vagy a korkülönbség kelléke hiányzott, de legalább tizenkét évvel idősebb volt az örökbefogadó szülő az örökbefogadottnál (207. \$). A hazai jog nem kívánta meg azt, hogy az örökbefogadó legalább ötvenéves legyen, ez a követelmény csak azon örökbefogadók tekintetében állt fenn, akik a haza azon területén éltek, ahol az osztrák polgári törvénykönyvet ideiglenesen hatályban tartották. A törvény nagykorú örökbefogadását is megengedte. Nagyszülő örökbe fogadhatta unokáját, ugyanazon örökbefogadó a szülőt és annak gyermekét is ${ }^{26}$, a gyám gyámoltját, izraelita vallású egyén a keresztény vallású kiskorú egyént ${ }^{27}$, de a gondnokság alatt álló személyeket is örökbe lehetett fogadni ${ }^{28}$, ahogy nemes ember parasztot is örökbe fogadhatott. ${ }^{29}$ Törvényesített, saját gyermek örökbefogadását a törvény expressis verbis kizárta, azonban lehetôvé tette, hogy a természetes atya saját törvénytelen (utóházassággal nem törvényesített) gyermekét örökbe fogadja (704. \). ${ }^{30}$ A törvény tilalmakat is felsorolt, mégpedig a testvérek közötti örökbefogadást ${ }^{31}$, a magzat (nasciturus) örökbefogadását ${ }^{32}$, a házastársnak saját házastársa, vagy házastársa elődjének örökbefogadását. Előd alatt a felmenő rokont kellett érteni (175. S). Az MTJ kimondta, hogy hazai jogunkban nem létezik szabály, mely Magyarországnak az osztrák polgári törvénykönyv uralma alatt álló részein kívül lakó egyéneknek, ha törvényes leszármazóik vannak, az örökbefogadást megtiltaná (207. \). Több örökbefogadó ugyanazt a személyt nem fogadhatta örökbe, a házastársak kivételével. Az örökbefogadás fennállása alatt az

\footnotetext{
${ }^{26}$ MESZLÉNY, Magyar Magánjog I. 694.

27 MESZLÉnY, Magyar Magánjog I. 695.

28 MESZLÉnY, Magyar Magánjog I. 698.

${ }^{29}$ MeszLÉnY, Magyar Magánjog I. 704.

30 MeSZLÉNY, Magyar Magánjog I. 711. valamint 19405/1887 I.M. sz.

31 Meszlény, Magyar Magánjog I. 695.

32 MESZlénY, Magyar Magánjog I. 698.
} 
örökbefogadott gyermeket csak az örökbefogadó házastársa fogadhatta örökbe. Az örökbefogadó halála után az igazságügyminiszter különös méltánylást érdemlő esetben ezen tilalom alól kivételt tehetett $^{33}$ (208. §). A házastárs csak a másik házastárs beleegyezésével fogadhatott és volt örökbe fogadható, kivéve, ha ágytól és asztaltól el voltak választva. ${ }^{34}$ A törvény ez alól is kivételt tett, kimondta, hogy az egyik házastárs jogosítva van egyedül, házastársa beleegyezése nélkül is örökbe fogadni. ${ }^{35}$ Közös gyermekké fogadásnak nevezi a törvény, ha az egyik házastárs a másik házastárs gyermekét fogadja örökbe, kivéve, ha a feleség fogadja örökbe férjének házasságon kívüli gyermekét (208. §).36A Magyar Nemzeti Levéltár Baranya Megyei Levéltárában 1872-1910 között megtalálható iratanyagok többsége házastársi örökbefogadásról szól, mind a feleség, mind a férj oldaláról nagyszámban fordult elő olyan örökbefogadás, amikor a házastársa házasságon kívül született (törvénytelen) gyermekét fogadta örökbe.

A törvény részletesen szabályozta, hogy mely személyek beleegyezésére volt szükség az örökbefogadáshoz (209. §). Kiskorú törvényes gyermeket csak szülőinek, kiskorú házasságon kívüli gyermeket csak az anyja beleegyezésével fogadhatták örökbe. A beleegyezést közhatóság előtt kellett jegyzőkönyvbe mondani, vagy közokiratban kijelenteni, mely beleegyezés nem volt visszavonható. Annak a személynek a beleegyezését, aki távol volt, cselekvőképtelen vagy a nyilatkozat megtételében tartósan gátolva volt, mellőzték. ${ }^{37} \mathrm{~A}$ felek örökbefogadás iránti szándékát - valamint, ha az örökbefogadandó gyermek a 14. életévét betöltötte az ő véleményét - az eljáró árvaszék vagy a lakóhelyükhöz legközelebb eső szolgabíróság vette jegyzőkönyvbe.

Az atyai hatalmat gyakorló atya vagy a gyám kérelmezhette az örökbefogadás gyámhatósági jóváhagyását, az erre vonatkozó kérelemhez csatolni kellett az örökbefogadó és az örökbefogadott keresztelő vagy születési bizonyítványát; amennyiben a gyermek törvénytelen származású volt, akkor az édesanyjának a születési vagy keresztelő bizonyítványát is; ha az örökbefogadók házastársak voltak, akkor a házassági bizonyítványukat; amennyiben a törvényes atya, vagy a törvénytelen születésű örökbefogadandónak anyja vagy a szülők egyike sem élt, akkor a halotti bizonyítványokat, valamint a gyám által képviselteknél a gyámi rendelvényt. A kérvény felett az árvaszék, mint gyámhatóság döntött. Amennyiben az örökbefogadást a kiskorú érdekében állónak tartotta határozatában jóváhagyta, jogerő után záradékolta, a szerződés három példányát felterjesztette az igazságügyminiszterhez végső elhatározás végett. ${ }^{38}$

Levéltári kutatásaim alapján az örökbefogadási szerződések többsége azzal indokolta a gyermek érdekében álló örökbefogadást, hogy annak létrejöttével a gyermek családi jogállása rendeződik (tehát törvénytelen származása megszűnik), örökösödési jogot (beleértve a kötelesrészt is), atyai hatalmat kap és jogosult viselni az örökbefogadó családnevét. Az áttekintett levéltári iratok mindegyike az örökbefogadott gyermeket saját családi nevének elhagyásával az örökbefogadó családnevének viselésére kötelezte.

\footnotetext{
33 MeSZLÉNY, Magyar Magánjog I. 696.

34 MESZLÉNY, Magyar Magánjog I. 697.

35 MesZlénY, Magyar Magánjog I. 697.

36 MESZLÉNY, Magyar Magánjog I. 703.

37 MESZlÉNY, Magyar Magánjog I. 697.

38 MesZLÉNY, Magyar Magánjog I. 699-700.
} 
Aktív örökbefogadási képessége a teljeskorú és önrendelkezési joggal bíró magyar állampolgárnak volt (208. §).39 A vallási hovatartozás az örökbefogadási képességet nem befolyásolta: görög-katolikus, görög-keleti, protestáns, izraelita rabbi is örökbe fogadhat, kivéve a római katolikus lelkész és az ünnepélyes fogadalmat tett lelkészek. Aki házasságot egyházi rend vagy fogadalom okán nem köthetett, az a személy csak egyházi felsőbbség engedelmével fogadhatott örökbe (210. §).40

Az örökbefogadó szerződést az örökbefogadónak magával az örökbefogadandóval kellett megkötnie.41 Az örökbefogadás iránt szerződő nagykorú felek gondoskodtak a szerződés anyagi és alaki szabályszerűségéről. Amennyiben az örökbefogadandó tizenkettedik életévét nem töltötte be, a szerződést a gyámhatóság jóváhagyásával a kiskorú törvényes képviselője kötötte meg az örökbefogadóval. ${ }^{42}$ A kiskorú törvényes képviselője elsősorban az atyai hatalmat gyakorló atyja volt, ha az atya nem élt, vagy az örökbefogadott törvénytelen születésú volt akkor az anya, ha az atyai hatalom gyakorlata felfüggesztetett vagy egyik szülő sem élt, akkor az árvaszékileg kirendelt gyám következett a sorban, aki megköthette az örökbefogadó szerződést (211. 』).43 E szerződést három eredeti példányban közokiratba kellett foglalni, kivéve, ha királyi közjegyző előtt köttetett, mert akkor három hiteles kiadványa készültt. ${ }^{44} \mathrm{~A}$ szerződő felek szegény sorsára tekintettel a törvény kivételt engedett az írásbeliség alól, mert az árvaszék előadója vagy az árvaszék által megbízott szolgabíró előtt szóban is megköthető volt. Levéltári kutatásaim bizonyítják, hogy gyakran éltek ezzel a lehetőséggel a szegény körülmények között élő családok, akik szegénységi bizonyítvánnyal igazolták állitásukat és kérték, hogy a szükséges okmányokat az árvaszék szerezze be. ${ }^{45}$

Az örökbefogadási szerződésbe belefoglalták mindazon jogokat (öröklési jog, névátruházás stb.) amelyek az örökbefogadó az örökbefogadottra és utóbbinak törvényes képviselője az örökbefogadóra (atyai hatalom, gyámság) átruházott. Az örökbefogadás joghatásait illetően a törvény a névátruházást szabályozta elsőként, mely szerint az örökbefogadó családi vagy az örökbefogadó nő születési családneve ruházható át az örökbefogadottra. ${ }^{46}$ Közös gyermekké fogadás esetén a férj családi neve átruházható volt, kivéve, ha az igazságügyminiszter a közrend érdekével ellentétesnek vélte és megtagadta. A felek megállapodhattak abban, hogy az örökbefogadott az átruházott családi nevéhez saját családi nevét kapcsolja, vagy utóbbit elhagyja. Amennyiben ilyen megállapodás nem született, akkor a családi nevet saját családi nevének elhagyásával köteles volt viselni. Ha az örökbefogadó nem ruházta át saját családi nevét és erről a szerződés sem rendelkezett, akkor az örökbefogadott neve az örökbefogadás folytán nem változott. ${ }^{47} \mathrm{Ha}$ a saját családi nevéről az örökbefogadott nem nyilatkozott, akkor nem kötelezte magát arra, hogy saját családi nevét elhagyja (216. §).48 Kivétel nélkül minden levéltári örökbefogadási szerződés rendelkezik arról, hogy az örökbefogadott addig viselt családnevét hagyja

\footnotetext{
${ }^{39}$ MEsZlÉnY, Magyar Magánjog I. 697.

40 MeszlénY, Magyar Magánjog I. 700.

${ }^{41}$ MeSZlénY, Magyar Magánjog I. 700.

42 MeszlénY, Magyar Magánjog I. 700.

43 MeszlénY, Magyar Magánjog I. 698.

${ }^{44}$ MeSZLÉNY, Magyar Magánjog I. 699.

45 MNL BML IV. 1409.b. 687-1905

46 MESZlénY, Magyar Magánjog I. 699.

47 MESZlÉNY, Magyar Magánjog I. 706.

48 MESZlénY, Magyar Magánjog I. 707.
} 
el és viselje az örökbefogadó atya családnevét, melyről a magyar királyi igazságügyminisztérium kormányhatósági megerősítésében (utolsó bekezdés) is rendelkezett.

Magyar nemesség (nemesi, főnemesi cím, előnév, címer) átruházásával kapcsolatos örökbefogadási ügyletet nem lehetett létesíteni. Az örökbefogadott gyermek tartásra volt jogosult (rendes bíróság hatáskörébe tartozott), vérségi összeköttetésen alapuló minden joga fennmaradt (öröklés, tartás és nevelés iránti igénye), mivel az örökbefogadás nem szüntette meg a vérségi kapcsolatot és az ezen alapuló öröklési jogot. ${ }^{49} \mathrm{Az}$ örökbefogadó szerződésben az örökbefogadott kiskorú vérszerinti apja és törvényes képviselője nem mondhatott le mindazon kötelezettségekről, amelyek ôt mint apát terhelték, mert a természetes szülőnek a más által örökbefogadott gyermeke iránti kötelezettségei az örökbefogadás ténye dacára is fennmaradtak. Az örökbefogadás következtében azonban megszűnt az örökbefogadott vérszerinti szülőinek szülői hatalma. Ha az örökbefogadott kiskorú volt, akkor fennmaradt a vérszerinti szülő személyes érintkezési joga, melyet szerződésben is szabályozhattak (219. §).

Az örökbefogadó halála után az örökbefogadott gyermek egyenlő jogi szempont alá esett az örökbefogadó leszármazóival. Az örökbefogadott gyermeket a törvényes gyermekhez hasonló osztályrész illette meg az örökbefogadó szülők után, az özvegyi jog korlátozását is kérhették. Az örökbefogadott után az örökbefogadó nem örökölhetett, tehát az örökbefogadás folytán az örökbefogadó szülők után egyoldalú jog keletkezett az örökbefogadott javára (217. §). Az örökbefogadott törvényes örökösödési jogát kitagadás útján vonhatták el, ha a vérszerinti szülők az örökségből kitagadták. ${ }^{50}$ Tehát az örökbefogadott gyermeknek - a PTK 1977. évi módosításáig - kettős öröklési joga volt: vérszerinti rokonai, valamint örökbefogadói és azok rokonai után úgy, mint az örökbefogadók vérszerinti gyermeke. Ez a kettős öröklési jog azt jelentette, hogy a vérszerinti szülők hagyatéki tárgyalása során fel kellett tárni, mi az örökbefogadott eredeti (örökbefogadás előtti) neve, hol él, kiknek a gondozásában van. A vérszerinti rokonok így megismerték, hova került a gyermek és nagyon sok esetben zaklatták az örökbefogadókat, de magát a gyermeket is megkísérelték elidegeníteni örökbefogadóitól. Ezen a helyzeten lényegében segített a PTK módosítása, mert abban az esetben, ha a gyermek örökbefogadóit vérszerinti szülőiként jegyezték be az anyakönyvbe, öröklési joga az eredeti, vérszerinti szülői után megszűnt, így a származás felfedésére nem kerülhet sor. Megmaradt a kettős öröklési jog akkor, ha az örökbefogadókat nem jegyezték be az anyakönyvbe vérszerinti szülőknek (1977. évi IV. tv. 617 618. $\left.\int\right)^{51}$

1867 óta a magyar királyi igazságügyminiszter erősítette meg a szerződéseket, mely nem jelentett érvényességi feltételt, csupán tanúsította, hogy a szerződés a felek akaratából köttetett, az alaki és anyagi jogszabályoknak megfelelő liquid ügylet, mely arra is szolgált, hogy harmadik személyekkel szemben tanúsítást nyerjen az örökbefogadás tényével és a névváltozás anyakönyvi bejegyzésével. A megerősítés közrendészeti szempontból volt jelentős, mert a jogügylet azért lett megerősítve, mert joghatályos örökbefogadási ügylet keletkezett a felek között. A szerződés az igazságügyminiszteri megerősítés előtt is kötötte a feleket, attól való elállást nem tett lehetôvé. Az igazságügyminiszter akkor tagadta meg a megerősítést, ha az örökbefogadás valamely törvényes

\footnotetext{
49 MESZlÉnY, Magyar Magánjog I. 706.

${ }^{50}$ MESZlÉnY, Magyar Magánjog I. 705.

${ }^{51}$ BACsÓ, Az örökbefogadás 609-616.
} 
kelléke hiányzott, vagy ha a feleknek a körülményekből nyilvánvaló akarata nem családjogi viszony alapítására irányult.. ${ }^{52} \mathrm{~A}$ megerősítés megtagadása ellen az érintettek számára egy jogorvoslati lehetőség állt nyitva: a bírói út. ${ }^{33} \mathrm{Az}$ örökbefogadó szerződés az igazságügyminiszteri megerôsítéssel lépett hatályba, melyet az igazságügyminiszter rendeleti formában adott ki. A rendelet két fő részre tagolódott: elsőként a kormányhatósági megerősítést tartalmazta, majd a közvetítő hatóságokhoz szóló utasítást - kiskorúak esetében az árvaszékhez, nagykorúaknál pedig a törvényszékhez - hogy lássák el a szerződés példányait megerősítő záradékkal, intézkedjenek az örökbefogadás ténye, a névváltozás vagy annak a ténynek az anyakönyvbe való bejegyzéséről, hogy az örökbefogadott neve nem változott, a feleket pedig az iratok egyidejü megküldésével értesítsék (213. §). ${ }^{54} \mathrm{Az}$ örökbefogadó vagy az örökbefogadott halála után megerősített szerződés csak akkor volt hatályos, ha az egyik fél az igazságügyminiszterhez vagy más közhatósághoz megerôsités/jóváhagyás végett a meghalt fél életében bemutatta vagy erre megbízást adott. (214. \).55

A levéltári kutatásaim alkalmával három esetben találkoztam azzal, hogy az igazságügyminiszter megtagadta az örökbefogadási szerződés megerősítését. Az egyik esetben a gyermek törvénytelen származásúként volt anyakönyvezve, annak ellenére, hogy házasságban született, így házassági vélelem okán, törvényes gyermekként az örökbefogadás nem jöhetett létre. ${ }^{56}$ A másik két esetben úgy szólt az örökbefogadási szerződés, hogy az „örökbefogadó átvállalja az örökbe fogadandóval szemben mindazon jogokat, melyek az atyát a törvény szerint gyermekével szemben megilletik. Ez a rendelkezés jogilag nem állhat meg, mert ide tartozik a törvényes örökösödési jog is, az örökbefogadás az örökösödés tekintetében csak az örökbefogadott javára szolgálhat." ${ }^{57}$ Illetve emellett hiányos az egyik örökbefogadási szerződés abban a tekintetben is, hogy az „örökbefogadandó a rá átruházni szándékolt családnevet saját születési családnevéhez kapcsolva vagy ez elhagyása mellett köteles és jogosult-e a jövőre nézve viselni." ${ }_{58}$

A hazai jog a felbontható örökbefogadás mellett állt, kimondta, hogy amennyiben az örökbefogadott vagy az örökbefogadó olyan cselekményt követett el, amely miatt a szülő ivadékát vagy az ivadék szülőjét kitagadhatta vagy pedig, ha az örökbefogadott vagy az örökbefogadó az örökbefogadással járó kötelességeit szándékos magaviseletével egyébként oly súlyosan megsértette, emiatt a másik félrenézve az örökbefogadás fenntartása elviselhetetlenné vált. A sértett fél az örökbefogadási szerződés megtámadására vonatkozó szabályoknak megfelelően keresettel kérhette az örökbefogadás bírói felbontását, kivéve az örökbefogadó vagy az örökbefogadott halála után, a vétkes cselekmény megbocsátása esetén. Az örökbefogadás felbontó ítélet jogerőre emelkedésének napján szűnt meg. A bíróság az örökbefogadói szerződést hatálytalanította, az örökbefogadási jogviszonyt felbontotta azon az alapon, hogy a szerződésben álló felek egyikének szándékos magatartása a másik félre nézve annyira elviselhetetlenné vált, hogy indokolt az ártatlan felett a jogviszonytól felszabadítani. Az örökbefogadói szerződés csak olyan okból hatálytalanítható, mely az örökségből való kitagadásra is elegendő. Az örökbefogadásból eredő kötelességek súlyos

\footnotetext{
52 MESZLÉNY, Magyar Magánjog I. 700-701.

53 MeSZlÉnY, Magyar Magánjog I. 703.

${ }^{54}$ MESZLÉNY, Magyar Magánjog I. 701-702.

55 MESZLÉNY, Magyar Magánjog I. 702.

${ }^{56}$ MNL BML IV. 1409.b. II-89-1899

${ }^{57}$ MNL BML IV. 1409.b. 186-1906

58 MNL BML IV. 1409.b. 186-1906
} 
megsértésének minősült a szülő- gyermek közti viszony természetében, rendeltetésében gyökerező gyermeki kötelesség oly fokú megsértése, amelyre kölcsönös elnézés, engesztelés rendes mértékét többé alkalmazni nem lehetett. Ennek minősült még a méltatlan házasság, szökés, erkölcstelen viselkedés is. ${ }^{59}$

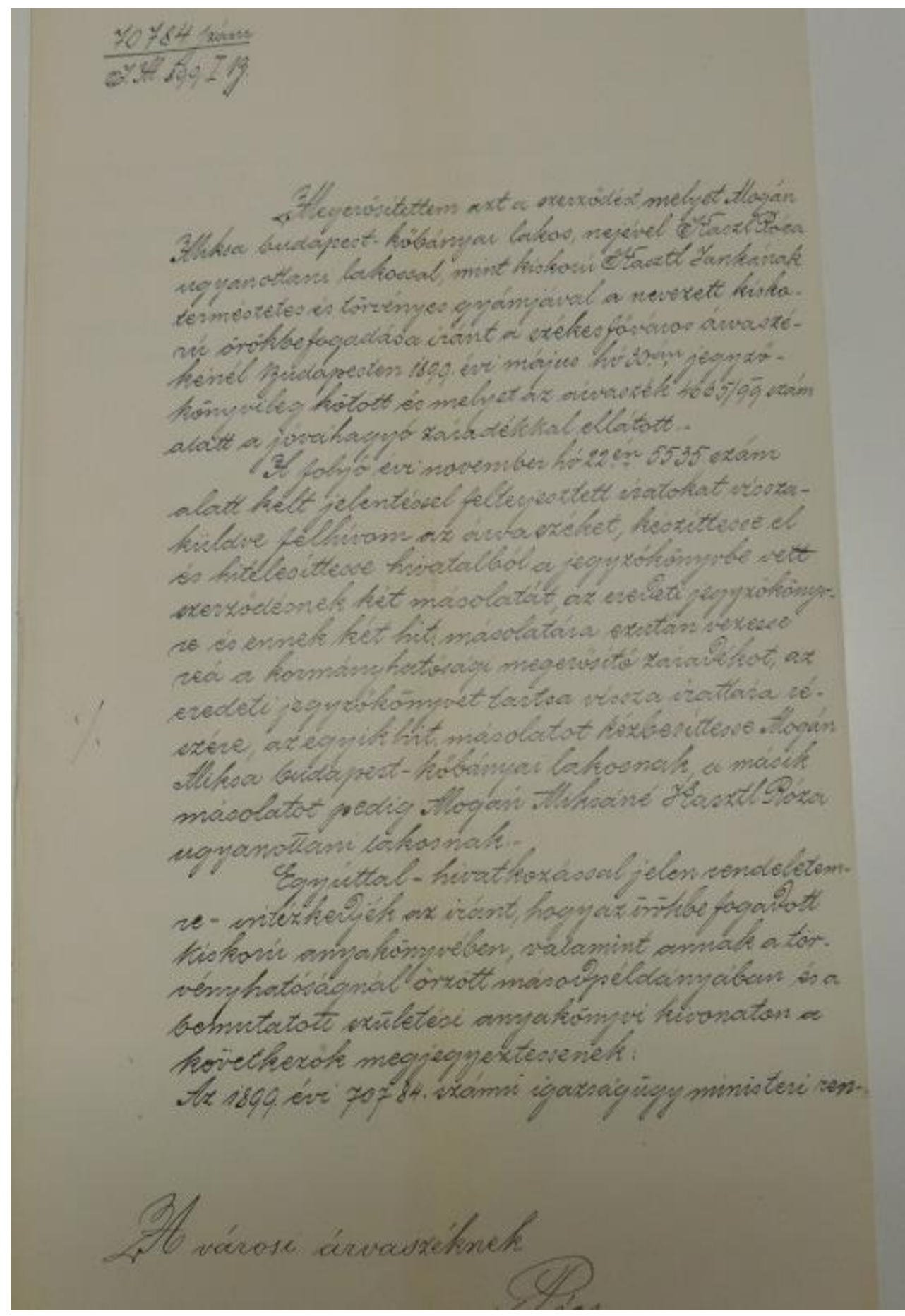

7. kép: Az örökbefogadási szerződés megerősitése a magyar királyi Igazságügyminiszter által

\footnotetext{
${ }^{59}$ MESZLÉNY, Magyar Magánjog I. 712.
} 
MNL BML IV. 1409.b. II.-617-1899 Az örökbefogadás felbontásához a törvény az igazságügyminiszter megerősítését kívánta meg. A felbontás az örökbefogadott ivadékaira akkor hatott ki, ha ahhoz ők is hozzájárultak. Közös gyermekké fogadás esetén amíg a házastársak éltek mindkét fél hozzájárulása szükséges volt a felbontáshoz. Ha a házastársak eltérő véleményen álltak a felbontást illetően, akkor az igazságügyminiszter megtagadta a megerősítést és árvaszék útján figyelmeztette a feleket, hogy a vitájukat vigyék a törvény rendes útjára (224. \$). ${ }^{60} \mathrm{Az}$ örökbefogadás megszủnése után az örökbefogadott és ivadékai nem viselhették tovább az örökbefogadó családi nevét, kivéve közös gyermekké fogadás esetét, ha az örökbefogadást az egyik házastárs halála után szerződéssel bontották fel (226. §). ${ }^{61}$

\section{A nemzetközi örökbefogadás szabályozása Magyarországon az 1940-es években}

Mintegy egy évtizeddel az MTJ illetve Mešlény összegzése után jelent meg Szladits Károly szerkesztésében a Magyar Magánjog c. sorozat első kötete, amely a nemzetközi örökbefogadással kapcsolatos jogvitákban adott útmutatót a jogalkalmazóknak. Kimondta, hogy az örökbefogadó hazai joga szerint kellett elbírálni az örökbefogadás megengedhetőségét, anyagi feltételeit, joghatásait. Az örökbefogadott korát, cselekvőképességét; az aktív örökbefogadási képességet; az örökbefogadó és az örökbefogadott egymás közti viszonyából folyó anyagi feltételeket (korkülönbség, azt, hogy szülő és törvénytelen gyermek, testvér, nagyszülő és unoka között létesülhet-e örökbefogadó szerződés), a vállalt jogok, kötelezettségek mértékét; a joghatásokat; azt, hogy a szerződés kormányhatósági megerősítésre szorul-e, az örökbefogadott hazai joga alapján bírálták el. Amennyiben a beleegyezés, jóváhagyás tekintetében az örökbefogadandó személy joga az örökbefogadó hazai jogával kollízióba került, akkor az örökbefogadandó személy hazai joga döntött az adott jogvitában. Az állami, közrendészeti szempontok nem tették kívánatossá, hogy az örökbefogadás konjukturális magánérdekeket szolgáljon, nem engedte az iparszerűséget, azt, hogy az örökbefogadó több külföldi állampolgárt örökbe fogadhasson, illetve megtagadta a megerősítést abban az esetben is, ha az örökbefogadó külföldi állampolgár volt. Kivételesen az igazságügyminiszter megerősíthette a külföldi örökbefogadó részéről kötött örökbefogadó szerződést, ha az örökbefogadó hazai állama az igazságügyminiszter intézkedését hatályosnak ismerte el; ha az örökbefogadó Magyarországon lakó, megállapíthatatlan állampolgárságú volt vagy ha a külföldi örökbefogadó hazájának törvényei szerint illetékes hatóságnál a megerősítést megkísérelte, de nem volt kieszközölhető amiatt, mert a külföldi hatóság magát a megerősítésre illetéktelennek mondta ki azért, mert az örökbefogadott külföldi, magyar honos (73. §). ${ }^{62}$

Tekintettel arra, hogy a nemzetközi örökbefogadások jelentôs része a dualizmus időszakában és a Monarchia felbomlását követően is ${ }^{63}$ színlelt jogügylet volt, mely a magyar állampolgárság megszerzésére irányult, a törvényhozó ennek tekintetében úgy rendelkezett, hogy amennyiben magyar örökbefogadó fogad örökbe külföldi gyermeket, az örökbefogadott nem szerzett magyar

\footnotetext{
60 MESZLÉNY, Magyar Magánjog I. 711.

${ }^{61}$ MESZLÉNY, Magyar Magánjog I. 713.

62 SZÁSZY, Nemzetközi magánjog, 462-464.

${ }^{63}$ Herger, A nővételtől 153.
} 
állampolgárságot, csak kedvezményes honosítás lehetôsége állt fenn. Amennyiben külföldi állampolgárságú örökbefogadó magyar gyermeket fogadott örökbe, az örökbefogadott nem vesztette el magyar állampolgárságát. Az örökbefogadó szerződés alaki érvényességét a szerződéskötés helyén és idején fennálló jog alapján, a lex loci actus kapcsolóelve szerint bírálták el (73. $\left.\int\right) \cdot{ }^{64}$

\section{5. Összegzés}

A vagyoni-öröklési jelleg az örökbefogadásból akkor tủnt el véglegesen, amikor az örökbefogadás intézményét először átfogóan szabályozta a pártállami korszak családjogi törvénykönyve 1952-ben. A CSJT-tôl az örökbefogadás egyértelmûen az elvesztett vagy hiányzó család pótlására szolgáló intézménnyé vált, amelynek célja a családi környezetet kényszerűen nélkülöző gyermekrôl való gondoskodás, az örökbefogadó részérôl pedig a gyermek utáni vágy - tehát egy érzelmi igény kielégítése. Ez a törvény szüntette meg teljes körűen a szülői felügyeleti jog átszállása nélküli adoptálást, azaz a szülői felügyelet nem maradhatott a vér szerinti szülőnél. ${ }^{65}$

A polgári társadalomban a végrendelkezési szabadság elismerése az örökbefogadás családpótló szerepét háttérbe szorította, az örökbefogadási viszony létesítését a felek megállapodására bízta, másrészt lehetővé tette nagykorú személyek örökbefogadását. Amennyiben az 1945 előtti magyar jogban az örökbefogadás gyakorlatilag alkalmasnak bizonyult a kiskorú gyermek érdekeinek biztosítására, úgy ez a házasságon kívül született gyermekek családi jogállásának bizonyos fokú rendezése terén érvényesült. Az apaság bírói megállapításának kizártsága és a törvényesítés egyéb lehetőségeinek bonyolult volta mellett az örökbefogadás révén vált lehetővé a gyermek és nemző apja közötti rokoni kapcsolat létrehozása, ezen keresztül pedig a gyermek eltartásáról való intézményes gondoskodás, ennek az utóbbi feladatnak a betöltésére az örökbefogadás természetesen csak azokban az esetekben bizonyult alkalmasnak, ahol a gyermek apjában egyébként is megvolt a gyermek felóli gondoskodásra való törekvés. ${ }^{66}$

A családnak ma is vannak olyan fontos funkció, amelyek kiegészítik mindazoknak a funkcióknak az ellátását, amelyeket az állam végez, tehát az állam és a család együttesen adja meg a biztos alapot mind ahhoz, hogy a gyermek egészséges, erkölcsös, művelt családban nôjön fel és a társadalom hasznos tagjává váljon. ${ }^{67}$

Az elmúlt évtizedek is hoztak újat az örökbefogadás társadalmi rendeltetésében: ma már az örökbefogadás elsődleges célja világviszonylatban az, hogy a családban nevelkedés biztonságát nyújtsa olyan gyermekek számára, akiknek szülei nem élnek, elhagyták őket vagy megfelelően nevelni nem képesek. ${ }^{68}$ A gyerek szempontjából az örökbefogadás előnyei a biztonságban és a pszichológiai szülőkhöz fűződő kapcsolatok folyamatosságában rejlenek. Az örökbefogadás a szülői szerep társadalmi és jogi megismerését is biztosítja. Az örökbefogadás nem utasítja el a biológiai szülők és más jelentős személyek fontosságát, biztonságot kell azonban nyújtani a gyerek

\footnotetext{
${ }^{64}$ SZÁSZY, nemzetközi magánjog 462-464.

${ }^{65}$ FÓNAGY, Az örökbefogadás https://orokbe.hu/2014/06/30/az-orokbefogadas-tortenelmi-latoszogbol

${ }^{66}$ PAP, Magyar Családi Jog, 224.; NIZSALOvSZKY, A család jogi rendjének alapjai, 293.

${ }^{67}$ BACSÓ, Az örökbefogadás 610.

${ }^{68}$ KATONÁNÉ PEHR, Az örökbefogadás 11.
} 
és örökbefogadó szülei számára, hogy a múlt eseményeit és élményeit elfogadják, megértsék és beszélhessenek azokról. ${ }^{69}$ Emellett az örökbefogadás intézménye által gyermekhez juthatnak olyan, gyermekre vágyó házaspárok, egyedülállók is, akiknek valamilyen oknál fogva nem születhet gyermekük. ${ }^{70}$

\section{Felhasznált források és irodalom}

Ideiglenes Törvénykezési Szabályok. In: MÁRKUS Dezső (szerk.): Corpus Juris Hungarici. Budapest 1896

Ausztriai általános Polgári Törvénykönyv az ezen törvénykönyvre vonatkozó, a függelékben foglalt utólagos rendeletekkel együtt, 2. hiteles kiadás, Pest 1870

Magyarország Magánjogi Törvénykönyve, a m. kir. igazságügyminiszter által 1928. március 1-én az Országgyúlés elé terjesztett törvényjavaslat. Budapest 1928

WerbŐZY István Hármaskönyve. Fordította: KOLOSvÁRI Sándor - ÓvÁRI Kelemen. In: MÁRKUS Dezső (szerk.): Corpus Juris Hungarici. Magyar Törvénytár. Budapest 1897

BACSÓ Jenő: Az örökbefogadás. Budapest 1968

BACsÓ Jenő: Az örökbefogadás. Jogtudományi Közlöny 1981/7. sz.

BÉLI Gábor: Magyar jogtörténet. Budapest - Pécs 2009

BEKE-MARTOS Judit: Az örökbefogadás - jogtörténeti megközelítésben. Családi Jog, 2009/4. sz.

CZUCZOR Gergely - FOGARASI János: A magyar nyelv szótára. Pest: Emich 1862-1874 http://mek.oszk.hu/05800/05887/cimkes.html

FÓNAGY Zoltán: Az örökbefogadás történelmi látószögből. https://orokbe.hu/2014/06/30/az-orokbefogadastortenelmi-latoszogbol

HEGEDÚs Andrea: Polgári Jog Családjog, Szeged 2014

HERGER Csabáné: A közszerzemény megosztása a paraszti népréteg körében Baranyában 1848 után. In: VARGA Norbert (szerk.): VI. szegedi jogtörténeti napok báró Eötvös József születésének 200. évfordulója alkalmából. Szeged, 2014, 67-95.

HERGER Csabáné: A nővételtől az állami anyakönyvvezetőig. A magyar házassági köteléki jog és az európai modellek. Budapest - Pécs 2006

JOBBÁGYI Gábor: Személyi és Családi Jog. Budapest 2008

KATONÁNÉ PEHR Erika: Az örökbefogadás és az örökbefogadási eljárás, Budapest 1999

KŐRÖS András (szerk.): A családjog kézikönyve I., Budapest 2007

MESZLÉNY Artúr: Magyar Magánjog I. Budapest 1931

NIZSALOVSZKY Endre: A család jogi rendjének alapjai, Budapest 1963

ORTUTAY Gyula (főszerk.): Magyar néprajzi lexikon (MNL), Budapest, 1977-1982 http://mek.oszk.hu/02100/02115/html/4-303.html

PAP Tibor: Magyar Családi Jog- Budapest 1967

SMITH, Carole R.: Örökbefogadók és nevelőszülők. Budapest 1995

SCHWAB, Dieter: Familenrecht. München 1989

SZÁSZY István: Magyar nemzetközi magánjog. In: SZLADITS Károly (szerk.): Magyar Magánjog I. Budapest 1941, 374 476.

SZỨCS LÁSZLÓNÉ SISKA Katalin: Az árvaszékek története és jogi szabályozása Szabolcs megyében 1848-1880 között. PhD értekezés, Miskolc 2000

VÉKÁs Lajos: Az osztrák Polgári Törvénykönyv hatása a magánjog fejlődésére. In: RÁCZ Lajos (szerk.): A németosztrák jogterület klasszikus magánjogi kodifikációi, Tanulmányok az OPTK és a BGB évfordulói alkalmából, Budapest 2011, 21-33.

${ }^{69}$ SMITH, Örökbefogadók és nevelőszülők 155.

${ }^{70}$ KATONÁNÉ PEHR, Az örökbefogadás 11. 
WEISS Emilia: Az örökbefogadás néhány társadalmi és jogi kérdése, Magyar Tudomány 1997/2.

ZÁмBÓ Géza: A gyámhatóságok, árvaszékek szervezete, eljárása a kiegyezés után, 2014 http://jesz.ajk.elte.hu/zambo16.html\#_ftn20 
DÁvid Gabriella

DOI: 10.15170/DIKE.2017.01.01.08

PhD-hallgató

Nemzetiségi vezető szaktanácsadó

\section{A pedagógia egyetemi tudománnyá válásának kezdetei Ausztriában és Magyarországon}

\section{The Origin of Pedagogy as an Academic Discipline in Austria-Hungary}

The basics of pedagogy as an independent discipline is provided by the ideology of the enlightment, the psychology of Wolf, developed from the ideology of the enlightment, the pedagogical features of Rousseau's works, the pedagogical movements of the time, the rapid social, economic and political changes of the late 18th century, the critical and German philosophical systems of the turn of the century. Besides the development of pedagogy, the German model, playing a dominant role from the viewpoint of the Hungarian development, can be observed on several disciplines as well. The influence of German culture on the Central-Eastern European historical region can be attributed to several reasons, such as the strong connection between Austria-Hungary and the Holy Roman Empire; Hungarian students' attendance of German universities; the inspiration of German literature, guide books, travelogues and the media.

Keywords: education, pedagogy, Ratio Educationis, science development, university

Tanulmányom a német orientációjú közép-európai pedagógiának az osztrák, majd ennek nyomán a magyar egyetemeken is megjelenő sajátos formájának létrejöttét és korai intézményesülését vizsgálja, a 18. század utolsó harmadától a 19. század elejéig tartó első fejlődési szakaszában.

A pedagógia önálló tudománnyá válásához egyrészről a felvilágosodás gondolatvilága, az abból kibontakozó $W$ olff-féle pszichológia, Rousseau mûveinek pedagógiai vonatkozásai és az azok nyomán megjelenő pedagógiai mozgalmak, továbbá a 18. század második felétől egyre jobban felgyorsuló szociális, gazdasági és politikai változások, másrészről a századforduló táján kibontakozó kritikai és az azt követő német idealista filozófiai rendszerek teremtik meg az alapokat. ${ }^{1}$ Ezeknek a széleskörű társadalmi, szellemi áramlatoknak a hatására jelent meg az igény a katolikus és protestáns teológiától elkülönülő rendszerezési törekvésekre. Így fogalmazódik meg a pedagógia, mint új tudomány, a hagyományos és új diszciplinákkal kapcsolatban álló, ugyanakkor mégis önálló karaktere.

A 20. század végére minden európai országban kialakult a neveléssel kapcsolatos tudástartalmaknak napjainkban összefoglalóan neveléstudományként definiált speciális formája. Az európai neveléstudomány fejlődésének történeti gyökereit vizsgálva megállapítható, hogy a

\footnotetext{
${ }^{1}$ MÉSZÁROS, Az iskolaügy története 616-620.
} 
kontinentális tudományfejlődésen belül már a 18. század végétől kezdődően érzékelhetô a német és osztrák felvilágosult abszolutizmusban gyökeredző, 20. század közepéig tartó külön utas fejlődés. A magyar régióban érvényesülő német dominancia folytán ez a neveléstudomány fejlődésének többi modelljétől lényegesen eltérő fejlődési modell akár sajátos közép-európai neveléstudományként is értelmezhetô. Heinz-Elmar Tenorth szerint a neveléstudománynak az a formája, amelyről most beszélünk, annak a 19. századi múvelődéspolitikának, iskolai törvényalkotási folyamatnak a szülötte, és szoros kapcsolatban állt az Oroszország, Poroszország és a k.u.k. Monarchia erőteljesen államközpontú, monarchisztikus rendszereiben létrejött szakmai professziókkal. ${ }^{2}$ A fenti folyamatok összhangban voltak a közép-európai régió egészének fejlődésével, amely társadalmi és politikai formáiban, illetve hatásaiban döntô mértékben eltért az európai művelődés, illetve államfejlődés angol liberális modelljétől, sőt - elmélettörténeti szempontból nézve - különbözött a pozitivista embertudományok fejlődésének francia modelljétől is.

A magyar fejlődés szempontjából domináns német recepció természetesen nem csupán a pedagógia tudományfejlődése kapcsán követhető nyomon. A német kultúrának a közép-európai történeti zóna egészére és ezen belül Magyarországra gyakorolt hatása számos okra vezethető vissza: például a Habsburg Monarchia és a német-római birodalom szoros kapcsolata, a magyar diákok német egyetemeken folyó tanulmányai, az ez irányból érkező irodalmi olvasmányok, útileírások, útirajzok és a sajtó hatása.

A német nevelőállam kialakulásáról tudnunk kell, hogy már 1619-ben Weimarban, aztán a német kisállamok többségében: Gothában, Württembergben bevezetik a tankötelezettséget és előbb támogatást nyújtanak az iskolafenntartóknak, aztán már előírják az iskolaállítási kötelezettséget is. I. Frigyes 1717-ben Poroszországban az állam elkerülhetetlen morális kötelességének és küldetésének tekinti az iskoláztatást. 1763-ban a poroszországi General-LandSchulreglementben, ugyanebben az évben Szászországban is, 1774-ben Bajorországban, aztán Ausztriában is megjelenik az államszintű, uralkodói rendeletekkel előírt társadalmi helyzettől függetlenül minden gyermekre kiterjedő iskolakötelezettség. A tanügyi rendeletekben a falusi tanítók végzettségére, az egyházak az iskolák felügyeleti jogára vonatkozó előírások fogalmazódnak meg, melyek az iskola valamint a település lakóinak lelki és szociális gondoskodás felügyeletét is a lelkészek hatáskörébe utalják. A század második felében fokozatosan kialakulnak a közép-európai államok tanfelügyeleti és tanügyigazgatási rendszerei.

1787-ben a porosz államminiszter, Zedlitz létrehozza az ország iskoláit felügyelő Oberschulkollegiumot, ezt a rendszert Mária Terézia és a bajor uralkodó is átveszi. A folyamat a 19. század második felében, az oktatás egészét szabályozó oktatási törvények kiadásával és ezzel párhuzamosan az első központi tantervek kialakulásával zárul. A nevelési reform kiterjedt a gazdag polgárok és a nemesek gyermekeinek korabeli magánoktatási gyakorlatára valamint a nőnevelésre és a kisgyermeknevelésre is.

Az elóbb említett törekvésekhez kapcsolódik Mária Terézia uralkodásának második szakaszában kibontakozó, a Habsburg Monarchia és Magyarországra is kiterjedő állam- illetve

\footnotetext{
${ }^{2}$ NÉMETH, Osztrák tanügyi 189-210.
} 
tanügyi reformja. ${ }^{3}$ Ennek alapelveit az uralkodó tanácsadója Josepf von Sonnelfels fogalmazza meg először 1765-ben, az államnak az iskoláztatásban betöltött szerepét hangsúlyozó „Grundsätze der Polizei und Finanz̨irtschaff' című államgazdaságtani munkájában. ${ }^{4}$ Wenzel Kaunitz kancellár tanügyi reformtervezetet jelentetett meg, az ő véleménye szerint, a gyermek nevelése és iskoláztatása a szülők természetes kötelezettsége, de mivel a művelt állampolgárok nevelése államérdek is egyben, a nevelésügy fontos állami feladatnak is tekinthető. Kaunitz így fogalmaz: „Az állam sorsa attól függ, hogy vannak-e erényes polgárai. A nemzet java része e rényessé válhat, ha a nevelés az állampolgárok különbözó osztályaihoz alkalmazkodva megadja az ifjúság számára a józan és világos fogalmakat a kötelességról, kötelességeikról." "5 Az osztrák uralkodó felvilágosult abszolutizmus programja nyomán az egész birodalomra kiterjedő, egyöntetű állami oktatási rendszert igyekezett kialakítani. Célja volt, hogy egyrészt kellő számú jól képzett hivatalnok, mérnök, orvos és más értelmiségi szakember kerüljön a megújuló államszervezet szolgálatába, másrészt, hogy az alsóbb társadalmi rétegek műveltségi színvonalának emelkedése révén mind több jól képzett munkáshoz juthasson a fejlődő ipar és kereskedelem és az egyre korszerúbb mezőgazdasági módszereket alkalmazó mezőgazdaság. Az iskoláztatás hagyományos egyházi monopóliumának felszámolása, az állami tanügyigazgatás kialakítása szintén hosszabb folyamat eredménye volt. Ekkor az osztrák örökös tartományokban a gimnáziumok a katolikus szerzetesrendek kezében voltak: jezsuiták, piaristák, bencések voltak az intézményfenntartók. A katolikus egyház ellenállása miatt nem valósul meg Johann Anton von Pergen ${ }^{6}$ 1770-1772 között kidolgozott radikális reformtervezete, amely az iskolákat - a szerzetesrendek oktatási kiváltságait megszüntetve - világi, központi állami szerv által irányított, egységes, állami oktatási rendszerbe kívánta betagolni. Az újjászervezés mérsékeltebb reformprogramját megfogalmazó természetjogász Karl Anton von Martini, Freiberr zu Wasserberg, a bécsi egyetem professzora ${ }^{7}$ minden alattvalóra kiterjedő, társadalmi helyzetével és élethivatásával összhangban álló nevelés szükségességét hangsúlyozta, amely biztosítja a növendékek jó kereszténnyé és engedelmes alattvalóvá válását.

A neveléstudomány fejlődésének kezdeteiben a nevelés jelenségeinek vizsgálata még a többi tudomány, elsősorban a teológia és filozófia szemléletmódját követte, és tartalmai elsősorban a korabeli gyakorló pedagógusok szakmai tudásához kapcsolódtak. Az 1700-as évek elején a német tanítási nyelv megjelenése után az első lépések a tanárképzésben a Lipcsei Szász Királyi Egyetemen történtek meg. A második jelentős szellemi központ a piétizmus és a német felvilágosodás szellemi központjává formálódó Hallei Egyetem. Részben ennek mintájára alapítja 1735-ben a hannoveri fejedelem a Göttingeni Egyetemet. Itt az angol szerveződési minták és a német szellemi hagyományok sajátos ötvözeteként egy újtípusú tudósközösség jött létre, mely jelentős mértékeben hozzájárult az új tudástartalmakat meghonosító tudományos iskola kialakulásához. Az oktatás színvonalát széleskörű privilégiumok is biztosították: a tanítási és tanulási szabadság, mentesülés a cenzúra alól, a kutatás-és a véleményszabadság, magas fizetés és nyugdíj, melyet az uralkodó biztosított. Ennek eredményeként a 17. század második felére a Göttingeni Egyetem a protestáns

\footnotetext{
${ }^{3}$ MÉSZÁROS, Az iskolaügy története 633-634.

${ }^{4}$ WERNER, Az osztrák büntetőjog fejlődése 143-182.

${ }^{5}$ MÉSZÁros, Az iskolaügy története 643.

${ }^{6}$ WurZBACH, Biographisches Lexikon des Kaisertums Österreich 1-4.

${ }^{7}$ WURZBACH, Martini zu Wasserberg 33-36.
} 
kultúra és egész Európa szellemi központjává vált. A Poroszországhoz tartozó Szilézia katolikus népiskoláinak korábbi sikeres átszervezését megvalósító Johann Ignaz Felbiger (1724-1788) pozsonyi prépost és fóesperes Mária Terézia felkérésére kidolgozza a népiskola átalakításának programját. A szabályzat részletesen tárgyalja az egyes iskolatípusok tananyagát, az alkalmazandó módszereket, a tankönyveket, vizsgákat, a tanévet és a tanítási szüneteket. Részletesen szól a tanulók iskolába járásának ellenőrzéséről, a tanítók jogairól és kötelességeirôl, az iskola felsőbb felügyeletéről, az iskolaépületről és felszerelésről. Elkészítette a módszer bevezetését megkönnyítő tanítói módszertankönyvét, a „Methodenbuch für Lehrer der deutschen Schulen” című tanulmányt, Bécsben, 1776-ban adták ki. A következő években megszervezte mintegy harminc tankönyv kiadását is. Felbiger intézkedései ${ }^{8}$ jelentős mértékben befolyásolják a tanítóképzés további intézményesülését, pedagógiai tartalmainak alakulását.

A rendelet alapozza meg a világi népiskolai tanító olyan egyháztól független, egységes képzésen alapuló szakmai professzióját, melynek középpontjában a pedagógia, és az oktatásmódszertan áll. Szabályozza a tanítók képzését, képesítését, alkalmazásuk feltételeit és munkájuk felügyeletét. A tanítóképzésre szolgáló normaiskola elvégzését előírja minden tanítójelölt, a tehetősebb családok házitanítói számára is. Az első normaiskola 1771-ben Bécsben nyílott meg, majd 1775-ben Pozsonyban. A tanítójelöltek, a normaiskola negyedik osztályának diákjaiként, egyrészt elsajátították a tanítás elméletét, másrészt megismerhették a normarendszer gyakorlati megvalósulását. Az 1805-ben kiadott, egészen 1848-ig érvényben maradó rendelet (Politische Verfassung der deutschen Schulen), előírja, hogy a felsőbb népiskola (Hauptschule) tanítója hat hónapos, az elemi iskola tanítója (Trivialscbule) pedig 3 hónapos tanfolyamon vegyen részt.

Az örökös tartományok tanügyi reformjával párhuzamosan 1774 januárjában vette kezdetét Ürményi Jórsef (1741-1825) országbíró vezetésével a magyar királyság területén is elkezdődött iskolaügyi reform dokumentumainak kidolgozása. 1776-ban intézkedési terv születik az állami tanügyigazgatás területi egységeinek megszervezéséről, majd 1777-ben megszületik Magyarország első állami tanügyi rendelete, a Ratio Educationis. Kettő Ratio Educationis is volt, Mária Teréziáét követte I. Ferenc 1806. évi azonos című rendelete, mely 1848-ig volt hatályban. Az eredetileg latin nyelvű rendeletek Mészáros István fordításában magyarul is olvashatók, aki a korszak oktatási reformpolitikáját is ismertette 1981-ben publikált monográfiájában. ${ }^{9}$ Ürményi tevékenységének és magának a rendeletnek a történeti jelentősége abban áll, hogy ekkor valósult meg először, hogy az állam szabályozta az oktatásügyet.

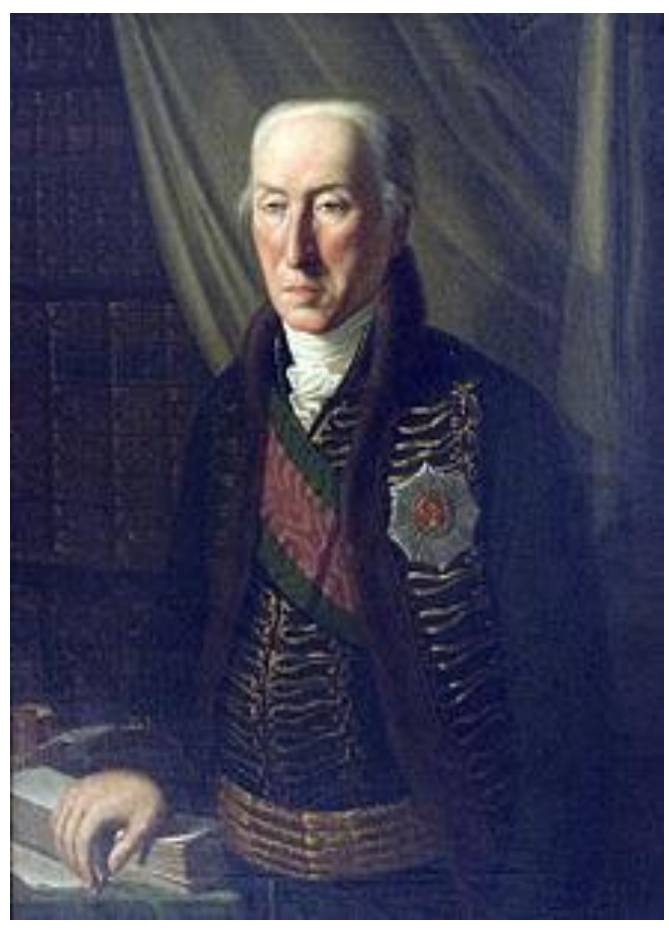

1. kép: Ürményi József (1741-1825)

\footnotetext{
8 PUKÁNSZKY - NÉMETH, Neveléstörténet http://mek.oszk.hu/01800/01893/

${ }^{9}$ MÉSZÁROS, Az iskolaügy története 632-664.
} 
Ez korábban az egyházak belügyének számított. Mindez a felvilágosult abszolutizmus gondolatvilágából következett. Az iskolák a közjót kell, hogy szolgálják és ezen az alapon az uralkodó jogot formálhat az iskolarendszer szerkezetének, a tananyag tartalmának és az oktatásban érdekeltek feladatainak meghatározására. A rendelet első abban a vonatkozásban is, hogy a teljes oktatásügyet a népiskoláktól az egyetemig egységesen rendezi. Téves az a közkeletű vélekedés, hogy a Mária Terézia-féle Ratio Educationis tankötelezettséget írt volna elő Magyarországon első alkalommal. Valójában a Népoktatási törvény volt az, amely 1868-ban kötelezővé tette 6-12 éves kor közötti gyermekek számára a népiskola látogatását. Az iskolarendszer felosztása akkoriban a következő volt: 4 év elemi, 3 év kisgimnázium, 5 év nagygimnázium és 2 év akadémia. Ezután következhetett a négyéves egyetem. A népiskolát ez a rendelet is falusi, kisvárosi és nagyvárosi iskolákra osztotta. A nagyvárosi iskolákkal kapcsolta össze a tanítóképzőket is. A leányok tanításáról külön intézkedett a rendelet, a köznép leányait vallás-és erkölcstanra, evangéliumokra, olvasásra, írásra, számvetésre, női házimunkára és Magyarország állapotának ismeretére kellett tanítani. A magasabb rangú leányoknak az említetteken kívül előírta az írók olvasását, a magyar, német, francia nyelvet, a világtörténelmet és a földrajzot.

A pedagógia ebben az időben kezdődő egyetemi tudomány rangjára emelkedése összefügg azokkal francia földön Bonaparte Napóleon császárhoz, míg a német térségben Friedrich Wilhelm Christian Carl Ferdinand von Humboldt (1767-1835) nevéhez kapcsolódó reformokkal, amelyek megteremtik a modern európai egyetem főbb típusait. (A nyelvész és államférfi Humboldt, akit elsősorban a berlini egyetem alapítójaként tisztelnek, a Magyar Tudományos Akadémia külső tagja is volt.) Az egyetemek korabeli, még középkori egyetemektől örökölt rendi jellegű, korporatív és felekezeti keretei már nem feleltek meg az ebben az időben egyre erőteljesebben érvényesülő világi szemlélet, a polgári társadalom elvárásainak. Az osztrák egyetemek állami intézménnyé válása az 1750-es években Gerhard van Swieten (1700-1772), bécsi egyetemi reformjával vette kezdetét. ${ }^{10} \mathrm{Az}$ átszervezés második szakaszában Martini (1726-1800) és Ignaz von Hess (1746-1776), reform akkori irányítói, ${ }^{11}$ a Göttingeni Egyetem szellemében kezdik el az egyetem tartalmi átalakítását. Az egyetemi professzoroktól megkövetelték, hogy jól értsenek az általuk oktatott tantárgyakhoz: teológiához, joghoz, matematikához, klasszikus nyelvekhez, de nem kívánták meg tőlük az önálló tudományos eredményeket. A magasabb tudományok igényes múvelői leginkább az uralkodók udvari tudósainak köréből kerültek ki. A tudományos érintkezés formája ebben az időben a személyes látogatás és a levelezés volt. Az újtípusú tudóstársaságok, az akadémiák és az egyetemek között még mély szakadékok húzódtak. A hagyományos egyetemi oktatók és a korszerű tudást képviselő akadémikusok között sajnos alig volt párbeszéd.

Az 1804-ben kiadott császári rendelet, mely intézkedik a pedagógia választható egyetemi tantárggyá nyilvánításáról és önálló pedagógiai tanszék megalapításáról a következőkben látja meg az új egyetemi diszciplína lényegét:

„A pedagógia a gyakorlati filozófiájának oly sok fáradozással és oly nagy haszonnal kecsegtető része, amely rászolgált arra, hogy önálló tanszék legyen." ${ }^{12}$ A bécsi egyetem neveléstani tanszéke 1808-tól múködött. A prágai és krakkói egyetemeken tanuló hallgatóknak is előírta a

\footnotetext{
10 WuRZBACH, Swieten, Gerhard Freiherr 37-50.

${ }^{11}$ BÉKÉS, A kutatóegyetem prototípusa 73-94.

12 NÉMETH, Az iskolaügy töténete 189-210.
} 
kancelláriai rendelet a heti két órában meghirdetett pedagógiai előadások egy tanéven át történő hallgatását, azok számára, akik lelkészként, valamilyen nyilvános vagy magániskola vagy gimnázium vagy főiskola filozófiai tagozatán tanárként vagy népiskolai felügyelőként vagy vezetőként vagy nevelőként hivatásszerúen foglalkozni szeretnének neveléssel-oktatással. A tantárgy oktatója rendszerint az egyetem vallástan professzora volt. A tantárgy hivatalosan előírt tankönyvének Vincent Eduard Milde munkáját határozták meg, ő volt az első katolikus teoretikus, aki a pedagógiai pszichológia megalapozására törekedett. A neveléstan oktatását egészen 1848-ig szinte kizárólag egyházi személyek végezték. Ennek elsődleges oka az volt, hogy ebben az időben ennek az értelmiségi csoportnak volt meg a megfelelő végzettsége és felkészültsége a feladat ellátásához.

Többségükben ahhoz az egyházi

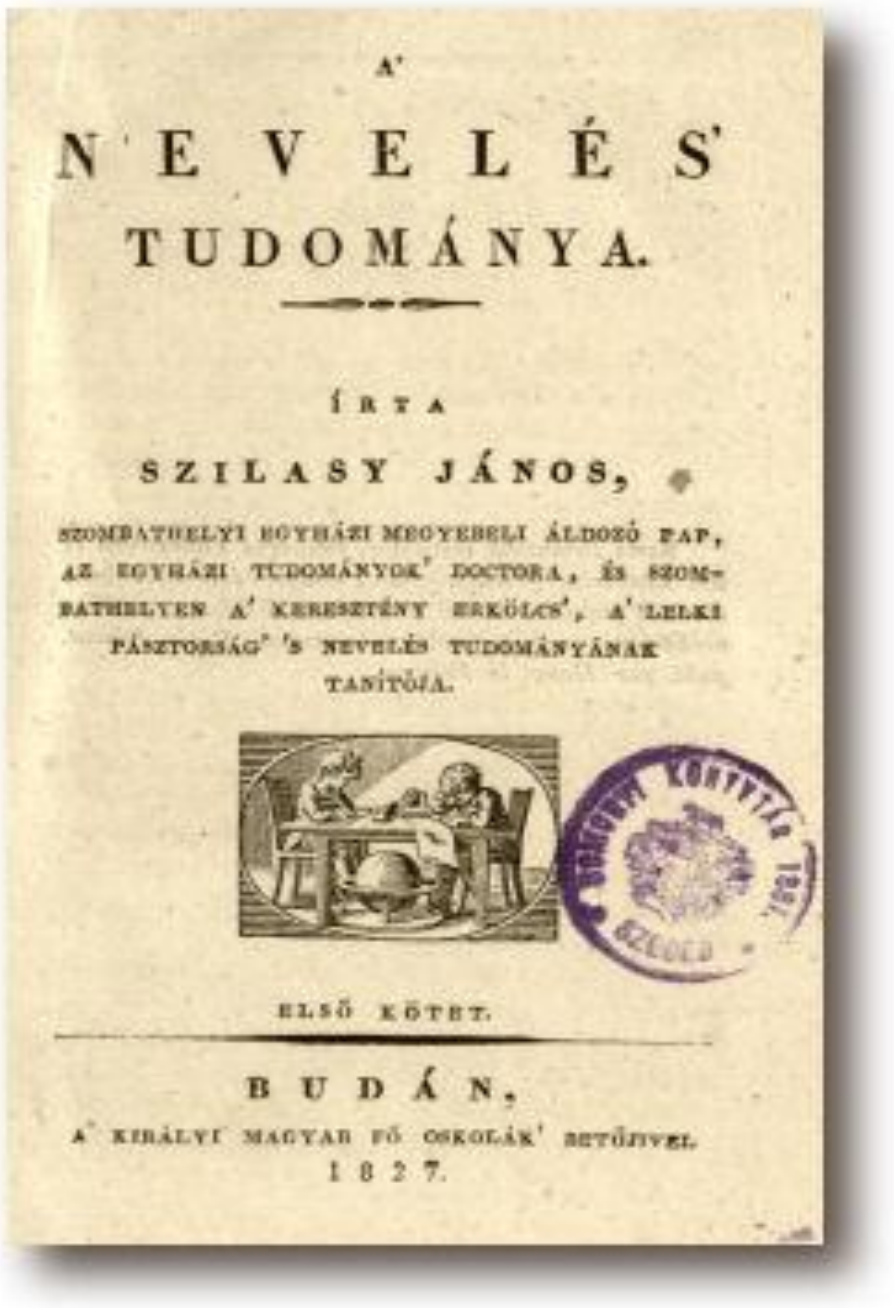
elithez tartoztak, amelynek tagjai az 1816-ban alapított Augustineum tagjaként, a bécsi egyetemen szereztek teológiából doktorátust. Az Augustineumnak célja az volt, hogy jól felkészült világi papokat képezzen, akik a papi szemináriumok tanárutánpótlását biztosították. Hasonló célokat szolgált a magyar származású papok elitképző intézete a Pázmány Péter érsek által már 1623ban alapított Pasmaneum is.

A fentiekben felvázolt fejlődési folyamat és az örökös tartományok egyetemfejlődésének közvetlen hatása jól nyomon követhető a pesti egyetemen megjelenő neveléstan oktatása kapcsán is. Ennek első lépéseként II. Józsefnek a magyarországi papnevelés átszervezésér irányuló intézkedésinek hatására 1786-ban a pesti egyetemen is elkezdődött a teológusképzés keretébe ágyazott pedagógusoktatás.

2. kép: Szilasy könyvének címlapja

A monarchia többi egyetemének gyakorlatához hasonlóan a katechetika mellett pedagógiát is oktattak, melynek tanárai Pesten Hackenfleisch Antal, Pozsonyban Pauer Károly voltak. A teológiai kar hallgatói számára 1812-ben, a bécsi minta alapján bevezetett új tanterv elôírta, hogy a magasabb neveléstan a 3. és 4. éveseknek négy külön órában kötelező lesz, amelyre nyilvános tanszék állíttatik fel, és amelyet a kinevezendő tanár ezentúl az ifjúság nevelésére készülő teológusoknak és 
világiaknak együtt adjon elő. 1822-től kötelezően előírt tankönyvek: a szintén bécsi Milde munkái voltak és Szilasy János, az első magyar nyelvű neveléstani munkája, „A nevelés tudománya” címmel. 1814-ben Krobot Jánost nevezte ki az uralkodó a Pesti Egyetem neveléstudományi professzorává. 1804-ről Stipsics E. Alajos, az éremtan rendes tanára kapott engedélyt a pedagógiai előadások tartására. A tantárgy a rendszerbe foglalt elméleti pedagógiát elkülöníti a gyakorlati nevelés és oktatástanoktól. Ezekkel a döntésekkel jöttek létre a hazai egyetemi pedagógiai oktatás szervezeti keretei és vette kezdetét a magyar egyetemi neveléstudomány fejlődésének, több mint 2000 éves előtörténete.

\section{Felhasznált források és irodalom}

Ratio Educationis. Az 1777-i és az 1806-i kiadás magyar nyelvű fordítása. Fordította, jegyzetekkel és mutatókkal ellátta: MÉSZÁros István. Budapest 1981

Ratio Educationis totiusque rei literariae per regnum Hungariae et provincias eidem adnexas. Viennae 1777

BÉKÉS Vera: A kutatóegyetem prototípusa. A XVIII. századi göttingeni egyetem. Budapest 2001

MÉSZÁROS István: Az iskolaügy története Magyarországon 996-1777 között. Budapest 1981

NÉMETH András - PUKÁNSZKY Béla: Paradigmatikus irányzatok a magyar neveléstudomány fejlődéstörténetében. Magyar pedagógia 1997/3-4. sz. 303-317.

http://www.magyarpedagogia.hu/document/Nemeth_MP9734.pdf (letöltés: 2017. október 1.)

NÉMETH András: A magyar neveléstudomány fejlődése. Budapest 2014

NÉMETH András: A pedagógia egyetemi tudomány jellegének kialakulása és intézményesülése a Pesti Egyetemen. Magyar pedagógia 2001/2. sz. 213-238.

http://www.magyarpedagogia.hu/document/Nemeth_MP1012.pdf (letöltés: 2017. október 1.)

NÉMETH András: A magyar neveléstudomány fejlődése Nemzetközi tudományfejlődés és recepciós hatások, egyetemi tudománnyá válás, középiskolai tanárképzés. Budapest 2002

http://real.mtak.hu/36276/1/2011_0001_542_06_A_magyar_nevelestudomany_fejlodestortenete\% $\% 20 \% 281 \% 29 . p d$ f (letöltés: 2017. okótber 1.)

NÉMETH András: Osztrák tanügyi reformok és a pedagógia egyetemi tudománnyá válásának kezdetei. Magyar pedagógia 2003/2. sz. 189-210.

http://www.magyarpedagogia.hu/document/Nemeth_MP1032.pdf (letöltés: 2017. október 1.)

PUKÁNSZKY Béla - NÉMETH András: Neveléstörténet. Budapest 1996

http://mek.oszk.hu/01800/01893/(letöltés: 2017. október 1.)

WERnER Ogris: Joseph von Sonnenfels és az osztrák büntetőjog fejlődése. In: HERGER Csabáné - KAJTÁR István (szerk.): Európai jogtörténészportrék I. Budapest - Pécs 2007, 143-182.

WurzBACH, Constant von: Martini zu Wasserberg, Karl Anton Freiherr von. In: Biographisches Lexikon des Kaiserthums Oesterreich. 17. Theil. Wien 1867

WurzBACH, Constant von: Swieten, Gerhard Freiherr van. In: Biographisches Lexikon des Kaiserthums Oesterreich. 41. Theil. Wien 1880 
Joghallgató, demonstrátor

PTE ÁJK

\title{
Az 1868. évi népoktatási törvény egyházi iskolákkal kapcsolatos rendelkezéseinek végrehajtása Baranyában
}

\begin{abstract}
The Implementation of the Public Education Act of 1868 in Connection with Ecclesiastic Schools in Baranya County

During the second half of the 19th century the modernization of education played a bighlighted role in Hungarian and Austrian efforts, however many debates evolved about its character, so - although significant accomplishments were achieved - mostly it divided the public opinion, generating wide ecclesiastical and social movements. In my paper I introduced the civil conversion of the 19th century, in which the modernization of public education proposed, from the aspect of the churches, comparing the Austrian and Hungarian regulation. I examined on one side the churches' contest against laicization and the efforts to protect their impact, and on the other side the opinion of the social and governmental factors, using the primary sources of the Baranya County Archives of the Hungarian National Archives.
\end{abstract}

Keywords: educational policy, state and church, secularization of church school

\section{Bevezetés}

Tanulmányomban a 19. század második felének közoktatásügyi változásait az egyházak szemszögéből vizsgálom, a magyar és az osztrák területek közötti összehasonlító jogtörténeti igénnyel, azonban a hangsúlyt az előbbire helyezve. A népoktatásra vonatkozó jogalkotási folyamatban meghatározó szerepet játszott a kétszer is vallás és közoktatásügyi miniszteri posztot betöltő Eötvös József. Gondolkodásmódjára hatással voltak a nyugati eszmék, melyeket elsődlegesen Charles de Montalambert gróffal folytatott levelezése során ismert meg. A francia politikushoz írt egyik levelében fogalmazta meg a következő sorokat, melyek egyben kutatásom mottójául is szolgálnak: „senki igazságosan nem vonhatja kétségbe azt sem, hogy a népnek nevelése s így oktatása is, minden egyház legszebb feladatai közé tartozik". Láthatjuk, hogy Eötvös szándéka nem arra irányult, hogy a közoktatás területét az egyháztól elvonja, hanem célja a modernizáció volt, továbbá a hatékonyság növelése állami közremúködés bevonásával.

A következőkben röviden ismertetem a korszak közoktatásra vonatkozó szabályozását és Eötvös szerepét a folyamatban, a dualizmus koráról lévén szó az osztrák és a magyar fejlődést összehasonlítva, majd áttérek témám lényegi részére, a gyakorlati megvalósítás ismertetésére Baranyára vonatkozóan. Arra keresek választ, hogy a magyar Országgyúlés által 1868-ban 
elfogadott népoktatási törvény végrehajtása hogyan alakult az elkövetkező évtizedekben, ehhez a Magyar Nemzeti Levéltár Baranya Megyei Levéltárának iratanyagát vizsgálom, a Baranya vármegyei főispán bizalmas és általános irataival kezdve. Hozzátenném, hogy a témámra vonatkozó korabeli iratokat még korántsem dolgoztam fel teljes mértékben, így most csupán ízelítőt kívánok adni a 19 - 20 század fordulóján fennálló helyzetről, a felszínre kerülő problémákról és a megoldási tervekről. A levéltári kutatás eredményeinek megalapozására felhasználtam 19. századi magyar szakirodalmat, országgyúlési felszólalásokat, levelezéseket, ezekkel érzékeltetve a társadalmi, egyházi és kormányzati erők véleményét, illetve a korszak törekvéseinek hullámzását. Az országos irányok alakulásának megértéséhez lényeges a helyi viszonyok és igények felmérése és értelmezése, amelyet törekszem tanulmányomban bemutatni.

\section{A népoktatási törvény közvetlen előzményei}

Az 1868-as népoktatási törvény vizsgálatához szükséges közvetlen előzményeinek ismertetése, hiszen már húsz évvel korábban is napirendre került a közoktatás modernizálásának kérdése. A 19. század közepén a magyar államférfiak felismerték, hogy a nemzet jövője szempontjából a nép művelése igen fontos szereppel bír. A fennálló közoktatásügyi állapotok jellemzése során többször hivatkoztak a felvilágosult abszolutizmus oktatási rendszerére, amikor Mária Terézia és II. József a modernizáció jegyében állami oktatási rendszer megvalósítására törekedtek. Azonban az 1800-as évekre - a korábbi uralkodók kezdeményezései ellenére - I. Ferenc császár intézkedései nyomán az intézmények jelentős része katolikus fenntartással múködött. ${ }^{1}$ A 19 . század közepéig tehát rövid megszakításokkal az egyházak, ezek között is elsősorban a római katolikus egyház befolyása érvényesült az oktatási intézmények felett. A laicizáció hatására azonban igény jelentkezett az iskolák államosítására, majd széleskörű politikai viták alakultak ki az oktatás egyházi, illetve állami jellegét illetően a liberális és a konzervatív, a világi és az egyházi erők között.

Az 1848-as modernizációs törekvések között meg kell említeni az 1848. évi XX. törvénycikket a vallás dolgában, amely megfogalmazta az iskolák állami finanszírozását, valamint az egyházi iskolák mindenki számára nyitottságát, vallásra tekintet nélkül. Ugyanebben az évben a vallás- és közoktatásügyi miniszter, Eötvös József által kidolgozott oktatási törvénytervezetben elsősorban közös, felekezeti jellegtől mentes iskolák felállitását fogalmazták meg, ugyanakkor a felekezeteket nem zárták volna el attól, hogy saját iskolákat alapítsanak és fenntartsanak. Az ekkor meghatározott irányok végrehajtásának azonban a forradalom és szabadságharc leverése, majd az elkövetkező évek politikai válsága gátat vetett, így a törvénytervezetet sem fogadták el. A magyar törekvések mégis haladónak tekinthetőek Ausztriához viszonyítva, hiszen ekkor az osztrákok részletes törvényt, illetve tervezetet nem dolgoztak ki a közoktatás kérdésében, figyelmüket a közép- és felsőoktatásra fordították.

Az osztrák és magyar fejlődés tekintetében közös pontot jelentett a Ferenc József császár és IX. Pius pápa között létrejött 1855. évi konkordátum. A sajátos nemzetközi szerződés jelentősége, hogy a római katolikus egyház pozícióját erősítette korábbi államegyházi státusza nyomán. Bár a konkordátum nem foglalkozott hosszan az iskolákkal, az ezeket érintő szakaszok hatása

\footnotetext{
${ }^{1}$ LEISCHING, Die römisch-katholische Kirche 11-13.
} 
meghatározó volt a római katolikus egyház iskolák feletti felügyelete szempontjából, melyet a püspöki kar gyakorolt. A püspököket cenzúrajog illette meg a tankönyvek tekintetében. ${ }^{2}$ A vallásoktatást kizárólag pap végezhette, de a többi tanár is egyházi felügyelet alatt vállalhatta csak a hivatalát, amely egyházi kötelezettségekkel járt. Tehát a tanárok felett minden iskolában a katolikus egyház gyakorolta a főfelügyeletet, nem csak a vallást oktatók felett. Ez csak részben volt újdonság, hiszen az iskolák és a katolikus egyház közötti - már I. Ferenc óta ténylegesen fennálló - szoros kapcsolatot törvényesen elismerték, de nem ezzel a rendelkezéssel hozták létre. ${ }^{3}$

A sajátos nemzetközi szerződés hatálya az egész Habsburg Birodalomra kiterjedt, bár a magyar jogtörténetírás kifejezetten csak osztrák konkordátumnak tekinti. ${ }^{4}$ Iskolarendszere egyike volt a fő kritikáknak, a konkordátum ellenzői az úgynevezett Konkordátum-iskolákat negatív színben tüntették fel, majd a következő évtizedekben lépéseket tettek felbontására.

\section{Az Osztrák-Magyar Monarchia népoktatási törvényei}

\section{1. Az osztrák megoldás (1868-1869)}

Az Osztrák-Magyar Monarchia létrejöttével ismét napirendre került osztrák és magyar oldalon is a népoktatás korszerűsítésének kérdése. A konkordátum felbontására, illetve az állam és az egyház viszonyának rendezésére az osztrák képviselők részéről több megoldási javaslat is érkezet, végül 1868-ban az Eduard Herbstáltal kidolgozott ún. májusi törvényeket (Maigesetze) fogadták el, amelyek közül egy kifejezetten a felekezetek és az oktatás kapcsolatáról rendelkezett. Az oktatási és nevelési ügyeket az állam legfőbb irányítása és felügyelete alá vonta, melyről az erre a célra létrehozott szervein, illetve az oktatásügyi minisztériumon keresztül volt köteles gondoskodni.

1869-ben adta ki a birodalmi népiskolai törvényt a fentiek részletezése és megerősítése érdekében az osztrák kultuszminiszter, Leopold Hasner. Célja felekezeti szempontból semleges, közös iskolák felállítása volt, ugyanakkor a vallásos nevelés szerepét is hangsúlyozták. A törvény felekezettől független iskolákat alakított ki, állami fenntartással. A tantervet a kultuszminiszter határozta meg a májusi törvények által már felállított iskolatanácsokkal egyetértésben. A vallásoktatás kötelező volt, tananyagáról az egyházi hatóságok döntöttek. Bár az iskolák felett az állami főfelügyelet érvényesült, sok helyen jelentős maradt az egyházi befolyás. ${ }^{5}$

\section{2. A magyar megoldás (1868)}

A kiegyezés után ismét a Vallás- és Közoktatásügyi Minisztérium élére kerülő Eötvös József szintén napirendre tűzte a népoktatási törvény tárgyalását. Az osztrák és a magyar politikusok hatással voltak egymás gondolkodására, ugyanakkor alapvetően eltérően rendezték a felekezetek és az oktatás kapcsolatát. Míg az osztrákok az állami iskolákat részesítették előnyben, a magyar képviselők ekkor már nem a közös iskolákat kívánták egységesen megvalósítani, hanem a felekezeti

\footnotetext{
${ }^{2}$ BALTL - KOCHER, Österreichische Rechtsgeschichte 232.

${ }^{3}$ VOCELKA, Verfassung oder Konkordat 29.

${ }^{4}$ CsIZMADIA, Rechtliche Beziehungen 68.

${ }^{5}$ LEISCHING, Die römisch-katholische Kirche 50.
} 
iskolák megtartása mellett kiegészítő jelleggel írták elő a közös iskolák létrehozását állami költségen ott, ahol nem voltak egyházi iskolák.

Eötvös kiemelte az egyház érdemét az elmúlt évszázadokban a múvelődés terjesztése kapcsán, ennek ellenére azonban úgy gondolta, hogy az nem képes egyedül ellátni a feladatot és az oktatás színvonalának emeléséhez és fenntartásához szükséges az állami szerepvállalás: „Ott, ahol a szülők vagy az egyház a gyermekek oktatásáról nem gondoskodna, az állam vállalja magára e szent kötelességet. (...) A törvény nem csak a létező felekezeti iskolákat ismeri el, hanem minden hitfelekezetnek teljes szabadságot ad új népoktatási intézetek felállítására is; a törvény a községek által közös iskolák felállítását csak ott rendeli el, hol a felekezetek a népoktatás terén feladatuknak eleget nem tesznek, azaz hol a célszerűségnek megfelelő felekezeti iskolák nem léteznek."6

A népiskolai közoktatás tárgyában elfogadott 1868. évi XXXVIII. törvény ennek megfelelően megadta a felekezetek számára a az iskolaalapítás és fenntartás szabadságát, ennek gyakorlását azonban feltételekhez kötötték, melyeket a törvény tételesen elôírt. Ilyen feltételek voltak a közegészségügyi és biztonsági szabályoknak való megfelelés, a fiúk és lányok elkülönített oktatása, a tanító által tanított gyermekek maximális számának a meghatározása.

A törvény alapján lehetőség volt már fennálló iskolákat közössé alakítani. Így közösségi iskolává minősítették azokat a felekezeti iskolákat, amelyeket községi vagyonból tartanak fenn, de a község számára meghagyták a lehetőséget, hogy továbbra is támogassa a felekezeti iskolákat; azonban ha így tesz, akkor a felekezetek között igazságosan kell megosztania a hozzájárulást. Lehetővé tették a felekezetek számára is, hogy ha ugyan fenntartható volna a felekezeti iskola, de a község különböző felekezetei úgy döntenek, hogy közösen tartanak fenn iskolát, akkor igénybe vehetnek erre állami támogatást és létrehozhatnak közös iskolát, illetve állami közös iskolává alakíthatnak meglévő felekezeti iskolát. Emellett tartalmazott rendelkezést a törvény, ha a meglévő felekezeti iskola szempontjából más vallású gyermekek száma a községben a 30-at eléri és a szülők tiltakoznak a felekezeti iskola ellen, a község köteles közös iskolát felállítani; azonban, ha számuk nem haladja meg a 30-at, akkor a gyermekek kötelesek a fennálló felekezeti iskolát látogatni.

A fent említett törvényi feltételek korántsem érvényesültek mindenütt, így különösen gyakori volt a tanító által tanítható gyermekek számának meghaladása és jellemző volt az osztályok túltömöttsége. Többen kifejezték aggályaikat a közös iskolák felállítása végrehajtásának nehézségei kapcsán, ugyanis a törvény nem fogalmazott meg felállításukra határidőt, elmulasztása esetére szankciót.7 Bár a törvény lehetőséget adott a közoktatásügyi miniszternek állami iskolák felállítására, az elkövetkező években a közoktatás kérdése háttérbe szorult, az iskolák korszerűsítésével kapcsolatban nem történt jelentős előrelépés. Az egyház ragaszkodott a felekezeti iskolákhoz még azok rossz viszonyok közötti fennállása esetén is.

\section{A 1868. évi népoktatási törvény hatása Baranyában}

A következőkben a népoktatási törvény végrehajtása kapcsán elsősorban továbbra is a felekezeti, illetve közös iskolák tekintetében elemzem az intézkedéseket, így nem térek ki a törvény egyéb

\footnotetext{
${ }^{6}$ Idézi: FELKAI, Eötvös József válogatott pedagógiai művei 207-223.

${ }^{7}$ FELKAI, Neveléstörténeti dolgozatok 111-112.
} 
rendelkezéseinek hatására. Salamon József kir. másodtanfelügyelő 1874-es jelentése alapján már érzékelhető, hogy miért is kell különbséget tennünk a végrehajtás kapcsán a községi és a felekezeti iskolák között, hiszen más iskolai hatósági rend állt az intézmények mögött. ${ }^{8}$

Az 1868-1880-as évek közötti idôszakban alapított állami iskolák száma elenyészô volt országosan is (217), Baranyában egyet sem alapítottak. 1881 és 1907 között már 5 állami iskolával rendelkezett a megye, az országban eddigre alapított 1939 iskolához képest ez azonban rendkívül alacsony volt továbbra is. ${ }^{9}$ A legtöbb állami iskola Erdélyben és a Felvidéken jött létre, ezek alapján is látható az a törekvés, hogy az iskolákat a nemzetiségek magyarosítására kívánták fordítani. A népiskolák felekezeti megoszlása a következőképpen alakult 1898-ban: római katolikus 5445, görög katolikus 2080, protestáns 3548, görög keleti 1770, izraelita 517.10

Wlassics Gyula kultuszminiszter 30 évvel a közoktatási törvény elfogadása után elérkezettnek látta az időt az iskolák állapotának felmérésére a szervezés előkészítéséhez. Baranya vármegye főispánjához, báró Fejérváry Imréhez. 1898. január 26-án írt levelében hangsúlyozta, hogy „csak oly helyeken szervezzük az állami népiskolát, a hol arra állami és kulturai szempontból valóban szükség van, és a hol a helyi viszonyok bizton remélni engedik, hogy az állami iskola életképes és virágzó leend." 11

Az iskolák létrehozását elsődlegesen a magyar nyelv oktatására és magyarosítási célokra kívánták használni, így kialakításuknál is nemzetiségi szempontokat vettek figyelembe. A görögkeleti, görög-katolikus és több evangélikus iskola a nemzetiségek számára nyújtott védelmet identitásuk megőrzésére. ${ }^{12}$ Emellett a miniszter beszámolót várt azokról a településekről, ahol a felekezetek mint iskolafenntartók nem képesek megfelelő népoktatást biztosítani. Wlassics kimutatást kért a felállítandó iskolákról, majd részletezte a hozzájárulást, amelyet azoktól a községektől várt, amelyek igényt tartanának állami iskolákra. A költségek között szerepelt az iskola elhelyezése (épület, telek), karbantartása (fütése, tisztítása), a tanítók és a hitoktatás díjazása.

A miniszter levelének utolsó bekezdése különösen fontos a felekezeti oktatás szempontjából, amelyben ígéretet tett a felekezeti arányok figyelembe vételére, amennyiben egy felekezeti iskola az állami iskolához csatlakozna: „Oly esetekben, midön valamely bitfelekęęti népiskola az illetékes egyházi föhatóság beleegyezésével - szintén csatlakozik az állami iskolához, kijelentem, hogy ily esetekben az állami iskolához. mindig az. illetö község lakosságának hiffelekezeti arányában lesznek az állami tanitók kinevezve; söt, ha az illetö bitközség kivánja, az állami tanitónak meg lesz engedve, hogy a bitközségtöl nyerendö külön dijazásért belyben és a tanórákon kivül kántori teendöket is elláthatja." ${ }^{13}$ Ebben is megnyilvánult a kompromisszumkészség a felekezetek irányába annak érdekében, hogy a népoktatást felvirágoztassák. A felmérést a főispán felszólítására az alispán és a tanfelügyelőség, illetve a pécsi polgármester végezte. Majorossy pécsi polgármester 1898. február 20-án kelt levelében beszámolt arról, hogy a város lakosságának rohamos növekedése miatt az iskolák jelentôsen túlterheltek, egy osztályba 80-100 gyerek jut, emellett a város anyagi helyzete több körülményből

\footnotetext{
${ }^{8}$ LAKI, A Pécsváradi járás iskoláinak helyzete 374.

${ }^{9}$ SZITA, A dualizmuskori iskolaállamosítási törekvések 446-447.

10 MÉSZÁROS, A katolikus iskola ezeréves története 209.

${ }^{11}$ BML MNL Főisp. biz. ir. 290/1898, 1/1898. Vkm.

${ }^{12}$ FELKAI, Neveléstörténeti dolgozatok 113.

${ }^{13}$ BML MNL Főisp. biz. ir. 290/1898, 1/1898. Vkm.
} 
adódóan leromlott és új iskolák felállítását nem engedheti meg magának. A város a levélben leírtak alapján már többször jelezte a fennálló helyzetet a Vallás- és Közoktatásügyi Minisztérium felé segélyt kérve, de a polgármestert idézve „ebbéli kérelme, az 1868. évi XXXVIII. tc világos rendelkezése dacára is mindég mereven el lett utasitva, pedig segély nélkëll sem továbbiakat épiteni, sem a tanitók fizetését rendezni, illetve korpótléknak szülkségét fedęni nem birjuk". Az állami iskolák felállítását magyar nemzeti szempontból - amire pedig nagy hangsúlyt fektettek a felmérések és a végrehajtás során indokoltnak vélte a pécsi polgármester, hiszen a Pécsett jelentős számú német és horvát lakosság gyermekeinek magyar nyelvű tanítása ehhez nagyban hozzájárult.14

$$
\text { B. bis. at. }
$$

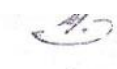

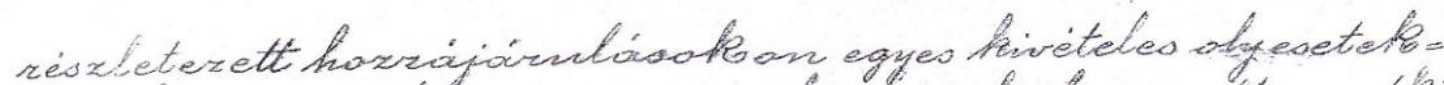

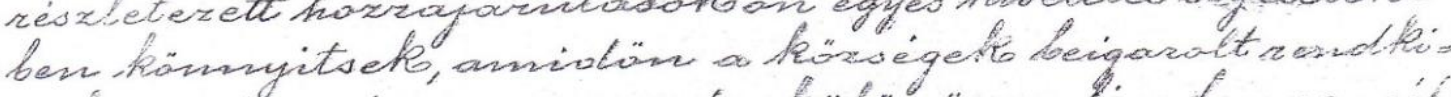
vïli ozegénysége, avagy mixo hïlönösen figyelemere mél= to terintet a fivét elt indotiolta tesii. -

$$
\text { Oly esetekber, midin valamely hitfelehereti }
$$

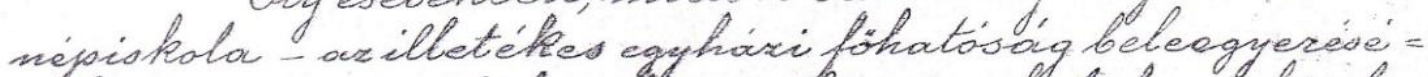

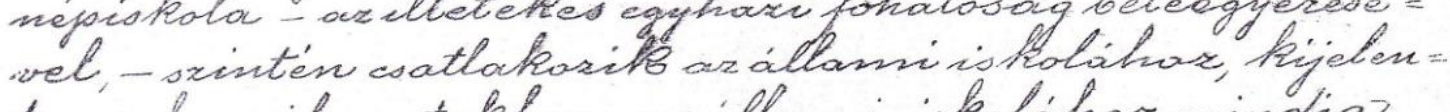
tem, hagyily esetekben ax allamis is hahar mindig.

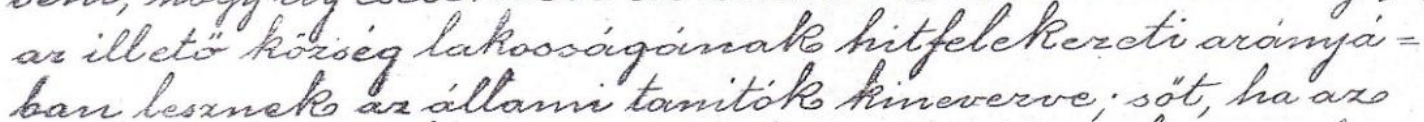
illetö hitkörség hivanja, as állowi tonitionalo meg lesz

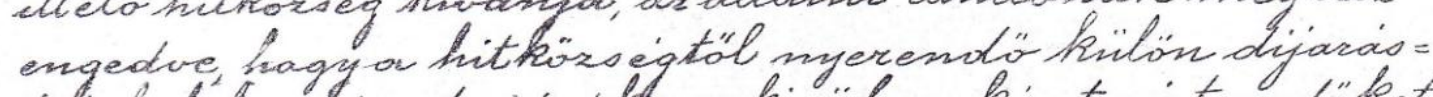

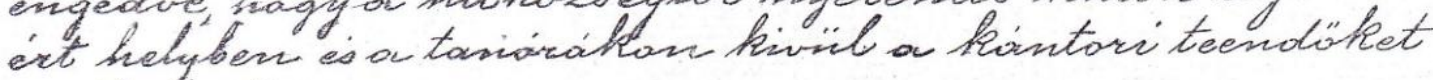

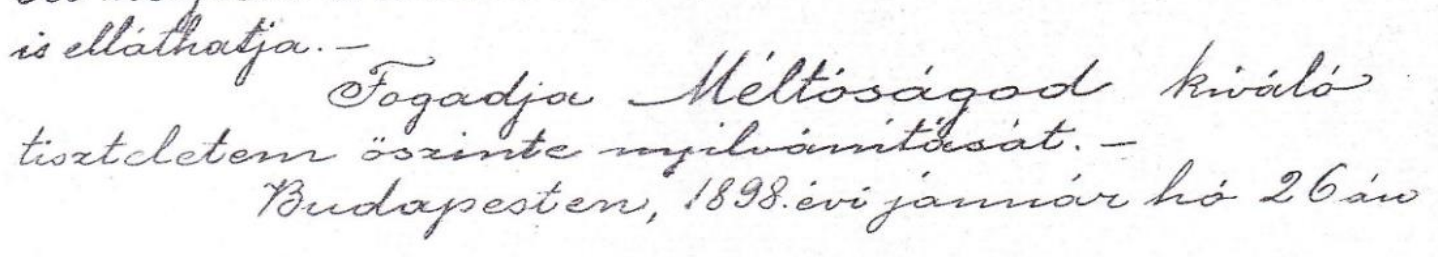

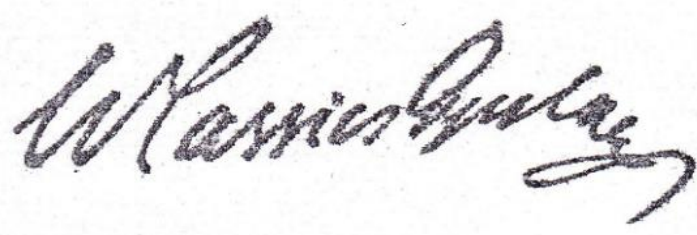

1. ábra: Wlassics Gyula levelének utolsó oldala (forrás: a szerző gyúitése)

A Vallás- és Közoktatásügyi Minisztérium a felmérés elkészítésére 2 hónap határidőt adott. Ennyi idő alatt nem sikerült elvégezni a munkát, így az elkövetkező hónapokban folyamatos

${ }^{14}$ MNL BML Főisp. biz. ir. 290/1898, 1/1898. Vkm. 
sürgetések érkeztek a minisztérium részéről (április 1., 22.) a főispánhoz, majd a főispántól (május 7., 15., 18.) a tanfelügyelőhöz és az alispánhoz.

A tanfelügyelő beszámolójában a polgármesterhez hasonlóan problémaként említette az iskolák túlzsúfoltságát, emellett a tanárok alacsony fizetését. Szintén hozzátette, hogy a város segítség nélkül nem rendelkezik elegendő forrással a megfelelő színvonalú iskolák felállításához és fenntartásához. ${ }^{15}$ Ezt követően megérkezett az alispán részletes tájékoztatása a községek helyzetérôl (1. táblázat). Ez alapján láthatjuk, hogy jelentős volt azoknak a községeknek a száma, ahol az állami iskola felállítását ellenezték. Ezzel szemben a már ismertetett pécsi állapotok miatt a pécsi járás területén támogatták a községek az állami iskola felállítását, ehhez hozzájárulni viszont nem tudtak. Több község kifejezte hozzájárulási szándékát is a felállítandó iskolákhoz, ezek mértéke változó volt, így pl. Oroszló iskolaépületét, Püspöklak a dologi kiadások fedezését, Dencsháza telket ajánlottak fel. A felmérés szólt olyan községekről, pl. Magyar-Bóly, NémetMárok, Kocska, Lipova, ahol az alispán álláspontja szerint „állami népiskola felállítása égető közszükséget képez”, de szegénységük miatt nem vállalnak semmilyen áldozatot. Ez utóbbi községekben az „égető közszükség” többnyire többségi a nemzetiségi lakosság magyarosítását jelentette, többségi német, szerb, illetve horvát lakosságú falvakról lévén szó.

\begin{tabular}{|c|c|}
\hline A település neve & Hozzájárulás \\
\hline $\begin{array}{l}\text { Drávaszentmárton, Ipacsfa, Barátúr, Marócz, Mekényes, } \\
\text { Ráczkozár, Szárász, Tófü, Nagy-Hajnás, Vázsnok, } \\
\text { Köblény, Gödre, Szent-György, Talé, Szágy, Gyümölcsény, } \\
\text { Kán, Godisa, Bisztricze, Tormás, Monostor, Kácsfalu, } \\
\text { Lipse, Virágos, Herczeg-Szent-Márton, Lőcs, Szent } \\
\text { István, Dárda, Laskafalu, Kis Dárda, Ivándárda, } \\
\text { Baranyavár, Kátoly, Szür, Óbánya,Olasz, Ófalu, Menzik, } \\
\text { Nyugat-Szent-Erzsébet, Czinderi-Bogád, Sumony, } \\
\text { Hernádfa, Rónádfa }\end{array}$ & Ellenzi az állami iskola felállítását. \\
\hline $\begin{array}{l}\text { teljes Pécsi járás, emellett: Bisse, Csarnota, Magyar-Bóly, } \\
\text { Német-Márok, Kocska, Lipova }\end{array}$ & $\begin{array}{l}\text { Örülne állami iskola felállításának, de nem tud } \\
\text { hozzájárulni. }\end{array}$ \\
\hline Lancsuk, Babarcz, Oroszló, Korpár & Iskolaépületet ajánl. \\
\hline $\begin{array}{l}\text { Almerpalkonya, Jakabfalu, Besencze, Hídvég, Czun, } \\
\text { Kásád, Egyházbér, Rodolya }\end{array}$ & $\begin{array}{l}\text { Telket, dologi kiadások fedezését, építőanyagot, egyéb } \\
\text { hozzájárulást ajánl. }\end{array}$ \\
\hline $\begin{array}{l}\text { Püspöklak, Nádasd, Pusztafalu, Kéménd, Szederkény, } \\
\text { Hidor, Nyomja, Maráza, Monyorósd, Hidas, Geresd, } \\
\text { Fazekas-Boda, Komló, Orfü, Pölöske, Jánosi, Szopók, } \\
\text { Szalatnak, Nagyágh, Tekeres, Okorvölgy, Rákos, Bános }\end{array}$ & A dologi kiadások fedezését, egyéb hozzájárulást ajánl. \\
\hline Eügenfalu, Kis-Kőszeg, Dencsháza & A dologi kiadások fedezését, telket ajánl. \\
\hline
\end{tabular}

1. táblázat: Alispáni kimutatás a községi hozzájárulásokról (forrás: a szerző összeállítása).

${ }^{15}$ MNL BML Főisp. biz. ir. 290/1898, 1536/1898. Bvm. kir. tanfelügy. 
Az adatok ismertetését követően az alispán javaslatot tett arra, hogy magyarosítási szempontok és a községek áldozatkészségét figyelembe véve mely településeken véli célszerűnek állami elemi népiskola felállítását, ezek egy csoportját 1899-re, másik részét 1900-ra ütemezve. ${ }^{16}$ Miután a fớispán felküldte a kért kimutatásokat, a Vallás- és Közoktatásügyi Minisztériumtól kevésbé bíztató válasz érkezett, amely jól tükrözi a korabeli helyzetet abból a szempontból, hogy érezték a cselekvés szükségességét, viszont a feltételek nem voltak mindenütt megfelelőek a megvalósításhoz. A miniszter a következőképpen fogalmazott: „Teljesen osztozom Méltóságod azon nézetében, mely szerint a bölcs kormányzata alatt álló vármegyének nemzetiségi viszonyai és népiskoláinak elhanyagolt állapota szüleségessé és kivánatossá teszi e vármegyében mentül több állami elemi iskola létesitését. Azonban tekintettel az ország minden részében megnyilatkozó és elodázhatatlan népoktatási sqülkségletekre a Méltoságod által felterjesztett kimutatásban felsorolt községek közül ez idô szerint csupán Babarcz, Kássád, Kéménd, Lancsuk, Lipova, Magyar-Bóly, Nádasd, Püspöklak, Szederkény, Denesháza községeket tartom oly belyeknek, a hol az állami elemi iskola sžervezése elsó sorban szüleséges (...).” Míg a megye konkrét tervvel állt elő, addig a minisztérium csupán tájékozódás szempontjából kérte fel az adatokat. A felterjesztett 127 községi iskolaállamosítási kérelem közül a miniszter csupán tíz esetben tartotta megvalósíthatónak, választását azonban nem indokolta, de községek felmérései alapján lehet következtetést levonni (2. táblázat). A legtöbb esetében nemzetiségi indokok álltak a háttérben, illetve a község hozzájárulásának mértéke vagy jellege. Ezekkel a településekkel kapcsolatban a miniszter felkérte a főispánt, hogy utasítsa a tanfelügyelőt a kijelölt községekkel a tárgyalások megkezdésére. A pécsi helyzetre tekintettel új elemi iskola felállitását állami támogatással nem helyezte kilátásba, a megoldást a város anyagi erejének fokozatos igénybevételében látta, egyúttal erre fel is szólította az illetékeseket. ${ }^{17}$

\begin{tabular}{|l|l|}
\hline \multicolumn{1}{|c|}{ A település neve } & \multicolumn{1}{|c|}{ Indokolás } \\
\hline Babarcz, Kássád & horvát lakosság többségben, iskolaépületet ajánlott \\
\hline Kéménd & német nemzetiség többségben, iskolatelket és vagyoni hozzájárulást ajánlott \\
\hline Lancsuk & szerb, német lakosság túlsúlya, iskolaépületet ajánlott \\
\hline Lipova & német és szerb többség, szegény lakosság \\
\hline Magyar-Bóly & $\begin{array}{l}\text { szerb és német nemzetiségű, három rossz állapotú iskolából egy állami iskola } \\
\text { szervezését ajánlotta }\end{array}$ \\
\hline Nádasd & vagyoni hozzájárulást ajánlott \\
\hline Püspöklak & iskolatelket és vagyoni hozzájárulást ajánlott \\
\hline Szederkény & iskolaalapját és a tanító fizetését ajánlotta \\
\hline Dencsháza & iskolatelket és a tanító fizetését ajánlotta \\
\hline
\end{tabular}

2. táblázat: Vallás- és Közoktatásügyi Minisztérium által támogatott települések (forrás: a szerző összeállítása)

${ }^{16}$ MNL BML Főisp. biz. ir. 290/1898, 10641/1898. sz. Bvm. alisp.

${ }^{17}$ MNL BML Főisp. biz. ir. 290/1898, 35114/1898 Vkm. 
Bár Wlassics kultuszminiszter előrevetítette a szükséges iskoláknak már 1899-ben való felállíthatóságát, ez nem valósult meg, ahogyan a kért tárgyalások sem vezettek eredményre. A felmérések 1906-ban folytatódtak. Az 1906-os munkálatokat a Vallás- és Közoktatásügyi Minisztérium rendelkezése alapján az alispánból, a tanfelügyelőből, járási főszolgabírókból, illetve érintett egyházi és világi személyekből álló bizottság végezte. A minisztérium - elkerülendő a korábbi tömeges jelentkezést a községek részéről - kikötötte, hogy mely esetekben nem vár javaslatot állami iskola felállítására. Ezek között szerepelt, ha az egyház ellenállására kell számtani az iskola államosítása esetén; a felekezeti iskola törvényes követelményeknek megfelel; a magyar nyelv tanítása eredményes; az iskola mérete olyan, hogy a mindennapi iskolások elhelyezhetôk; a hazafias nevelés biztosítva van; kevés a mindennapi iskolára kötelezett, de gyenge felekezeti iskola fennáll. A miniszter megadott további szempontokat is, melyekre tekintettel kellett lenni, így a nyelvi és nemzetiségi mellett a felekezeti megoszlás is figyelmet kapott a tanköteles gyermekek körében.

A felmérések során igyekeztek tekintettel lenni a felekezetekre, akik - különösen értelemszerūen a legjelentősebb pozícióval bíró római katolikus egyház - óvatosan álltak az államosításhoz és amennyire körülményeik engedték, törekedtek inkább elkerülni azt. Az elővigyázatosság nyilvánult meg a tanfelügyelőhöz intézett figyelmeztetésben, mely szerint a felekezeti iskolák érintetlenül hagyása vagy az illetékes egyházmegyei főhatóság előzetes hozzájárulása mellett kell a tárgyalásokat lefolytatni. A munkálatok során tehát igyekeztek nem csak országos, de helyi szinten is tekintettel lenni a felekezetekre. Ezt támasztja alá több járási főszolgabíró beszámolója is. Így például a Mohácsi Járás főszolgabírója reménytelen hangvételben számolt be a felekezetekkel való tárgyalásról: „a már meglévő rk. bitfelekęeti iskolák állami kezelésbe vételéhez az illetékes egyházmegyei fóhatóság hozzájárulása nem remélhetó: a szülkséges tárgyalásoknak (...) meginditását mellőstem.” A Szentlőrinci Járás hasonlóképpen vélekedett: „Bükkeösdön állami iskola felállitását célzó tervezetet nem tartom elfogadhatónak, mert ámbár tanterme 102 tanköteles gyermek befogadására nem, hanem csak. 55 befogadására alkalmas, mégis, miután felekęeti (rk.) jellegü, ki van zárva, hogy a felekezet beleegyezését adja az államositáshoz:" Ezen kívül a fószolgabíró hozzátette azt is, hogy nyelvi szempontból is szükségtelennek tartja az államosítást, hiszen bár a lakosság 2/3-a német, ők is beszélik a magyar nyelvet.

A Baranyavári Járás főszolgabírója egy olyan jelenséget is említ - nevezetesen a felekezeten kívüliséget - Várdaróccal kapcsolatban, amely a századfordulón már nem volt elhanyagolható: „Várdarócz községben (...) már számos a felekezet nélküli család, de ezeek gyermekei az iskolából kizárva nincsenek, s azt látogatják is rendesen, az iskola megfeleló, s kellö tanerövel rendelkęilk." A felekezeten kívüliek száma nôtt, és a főszolgabíró jelentése alapján számukra nem jelentett akadályt a felekezeti iskola látogatása. E település esetében az evangélikus felekezet iskolájáról volt szó, amely nem szándékozott átengedni iskoláját az állam részére. Egy másik község esetében szintén megfogalmazott a fôszolgabíró egy egyébként máshol is jellemzô tényezőt, a szülők tiltakozását az állami iskolákkal szemben: „Alberffalu községben (...) a bitfelekezet iskoláját semmi szín alatt át nem adja - sôt, az is bizonyos, hogy ha az állam mégis állitana fel állami iskolát, a szülók nem fogják gyermekeiket az. állami iskolába járatni." 
A Hegyháti és a Pécsváradi Járás fôszolgabírója arról biztosította a főispánt, hogy járásukban több község felekezeti iskolája megfelelően múködik és a többi községben állami elemi népiskola felállítását inkább nemzetiségi, mint felekezeti szempontokkal indokolták.

A Pécsi és Siklósi Járás ezzel ellentétben több helyen gyenge római katolikus, illetve görögkeleti felekezeti iskolákról számolt be, amelyek kevés sikert érnek el többek között a magyar nyelv oktatásában is a jelentős számú horvát lakosság körében. ${ }^{18}$

A jelentéseket összegyűjtve és véleményét hozzáfűzve az alispán továbbította a főispánnak. A következőkben ismét lelassultak a munkálatok. Az 1908-as állapotok alapján állami iskola alapítása vagy államosítási eljárás a közigazgatási bizottság előtt nem volt folyamatban, és mindössze 5 helyen állt már fenn, így Goricza, Komló, Kákics, Nagykozár és Oszró községekben.

\section{Következtetések}

Az osztrák és a magyar fejlődés tekintetében a közoktatás modernizációjával kapcsolatban a lényegi eltérést az jelentette, hogy míg Ausztriában elsősorban közös, állami iskolák felállítását rendelték el 1868 után, addig Magyarországon a nemzetiségi körülményekre is tekintettel az 1868-as népoktatási törvény a felekezeti iskolák meghagyása mellett kiegészítő jelleggel írta elő a közös iskolák létrehozását. Ennek megfelelően a felekezeti iskolák jelentős számban fennmaradtak. Ugyanakkor ezek sokszor alacsony színvonalon múködtek, ́́gy szükségesnek bizonyult állami elemi népiskolák felállitása, melyeket elsősorban magyarosítási célok vezéreltek. A közös állami iskola felállítására irányuló lépéseket Baranyában az 1898-as évvel kezdődően dokumentáltak. A vizsgált iratok alapján megállapítható, hogy az iskolák államosítása, illetve állami iskolák felállítása során elsősorban magyarosítási szempontokat vettek figyelembe, így a legtöbb előrelépés nemzetiségek lakta területeken történt, ahol a lakosság ilyen összetétele párosult az iskola teljes hiányával vagy a fennálló felekezeti iskola gyenge minőségével, valamint a felekezet együttmúködésre való hajlandóságával. Baranyában jelentôs volt a német, horvát, szerb lakosság, ezzel együtt is azonban kevés állami iskola felállítására került sor a 19 - 20. század fordulóján. Ennek oka részben az is, hogy a felekezeti iskolák nyelvi és nemzetiségi különbségekre tekintet nélkül adták meg híveiknek a vallásos nevelést és az alapvetô oktatást. Ez azonban nem minden esetben bizonyult elégségesnek, továbbá a nemzetiségpolitikával sem feltétlenül találkozott. A levéltári iratok alapján tudjuk, hogy a szervezési munkálatok több-kevesebb sikerrel a 20. század kezdetén folytatódtak, a jövőben szeretném feltárni ezek alapján a folyamat további lépéseit.

\section{Felhasznált irodalom}

BALTL, Hermann - KOCHER, Gernot: Österreichische Rechtsgeschichte von den Anfangen bis zur Gegenwart. Graz 2008

CSIZMADIA Andor: Rechtliche Beziehungen von Staat und Kirche in Ungarn vor 1944. Budapest 1971

FELKAI László: Eötvös József válogatott pedagógiai művei. Budapest 1957

FELKAI László: Neveléstörténeti dolgozatok a dualizmus koráról. Budapest 1983

${ }^{18}$ MNL BML Főisp. ált. ir. 14/1907, Főszolgabírói jelentések 
LAKI János: A Pécsváradi Járás iskoláinak helyzete 1874-ben Salamon József kir. másodtanfelügyelő jelentése alapján. In: Baranyai helytörténetírás. A Baranya Megyei Levéltár évkönyve. Pécs 1979

LeISCHING, Peter: Die römisch-katholische Kirche in Cisleithanien. In: WandruszKA, Adam, UrBanitsCH, Peter (szerk.): Die Habsburgermonarchie 1848-1918, Band IV: Die Konfessionen. Wien 1985

MÉSZÁROS István: A katolikus iskola ezeréves története Magyarországon. Budapest 2000

SZITA László: A dualizmuskori iskolaállamosítási törekvések nemzetiségpolitikai vonatkozásai Baranyában. In: Baranyai helytörténetírás. A Baranya Megyei Levéltár évkönyve. Pécs 1981

VOCELKA, Karl: Verfassung oder Konkordat. Wien 1978 
Joghallgató, demonstrátor

PTE ÁJK

\section{A Jászkun szabadság}

\section{A törvényesség helyi sajátosságai a Jászkun kerület népi kultúrájában $(1682-1876)^{1}$}

A jászkun népesség tekintélyes hagyományokat halmozott fel a 19. századra. A Jászkun kerület lakóit különleges kegyben részesítette az 1861-ben kiadott Ideiglenes Törvénykezési Szabályok 17. \-a. Magyarországon egyedülálló módon a hitvestársi és özvegyi öröklésre valamint az özvegyi jogra vonatkozóan a jogalkotó történelmi megfontolásból egy engedményt tett, amikor kimondta: „, $a$ jászkeun kerületben fennállott szabályok ott jövöre is zsinórmértékeül fognak szolgálni”. Ezzel a rövid és határozott kijelentéssel a jászkunok ôsi kiváltságaik egy részét tovább örökíthették a 19. század második felére is. Az olvasó mégis joggal teszi fel a kérdést, ugyan milyen egyedülállónak számító öröklési szokásokkal rendelkeztek a jászkunok, hogy ilyen mértékű védelemben részesültek? A választ Bánkiné Molnár Eræ̌sébet adja meg „A Jászkun szabadság” című könyvében.

A helyi autonómiával rendelkező jászok és kunok szorosan összefonódó társadalmának kovásza a szabadságtudat, amely mindenkor elválaszthatatlan volt a hovatartozás tudatától. A jászkunok erős érzelmi köteléket formáltak közösségi szinten a jobbágysorba süllyedést követő jogtipráskor, amire válaszul, mintegy ellenállásként megszületett a ,jásそłun szabadság” eszméje. A gondolat egyformán átszőtte a Jászkunság organikus - család, rokonság, komaság, különféle gazdasági célra összeállt kompániák stb. - és szervezett közösségének hétköznapi életét.

Elhamarkodott lenne elkönyvelni ezt a sokrétű múvet egy újabb, jogszokásokkal foglalkozó tanulmányként. A mondanivalója jóval több ennél. A szerző kitűnő érzékkel vezeti be az olvasót a Jászkunság örökségébe. Egészen a Német Lovagrend és a török hódoltság időszakától kezdve érlelődött a jászkunok életét behálózó szokások és jogszokások szövevénye. A szerző a jogrendszer minden részletének különös figyelmet szentel, amelynek a gyümölcseként egy átfogó képet kaphattunk az önálló etnikumú jászkunok jogi örökségéről. A nemzedékek együttélésére és konfliktusaira a jászkunok megoldása a középkori autonómiában gyökerezett, amiből az idők haladtával újabb és újabb kiváltságok váltak ki. Ezzel kapcsolatban érdemes megemlíteni az igazságszolgáltatás szerepét a Jászkunságban, amely egyedi módon alkalmazkodott a helyi viszonyokhoz. A hatóság által alkalmazott megtorlás sajátos formában jelent meg a közvéleménybüntetésekben. A lakosság erkölcsi nézeteit sértő magatartást gyakran gúnyverssel vagy éppen megszólással büntették. Érdekes módon az egyházi elöljárók felekezettől függetlenül, kötelező érvényü előirásokat alkothattak, amelyek a helyi hatóság és lakosság körében egyaránt megkérdőjelezhetetlen magatartási szabálynak számítottak. A könyvben megismerhetjük a Jászkun kerület eladása után jobbágysorba süllyedt jászkunok szokásainak és jogszokásainak továbbélését és kiteljesedését helyi jogszabályokban, amelyek a közigazgatási területen lakók számára kötelező

\footnotetext{
${ }^{1}$ BÁNKINÉ Molnár Erzsébet: A Jászkun szabadság, A törvényesség helyi sajátosságai a Jászkun kerület népi kultúrájában (1682-1876). Jogi Kultúrtörténeti, Jogi Néprajzi Kiskönyvtár 3. Szekszárd 2017234 pp.
} 
erejü jogi normákba, Statutumba lettek foglalva. Az emberi élet minőségét oly mértékben befolyásoló előírások egyediek voltak minden településen, és az évszázadokon keresztül alkalmazkodtak a közjogi körülményekhez, még a jászkun redempció, úgynevezett megváltás után sem sokat változtak az országos viszonyokhoz képest.

A jászkunok szokásait és jogszokásait kötelező erőre emelő Statutumok önmagukban nem fedik le egyszerre a Jászkunság sokszínű és gazdag társadalmi viszonyait. Ahogy a mai jogszabályokban sem térnek ki a helyi, mindennapi élet ügyes-bajos dolgaira, a Statutumokban sem találunk kielégítő magyarázatot a magánjogi viszonyokra, föld- és szőlőbirtoklás jogi alapjára vagy az erkölcsi normákra. A közösségi együttélés irányadó szokásai még így, törvényi erô nélkül is fennmaradtak a levéltári fondokban. Bánkiné Molnár Eræsébet különös társadalmi érzékenységről tett tanúságot, amikor az írott emlékeken kívül a történeti ikonográfiát, vallási tárgyú festményeket sem zárta ki a jogi kultúrtörténet forrásai közül. A szerző hosszú évek szorgalmas munkájával összegyújtötte a már-már feledésbe veszett tanácsi jegyzőkönyveket, közigazgatási iratokat és az úgy nevezett Liber Fundikat, azaz a jászkunok földkönyveit, hogy hú képet alkothassunk a Jászkunságról.

Bánkiné Molnár Erssébet olyan élénken tudta feltárni a 19. századi Jánszkunság mindennapjait, hogy szinte visszarepíti az olvasót szőlőhegyekre a legeltetô juhász rováspálcája mellé, ahol a hagyományok az emberekben éltek tovább, mindenféle hivatali instrukció nélkül. A könyv különlegességét a szerző egyedülálló megközelítése adja az egyszerű emberek mindennapi szokásai és jogszokásai tekintetében. Szinte csepp a tengerben az olyan munka, amely az interdiszciplinaritás talaján nemcsak a történelemtudomány tárházát tudta bővíteni, hanem a jogi kultúrtörténet és a jogi néprajz számára is maradandó értéket alkotott. „A Jászkun szabadság” című mû méltó módon örökíti meg a jászkun jogélet hagyományait. 